UNIVERSIDADE DE SÃO PAULO

FACULDADE DE FILOSOFIA, LETRAS E CIÊNCIAS HUMANAS

DEPARTAMENTO DE SOCIOLOGIA

PROGRAMA DE PÓS-GRADUAÇÃO EM SOCIOLOGIA

MYRIAN MATSUO

TRABALHO INFORMAL E DESEMPREGO:

DESIGUALDADES SOCIAIS

São Paulo

2009 
MYRIAN MATSUO

\section{TRABALHO INFORMAL E DESEMPREGO: DESIGUALDADES SOCIAIS}

Tese apresentada ao Programa de Pós-Graduação em Sociologia do Departamento de Sociologia da Faculdade de Filosofia, Letras e Ciências Humanas da Universidade de São Paulo para obtenção de título de Doutora em Sociologia

Orientador: Prof. Dr. Sedi Hirano

São Paulo

2009 
Para meu pai, Mitsuo Matsuo, e minha mãe, Shigeco Uyeno Matsuo, com muito amor e gratidão. 


\section{AGRADECIMENTOS}

Ao Prof. Dr. Sedi Hirano, que despertou meu interesse pela pesquisa e o ensino. Mestre e amigo de longa data, professor da graduação, orientador do mestrado e do doutorado, agradeço pela confiança que depositou em mim, pelo apoio e generosidade em todos os momentos. Sem suas palavras de estímulo e orientação, este trabalho não teria sido realizado.

Ao Prof. Dr. Iram Jacome, professor da pós-graduação e membro da banca examinadora do exame de qualificação, pelas importantes sugestões e críticas.

Ao Prof. Dr. Ricardo Musse, membro da banca examinadora do exame de qualificação, pelas contribuições importantes.

À Prof ${ }^{a}$. Dr ${ }^{a}$. Helena Hirata, por sua atenção, por sua generosidade, pela oportunidade de poder participar de seus cursos na pós-graduação e pelo incentivo.

À Fundação Jorge Duprat Figueiredo de Medicina e Segurança do Trabalho FUNDACENTRO - Ministério do Trabalho e Emprego (MTE), por ter oferecido a oportunidade para a elaboração desta tese de doutorado.

Ao Dr. Antonio Ricardo Daltrini, gerente da Coordenação de Saúde no Trabalho da FUNDACENTRO do Ministério do Trabalho e Emprego (MTE), pelo estímulo e apoio para a elaboração desta tese. 
Aos membros do Programa AQUAFORUM; aos colegas da FUNDACENTRO; ao Grupo Móvel de Fiscalização do Trabalho Portuário e Aquaviário do Ministério do Trabalho e Emprego (MTE) e a Luciane Keyme, pela contribuição em minha pesquisa.

A Maria de Lourdes, líder do Movimento Unidos dos Camelôs (MUCA) do Rio de Janeiro; a Sampaio, presidente do Sindicato dos Trabalhadores Informais de São Paulo, da Central Única dos Trabalhadores (CUT); ao Abrigo de Carroceiros "Dom Bosco" - São Paulo; e a Casa da Agricultura (CATI), órgão da Secretaria de Agricultura e Abastecimento do Governo do Estado de São Paulo, Regional Limeira, pelas contribuições importantes para a elaboração deste estudo.

A Tatiana Lotierzo, pela interlocução, pela paciência e pela dedicação no trabalho de revisão desta tese.

A Ruth Miranda Camargo Leifert; Akiko Kanazawa e Eliseth Rocanglia, pelo apoio e oportunidade de praticar o ensino, que é uma das minhas realizações.

À Dr ${ }^{\mathrm{a}}$. Claúdia Sztejnsznajd; à $\operatorname{Dr}^{\mathrm{a}}$. Ângela Contador; à $\operatorname{Dr}^{\mathrm{a}}$. Elda Hirose; à $\operatorname{Dr}^{\mathrm{a}}$. Haidêe Abujadi; a Nilza Simões e Silvia Ferreira, pela amizade e assistência fundamental.

Ao Eng $^{\circ}$. Dr. José Roberto Aragão, amigo e parceiro de vários projetos, pelo diálogo constante sobre este estudo, pelo apoio incondicional, pelo incentivo para meu desenvolvimento profissional e pessoal e pela compreensão e pela paciência nos momentos mais difíceis. 
A meu pai, Mitsuo Matsuo, e minha mãe, Shigeco Uyeno Matsuo, por tudo que me ensinam e por serem exemplos de pessoas determinadas, lutadoras, criativas e que têm amor à vida.

A meu irmão, Edson Matsuo, minha cunhada, Sofia Matsuo, e meus queridos sobrinhos, Pedro e Ângelo, pelo incentivo de sempre.

A meus primos Lídia; Judith; Sílvia; Mithy, Alberto; Paulinho; Giovanna e Guilherme pelo estímulo e apoio em todos os momentos.

A Maria Lúcia Caiado, amiga e secretária há muitos anos, por cuidar com todo carinho da família Matsuo, e pelas palavras de incentivo, coragem e fé.

A Marly Cardoso e Marcelo Urbano Ferreira, meus compadres paulistanos; membros da "família" e companheiros no movimento estudantil na USP; a Gabriela, minha afilhada; Matias e Tomás pelo apoio e atenção.

A Bernadette e Eneraldo, meus compadres cariocas, e Nara, minha afilhada, pelo carinho e incentivo.

A Thais, Leonam, Manuel e Marília, pelo estímulo para a conclusão da tese.

A Cláudia, Silvia e Marinês, amigas da turma de graduação em Ciências Sociais, pelos nossos encontros, nossas diversões, nossas conversas e nossas risadas.

Ao Daniel Junior Lima pelo incentivo e apoio nos momentos críticos. 
A Eliane Vainer Loeff, amiga de todos os momentos e parceira no trabalho.

A Ester Galli, amiga que, mesmo à distância, sempre torce por mim.

\section{In memorian:}

A Rubem Beltrão, companheiro e marido por mais de duas décadas, que partiu sem ver este trabalho concluído, pelo nosso amor; pela nossa história; pelo que aprendemos e construímos juntos. 


\section{RESUMO}

Este estudo demonstra, a partir de uma abordagem etnográfica, o processo de inserção e permanência de trabalhadores no mercado de trabalho informal; as formas de exploração, dominação e precarização do trabalho e suas conseqüências sobre as condições de saúde, trabalho e vida dos trabalhadores, a partir de quatro grupos abordados mais diretamente: os vendedores ambulantes; os catadores de materiais de reciclagem; os colhedores de laranja; e os pescadores de lagosta. A pesquisa revela as estratégias de resistência desenvolvidas pelos agentes informais no cotidiano de trabalho, bem como as formas de organização adotada por eles para tentar reverter a situação de pobreza e exploração.

O posicionamento das várias instituições sociais e políticas - em particular os sindicatos, as cooperativas e as Organizações Não-Governamentais (ONGs), os movimentos sociais e, principalmente, o Estado - frente ao contexto da economia informal, é destacado neste estudo. O objetivo principal é analisar a articulação do trabalho informal e sua importância no modo de produção capitalista. Tal entendimento possibilita combater as reais causas do desemprego, da informalidade e da desigualdade social e econômica.

Faz-se a crítica aos princípios do "empreendedorismo", da "autonomia" e do "cooperativismo" como alternativas ao desemprego. As várias formas de trabalho na informalidade, como o trabalho "autônomo"; o trabalho por conta-própria; o trabalho temporário; e o trabalho terceirizado, encobrem o caráter subordinado do trabalho informal aos setores dinâmicos da economia e, consequentemente, ao processo de acumulação capitalista. A falta de um contrato de trabalho, ou de um contrato que proteja totalmente o trabalhador, é considerada uma afronta à cidadania social. Sendo assim, o trabalhador informal deixa de ser visto como cidadão ou como sujeito de direitos. 
Esse problema se torna importante na medida em que analisamos o tipo de economia, o modelo de desenvolvimento e o papel do Estado como responsável pelas políticas públicas de educação; de saúde; de emprego; e de segurança, entre outras medidas voltadas a esse segmento da população. Pensamos num modelo de desenvolvimento em que sejam considerados os interesses sociais e a defesa do meio ambiente. A prioridade devem ser os investimentos na educação, em primeiro lugar. Com uma educação básica e fundamental de qualidade, podemos vislumbrar uma possibilidade de desenvolvimento com inclusão social. Os direitos de cidadania, nesse caso, se traduzem em ter acesso à educação, aos serviços de saúde, ao trabalho decente e à segurança, entre outras necessidades, para todos. 


\section{ABSTRACT}

This study demonstrates, through an ethnographic approach, the process of insertion and permanence of workers in the informal labor market - the forms of exploitation, domination, and precarization of work and their consequences with regard to the health, working, and living conditions of the workers - considering most directly the following four groups: street vendors, collectors of materials for recycling, orange pickers, and lobster fishermen. The study reveals the resistance strategies developed by the informal agents in their daily work routine, as well as the forms of organization that they have adopted in an attempt to overturn the situation of poverty and exploitation.

Emphasized in this study is the positioning of the various social and political institutions - particularly unions, cooperatives, non-governmental organizations (NGOs), social movements, and, mainly, the state - in the context of the informal economy. The main objective is to analyze the role of informal work and its importance in the capitalist mode of production. This understanding will allow for combatting the real causes of unemployment, informality of labor, and social and economic inequality.

A criticism is made of the principles of "entrepreneurism," "autonomy," and "cooperativism" that have been suggested as alternatives to unemployment. The various forms of informal work - such as "autonomous" work, self-employment, temporary work, and outsourced work - obfuscate the subordination of informal work to the dynamic sectors of the economy and, consequently, to the process of capitalist accumulation. The lack of a labor contract, or of a contract that completely protects the worker, is considered an affront to social citizenship. This being the case, the informal worker is not seen as a citizen or as a legal subject. 
This problem becomes increasingly important as we analyze the type of economy, the development model, and the role of the state as the agent responsible for public policies of education, healthcare, employment, and security, among other measures aimed at this segment of the population. A development model that takes into account social interests and the defense of the environment is proposed. Priority must be given to investment in education, in the first place. With quality primary education, it is possible to envision development with social inclusion. The rights of citizenship, in this case, translate into access to education, health services, decent work, and security - among other needs - for all. 
OS TRABALHADORES INFORMAIS NA CIDADE, NO CAMPO E, NO MAR 16

A CONSTRUÇÃO DESTE ESTUdO

CAPÍTULO 1: ABORDAGENS TEÓRICAS SOBRE O TRABALHO INFORMAL 25

1.1. DEBATE SOBRE O CONCEITO DE INFORMALIDADE 25

1.2. DIFERENTES ENFOQUES TEÓRICOS SOBRE TRABALHO INFORMAL 36

1.2.1. ABORDAGEM NEOLIBERAL $\quad 40$

1.2.2. ABORDAGEM ESTRUTURALISTA 46

1.2.3. ABORDAGEM MARGINALISTA $\quad 52$

1.2.4. ABORDAGEM SOlidARISTA OU DA ECONOMIA POPUlaR 62

CAPÍTULO 2: CAPITALISMO, DESIGUALDADE E DESENVOLVIMENTO

80

2.1. ESTADO E QUESTÃO SOCIAL

83

2.2. DESIGUALDADES E DESENVOLVIMENTO NO CAPITALISMO 98

2.3. CidADANIA E TRABalHO

102

CAPÍTULO 3: A PESQUISA SOBRE TRABALHADORES DESEMPREGADOS E INFORMAIS: NO MAR, NO CAMPO E NA CIDADE

3.1. O TRABALHO DE CAMPO

3.1.1. EXPERIÊNCIA NO MAR: PESCADORES DE LAGOSTA 121

3.1.2. EXPERIÊNCIA NO CAMPO: COLHEDORES DE LARANJA

3.1.3. EXPERIÊNCIA NA CIDADE: CATADORES DE MATERIAIS RECICLÁVEIS

3.2. METODOLOGIA $\quad \mathbf{1 4 2}$

3.2.1. LEVANTAMENTO DE DADOS SECUNDÁRIOS

3.2.2. ESTUDO EXPLORATÓRIO (PRÉ-TESTE DA PESQUISA)

3.2.3. PESQUiSA QUALITATIVA: TRAJETÓRIAS SOCIAIS E PROFISSIONAIS $\quad 146$

CAPÍTULO 4: TRAJETÓRIAS SOCIAIS DE TRABALHADORES DESEMPREGADOS

\begin{tabular}{lr}
\hline E INFORMAIS & 158 \\
\hline
\end{tabular}

4.1. TRAJETÓRIAS SOCIAIS E PROFISSIONAIS

$\begin{array}{ll}\text { 4.1.1. IDADE E SEXO } & 161\end{array}$

4.1.2. ORIGEM

$\begin{array}{lr}\text { 4.1.3. ESCOLARIDADE } & 165\end{array}$

4.1.4. INSERÇÃO NO MERCADO DE TRABALHO: A PRIMEIRA OCUPAÇÃO

4.1.5. OCUPAÇÕES NO MERCADO FORMAL E INFORMAL

4.1.6. MOTIVOS DE SAÍDA DA OCUPAÇÃO ANTERIOR

4.1.7. MOTIVOS DE ENTRADA NA OCUPAÇÃO ATUAL 180

4.1.8. ORGANIZAÇÃO DOS TRABALHADORES

4.1.9. IDENTIDADES E TRABALHO INFORMAL $\quad 207$

4.2. CONDIÇÃO DAS MULHERES

4.2.1. TRABALHADORAS E TRABALHADORES DO CAMPO 229 
4.2.2. CATADORAS E CATADORES 233

4.2.3. AMBULANTES $\quad 239$

4.2.4. ALGUMAS CONSIDERAÇÕES

4.3. CONDIÇÕES DE JOVENS

4.4. CONDIÇÃO DOS IDOSOS

4.5. CONDIÇÕES DE VIDA E RENDA

4.5.1. VENDEDORES AMBULANTES

4.5.2. CATADORES DE MATERIAIS RECICLÁVEIS 290

4.5.3. PESCADORES DE LAGOSTA 293

4.5.4. COLHEDORES DE LARANJA 296

CAPÍTULO 5: AS CONDIC̄ÕES DE SAÚDE E SEGURANCA NO TRABALHO INFORMAL

5.1. CONDIÇÕES DE TRABALHO

5.2. ACIDENTES E VIOLÊNCIA NO TRABALHO

5.2.1. ACIDENTES DE TRABALHO

$\begin{array}{ll}\text { 5.2.2. VIOLENCIA NO TRABALHO } & 324\end{array}$

5.3. DOENÇAS PROFISSIONAIS E SAÚDE MENTAL DOS TRABALHADORES

5.3.1. DOENÇAS PROFISSIONAIS

5.3.2. SAÚDE MENTAL NO TRABALHO

5.4. EXPECTATIVAS PARA O FUTURO 345

CONSIDERACÕES FINAIS $\quad 347$

REFERÊNCIAS BIBLIOGRÁFICAS 


\section{INTRODUÇÃO}

O objetivo principal deste estudo é analisar a articulação do trabalho informal e sua importância no modo de produção capitalista. Buscaremos compreender as relações sociais que permeiam essa forma de trabalho e também a influência do contexto político e econômico atual do Brasil sobre esse setor da economia.

A pesquisa tem os seguintes objetivos secundários: (1) analisar os relacionamentos sociais nos processos de inserção e permanência no mercado de trabalho informal; (2) perceber as formas de exploração, dominação e precarização do trabalho e suas conseqüências sobre as condições de saúde, trabalho e vida dos trabalhadores; (3) compreender as estratégias de resistência - tanto aquelas de acomodação, como as de enfrentamento (conflitos sociais) - desenvolvidas pelos agentes informais no cotidiano de trabalho, bem como as formas de organização adotadas por eles para tentar reverter a situação de pobreza e exploração; (4) verificar o posicionamento das várias instituições sociais e políticas frente ao contexto da economia informal, em particular os sindicatos e as Organizações Não-Governamentais (ONGs), os movimentos sociais e, principalmente, o Estado.

A partir da leitura da bibliografia sobre o trabalho informal, percebe-se que a maioria dos estudos diz respeito aos países periféricos, ou aos chamados "países em desenvolvimento". O tema da informalidade costuma estar relacionado, principalmente, com as questões do desemprego; da precarização no trabalho ${ }^{1}$; da flexibilização; da reestruturação produtiva; das políticas públicas de emprego e renda; da qualificação profissional; de gênero; do trabalho infantil; do trabalho familiar; da inserção dos 
deficientes físicos no trabalho; da ocupação do espaço urbano; da previdência social, da saúde e segurança no trabalho entre outros aspectos.

É importante ressaltar que, apesar de a problemática dos trabalhadores terceirizados, quarteirizados, temporários, ou trabalhadores flexíveis, com as devidas implicações para a chamada "nova informalidade" 2 , vamos priorizar neste estudo os desempregados e os trabalhadores informais que constituem os quadros da "velha informalidade". Os trabalhadores entrevistados em meu estudo, são desempregados da indústria, serviços e comércio, que procuram sobreviver do subemprego nas atividades informais, como vendedores ambulantes; catadores de materiais recicláveis; colhedores de laranja; e pescadores de lagosta.

Em primeiro lugar, esta pesquisa procura enfocar a questão dos trabalhos informais tradicionais, que pertencem à "velha informalidade": dos trabalhadores por conta-própria, dos autônomos, dos assalariados sem carteira, dos pequenos negócios e das pequenas empresas, onde muitas vezes prevalece o trabalho familiar ou o trabalho domiciliar. Estes trabalhadores, que costumam possuir menor escolaridade e menor qualificação, recebem salários baixos e estão mais expostos às condições precárias de trabalho - principalmente à falta de proteção e de cidadania plena. É de se supor que, devido à precarização, as formas de adoecimento e os acidentes de trabalho sejam diferentes daquelas constatadas para os empregados do mercado formal - por exemplo, destacamos o alto risco de violência, homicídios, acidentes de trânsito e os atropelamentos para os informais ${ }^{3}$.

Não parece excessivo pontuar que o desempregado não é necessariamente um desocupado, pois, muitas vezes, procura fazer "bicos". Também ele precisa "se virar", seja para complementar o seguro-desemprego ou, na falta deste, para desenvolver

2 LIMA, Jacob C. e Soares, Maria José Bezerra Soares. Trabalho flexível e o novo informal. Caderno CRH, 37, jul-dez 2002.

3 MATSUO, Myrian. Death from external causes - Recent evolution and the need for change of focus. OSH \& Development, $\mathrm{n}^{\circ} 8$, Swedish Association for Occupational and Environmental health \& Development (UFA) December, 2006. 
estratégias de sobrevivência do zero. Outra informação relevante é que desemprego pode perdurar por um longo período, ou se tornar permanente, obrigando o trabalhador a continuar na informalidade de maneira praticamente definitiva ${ }^{4}$. Faz-se necessário pensar programas e políticas públicas eficazes, voltadas para os trabalhadores informais das pequenas empresas e negócios, os trabalhadores autônomos, ou os que trabalham por conta própria ${ }^{5}$, em especial os que se encontram desorganizados e excluídos, como é o caso da grande maioria.

No Brasil, o Programa de Economia Solidária ${ }^{6}$ tem um importante papel para a organização destes trabalhadores. Podemos constatar, porém, que sua abrangência ainda é limitada em relação ao número de trabalhadores informais no país. Os programas de geração de emprego, tanto os desenvolvidos por iniciativa de órgãos governamentais, como sindicais, também são questionáveis.

Frente a esses contextos, ficam inúmeras indagações. Perguntamo-nos se existe de fato a possibilidade de se gerar postos de trabalho ou emprego para todos os desempregados ou trabalhadores informais. E também, se a própria existência e manutenção das agências de emprego particulares não constitui em si uma forma de alimentar a "indústria do desemprego", visto que as agências obtêm altos valores em dinheiro dos candidatos, ansiosos e esperançosos por conseguir trabalho.

Nesta perspectiva, permanece a dúvida sobre as reais possibilidades de construir uma sociedade em que todos sejam assalariados (condição salarial ${ }^{7}$ ). Também nos indagamos sobre a possibilidade de existência de um Estado que proteja a todos ou, em

4 OLIVEIRA, Luiz Paulo Jesus de (2005). A condição "provisória-permanente" dos trabalhadores informais: o caso dos trabalhadores de rua na cidade de Salvador. Dissertação de Mestrado apresentada ao Programa de Pos-Graduação em Ciências Sociais na Faculdade de Filosofia e Ciências Humanas, Universidade Federal da Bahia. 5 PRANDI, José Reginaldo (1978). O Trabalhador por conta própria sob o Capital. São Paulo: Edições Símbolo. 6 Ministério do Trabalho e Emprego (2005). ATLAS DA ECONOMIA SOLIDÁRIA NO BRASIL. Secretaria Nacional de Economia Solidária. Brasília, 2006. 7 CASTEL, Robert (1998). As metamorfoses da questão social: uma crônica do salário. Petrópolis, Editora Vozes. 
particular, sobre o modelo econômico capitalista ${ }^{8}$ como a principal causa da existência das desigualdades sociais ligadas às relações de trabalho, de renda, de educação e de condição de vida, entre outras. Por outro lado, não negamos a extrema necessidade de programas públicos de atenção ao desempregado ou ao trabalhador informal, mesmo com todas as suas limitações, na medida em que estas iniciativas apresentam alguns resultados positivos.

Entendemos que todos os problemas apresentados confirmam a necessidade de se aprofundar no conhecimento da realidade do trabalho informal, ou da economia informal no Capitalismo ${ }^{9}$, para podermos combater as reais causas do desemprego, da informalidade, da desigualdade social e da pobreza.

Em segundo lugar, este estudo procura apontar para outro problema que costuma estar presente nas discussões sobre a informalidade: será a inserção na economia informal a única saída para o desemprego e para a dificuldade de reinserção na economia formal, ou será uma alternativa, uma opção de trabalho entre outras possíveis, como defende o princípio do "empreendedorismo" e da "autonomia"

O trabalho informal pode tanto indicar uma estratégia de sobrevivência frente à perda de uma ocupação formal, quanto uma opção de vida para alguns segmentos de trabalhadores que preferem desenvolver seu próprio negócio para ganharem mais, serem seus próprios patrões e terem maior autonomia. Neste aspecto, surgem perguntas quanto a uma preferência dos trabalhadores pela formalidade ou informalidade, a rigidez ou a flexibilidade.

Os próprios significados do conceito de trabalho informal suscitam questionamentos sobre as diferentes formas de processos produtivos nos países centrais

8 CHESNAIS, François (1996). A mundialização do capital. São Paulo: Xamã Editora.

9 ESTENSSORO, Luís (2003). Capitalismo, Desigualdade e Pobreza na América Latina. Tese de Doutorado pelo Programa de Pós-Graduação do Departamento de Sociologia da Faculdade de Filosofia, Letras e Ciências Humanas (FFLCH) da Universidade de São Paulo (USP).

10 ALVES, Maria Aparecida \& TAVARES, Maria Augusta (2006). A DUPLA FACE DA INFORMALIDADE DO TRABALHO: "autonomia" ou "precarização". IN: ANTUNES, Ricardo (org). Riqueza e Miséria do Trabalho no Brasil. São Paulo: Boitempo. 
e nos países dependentes. Fazem-se necessários, portanto: uma caracterização dos trabalhadores informais e desempregados nos diferentes ramos de atividades, em países com características diversas; estudos que comparem os dados coletados no Brasil com aqueles observados para outros países em desenvolvimento; investigações sobre populações que ainda não foram estudadas, com vistas a ampliar nosso conhecimento; um banco de dados organizado sobre esse setor, do qual quase nada sabemos; e por fim, a tentativa de buscar um regime de eqüidade e de proteção ao setor por meio de políticas públicas eficazes, que englobem soluções para problemas como saúde e segurança no trabalho, precarização, pobreza, desigualdades socioeconômicas, criminalidade, injustiça e exclusão social, entre outros.

O terceiro problema diz respeito a uma associação recorrente entre trabalho informal e trabalho precário $^{11}$, quando talvez nem toda atividade informal possa ser considerada precária. A questão da precarização no trabalho tem sido tema de várias discussões e de publicações, de acordo com a realidade dos países europeus desde a década 90, quando ocorreu um forte processo de reestruturação produtiva e flexibilização do trabalho ${ }^{12}$ em diversos países. A falta de um contrato de trabalho, ou de um contrato que proteja totalmente o trabalhador, é considerada uma afronta à cidadania social, relativa à vida cotidiana: o trabalhador informal deixa de ser visto como cidadão ou como sujeito de direitos. Este problema se torna importante na medida em que analisamos o tipo de economia, o modelo de desenvolvimento e o papel do Estado $^{13}$.

11 Trabalho Precário: trabalho sem contrato de trabalho e trabalho com contrato que não garanta os direitos básicos: garantia de continuidade no recebimento de salário nos próximos meses, do direito às férias, da licença-maternidade, da licença por motivo de doença ou por acidentes de trabalho; da seguridade social, de aposentadoria, de indenização, de qualidade e segurança no trabalho, de remuneração adequada. Além da cassação desses direitos, significa impossibilidade de se associar, de se sindicalizar, de apelar à Justiça por seus direitos e de ter uma identidade social.

12 ANTUNES, Ricardo (1999). Os Sentidos do Trabalho. Ensaio sobre afirmação e a negação do trabalho. Boitempo Editorial, São Paulo.

13 CASTEL, Robert (1998). As Metamorfoses da Questão Social, uma Crônica do Salário. Petrópolis, Vozes. 
O trabalho informal é um elemento estrutural da economia no Brasil e nos países em desenvolvimento. A discussão sobre economia informal no Brasil sempre existiu, tendo resultado numa bibliografia extensa e de longa data. $\mathrm{O}$ tema foi preponderante na década de 70, com o crescimento do desemprego. O debate abordava os problemas da marginalidade ${ }^{14}$, do desenvolvimento do Capitalismo, da pobreza e da miséria. Os autores latino-americanos são considerados referências para esta discussão. Hoje o discurso dominante aborda a questão do desemprego tecnológico-estrutural, com desenvolvimento de uma "nova informalidade" em decorrência de novas formas de organização do trabalho constituídas no processo de reestruturação produtiva e na chamada globalização. Perdeu espaço, portanto, o debate sobre as formas de trabalho informal tradicionais. Fica-se com a impressão de que o problema do trabalho informal enquanto exército industrial de reserva está resolvido, ou é quase inexistente, conforme pressuposto pelas teorias marxistas ortodoxas no passado. No entanto, é necessário pontuar que essa economia informal, ou "velha informalidade" não apenas existe, como vem aumentando de maneira considerável juntamente com as novas formas de informalidade e com o aumento do desemprego.

Reconhecemos a importância da discussão sobre o desemprego, a flexibilização do trabalho, a terceirização e o trabalho temporário, entre outros. Por outro lado, é fundamental pensarmos na realidade do trabalho informal nos países periféricos e em desenvolvimento, onde prevalecem, por exemplo, milhares de trabalhadores informais tradicionais - os pequenos negociantes, os trabalhadores por conta própria e os trabalhadores domiciliares -, em conjunto com os trabalhadores informais resultantes do processo de globalização e da reestruturação produtiva. Nossa intenção é apontar para a 
importância do trabalho informal, mesmo que toda a discussão da Sociologia do Trabalho sobre a informalidade esteja atrelada ao debate do desemprego ${ }^{15}$.

Destaca-se que o desenvolvimento econômico nos países dependentes está diretamente atrelado ao funcionamento econômico nos países centrais, mas tanto os processos de trabalho, como as condições socioeconômicas possuem características específicas nos países periféricos. Para citar apenas algumas, destacamos a grande desigualdade social, a pobreza, a miséria, a exploração, a corrupção e a existência do Estado mínimo. Dessa maneira, é fundamental retomarmos autores preocupados com a realidade dos países latino-americanos 161718192021 , ou dos países em desenvolvimento, como por exemplo, o Brasil, e de procurarmos colaborar com a construção e as reflexões de uma Sociologia que se preocupa com o conhecimento sobre o trabalho informal nas suas diversas formas.

O trabalho informal é considerado como um desdobramento do excedente de mão-de-obra, com ocupações no setor não-organizado do mercado de trabalho (desemprego invisível). Isso equivale a dizer que ele se define a partir de pessoas que criam sua própria forma de trabalho como estratégia de sobrevivência ${ }^{22}$, ou como parte de formas alternativas de ocupação utilizadas pelas empresas capitalistas na produção por exemplo, o trabalho em tempo parcial ou casual, o trabalho temporário, o contrato

15 GUIMARÃES, Nadya Araújo (2002). Por uma Sociologia do Desemprego. Revista Brasileira Ciências Sociais, n. 17, nº 50, São Paulo, outubro. 16 CACCIAMALI, Maria Cristina (2000). Globalização e Processo de Informalidade. In: Economia e Sociedade. Campinas: Unicamp. I.E., $n^{\circ}$ 14, pp. 152-174, junho.

17 CACCIAMALI, Maria Cristina (2002). Princípio e Direitos Fundamentais no Trabalho na América Latina. São Paulo em Perspectiva, vol. 16, nº 2, São Paulo, Abril/Junho.

18 QUIJANO, Aníbal (1998). La Economia Popular y sus Caminos em América Latina. Lima: Mosca Azul. 19 TOKMAN, Victor E (2001). De la informalidad a la modernidad. Santiago, Oficina Internacional del Trabajo, Organización Internacional Del Trabajo. 20 GUIMARÃES, Nadya Araújo (2004). CAMINHOS CRUZADOS. Estratégias de empresas e trajetórias de trabalhadores. São Paulo: USP, Curso de PósGraduação em Sociologia: Ed. 34.

21 GUIMARÃES, Iracema Brandão (2002). Família, Mercado de Trabalho e Estratégias no Meio Urbano. Caderno CRH, Salvador, nº 37, pp. 235-252, julho/dezembro.

22 POCHMANN, Márcio( 2000). "O Excedente de mão-de-obra no Município de São Paulo”. In: CUT, Mapa do Trabalho Informal do Município de São Paulo. São Paulo, CUT, pp. 11-18. 
de prestação de serviços, além de subcontratações estabelecidas com pequenas empresas terceirizadas para a produção de bens e serviços ${ }^{23}$.

A questão central, de meu estudo, gira em torno da existência de vínculos entre os informais e o setor dinâmico da economia. Estaria o trabalho informal ligado à lógica capitalista de produção, integrando a cadeia produtiva do circuito de acumulação capitalista, ou seria ele representativo de setores marginais do processo produtivo, excluídos do movimento mais dinâmico da economia? Na verdade, este estudo defende a possibilidade de combinar as duas visões, pois os trabalhadores marginalizados na economia informal procuram se articular com os setores dinâmicos da economia e integrar a cadeia produtiva do circuito de acumulação capitalista, dependendo das oportunidades que surgem. Por outro lado, a economia informal nos apresenta setores que estão a reboque da formal e que passam a ser marginais por estarem descoladas do desenvolvimento econômico. Faz-se portanto uma crítica à visão dual da economia ${ }^{24}$, que separa os setores formais e informais entre o tradicional e o moderno e não os vê de maneira coexistente e interdependente .

As formas de resistência no trabalho informal ocorrem a partir da construção de redes sociais ${ }^{25} 26$ formadas por parentes e amigos. Os laços de solidariedade e de confiança na interação social são fundamentais para o desempenho na atividade e permanência na informalidade. Percebe-se que as ações das organizações coletivas, como por exemplo os sindicatos, são praticamente inexistentes ou possuem pouca representatividade. As ações do Estado com as políticas de emprego e obtenção de

23 ROSEMBLUTH, Guillermo ( 1994). Informalidad y Pobreza em América Latina. Revista de la CEPAL, nº 52, abril. 24 OLIVEIRA, Francisco de (2003). Crítica da razão dualista. O ornitorrinco. São Paulo: Boitempo Editorial.

25 LIMA, Jacob Carlos \& CONSERVA, Marinalva de Sousa (2006). Redes Sociais e Mercado de Trabalho: entre o Formal e o Informal. POLÌTICA e TRABALHO. Revista de Ciências Sociais, nº 24 Abril, pp. 73 - 98.

26 GUIMARÃES, Iracema Brandão (2002). Família, Mercado de Trabalho e Estratégias no Meio Urbano. Caderno CRH, Salvador, $n^{\circ}$ 37, pp. 235-252, julho/dezembro. 
renda são questionáveis, pois acabam atribuindo ao próprio trabalhador a responsabilidade pela obtenção e garantia de emprego.

A importância de se estudar o tema dos desempregados, dos sub-empregados e, principalmente, dos trabalhadores da economia informal tem a ver com o aumento no número de pessoas desempregadas ao redor do mundo e o desenvolvimento das estratégias de sobrevivência no setor informal. Segundo POCHMANN ${ }^{27}$, o excedente de mão-de-obra no mundo está em torno de 150 milhões de trabalhadores desempregados (desemprego aberto) e 850 milhões de sub-empregados. Este fenômeno, que se refere principalmente à economia nos países em desenvolvimento, torna-se hoje um problema para políticas públicas nos países centrais, devido à crescente imigração da mão-de-obra.

O interesse pelas condições de trabalho e de saúde na economia informal está diretamente relacionado com minha carreira profissional numa instituição de pesquisa ${ }^{28}$ em saúde e segurança do trabalho, vinculada ao Ministério do Trabalho e Emprego (MTE). Durante minha vivência de trabalho como pesquisadora, desenvolvi projetos de pesquisa sobre as condições de saúde e de trabalho em diversos ramos de atividades, principalmente nas indústrias de transformação, petroquímica, de transporte urbano e sobre a reabilitação profisssional de acidentados do trabalho. Também pude entrar em contato com a produção científica nas áreas de saúde e segurança do trabalho, de reabilitação profissional e de saúde mental no trabalho, entre outras, em nível nacional e internacional.

A partir dessa experiência, surgiram algumas questões que consideramos importantes. Em primeiro lugar, há poucas publicações sobre saúde e segurança do

27 POCHMANN, Márcio (2001). O Emprego na Globalização. São Paulo: Boitempo Ed. 28 FUNDACENTRO - Fundação Jorge Duprat de Figueiredo de Medicina e Segurança no Trabalho, com sede em São Paulo, além de Centros e Escritórios Regionais em diversos Estados. A Fundação foi criada em 1966, com o objetivo de desenvolver estudos e pesquisas na área de saúde e segurança dos trabalhadores. A pesquisadora atua na área de saúde e segurança no trabalho desde 1985, e como socióloga e psicóloga da Fundacentro/Ministério do Trabalho e Emprego, desde 1988. 
trabalho no setor informal da economia; além disso, percebemos a importância de verificar os aspectos socioeconômicos e políticos, bem como as relações de sociais de poder na situação de trabalho e na origem dos problemas reais dos trabalhadores.

Para ressaltar a relevância dos setores informais na economia, um relatório da Organização Internacional do Trabalho (OIT) acrescentou que, "segundo estimativas conservadoras, ocorrem no mundo cerca de 250 milhões de acidentes de trabalho e 160 milhões de doenças profissionais por ano. Só entre crianças são aproximadamente 12 milhões de acidentes de trabalho, dos quais 12 mil são fatais. Mortes e ferimentos continuam a representar uma taxa particularmente alta nos países em desenvolvimento, onde grande número de trabalhadores concentra-se em atividades primárias e de extração, como a agricultura, a pesca, o desmatamento e a mineração ${ }^{29}$ ".

A questão da economia informal envolve vários problemas relacionados ao trabalho infantil; aos jovens; aos idosos; aos trabalhadores na maturidade; às mulheres; aos deficientes físicos; aos desempregados de longa duração e aos imigrantes no mercado de trabalho, entre outros. Para complementar, não podemos esquecer da existência da economia subterrânea, em que encontramos inúmeros trabalhadores envolvidos com a criminalidade e a contravenção. Em relação à saúde e à segurança no trabalho, é dado que a maioria dos acidentes de trabalho - fatais ou não - ocorre numa taxa particularmente alta nos países em desenvolvimento, onde a presença da economia informal é significativamente superior, e onde boa parte da ocupação se dá nas atividades primárias, como extração, agricultura e pesca, entre outras.

Um aspecto importante a ser ressaltado é que os principais ramos de atividades abordados pela bibliografia são as indústrias de transformação, de construção civil, de mineração, as petroquímicas, os serviços de saúde, o sistema financeiro e as

29 Relatório da OIT apresentado no XV Congresso Mundial sobre Segurança e Saúde no Trabalho, que reuniu representantes de 74 países no período de 12 a 16 de abril de 1999, no Brasil. 
telecomunicações, entre outros. Percebe-se que são setores de maior relevância para a economia nacional e internacional, com organização sindical estruturada e, particularmente, setores cuja maioria dos trabalhadores possui vínculos empregatícios legais.

MACHADO e GOMES $^{30}$ confirmam que os desenvolvimentos tecnológicos, aliados à crescente urbanização, intensificam o trabalho em serviços urbanos realizados fora da empresa, localizando os acidentes de trabalho no espaço da rua - fato que acrescenta a violência urbana aos riscos inerentes aos processos produtivos ${ }^{31}$. Esta colocação destaca ainda mais a importância de se conhecer quem são esses trabalhadores informais que estão no espaço da rua e em que condições sociais e econômicas eles sobrevivem.

Com o processo de reestruturação produtiva, ocorreu a queda de empregos formais no setor industrial. Nesta perspectiva, nota-se o aumento de trabalhadores informais não só no espaço da rua, mas também nas grandes empresas, convivendo lado a lado com os trabalhadores formais, mas em situação de desigualdade. Destaca-se a situação de informalidade nas oficinas improvisadas nos domicílios e nas pequenas empresas que prestam serviços às grandes corporações. Em ambos os casos, há condições de trabalho precário, com maiores riscos de acidentes e doenças profissionais. Percebe-se que houve o deslocamento de maior volume da força de trabalho para o setor terciário, no qual também são encontrados vínculos atípicos de trabalho, como as terceirizações, o trabalho temporário e as prestações de serviços, entre outros.

30 MACHADO, J.M.H. e GOMEZ, C.M. (1994). Acidente de trabalho: uma expressão da violência social. Cadernos de Saúde Pública; 10 (supl.1): $74-87$. 31 Para a compreensão da violência no trabalho, verificar o estudo de: CARNEIRO, S. A. M. (2000). Trabalho e Violência: Relação de Proximidade - Violência a trabalhadores durante jornada de trabalho, na zona norte de São Paulo, em 1998. Dissertação de Mestrado apresentada ao Departamento de Saúde Ambiental da Faculdade de Saúde Pública da Universidade de São Paulo. 
RIBEIRO $^{32}$ e WÜNSCH ${ }^{33}$ destacam o crescimento desigual entre trabalhadores do setor formal e do setor informal da População Economicamente Ativa (PEA). Os autores percebem na PEA uma tendência de crescimento do trabalho urbano, em relação ao trabalho rural, e uma informalização da economia, com o aumento da massa de trabalhadores que atuam na chamada economia informal e a proliferação da subcontratação, do subempreitamento e da existência de trabalhadores avulsos.

Os autores relacionam estes fatores como prováveis causas da redução dos registros de acidentes de trabalho - que só passam a ocorrer a partir do momento em que se estipula o vínculo empregatício. Neste caso, é como se os trabalhadores informais fossem "invisíveis" ou "inexistentes", contribuindo para um sub-registro dos acidentes e das doenças no trabalho e para o desconhecimento da situação real de vida e de trabalho no setor informal. Nesse texto, vamos ressaltar a importância de se estudar os trabalhadores de atividades do setor informal, que é a parte pouco conhecida da PEA, e sobre os quais não se possui conhecimentos com grau razoável de segurança.

Para buscar entender a dimensão dessa população sobre a qual quase nada sabemos, vamos apresentar alguns dados fornecidos pelo IBGE para a população brasileira em geral, para a PEA - que compreende indivíduos com mais de dez anos de idade - e sobre a parcela ocupada da população. No censo demográfico de 2000 , a população brasileira era composta de 169.872.856 habitantes. Em 2008, a população estimada no Brasil chega a 183.652.196 $6^{34}$. Os dados do IBGE - PNAD mostram que a PEA de 2002 era de 86.055.645 indivíduos. Desse total, apenas 45,2\% contribuíam para a previdência social, isto é, 54,8\% da PEA não eram contribuintes.

32 RIBEIRO, Herval Pina (1994). O número de acidentes de trabalho no Brasil continua caindo: sonegação ou realidade? SOS - Revista da Associação Brasileira para Prevenção de Acidentes, Ano XIX, março/abril de 1994.

33 WÜNSCH FILHO, Victor (1999). Reestruturação produtiva e acidentes de trabalho no Brasil: estrutura e tendências. Caderno Saúde Pública, v. 15, nº 1, Rio de Janeiro, janeiro/março.

34 www.ibge.gov.br consulta realizada no dia 11/05/2005. 
No Brasil, como nos países em desenvolvimento de maneira geral, uma boa parte da população ocupada está inserida no trabalho do tipo tradicional e no trabalho informal e não-regulamentado. Nessa situação, encontramos relações autoritárias, prevalecendo a precarização do trabalho, a falta de segurança, a assistência médica de péssima qualidade, a pobreza, a fome e a exploração. Tanto o trabalho do tipo tradicional, quanto os trabalhos informais e não-regulamentados podem ser considerados como parte de uma zona de exclusão em relação à área de saúde e segurança no trabalho. Se isto forma um quadro perturbador para alguns, ele é considerado por outros como algo natural que faz parte da realidade brasileira, um problema de difícil resolução e, portanto, de pouca importância política e baixa relevância para a ciência.

A bibliografia internacional mostra que os trabalhadores terceirizados ou temporários ocupam atividades mais perigosas do que os demais - como as operações de manutenção de processos industriais -, ou as realizam sem as medidas de proteção requeridas para os demais trabalhadores (QUINLAN et. al.) ${ }^{35}$. Essa mesma bibliografia mostra que no setor informal, pequenas empresas de atividade irregular costumam envolver processos operacionais rudimentares, nos quais os procedimentos de segurança são precários ou inexistentes, o que pode explicar a alta taxa de acidentes do trabalho verificada entre esses trabalhadores (LOWENSON) $)^{36}$.

No Brasil, o Departamento de Segurança e Saúde no Trabalho (DSST) da Secretaria de Inspeção do Trabalho/MTE reconhece a precariedade dos dados referentes ao setor informal e a necessidade de se investigar a situação real do país - o que se tem

35 QUINLAN, M; MAYHEW, C. \& BOHLE, P. (2001). The global expansion of precarious employment, work disorganization, and consequences for occupational health: a review of recent research. International Journal of Health Services, 31: 335-413.

36 LOWENSON, R. Health Impact of Occupational Risks in the Informal Sector in Zimbabwe (1998). International Journal Environment and Occupational Health, 4 (4): 264-274. 
traduzido no esforço conjunto de algumas universidades e órgãos de informação em busca de dados sobre acidentes com trabalhadores que atuam no setor informal.

Os informais possuem uma identidade deteriorada ${ }^{37}$, em que prevalece a ambigüidade. Ao mesmo tempo em que são vistos como excluídos, marginalizados sociais, "cidadãos de segunda classe", são considerados criminosos, ilegais, contrabandistas, traficantes e perturbadores da ordem pela opinião pública. Considera-se a existência da corrupção, da espoliação de intermediários, da sonegação, da pirataria e das verdadeiras empresas capitalistas que se encontram por trás dos pequenos negócios.

Este estudo procurou ter como foco os trabalhadores autônomos e os que trabalham por conta própria. Eles permanecem na ponta de uma cadeia produtiva dedicada ao pequeno comércio e empreendimentos de alcance reduzido. A nosso entender, a grande maioria dos que se encontram no setor informal são estas pessoas de pouca qualificação que lutam por sua sobrevivência, obtêm baixos rendimentos, estão expostos às condições mais precárias de trabalho e têm sua cidadania negada.

Faz-se aqui uma crítica à tese que defende o "empreendedorismo", a autonomia. Segundo esta perspectiva, o trabalhador opta pelo trabalho por conta própria autônomo ou assalariado sem carteira - como meio de obter maior remuneração e de evitar relações autoritárias com patrões e chefias, apesar da insegurança na renda. A permanência na economia informal é vista antes como escolha e busca por prosperidade e liberdade, do que como exclusão social, dificuldade de inserção (ou reinserção) e permanência na economia formal - o que, a nosso entender, de fato acontece, seja por conta da pouca qualificação, pela baixa oferta de empregos, ou por causa das péssimas condições de trabalho. Para os defensores da idéia de "empreendedorismo", a 
importância e influência da política econômica e das políticas de emprego são minimizadas e o trabalhador é visto como responsável pelo seu próprio destino.

Esta pesquisa considera que os trabalhadores informais ${ }^{38}$ estão tão sujeitos às condições precárias e à exploração no trabalho quanto os formais, com o agravante de não possuírem quaisquer direitos. A condição de cidadania não é universal em nosso país e está associada ao modo de inserção dos indivíduos no mercado de trabalho. A ruptura do vínculo empregatício formal representa, na prática, a perda de direitos e benefícios sociais. Ao ingressar no setor informal, os trabalhadores se convertem numa espécie de "cidadãos de segunda classe", perdendo inclusive direitos garantidos pela Constituição brasileira. Este estudo defende a idéia de uma política de proteção social universal e de uma política de emprego e renda que vise ao direito de cidadania plena.

Um emprego com carteira assinada pode ser considerado por alguns trabalhadores na informalidade como a solução para sair de uma dura rotina de trabalho, marcada, por exemplo, pelo enfrentamento de jornada prolongada, a intensificação do ritmo de trabalho, os baixos salários, a ausência de férias, a falta de direito ao auxílio doença e acidentário, ao Fundo de Garantia por Tempo de Serviço, à aposentadoria e a qualquer proteção social, entre outros aspectos.

Pode-se notar que ter um trabalho com carteira assinada ainda apresenta um simbolismo muito forte, à medida que muitos se sentiriam mais prestigiados e respeitados pela sociedade caso tivessem empregos formais, existindo mesmo uma certa "ilusão" quanto às vantagens que ele poderia $\operatorname{propiciar}^{39}$. O emprego formal acaba sendo superestimado pelas garantias e direitos que são oferecidos, ao mesmo tempo em

38 Entenda-se trabalhador informal como aquele que não possui qualquer vínculo (trabalhador por conta própria e autônomo) ou possui vínculo de emprego atípico (terceirizados, quarterizados e temporários, entre outros).

39 SENA, Ana Laura. 2002. O trabalho informal nas ruas e praças de Belém: estudo sobre o comércio ambulante de produtos alimentícios. Belém: Núcleo de Altos Estudos Amazônicos (NAEA/UFPA). 
que as condições precárias e conflitos nas relações sociais entre empregador e trabalhador correm riscos de serem subestimados.

O presente estudo pretende compreender a complexidade do setor informal, a coexistência das diferentes formas de relações de trabalho, isto é, entre as "velhas" e "novas" informalidades e seus efeitos sobre as condições de saúde, vida e trabalho. O desconhecimento sobre a realidade dos trabalhadores informais por parte do poder público e dos sindicatos - que vêem sua base social escoar-se dia após dia para ocupações informais - dificulta a elaboração de propostas de políticas públicas de emprego, de saúde e de segurança no trabalho.

\section{Os trabalhadores informais na cidade, no campo e, no mar}

Nosso interesse pelo tema dos trabalhadores informais, mais especificamente pelos vendedores ambulantes, pelos camelôs e pelos catadores de materiais recicláveis, se deu a partir da elaboração de uma dissertação de mestrado sobre a reabilitação profissional de acidentados do trabalho ${ }^{40}$. Sabe-se que no período de afastamento do trabalho, inúmeros acidentados dedicam-se a outras atividades para complementar o baixo valor do auxílio doença acidentário. Para citar apenas alguns exemplos de "bicos", lembramos os camelôs, vendedores ambulantes, "flanelinhas", guardadores de carros, catadores de materiais recicláveis e doceiras. Quando retornam à empresa, os que não conseguem ser reabilitados são demitidos. Para eles, só resta inserir-se de fato 
na economia informal e permanecer definitivamente nela, pois existe pouca possibilidade de conseguirem outro emprego formal.

A falta de proteção social ao trabalhador acidentado, tanto por parte do Estado como da empresa; a necessidade de recorrer à ajuda financeira de familiares, amigos e da comunidade em geral; a falta de assistência médica e a participação na economia informal como forma de subsistência e complementação de renda do auxílio-doença ou acidentário são questões de extrema importância, ressaltadas pela literatura sobre a reabilitação dos acidentados do trabalho ${ }^{41} 4243$.

No ano de 2003, tivemos a oportunidade de apresentar um paper sobre as mortes de trabalhadores por causas externas num Congresso no exterior ${ }^{44}-\mathrm{o}_{\text {que resultou na }}$ publicação de um artigo $^{45}$ em revista internacional, em 2006. Durante a pesquisa, desenvolvida com os trabalhadores sobre as vítimas desse tipo de mortalidade, foi possível constatar que o vínculo precário é percebido como um fator de risco em si. As mortes por fatores externos - como acidentes de trânsito, atropelamentos e homicídios apresentam uma incidência maior entre os trabalhadores informais - particularmente vendedores ambulantes e camelôs. Podemos considerar que estes indivíduos, além de não possuírem qualquer proteção social e trabalhista, estão mais expostos a contextos de trabalho em que a violência e as perseguições se fazem presentes e visíveis no dia-a-dia.

Pretendemos agora compreender as relações sociais no trabalho e seus efeitos sobre a saúde e a vida de milhares de homens e mulheres que vendem todos os tipos de produto no mercado informal para sobreviver. Os locais de venda dos camelôs se estendem por ruas e praças no espaço urbano e fazem parte do que podemos denominar

41 HIRANO, Sedi et alli (1990). A cidadania do trabalhador acidentado: (re)conhecimento do direito aos direitos sociais. Tempo Social; Revista Sociol. USP, São Paulo 2(1): 127-150.

42 COHN, Amélia et alli (1985). Acidentes do Trabalho - uma forma de violência. São Paulo: CEDEC/Brasiliense.

43 COSTA, Márcia Regina da (1981). As vítimas do capital: os acidentados do trabalho. Rio de Janeiro: Achiamé.

44 27th International Congress on Occupational Health - ICOH - Foz de Iguaçu/Brasil - 2003.

45 MATSUO, Myrian. (2006). Death from external causes - Recent evolution and the need for change of focus. OSH \& Development, Swedish, No 8, December. 
de "economia invisível". As novas mutações que ocorrem no processo e organização do trabalho contribuem para a existência de uma relação perversa, em que o trabalhador tem seu direito ao trabalho desrespeitado. Considerando-se a discussão sobre a negação/centralidade do trabalho em relação ao mercado formal/informal, faz-se necessário analisar as relações sociais de trabalho dos vendedores ambulantes.

Entre os comerciantes de rua que estão à margem da proteção legal, os camelôs e os vendedores ambulantes (os que não possuem instalações ou equipamentos) pertencem ao grupo considerado mais fragilizado, que sofre mais diretamente perseguições e/ou violência nas atividades de trabalho. Nesta perspectiva, NUNES \& THEODORO $^{46}$ assinalam que os camelôs pertencem ao grupo considerado mais fragilizado, que sofre mais diretamente perseguições e/ou violência na atividade de trabalho, como as ações repressivas por parte de organismos governamentais.

Os autores destacam a fragilidade do comércio de rua como atividade econômica, em função das disputas pelo mercado. Os trabalhadores estão sujeitos a perseguições e violência. As diversas alianças entre camelôs e os comerciantes e entre os próprios pares garantem a existência do comércio de rua e ao mesmo tempo o subordina à lógica da concorrência entre os diferentes capitais comerciais.

Fica a indagação sobre a importância do trabalhador informal de rua, como os vendedores ambulantes e catadores de materiais recicláveis, que faz parte do exército industrial de reserva ${ }^{47}$ para o sistema capitalista. A existência de uma identidade

46 NUNES, Christiane Girard Ferreira \& Mário Theodoro (2006). Work and Health in the informal sector: Domestic work and street commerce. OSH \& Development, Swedish, № 8, December.

47 Exército Industrial de Reserva: expressão empregada por Karl Marx para designar o conjunto dos trabalhadores desempregados. A esse mesmo contingente humano ele deu também a denominação de população relativa excedente. Marx analisou a existência do exército industrial de reserva como um fenômeno inerente à própria produção capitalista. Para ele, os capitalistas, a fim de vencerem os concorrentes, são obrigados a empregar continuamente novas máquinas, com intuito de baratear os custos de produção e aumentar a produtividade do trabalho. O emprego de novas máquinas e novos equipamentos leva à diminuição da parte relativa à mão-de-obra, o que provoca o chamado desemprego tecnológico. Marx analisa também outras formas de criação do exército industrial de reserva: mãode-obra de jovens que não são absorvidos em sua totalidade pelo mercado de trabalho; trabalhadores agrícolas que têm empregos temporários ou que se deslocam em decorrência da mecanização da agricultura; pequenos proprietários e artesões arruinados. Marx salientou o fato de que o capitalismo, mesmo em época de prosperidade, necessita da existência de número razoável de trabalhadores desempregados com finalidade de impedir uma maior pressão sobre o preço dos 
negativa para esse tipo de trabalho faz com que o trabalhador informal seja tratado como um bandido e obrigado a fugir para não ter as mercadorias apreendidas nas situações de fiscalização. Por outro lado, é digno de nota que sua existência e atuação cumpra uma função social e atenda a diversos interesses, além de ser um fator inerente à conformação do Capitalismo. Constata-se que a falta de estatuto profissional regulamentado e a ausência de direitos no trabalho contribuem para mais violência que incide sobre esses indivíduos.

O interesse pelos vendedores ambulantes; catadores de materiais recicláveis; pescadores de lagosta e pescadores de atum; e colhedores de laranja surge a partir de projetos de pesquisa sobre as condições de saúde e segurança no trabalho informal, desenvolvidos pela Fundacentro/Ministério do Trabalho e Emprego. A experiência de trabalho de campo sobre as condições de saúde, trabalho e vida de pescadores de lagosta e pescadores de atum na região Nordeste do Brasil nos mostra uma dura realidade.

Encontramos nesta atividade sujeitos que trabalham em sistema de parceria na pesca da lagosta, por exemplo. A divisão da produção ocorre de maneira desigual entre os pescadores, o mestre de barco e os "armadores", isto é, os donos de barcos. Os pescadores ficam com a menor parte dos lucros. Apesar desse tipo de pesca ser considerado artesanal, percebemos que na verdade, existe uma relação de assalariamento. Chama a atenção o vínculo de trabalho precário, a falta de proteção e de direitos, as péssimas condições de trabalho, a intensificação do trabalho, o baixo rendimento e as formas de exploração a que os pescadores estão submetidos.

Os pescadores de atum são desempregados da pesca comercial que, para sobreviver, estão ocupados na "pesca artesanal" do camarão e da lagosta, na agricultura, na pecuária, ou na construção civil. São assalariados sem carteira assinada que 
sobrevivem de "bicos" e trabalhos temporários. Pretendem retornar para a pesca comercial por causa da estabilidade, das garantias, dos direitos e das melhores condições de trabalho, mas encontram barreiras nos critérios de qualificação e escolaridade e na falta de emprego, devido à proibição de barcos estrangeiros irregulares permanecerem na costa brasileira.

Já os colhedores de laranja são trabalhadores agrícolas e rurais que trabalham por temporada, durante a colheita de diversas plantações. Não possuem registro em carteira e ganham por produção. Vivem em condições de trabalho precárias, com baixos rendimento, enfrentando pressões na relação com os "gatos" ou empreiteiros e experiências negativas em relação a cooperativas fraudulentas. A terceirização da mãode-obra prevalece no trabalho no campo. As indústrias de álcool e açúcar e de sucos de laranja não possuem qualquer responsabilidade sobre o trabalhador. Quando os colhedores sofrem acidentes ou ficam doentes, com a falta de proteção, precisam recorrer a uma assistência a saúde pública precária e à ajuda financeira de amigos, parentes e da vizinhança para poder sobreviver junto à família.

Segundo dados do Censo Agropecuário $2006^{48}$ e do DIEESE ${ }^{49}$, apenas $13 \%$ da População Economicamente Ativa (PEA) na agropecuária é formal. Entre os trabalhadores formais na área rural, 29\% estão na lavoura temporária e 6,5\% na pesca. Vale destacar que $68 \%$ da PEA é formada por trabalhadores por conta-própria, trabalhadores não-remunerados e trabalhadores na produção para o próprio consumo. São trabalhadores que estão ocupados na agricultura familiar e nos pequenos empreendimentos. A maioria não paga as mensalidades do Seguro Social e, sendo assim, não tem perspectiva de aposentadoria e benefícios em caso de acidentes de trabalho e doenças profissionais. Estes dados demonstram a importância de se estudar

48 Censo Agropecuário 2006. http: www.ibge.gov.br . Consulta no dia 01/10/2009.

49 Departamento Intersindical de Estatística e Estudos Socioeconômicos (DIEESE) e Ministério do Desenvolvimento Agrário (MDA) (2008). Estatísticas do meio rural. Brasília: MDA: DIEESE, 280p., http://www.dieese.org.br . Consulta no dia: 28/09/2009. 
os pescadores e colhedores de laranja, pois entre eles, existe um número expressivo de trabalhadores que se encontram sem qualquer direito de cidadania.

\section{A construção deste estudo}

O primeiro capítulo discute o conceito de informalidade ${ }^{50}{ }^{51}$, considerando-se os discursos que apontam sua origem e contexto socioeconômico, quer produzidos ou não por órgãos oficiais ${ }^{52}$. Nesta perspectiva, são analisadas as diferentes abordagens teóricas $^{53}$ sobre o trabalho informal, como a abordagem neoliberal e a estruturalista ${ }^{54} 55$ 5657 , a abordagem da economia popular; a abordagem do setor marginal ${ }^{58}$ 59; e a abordagem do desenvolvimento e do subdesenvolvimento capitalista ${ }^{6061}$. Os diversos enfoques se baseiam na literatura nacional e internacional sobre o tema do trabalho informal, levando-se em conta os principais autores que discutem a questão.

O segundo capítulo discute, em primeiro lugar, a questão social, isto é, o desemprego; o trabalho precário; a pobreza e a vulnerabilidade social; e o papel do Estado. Partirei dos seguintes autores: Robert Castel; Pierre Rosanvallon; e Amartya Sen. Em segundo lugar, aborda-se a questão das desigualdades socioeconômicas, dos

\footnotetext{
50 CACCIAMALI, Maria Cristina (2000). As economias informal e submersa: conceitos e distribuição de renda. IN: José Márcio Camargo, Fabio Giambiagi (orgs). Distribuição de renda no Brasil. Rio de Janeiro: Paz e Terra, $2^{\circ}$ edição.

51 OIT (1972). Employment, Income and Equality: A Strategy for Increasing Productive Employment in Kenya. Genebra.

52 CUT (2000). Mapa do Trabalho Informal do Município de São Paulo. São Paulo.

53 THEODORO, Mario (2002). O Estado e os Diferentes Enfoques sobre o Informal. Brasília, IPEA, novembro de 2002, Texto para Discussão $n^{\circ} 919$.

54 ROSENBLUTH, Guillermo (1994). Informalidad y Pobreza em América Latina. Revista de la CEPAL, Nº 52, abril.

55 KOWARICK, Lúcio (1975). Capitalismo e Marginalidade na América Latina. Rio de Janeiro, Ed. Paz e Terra, pp. 61-62.

56 CORAGGIO, José Luis. Del Sector Informal e La Economia Popular. Nueva Sociedad, pp. 118-131

57 ROSENBLUTH, Guillermo (1994). Informalidad y Pobreza em América Latina. Revista de la CEPAL, Nº 52, abril.

58 NUN, José (1999). El Futuro del Empleo y la Tesis de la Masa Marginal. Desarrollo Econômico, vol. 38, nº 152, jan-mar.

59 QUIJANO, Aníbal (1998). La Economia Popular y sus Caminos en América Latina. Lima, Mosca Azul.

60 SINGER, Paul (1973). "Urbanização, Dependência e Marginalidade na América Latina”. IN: SINGER, Paul. Economia Política da Urbanização. São Paulo,

Brasiliense, pp. 63-90.

61 SINGER, Paul (1996). Desemprego e Exclusão Social. São Paulo em Perspectiva, vol. 10, nº 1, jan-mar, pp. 3-13
} 
padrões de desenvolvimento capitalista em relação às oportunidades sociais existentes no leste asiático e na América Latina. Em terceiro lugar, faz-se uma análise dos direitos sociais e de cidadania dos trabalhadores no contexto da realidade brasileira. A construção da cidadania no Brasil ocorreu de maneira singular e distinta dos países europeus. Diante da política neoliberal, a questão que se apresenta hoje está ligada, principalmente, à legitimidade e eficácia dos direitos. Com as grandes transformações econômicas, é necessário repensar políticas e conceitos que possam abranger as relações entre trabalho, direito e cidadania.

O terceiro capítulo consiste numa discussão sobre a metodologia de pesquisa utilizada, além de um relato sobre o trabalho de campo na cidade, no campo e no mar. Analisa-se o estudo exploratório, que possibilita a compreensão do desenho de pesquisa elaborado. O método de pesquisa qualitativo é utilizado para compreender as trajetórias sociais e profissionais dos trabalhadores informais. O capítulo ainda contempla uma revisão da literatura sobre o tema da informalidade, com o objetivo de tornar possível a comparação das informações estatísticas, da produção teórica existente e dos dados levantados durante a pesquisa de campo, a partir da experiência de observação.

Concordamos com os autores que defendem a compreensão das trajetórias profissionais $^{62}$ como aspectos privilegiados para verificar as racionalidades que orientam as ações dos trabalhadores: suas estratégias de sobrevivência e resistências, a formação, manutenção e organização de grupos de desempregados e informais. Também valorizamos a importância de analisar os efeitos das formas de exploração sobre as condições de saúde e de trabalho. 
Segundo DUBAR ${ }^{63}$, a análise das trajetórias sociais relaciona-se com o tema da articulação de dois aspectos do processo biográfico. A trajetória objetiva é definida como "seqüência das posições sociais ocupadas durante a vida, medida por categorias estatísticas e condensada numa tendência geral". Em contraste, a "trajetória subjetiva é expressa em diversos relatos biográficos, por meio de categorias inerentes, remetendo a mundos sociais e condensáveis em formas identitárias heterogêneas". Para o autor, "confrontar ambas as análises toma toda sua importância ao se tentar apreender identidades sociais como processos ao mesmo tempo biográficos e institucionais".

O quarto capítulo apresenta os resultados encontrados na pesquisa de campo. A análise dos dados é realizada a partir de um referencial teórico referente aos temas em discussão. A análise se detém nas trajetórias ocupacionais e de vida de trabalhadores que, após o desemprego, por não conseguirem empregos com o mesmo status ou com melhores salários, recorreram ao trabalho informal como estratégia de sobrevivência. A questão da identidade profissional chamou a atenção, na medida em que esses desempregados perderam suas identidades profissionais como trabalhadores fabris, bancários, técnicos e pequenos empresários, passando a ser pouco valorizados na sociedade por conta de sua situação de subemprego. As formas de organização dos trabalhadores por meio dos movimentos sociais e sindicais também foram analisadas.

Nesse capítulo, discutem-se algumas questões que nos parecem relevantes na discussão das trajetórias sociais e ocupacionais. Apesar de não representarem a maior parte dos desempregados, as mulheres, jovens e idosos têm presença significativa no mercado informal. Além disso, podemos considerar que esses trabalhadores se encontram em condições mais vulneráveis na informalidade. Abordam-se as condições de vida e renda dos vendedores ambulantes, catadores de materiais recicláveis,

63 DUBAR, Claude. Trajetórias sociais e formas identitárias: alguns esclarecimentos conceituais e metodológicos. Educação e Sociedade, vol. 19, $\mathrm{n}^{\circ} 62$, Campinas Abr., 1998. 
pescadores de lagosta e colhedores de laranja. Percebe-se que as condições de vida estão diretamente relacionadas ao salário e aos rendimentos recebidos pelos trabalhadores.

No quinto capítulo, entram em questão as consequências das condições e da organização do trabalho sobre a saúde física e mental dos trabalhadores - no caso, os vendedores ambulantes; catadores de materiais recicláveis; pescadores; e colhedores de laranja. As condições de segurança no trabalho mereceram atenção especial. Os riscos de violência, como roubos, tentativas de homicídio, acidentes de trânsito, atropelamentos e agressões físicas e verbais, entre outros, estão presentes no cotidiano desses trabalhadores. O sofrimento mental que vivenciam é excessivo e constante, numa rotina de intensificação no trabalho, jornadas prolongadas, ritmo incessante, ganhos por produção, rendimentos baixos, falta de perspectivas e de proteção legal. O prazer no trabalho e a expectativa positiva em relação ao futuro são os meios encontrados para suportar as dificuldades encontradas e para se manter nas ocupações precárias.

O estudo espera poder contribuir para melhorias nos programas de atenção aos trabalhadores informais e para políticas públicas voltadas ao emprego e à geração de renda, que tenham como objetivos o trabalho decente, a saúde e a segurança dos trabalhadores. 


\section{CAPÍtULO 1: ABORDAGENS TEÓRICAS SOBRE O TRABALHO INFORMAL}

\subsection{Debate sobre o conceito de informalidade}

Segundo CACCIAMALI ${ }^{64}$, o conceito de setor informal tem sido empregado para caracterizar dois fenômenos teoricamente distintos. O primeiro, identificado nos anos 70, define este setor como representando o conjunto das atividades econômicas em que não há separação nítida entre capital e trabalho. Neste grupo estariam classificados os trabalhadores por conta própria, os prestadores de serviços independentes, os vendedores autônomos, os pequenos produtores e comerciantes e os ajudantes familiares ou contratados.

Para a autora, a segunda interpretação foi lançada no final dos anos 90 nos países industrializados e indica as atividades econômicas que fogem da regulação do Estado, seja esta tributária, trabalhista ou de outro tipo. Esta forma de conduzir uma atividade econômica firmou-se, na literatura especializada com a denominação de economia subterrânea, submersa ou invisível. CACCIAMALI destaca que essas atividades, por estarem parciais ou totalmente fora da legislação vigente, têm de sonegar informações sobre o número de empregos gerados, o nível de produção, o volume comercializado e as receitas percebidas, o que leva à subestimação desses agregados nas estatísticas oficiais. Acredita-se que neste caso a autora esteja se referindo ao que possamos denominar de uma "nova informalidade", que tem aumentado a cada dia junto às formas de informalidade consideradas tradicionais.

64 CACCIAMALI, Maria Cristina (2000). As economias informal e submersa: conceitos e distribuição de renda. In: CAMARGO, José Márcio \& Giambiagi, Fabio (orgs.). Distribuição de renda no Brasil. Rio de Janeiro: Paz e Terra, IERJ. 
O termo "setor informal" foi cunhado no fim dos anos 60 pela Organização Internacional do Trabalho (OIT) e utilizado pela primeira vez nos relatórios sobre Gana e o Quênia, elaborados no âmbito do Programa Mundial de Emprego, em $1972^{6566}$. O programa teve como objetivo avaliar a evolução do emprego e da renda nos países em desenvolvimento, principalmente naqueles em que o estado tinha implementado um processo rápido de industrialização.

Esse processo resultara em inúmeras e variadas atividades que, embora modernas, possuíam características peculiares: não eram organizadas com base no trabalho assalariado e seus níveis de remuneração se distanciavam fortemente da média estipulada para seu setor, situando-se próximos daqueles das atividades tradicionais. No relatório da OIT são destacados enfoques duais da estrutura econômica e critérios para reconhecer os setores formal e informal, em suas denominações como setores tradicional e moderno.

Para superar as dificuldades teóricas encontradas durante a primeira fase de aplicação do conceito de setor informal, os estudiosos do tema passaram a abordá-la a partir das relações do trabalhador com os meios e instrumentos de produção. Nesta perspectiva, o setor informal é denominado por pequena produção e definido como o conjunto das atividades econômicas em que o produtor direto, de posse dos instrumentos de trabalho e, com o auxílio da mão-de-obra familiar e alguns ajudantes, produz bens ou serviços.

Segundo o estudo elaborado pelo Programa Regional de Emprego para a América Latina e Caribe (PREALC), da OIT, o setor informal é "composto por pequenas atividades urbanas, geradoras de renda, que se desenvolvem fora do âmbito

65 Uma das principais conclusões alcançadas nos relatórios foi que o problema social mais importante naqueles países não era o desemprego, mas sim a existência de um grande número de "trabalhadores pobres", ocupados em produzir bens e serviços sem que suas atividades fossem reconhecidas, registradas, protegidas ou regulamentadas pelas autoridades públicas. 
normativo oficial, em mercados desregulamentados, competitivos e com baixo nível de organização, em que é difícil distinguir a diferença entre capital e trabalho. Estas atividades se utilizam pouco capital, técnicas rudimentares e mãos-de-obra pouco qualificadas, que proporcionam emprego instável de reduzida produtividade e baixa renda".

De acordo com a caracterização da OIT, as atividades informais teriam os seguintes elementos ${ }^{67}$ :

1. Baixos requerimentos em termos de capital, capacitação e organização;

2. Empresas familiares ou individuais;

3. O aporte de recursos é de origem doméstica;

4. Operações em pequena escala;

5. Sistema produtivo e trabalho-intensivo, apoiado em tecnologia antiquada e adaptada;

6. Mercados competitivos e desregulados;

7. Há facilidade de entrada;

8. A mão-de-obra qualifica-se externamente ao sistema escolar formal.

Segundo a mesma organização, o setor formal apresenta as seguintes características:

1. Defronta-se com barreiras à entrada;

2. Depende de recursos externos;

3. A propriedade do empreendimento é impessoal;

67 CACCIAMALI, Maria Cristina (2000) idem. 
4. Opera em larga escala;

5. Utiliza processos produtivos intensivos em capital e a tecnologia é importada;

6. A mão-de-obra adquire as qualificações requeridas por meios de escolaridade formal;

7. Atua em mercados protegidos através de tarifas, cotas, etc.

Para medir o trabalho informal, a OIT toma a unidade produtiva como ponto de partida. Para a organização, todos os trabalhadores ocupados em micro e pequenas empresas com menos de cinco empregados são informais. Percebe-se que entram na contagem também os empregadores e seus familiares que trabalham na produção nestas empresas. A forma de quantificação deste setor informal ultrapassa a definição de informalidade relacionada a um excedente de mão-de-obra em ocupações no setor nãoorganizado do mercado de trabalho (desemprego invisível), ou mesmo a definição que liga trabalho informal com força de trabalho empregada de maneira atípica nas formas de subcontratação e terceirização.

Em relação à definição da OIT, é possível questionar o fato de que, atualmente, algumas empresas com menos de cinco funcionários empregados fazem parte do setor dinâmico da economia, empregando inclusive tecnologia avançada. Nesta perspectiva, devemos lembrar das pequenas empresas em que parte significativa da produção ou da administração é gerenciada por empresas prestadoras de serviços, onde se encontra a grande maioria dos trabalhadores em situações informais e precários.

Este fato deve ser destacado por evidenciar a existência de diversas formas de relações de produção atípicas, mesmo nas pequenas empresas. Percebe-se que a situação se agrava porque a fiscalização pelo Estado costuma ser menor nas pequenas empresas ou pequenos negócios - até mesmo por ser difícil o real mapeamento destes 
empreendimentos. Esse fato contribui para a ocorrência de inúmeras irregularidades fiscais, tributárias, trabalhistas e principalmente de práticas criminais, por exemplo, as conhecidas "empresas de fachada" para "lavagem de dinheiro", sonegação impostos e até mesmo para o tráfico e o contrabando de mercadorias e drogas.

Para CACCIAMALI ${ }^{68}$, a aplicação do termo "setor informal" à partir das formas de inserção do trabalhador na produção busca romper a abordagem dual estática, substituindo-a por um enfoque dinâmico, subordinado e intersticial. Desta maneira, "o espaço informal transforma-se, ao longo do tempo, subordinado aos movimentos da produção tipicamente capitalista e aos decorrentes perfis de demanda e de distribuição de renda. $\mathrm{O}$ espaço econômico informal, que é intersticial às atividades econômicas dominantes, é ocupado de forma permanente e constitui parte integrante do mercado de trabalho, embora o tipo de produtores e ofertas de bens e de serviços modifique-se ao longo do tempo. O fluxo de renda também é permanente entre os setores formal e informal, através de vínculos de sub-contratação, prestações de serviços, venda de mercadorias, etc. Destaca-se que a coexistência entre as atividades formais e informais ocorre em todas as economias avançadas".

Esta nova abordagem do setor informal, de acordo com a autora, "permite perceber que a produção e as relações de produção se estruturam em um continuum, em vez de apenas dois setores". Sendo assim "é possível identificar diversos tipos de inserções ocupacionais, além do trabalho assalariado inseridos nas firmas tipicamente capitalistas" como, por exemplo:

1. Assalariamento sem contrato legal de trabalho;

2. Assalariamento ocasional ou temporário;

3. Assalariamento sazonal;

68 CACCIAMALI (2000) idem. 
4. Assalariamento disfarçado ("trabalhadores autônomos" que se encontram subordinados a uma determinada e única firma);

5. Trabalho por conta própria, autônomo ou independente;

6. Pequenos estabelecimentos;

7. Quase-empresas capitalistas;

8. Emprego doméstico.

Para CACCIAMALI ${ }^{69}$ "o perfil ocupacional passa a ser distinguido por forte heterogeneidade, no que se refere ao espaço econômico do setor informal, deve ser destacado quanto às ocupações, padrões diferenciados de condições de trabalho e aos níveis de renda".

A metodologia empregada pela $\operatorname{OIT}^{70}$ e PREALC é considerada referência para os estudos sobre a economia informal. A partir dela, se constroem esquemas de interpretações sobre o tema, sendo utilizada também pelos pesquisadores do trabalho informal no município de São Paulo ${ }^{71}$. Tal metodologia enquadra os trabalhadores informais nas seguintes categorias:

1. Assalariados com carteira assinada em empresas com até cinco empregados;

2. Assalariados sem carteira assinada em empresas com até cinco empregados;

3. Assalariados sem carteira assinada em empresas com mais de cinco empregados;

4. Empregadores de empresas com até cinco empregados;

5. Donos de negócio familiar;

6. Autônomos que trabalham para o público;

69 CACCIAMALI (2000) idem.

70 Recomendação aprovada na $15^{\mathrm{a}}$ Conferência de Estatísticos do Trabalho, em 1993.

71 CUT (2000). Mapa do Trabalho Informal do Município de São Paulo. São Paulo. 
7. Autônomos que trabalham para empresas;

8. Empregados domésticos;

9. Trabalhadores familiares.

Como se pode notar, a classificação abrange o emprego informal propriamente dito (assalariados sem carteira assinada em empresas com até cinco empregados; autônomos; empregados domésticos e trabalhadores familiares), bem como o emprego formal no setor informal (assalariados com carteira assinada em empresas com até cinco empregados); mas também o emprego informal fora do setor informal (trabalhadores sem carteira assinada em empresas com mais de cinco empregados); e por fim, os micro-empresários: empregadores de menos de cinco empregados e donos de negócio familiar que, dependendo do seu faturamento, podem ser considerados pelo governo como pequenos empresários.

Em nossa sociedade, a possibilidade dos trabalhadores participarem do processo de produção social está condicionada pela expansão das atividades econômicas, ou seja, a força de trabalho está submetida ao processo de acumulação de capital. Neste sentido, a forma de inserção da mão-de-obra no mercado de trabalho está determinada pelas possibilidades abertas pela evolução do desenvolvimento econômico capitalista.

Nesses termos, POCHMANN ${ }^{72}$ destaca duas formas de inserção no processo produtivo:

1. Trabalhadores diretamente envolvidos no processo de acumulação de capital;

2. Trabalhadores excedentes das necessidades diretas do processo de acumulação do capital. Nestes pode ser identificada uma subdivisão:

72 POCHMANN, Márcio (2000). "O Excedente de mão-de-obra no Município de São Paulo”. In: CUT, Mapa do Trabalho Informal do Município de São Paulo. São Paulo, CUT, pp. 11-18 
3. Trabalhadores submetidos ao desemprego aberto (visível), que fazem diretamente parte da concorrência por postos no mercado de trabalho;

4. Trabalhadores com ocupações envolvidas com a própria subsistência (desemprego invisível), que, em geral, "refletem formas não-capitalistas ou pré-capitalistas de produção". Estes constituem o segmento não-organizado do mercado de trabalho.

Mais recentemente, com a rápida e profunda transformação no Capitalismo, por meio de uma nova onda de inovação no paradigma tecnológico e de modificações na produção e organização do trabalho, sobretudo nas grandes empresas, têm surgido condições novas de produção e reprodução de mão-de-obra excedente. Percebem-se novas oportunidades ocupacionais no segmento não-organizado do mercado de trabalho.

Percebe-se que a economia informal é suficientemente heterogênea para possibilitar interpretações diversas. Estas dependem do que se considera como economia informal. Algumas interpretações relacionam o mercado formal com emprego e o mercado não-formal com desemprego e sub-emprego, isto é, a análise ocorre a partir do marco legal. Outras abordagens discutem o tema a partir das diferentes formas de organização da produção. Por outro lado, algumas análises consideram o subemprego como um resíduo marginal da economia, enquanto outras tentam mostrar as relações existentes entre o desenvolvimento do Capitalismo e os fenômenos do desemprego e do sub-emprego.

Outro debate é sobre a funcionalidade da economia informal em relação ao Capitalismo: uns a compreendem como um setor marginal, correspondente a formas de produção não-capitalista; outros a consideram como uma inserção perversa dos trabalhadores na economia capitalista. Diversas interpretações existem também sobre 
as relações que se estabelecem entre o trabalho informal e os fenômenos da pobreza e da desigualdade na distribuição de renda. Segundo POCHMANN ${ }^{73}$, o excedente de mão-de-obra no mundo está em torno de 150 milhões de trabalhadores desempregados (desemprego aberto) e 850 milhões de subempregados.

De acordo com a CUT, há duas formas básicas de se definir o trabalho informal: 1) pelo critério da legalidade da atividade econômica, ou 2) pela classificação da natureza capitalista ou não do empreendimento. De acordo com Pochmann, as posições se definem das seguintes maneiras:

1. "De um lado, há aqueles que definem o trabalho informal como aquele cujas atividades produtivas são executadas à margem da lei, especialmente da legislação trabalhista vigente em um determinado país. Aqui estariam os trabalhadores por conta própria - grande parte dos quais não contribui para a previdência os trabalhadores sem carteira assinada e os não-remunerados. Este ponto de vista compreende o trabalho informal a partir da precariedade da ocupação".

2. "De outro lado, pode-se definir o trabalho informal como aquele vinculado a estabelecimentos de natureza não tipicamente capitalista. Estes estabelecimentos se distinguiram pelos baixos níveis de produtividade e pela pouca diferenciação entre capital e trabalho. O núcleo básico seria formado pelos trabalhadores por conta própria, mas também pelos empregadores e empregados de pequenas firmas com baixos níveis de produtividade",74.

73 POCHMANN, Márcio (2001). O Emprego na Globalização. São Paulo: Boitempo Ed. 74 CUT (2000). Mapa do Trabalho Informal do Município de São Paulo. São Paulo. 
A CUT faz a opção de considerar a segunda opção. De acordo com este segundo enfoque, o trabalho informal não é definido pelo respeito ou não ao marco legal, mas de acordo com a dinâmica econômica das unidades produtivas. Este setor é caracterizado como desorganizado, não-estruturado e com baixa produtividade. Ainda segundo a CUT, este enfoque pretende identificar os trabalhadores vinculados ao sistema simples de produção de mercadorias, desta maneira:

"Os trabalhadores informais seriam aqueles vinculados ao chamado sistema simples de produção de mercadorias e serviços, onde o assalariamento não é a regra, sendo antes a exceção. Aqui, o empregador também trabalha como empregado, podendo fazer uso de ajudantes não-remunerados (geralmente familiares), no caso dos autônomos, como também contratar empregados com ou sem carteira assinada, no caso das microempresas, geralmente com até 5 empregados" 75 .

A capacidade de geração de renda do trabalho informal, assim definido, é determinada pela expansão do setor capitalista da economia, o qual gera demanda por bens e serviços. Neste sentido, o trabalho informal pode estar vinculado tanto às cadeias produtivas das empresas capitalistas, como ao poder de consumo dos trabalhadores formais. Deve-se ressaltar o caráter subordinado do setor informal no sistema econômico capitalista. Para a $\mathrm{CUT}^{76}$, explicitar e quantificar os trabalhadores realmente vinculados ao segmento informal, definido como não tipicamente capitalista, possibilita diferenciá-los daqueles trabalhadores com ocupações precárias em atividades capitalistas. Este segundo grupo inclui parte significativa dos trabalhadores sem carteira assinada, os quais não seriam informais, mas trabalhadores do setor capitalista cujos empregadores desrespeitam a legislação trabalhista vigente.

75 Idem ibidem.

76 Idem ibidem. 
A heterogeneidade do setor informal é grande, mesmo desconsiderando os trabalhadores sem carteira de médias e grandes empresas. Segundo a definição sugerida pela OIT e pelo IBGE, os trabalhadores informais seriam classificados da seguinte forma:

1. Autônomo subordinado às empresas, tanto na produção (costureiras), como na distribuição (vendedores por comissão);

2. Autônomos produtores de bens e vendedores de serviços ao público, onde se encontram os ambulantes, encanadores, pedreiros, pintores etc.

3. Pequenas empresas familiares, como padarias, confecções, comércios, mercearias e oficinas de reparação, que muitas vezes sobrevivem da clientela local, mas tendo sua inserção definida pela lógica das grandes empresas;

4. As "quase-empresas capitalistas", que fazem uso de mão-de-obra assalariada, mas possuem algumas peculiaridades que justificam sua inclusão na categoria dos informais, por exemplo: o assalariamento convive com jornadas de trabalho não reguladas pela lei, sendo os salários abaixo do verificado nas grandes empresas. Também não se presencia uma separação clara entre o rendimento do empregador e a taxa de lucro do seu empreendimento.

5. Por último, a economia solidária: cooperativas de trabalho para a produção de mercadorias e prestação de serviços. 
ROSENBLUTH ${ }^{77}$, da CEPAL, considera como integrantes do setor informal os trabalhadores por conta própria; os trabalhadores familiares sem remuneração e os trabalhadores das empresas com até cinco assalariados e os empregados domésticos. Define o setor informal como um segmento em que o trabalho é instável, precário, de baixa produtividade, de menor rendimento e com tecnologia rudimentar.

O autor defende a tese de que o nível de desenvolvimento econômico condiciona a situação do emprego e do desemprego e, portanto, incide nas condições de vida dos trabalhadores no setor informal. Desta maneira, quanto maior o desenvolvimento de um país, menor será a proporção de informais na força de trabalho.

\subsection{Diferentes enfoques teóricos sobre trabalho informal}

A análise da economia demonstra a sua inserção no campo social. Os processos econômicos são resultados de práticas e estruturas sociais dinâmicas. O pensamento econômico é um produto historicamente datado com seus conceitos construídos socialmente e ao longo do tempo.

Nesta perspectiva a idéia de trabalho como atividade em busca de remuneração, em oposição à divisão tradicional de atividades; a possibilidade de transação impessoal entre desconhecidos numa situação de mercado, ao contrário das trocas econômicas baseadas na confiança e na "boa fé", como na economia doméstica; a noção de investimento em longo prazo, a concepção de empréstimo com juros, a idéia de contrato, enfim o que a ciência econômica considera como dados são, na verdade,

77 ROSENBLUTH, Guillermo (1994). Informalidad y Pobreza en América Latina. Revista de la CEPAL, № 52, abril. 
sistemas e representações de práticas sociais inseridas numa ordem social e cultural e produtos de uma história coletiva ${ }^{78}$.

Esta visão critica a teoria econômica centrada na concepção de homo economicus, paradigma do comportamento econômico racional. O espírito e o objeto das práticas econômicas não são mais do que a economia das condições de produção e reprodução dos agentes e instituições econômicas. Nesse sentido, a Economia e a Sociologia se unem para analisar as condições sociais e econômicas.

Faz-se necessário superar a dicotomia entre Sociologia e Economia na análise das transformações no mundo do trabalho. ABRAMO ${ }^{79}$ destacou a importância da integração dessas perspectivas nos estudos sobre os processos de reestruturação e seus efeitos sobre o emprego e o trabalho; as novas formas de relações sociais de produção; as mudanças tecnológicas, organizacionais e na natureza do trabalho, que vêm ocorrendo no interior dos vários tipos de empresas articuladas ao longo das cadeias produtivas; as condições de trabalho e a qualificação de trabalhadores e trabalhadoras; as novas segmentações da força de trabalho, como as dimensões de gênero, raça, etnia, nacionalidade; as possibilidades de enriquecimento e precarização do trabalho; os novos espaços e formas de interlocução e negociação entre os atores produtivos; e as trajetórias ocupacionais, entre outros.

A discussão sobre informalidade diz respeito aos problemas sociais que possuem caráter heterogêneo e mutante. Nesta perspectiva, as teorias sobre a economia ou o trabalho informal são tentativas de organizar mentalmente, mas também praticamente, os fenômenos sociais, posicionando-os para atender à ordem social. Para FASSIN ${ }^{80}$ “a teoria sobre informalidade são topologias sociais que favorecem um sistema de

78 BOURDIEU, Pierre. (2000) Las estructuras sociales de la economía. Barcelona, Ed. Anagrama, 2003, pp. 17-18. 79 ABRAMO, Laís. Desafios atuais da Sociologia do trabalho na América Latina: algumas hipóteses para a discussão. Buenos Aires, CLACSO (http://bibliotecavirtual.clacso.org.ar/ar/libros/cyg/ytabajo/abramo.rtf). 
classificação que é ao mesmo tempo um dispositivo de desclassificação, isto é, servem para encobrir a realidade tanto quanto para iluminá-la. A ambivalência ideológica desta noção não impede que se orientem ações e se legitimem políticas em relação ao setor informal".

O presente texto buscará um diálogo interdisciplinar, pois acreditamos que isso possibilite uma melhor compreensão da complexidade do tema, que supera as subdivisões, estabelecidas por especialidades em compartimentos estanques. A importância dessa perspectiva para o entendimento do trabalho informal ou do "setor informal" é evidente e será priorizada neste estudo.

A noção de informalidade é definida como a ausência de articulação ou inserção formal no processo de produção, como o trabalho informal e como a insegurança crônica do emprego não-registrado. O debate sobre informalidade tem as mesmas características que as discussões dos conceitos de marginalidade na América Latina; underclass nos EUA e de exclusão social na França.

Segundo FASSIN, a noção de marginalidade utiliza as categorias marxistas para descrever os aspectos socioeconômicos dos países latino-americanos e a marginalização das próprias sociedades em termos de desenvolvimento social e econômico. A categoria social de underclass refere-se a um grupo econômico mais desfavorecido, socialmente menos móvel e vítima da pobreza, da delinqüência, do racismo e do estigma social. A terceira noção se refere aos que estão à margem da normalidade, inadaptados, marginais ou a-sociais, identificando-os com uma problemática de patologia social ou vulnerabilidade social.

O tema da informalidade é abordado de maneira interdisciplinar por NORONHA $^{81}$, que ressalta os diferentes significados de formalidade e informalidade,

81 NORONHA, Eduardo G. "Informal”, ilegal, injusto: percepções do mercado de trabalho no Brasil. Revista Brasileira de Ciências Sociais, v. 18, n. 53, São Paulo, outubro de 2003. 
bem como as noções de contratos legítimos. O autor busca redefinir o conceito de "informalidade" com base nos diferentes princípios que guiam as interpretações de economistas (formal/informal), juristas (legal/ilegal) e do senso comum (justo/injusto). No estudo, faz-se uma crítica ao uso do conceito, dada a diversidade de situações contratuais abarcada por ele. O pesquisador argumenta sobre a necessidade de se analisar as noções populares de contrato de trabalho "justo", por serem acepções que se relacionam com noções econômicas e jurídicas de contratos legítimos.

NORONHA também aponta para as dificuldades analíticas do tema, devido à diversidade de processos que geram os contratos atípicos, que representam as relações de "informalidade" no Brasil. A partir deste quadro, ressalta a necessidade de estudos interdisciplinares no sentido de uma melhor compreensão do tema. É válido pontuar que farei uma discussão interdisciplinar mais adiante. Acredito que ela poderá ser extremamente produtiva, na medida em que possibilite uma melhor compreensão da complexidade do assunto, que supera as subdivisões estabelecidas por especialidades.

Percebe-se que o tema da economia informal é polêmico e controverso e que não existe consenso quanto à organização do debate. Enfim, trata-se de uma questão que requer atenção, pois a informalidade e a formalidade estão presentes lado a lado na economia e podemos notar um processo de informalização cada vez maior. As formas arcaicas e tradicionais de trabalho informal coexistem com novas informalidades. A heterogeneidade existente nas atividades informais e na composição dos trabalhadores dificulta a conceituação e as abordagens teóricas.

As diversas interpretações do trabalho informal se sustentam em concepções teóricas diferentes. Na discussão sobre o trabalho e a economia informal entre diversos autores $^{82} 83{ }^{84}$, prevalecem as seguintes abordagens sobre o tema: a) Neoliberal;

82 ROSENBLUTH, Guillermo (1994). Informalidad y Pobreza en América Latina. Revista de la CEPAL, No 52, abril. 83 CORAGGIO, José Luis. Del Sector Informal e la Economia Popular. Nueva Sociedad, pp. 118 - 131 
b) Estruturalista; c) Marginalista; e d) relacionada à Teoria da Dependência. Passaremos à apresentação de cada uma delas.

\subsubsection{Abordagem Neoliberal}

Nesta perspectiva, convencionou-se denominar de neoliberalismo à coalizão sócio-econômica e política reunida em torno da redução da intervenção do Estado na economia e da desregulamentação dos mercados. Tais medidas iriam ao encontro de interesses não somente das empresas transnacionais, mas também do mercado financeiro internacional ${ }^{85}$. Esta coalizão está relacionada à difusão de um pensamento econômico neoliberal de forte influência na política e na sociedade em todo o mundo, cuja doutrina tem por razão central as reformas do Estado, com fortes conseqüências negativas para as políticas sociais de natureza assistencial e para a política econômica e de emprego, comprometendo assim os direitos dos cidadãos.

Na discussão sobre a economia informal, esta corrente é representada na América Latina por HERNANDO DE SOTO ${ }^{86}$, um dos primeiros expoentes da vertente neoliberal. Nessa perspectiva, a existência do setor informal estaria relacionada a uma atividade econômica popular, que se contrapõe ao Estado e a suas regulamentações excessivas sobre a economia. O Estado deveria retirar-se, relaxar as amarras e possibilitar assim o livre funcionamento do mercado. Livre de interferências, o mercado seria capaz de dar cabo das distorções atuais, que tal abordagem associa com a presença

84 THEODORO, Mario (2002). O Estado e os Diferentes Enfoques sobre o Informal. Brasília, IPEA, novembro de 2002, Texto para Discussão nº 919. 85 IANNI, Octavio.(2001). A Era do Globalismo. Rio de Janeiro, Civilização Brasileira, pp. 215-235. 
do Estado. Esta visão se contrapõe de maneira clara à posição da Organização Internacional do Trabalho (OIT) e do PREALC sobre a economia informal.

$\mathrm{O}$ autor apresenta o setor informal como o "derradeiro bastião do empreendedorismo capitalista". Os verdadeiros empreendedores representariam uma nova classe, que seria responsável por uma revolução que recolocaria os países da América Latina no rumo do desenvolvimento. Para os neoliberais, o informal seria algo que extrapolaria o campo do mercado de trabalho. A idéia de informalidade diria respeito a tudo que se encontra à margem da legislação, seja no que tange ao mercado de trabalho, seja em outros domínios - caso da habitação e do Direito.

A forte intervenção estatal na economia, em particular a regulação que o Estado exerce no mercado do trabalho, desestimularia a contratação de mão-de-obra pelas empresas, possibilitando o surgimento de empresas ilegais. Este enfoque tem se manifestado nos países em que predomina a política neoliberal. Nesta perspectiva, convencionou-se denominar de neoliberalismo à coalizão sócio-econômica e política já citada anteriormente, em defesa da redução da interferência do Estado na economia e da desregulamentação dos mercados, que representaria interesses não somente das empresas transnacionais, mas também do mercado financeiro internacional, como o FMI e Banco Mundial.

Assim, o critério jurídico da legalidade das empresas perante o Estado identifica apenas dois tipos de mercado: o formal e o informal. Sendo assim, a carteira de trabalho assinada é um dos principais elementos que definem a participação em condições normais dentro do mercado formal. O contrato legal de trabalho instaura ao trabalhador direitos e deveres previstos na legislação trabalhista. Já a economia informal possui um caráter invisível, subterrâneo, submerso e sem qualquer aparato jurídico institucional do mercado de trabalho formal, reconhecido oficialmente. Os partidários dessa visão 
defendem a desregulamentação da economia, a redução do tamanho do Estado e as atividades ilegais.

A hipótese predominante nas décadas de 70 e 80 sobre o trabalho informal estava relacionada com alguns aspectos da visão neoliberal. Nesse sentido, o setor informal era visto como uma espécie de "amortecedor" do setor formal - a informalidade crescia em tempos de crise e diminuía em períodos de expansão da economia, funcionando, portanto, de maneira anticíclica ${ }^{87}$. O setor informal tenderia a diminuir em resposta ao crescimento da economia e o movimento de entrada e saída na informalidade seria regra, e não exceção, pois o mercado de trabalho era entendido como flexível. A informalidade seria um status transitório e não permanente. $\mathrm{O}$ que podemos constatar nos tempos atuais é que o setor informal possui caráter permanente e tendência à expansão devido ao crescimento do desemprego, causado pela globalização da economia.

CACCAMALI distingue a informalidade propriamente dita da economia submersa, subterrânea ou invisível. A primeira seria a denominação para o conjunto das atividades econômicas em que não há uma separação nítida entre capital e trabalho, mantendo a conceituação original da OIT (1972); a segunda seria a denominação para atividades econômicas que fogem da regulação do Estado, isto é, ilegais.

Dessa maneira, haveria uma superposição entre as atividades informais e as subterrâneas. A submersão seria mais relevante entre as atividades informais do que nas formais. A informalidade seria uma continuação do setor formal, não havendo segmentação mercado de trabalho entre formais e informais. A presença do indivíduo no setor informal seria resultado de uma escolha, motivada pela flexibilidade das condições de trabalho no setor informal e dos elevados custos incidentes sobre a

87 Destaca-se que o comportamento da renda no setor informal é cíclico, pois acompanha a evolução da renda do setor formal. 
contratação formal $^{88}$. Uma outra hipótese aponta para as características das firmas, isto é, parcela substancial dos indivíduos trabalhando em condições de informais se encontra em negócios que atuam à margem da lei, sendo eles próprios são informais do ponto de vista tributário e de outras obrigações legais exigidas das firmas legais. Sendo assim, as causas da informalidade seriam: elevada carga tributária, custos fixos, desinformação, baixo acesso à tecnologia e mercados de trabalho incompletos ou concentrados, entre outros motivos.

Uma crítica recorrente à visão neoliberal aponta para fragilidades expostas quando o mercado é liberado da intervenção estatal. A falta de uma política de fortalecimento do setor informal dificulta a proposta de redução dos custos trabalhistas para incluir trabalhadores informais na formalidade ${ }^{89}$. Percebe-se que, apesar do significado dos empreendimentos de pequeno porte nas áreas metropolitanas, não ocorreu uma organização social do setor informal que resultasse em um programa nacional de incentivo e fortalecimento da economia informal. Talvez a própria característica da atividade ocupacional da categoria dificulte a organização dos trabalhadores. Percebe-se que as instituições representativas, como associações e sindicatos dos camelôs ou vendedores ambulantes, não possuem reconhecimento social e tradição de luta em defesa da categoria. Destacam-se algumas iniciativas, como a do Movimento Unidos dos Camelôs do Rio de Janeiro (MUCA), que já obteve repercussão na mídia a, da luta por moradia na cidade junto com outros movimentos sociais - como o Movimento dos Trabalhadores Sem-Teto e o Movimento dos Moradores de Rua - e costuma estar presente em várias ocupações de imóveis abandonados. É notória a

88 ARBACHE, Jorge Saba (2003). Pobreza e Mercados no Brasil. IN: CEPAL. Pobreza e Mercados no Brasil: uma análise de iniciativas de políticas públicas. Brasília, CEPAL, Brasil pp.9-62. 
presença significativa de camelôs, vendedores ambulantes e de outros trabalhadores informais dentre os moradores de ocupações urbanas ${ }^{90}$.

Apesar desta iniciativa ser importante, analisamos que o MUCA possui caráter principalmente defensivo, identificado na forma de protestos, paralisações e combates, mas encontra dificuldades para uma mobilização e organização dos camelôs enquanto "classe trabalhadora". Percebe-se neste caso o que ANTUNES ${ }^{91}$ descreve como a "classe que vive do trabalho", isto é, um conjunto de sujeitos sem uma identidade definida enquanto "classe proletária", segundo o conceito de Marx.

Pode-se supor que o motivo da ausência de organização seria a falta de uma identificação dos trabalhadores informais ou de empreendedores familiares de pequeno porte enquanto categoria social. A existência de categorias profissionais extremamente diversificadas e heterogêneas dificulta a formação de uma identidade profissional. Além disso, os desempregados e os trabalhadores informais não se identificam com os referenciais de classe dos trabalhadores organizados em sindicatos, que não os representam plenamente. Outro ponto a considerar é que ainda não existe um sujeito social e político representando as amplas camadas sociais da economia formal que tenha poder de negociação política para elaborar um programa nacional voltado ao setor informal $^{92}$.

MENEZES Filho, MENDES e ALMEIDA, à partir de pesquisa empírica, afirmam que "condicional ao nível de escolaridade, os salários da economia informal são maiores do que os da economia formal, indicando que a proteção legal gozada pelos trabalhadores do setor formal não lhes garante um maior nível salarial. Embora o setor formal garanta vantagens como férias, fundo de garantia, estabilidade no emprego e

90 Conforme depoimento concedido pela líder do Movimento Unidos dos Camelôs de Rio de Janeiro (MUCA), Maria de Lourdes (Maria do Camelô). 91 ANTUNES, Ricardo (2000). Sentidos do Trabalho. São Paulo: Ed. Boitempo. 
contribuição previdenciária patronal, tais vantagens parecem ser compensadas no setor informal por remuneração adicional".

Além disso, a existência do viés de auto-seleção indica que, condicional ao nível de escolaridade, o diferencial de salários observados entre formais e informais decorre, na verdade, da melhor qualidade da força de trabalho empregada no setor formal. Os autores favoráveis à desregulamentação afirmam não existir o fenômeno da segmentação no mercado de trabalho brasileiro, entendido como a existência de postos de trabalho com qualidade diferente, isto é, trabalhadores que são substitutos perfeitos ganhando salários diferentes. Essa vertente defende que a "política eficiente de elevação dos salários reais passa pela melhor qualificação dos trabalhadores e não pela criação de leis que garantem benefícios trabalhistas" $" 93$. Neste caso, os autores estão negando as desigualdades sociais existentes em relação ao acesso à educação e à qualificação profissional.

Fazemos aqui uma crítica ao enfoque neoliberal que defende a flexibilização do mercado de trabalho. Percebemos que as empresas fazem uso desse artifício para manter vínculos de trabalho atípicos, em que os trabalhadores não possuam garantia plena de trabalho e não sejam respeitados em seus direitos. A informalidade, neste caso, significa um conjunto de relações e condições de trabalho precárias em que se confirma cada vez mais a exploração exercida pelas empresas.

A abordagem que criticamos analisa, portanto, a economia informal como anticíclica, subordinada, e intersticial, nega a existência de segmentação no mercado de trabalho brasileiro e defende a desregulamentação da economia e do mercado de trabalho, bem como a retirada do Estado do seu papel de produtor, regulador e indutor

93 MENEZES FILHO, Naércio; MENDES, Marcos; ALMEIDA, Eduardo (2004). O Diferencial de salários formal-informal no Brasil: segmentação ou viés de seleção? RBE, Rio de Janeiro, 58(2), abril-junho, pp. 235-248. 
do desenvolvimento. A flexibilização das leis trabalhistas e a qualificação dos trabalhadores seriam soluções para incentivar a formalização dos informais.

\subsubsection{Abordagem Estruturalista}

O enfoque estruturalista é sustentado por dois paradigmas: o marxismo e o keynesianismo. A tradição keynesiana está representada na América Latina pelos desenvolvimentistas, concentrados na CEPAL, no Programa Regional de Emprego para a América Latina (PREALC) e na OIT. Estes defendem um papel ativo do governo na promoção do desenvolvimento econômico, a partir da ação determinada do Estado por meio de investimento público e estímulo ao capital privado para investir em setores estratégicos da economia. Por outro lado, não defendem a promoção do rápido crescimento econômico mediante a abertura da economia para capitais e mercadorias do exterior, bem como a desregulamentação do mercado de trabalho.

O principal conceito da escola cepalina é o de heterogeneidade estrutural. Este conceito diz respeito à coexistência de formas produtivas e relações sociais correspondentes a diferentes fases e modalidades do desenvolvimento da região que, sendo interdependentes em sua dinâmica, convivem no interior dos Estados politicamente unificados. O conceito de heterogeneidade estrutural denota uma situação na qual existem grandes diferenças de produtividade e modernidade entre os setores de atividades econômicas. Percebe-se que tanto as formas produtivas, quanto as relações sociais, são expressas neste conceito.

A heterogeneidade estrutural, nas suas dimensões técnico-produtiva, institucional, funcional e de relações sociais, revela a convivência de distintos padrões 
tecnológicos, acarretando diferentes padrões de produtividade; demonstra diversas formas de relacionamento das camadas sociais e dos setores produtivos com o Estado; revela ainda as diversas relações de funcionalidade que os segmentos não-capitalistas, atrasados ou informais mantêm com os núcleos dinâmicos de acumulação de capital; e por último, demonstra também diferenças nas formas de apropriação do excedente, na estrutura ocupacional e nos padrões de distribuição de renda e de acesso aos bens públicos das diversas camadas sociais ${ }^{94}$.

Neste contexto, a heterogeneidade estrutural seria a conceituação de uma descontinuidade entre as camadas "moderna" e "tradicional" da economia, decorrente das diferenças de produtividade. Os estruturalistas perceberam que a concentração dos frutos do progresso técnico apenas acentua as tendências de marginalização de segmentos da população e da estrutura produtiva em relação ao "pólo moderno", embora se reconheça que as camadas sociais e os componentes da estrutura produtiva estão inseridos num mesmo contexto.

O estilo de desenvolvimento na América Latina não conduz a uma homogeneização da estrutura global da economia, mas aprofunda a sua heterogeneidade estrutural. A periferia latino-americana participa da sociedade global, mas sem chegar a integrá-la em seu nível básico, isto é, em termos econômicos de disseminação do progresso técnico, do aumento da produtividade e da renda, da ampliação e elevação das oportunidades de emprego, etc. Contudo, os setores modernos da economia regional adquirem autonomias internas, facilitadas pelo diferencial tecnológico, tendendo a crescer apoiados em suas próprias forças, estabelecendo circuitos próprios de receita, investimento e despesa. $^{95}$

94 COMIN, Álvaro (2003). O Dualismo Revisitado. IN: COMIN, Álvaro. Mudanças na Estrutura Sócio-Ocupacional do Mercado de Trabalho em São Paulo. São Paulo, FFLCH - USP (Tese de Doutorado).

95 PINTO, Aníbal (2000). Natureza e Implicações da Heterogeneidade Estrutural na América Latina. IN: BIELSCHOWSKY, Ricardo (org). Cinquenta anos de pensamento na CEPAL. Rio de Janeiro, Record, pp. 569 -588. 
É no caráter dual do subdesenvolvimento latino-americano que se estrutura a tradição cepalina, com análises sobre a informalidade diferentes da interpretação neoliberal. A informalidade, que é associada à precariedade tecnológica e organizacional, à baixa produtividade e mesmo à pobreza e à marginalidade, decorreria do caráter periférico das formações capitalistas, nas quais sobrevivem traços précapitalistas. Nesse sentido, existem três tipos de atividades informais que não se excluem mutuamente e que são os seguintes:

1. De sobrevivência: as atividades econômicas informais podem ter por a sobrevivência de uma pessoa ou domicílio, por meio da produção direta com fins de subsistência, ou mera venda de bens e serviços no mercado;

2. De exploração: as atividades econômicas informais podem estar orientadas para melhorar a flexibilidade da gestão e reduzir os custos trabalhistas das empresas do setor formal, por meio de contratação informal de trabalhadores ou da sub-contratação de empresários informais;

3. De crescimento: as atividades econômicas informais podem estar organizadas por pequenas empresas com o objetivo de acumular capital, aproveitando as relações de solidariedade que possam existir entre elas, a maior flexibilidade e os menores custos.

Rosenbluth $^{96}$ defende as idéias da CEPAL e do PREALC de que o desenvolvimento econômico, as políticas públicas de qualificação de mão-de-obra, os incentivos aos pequenos empreendimentos e o fortalecimento das diversas instituições poderão diminuir o número de trabalhadores informais submetidos a condições de vida 
precária e instável. Por outro lado, para o autor, os níveis e as modalidades de desenvolvimento dos países latino-americanos, caracterizados pela incorporação de tecnologia importada, geração de empregos insuficientes e estrutura de preços inelástica é que não permitiriam repassar aos consumidores os aumentos da produtividade, determinando os aspectos quantitativos e a qualitativos da informalidade. Esta estaria relacionada com o funcionamento da economia e seria componente da pobreza da grande maioria dos informais. $\mathrm{O}$ autor correlaciona informalidade com pobreza ${ }^{97}$, pois $\mathrm{o}$ desemprego aberto e o sub-emprego seriam "fatores determinantes da pobreza". Nesta análise, o "estilo de desenvolvimento econômico" de cada país seria o fator determinante da informalidade.

RAÚL PREBISCH e ANÍBAL PINTO, do PREALC, têm contribuído para o enriquecimento desta corrente analítica. Para os autores, a origem do setor informal se relaciona aos seguintes motivos:

1. À geração de emprego insuficiente para absorver o alto crescimento da força de trabalho - situação que se agrava nos períodos de crises, quando se expulsam trabalhadores de seus empregos;

2. À instabilidade ocupacional se origina pelo comportamento irregular de determinadas atividades, como a agricultura e a construção, e pela vida curta das pequenas e médias empresas, que sofrem com a instabilidade econômica;

3. Ao excedente de mão-de-obra, que contribui para aumentar o número de trabalhadores por conta própria, principalmente nos ramos de serviços e de reparação, e dos que se encontram nas

97 Para Rosenbluth "a maior parte dos pobres pertence ao setor informal, o que não significa que todos os informais são pobres" . 
pequenas unidades produtivas urbanas (micro e pequenas empresas). As grandes empresas transferem parte de sua produção para as pequenas empresas para reduzir custos ${ }^{98}$. As unidades produtivas de menor porte, importantes em termos de geração de emprego, satisfazem apenas uma pequena porção da demanda efetiva, reforçando a tese de que a maioria dos informais é marginal e produtos do funcionamento econômico ${ }^{99}$.

É nessa abordagem que se encontram as maiores justificativas para a ação intervencionista do Estado por meio de políticas específicas, dirigidas ao setor informal. As políticas e programas para este setor constituem o principal foco da vertente cepalina, presente na visão dominante e intervencionista, de forte influência sobre órgãos públicos, como Ministério do Trabalho, BNDES e secretarias estaduais do Trabalho, entre outros.

Nesse caso, a economia informal está ligada a instituições estatais, Organizações Não-Governamentais (ONGs) e organismos internacionais. No Brasil, temos como exemplo o Programa de Economia Solidária em Desenvolvimento ${ }^{100}$, do Ministério do Trabalho e Emprego, que marcou a introdução de políticas públicas voltadas a ações de inclusão, proteção e fomento aos trabalhadores que tenham relações de trabalho distintas do emprego assalariado. As iniciativas no campo da economia solidária procuram apontar soluções à falta de trabalho e renda em âmbito nacional, num contexto de novas realidades do mundo do trabalho.

\footnotetext{
98 ROSENBLUTH, Guillermo (1994). Informalidad y Pobreza em América Latina. Revista de la CEPAL, No 52, abril. 99 Idem, pg. 165.

100 O programa "Economia Solidária em Desenvolvimento" começou a ser implementado em 2004, após a criação da Secretaria Nacional de Economia Solidária, no Ministério do Trabalho e Emprego. Além da intensa interlocução com a sociedade civil, a política nacional de economia solidária também se caracteriza por apostar na transversalidade e na intersetorialidade, buscando articular-se às demais políticas de geração de trabalho e renda, de combate à pobreza e de inclusão social do Governo Federal e 
Essa forma de organização do trabalho solidário constitui um modo de produção alternativo ao Capitalismo, onde os próprios trabalhadores assumem coletivamente a gestão de seus empreendimentos econômicos. Apesar de defender os princípios de autogestão e de autonomia, percebe-se que, em muitos casos, a empresa-modelo - e portanto o tipo ideal a ser perseguido - é a moderna empresa capitalista: capitalizada, legalmente reconhecida, com acesso a crédito, alta produtividade do trabalho, bem organizada e administrada.

A análise da OIT, que toma como ponto de partida a unidade produtiva, poderia ser enquadrada nesta linha. CORAGGIO ${ }^{101}$ afirma que os objetivos dos programas baseados nesta interpretação seriam aumentar a eficiência das empresas do setor informal. Segundo o autor, esta linha de abordagem teria duas correntes:

1. Corrente individualista: a microempresa é considerada a matriz do autodesenvolvimento;

2. Corrente associativista: percebe que uma condição para o desenvolvimento econômico e social é a aglomeração de forças produtivas na forma de cooperativas ou organizações similares.

A abordagem estruturalista resgata a dimensão social e política da informalidade nos países em desenvolvimento (mais especificamente, na América Latina). A relação entre Estado e sociedade reproduziria uma forma particular de arcabouço jurídico-legal que, diferentemente dos países desenvolvidos, teria na própria existência de normas e procedimentos extralegais um dos pilares da informalidade leis e procedimentos existente, isto é - entendida, portanto, como um não-respeito das normas, leis e procedimentos impostos pelo Estado, para os defensores dessa abordagem. 
Do ponto de vista do mercado de trabalho, a informalidade se exprimiria mediante a articulação entre as relações capitalistas clássicas e o trabalho nãoassalariado. Nesta perspectiva, a não-generalização da relação salarial produziria o subemprego expressão mais concreta da informalidade.

A informalidade também estaria associada à institucionalização de uma cidadania regulada, ou seja, a um estado de direito não-generalizado para todos. Não é, portanto o excesso de Estado, mas sua incompletude, sua abrangência parcial e restrita que vai contribuir para a existência de privilégios e a reprodução da desigualdade. As leis são aplicadas não para o conjunto da sociedade, mas para uma parcela. É essa situação que diferencia a América Latina da Europa Ocidental. O trabalho precário, o clandestino, os "bicos", o pequeno negócio e as várias formas de desemprego oculto e de sub-emprego estão cada vez mais presentes também nos países desenvolvidos, mas neles, de alguma forma, existe um esforço para que estas atividades sejam enquadradas jurídica e legalmente. A diferença maior reside no caráter excludente e não-generalizado da cidadania nos países em desenvolvimento.

\subsubsection{Abordagem Marginalista}

Esta abordagem identifica a economia informal como sendo um setor marginal da economia. Segundo as correntes deste enfoque, o setor é caracterizado como pólo marginal, massa marginal ou como um conjunto de setores arcaicos, remanescentes de outros modos de produção. Os teóricos dessa perspectiva, chamados de marginalistas, discutem a categoria de superpopulação relativa, ou excedente de mão-de-obra nãoincorporado ao processo de desenvolvimento capitalista. De acordo com a divisão 
clássica marxista ${ }^{102}$, fariam parte da força de trabalho excedente, não assimiladas ao processo produtivo capitalista, as três partes do chamado exército industrial de reserva:

1. População flutuante ou líquida: está relacionada com os movimentos de expansão e retratação da atividade econômica do sistema capitalista (desemprego aberto);

2. População latente: trata-se da liberação de mão-de-obra rural pela penetração do capitalismo no campo (campesinato nãocapitalista), sendo também constituída pelos trabalhadores autônomos do setor terciário, os chamados trabalhadores por “conta própria”, ocupados no comércio ou em serviços;

3. População estagnada ou pauperizada: diz respeito aos setores arcaicos da economia, tais como indústria em domicílio e artesanato. É possível incluir nesta camada os trabalhadores domésticos.

Além destas três subdivisões do exército industrial de reserva, existe ainda uma quarta camada da superpopulação relativa, denominada lumpemproletariado, integrada pelos setores mais pauperizados da estrutura social, ou seja:

1. Subempregados (desemprego invisivel/trabalhadores pobres/working poor);

2. Trabalhadores em atividades ilícitas ou marginais;

3. Indigentes.

O termo "lumpemproletariado" foi utilizado por MARX para designar a camada social que vive do subemprego ou de atividades marginais, como prostituição, rufianismo (cáften), mendicância, roubo, e tráfico de drogas, entre outras. MARX 
também descreve essa camada social como sendo incapaz de qualquer ação conseqüente contra a sociedade capitalista ${ }^{103}$, diferentemente dos trabalhadores de fábricas, das indústrias e das empresas que podem ser organizados de maneira tradicional. Trata-se, portanto, de uma camada social indigente e sem consciência social.

Destaca-se que, nesse caso, é considerada a distinção entre os grandes chefes do tráfico de drogas, da prostituição e dos negócios ilícitos, que podem ser configurados como verdadeiros "empresários". Existe uma ambigüidade na percepção social destes indivíduos, que são denominados criminosos. Os trabalhadores que vivem do subemprego são abordados em alguns estudos ${ }^{104105}$ em Sociologia do Trabalho e na área de saúde do trabalhador. A maioria dos autores aborda as condições de trabalho e de saúde, por exemplo, nas indústrias, nos serviços e na agroindústria, em que existe maior organização sindical dos trabalhadores.

MARX afirma que a reprodução da força de trabalho constitui de fato um momento da própria reprodução do Capital, sendo que a acumulação de capital consiste na multiplicação do proletariado; por outro lado, também refere que os movimentos de expansão e contração da produção da indústria moderna liberam constantemente parte dos trabalhadores, transformando-os em desempregados e sub-empregados. O processo de acumulação de capital, portanto propicia um aumento do proletariado e da massa de trabalhadores que não consegue emprego. Desta maneira, a produção da superpopulação relativa se dá por dois fenômenos: 1) porque a demanda de trabalho não é idêntica ao crescimento do capital; e 2) porque a oferta de trabalho não é idêntica ao crescimento da classe trabalhadora ${ }^{106}$.

103 MARX, Karl. (1978). O 18 do Brumário e Cartas a kugelmann. Rio de Janeiro, Ed. Paz e Terra. 104 CERQUEIRA, Monique Borba ( 2000). Os Guardiões do Tempo Sobrevivem à Cidade Veloz. Trabalho Informal e Saúde. Dimensões da Exclusão Social. Dissertação de Mestrado. Departamento de Sociologia do Instituto de Filosofia e Ciências Humanas da Universidade Estadual de Campinas, Campinas/SP. 105 IBANHES, Lauro César (1999). O Setor Informal Urbano : a Organização e as Condições de Saúde de um Grupo de Vendedores Ambulantes. Tese de Doutorado. Faculdade de Saúde Pública da Universidade de São Paulo. 106 MARX, Karl ( 1988), Op. Cit, p. 179-192. 
Segundo MARX, todo trabalhador parcial ou inteiramente desocupado faz parte da superpopulação relativa. Esta se divide em líquida (flutuante), latente e estagnada. Contudo, para MARX, o mais profundo sedimento da superpopulação relativa habita a esfera do pauperismo. Ou seja, o pauperismo, ou o lumpemproletariado, o mais profundo sedimento da superpopulação relativa, não se confunde com aqueles três segmentos citados acima. Percebemos que MARX inclui trabalhadores pobres (aptos para o trabalho) no lumpemproletariado, além de crianças, mendigos e doentes, entre outros. Ou seja, trata-se de uma camada de trabalhadores que não faz parte do exército industrial de reserva, embora faça parte da superpopulação relativa.

Para $\mathrm{NUN}^{107}$, o exército industrial de reserva, que consiste no excedente de trabalhadores determinado pelas relações de produção, seria em Marx um efeito funcional da superpopulação relativa. Segundo o autor, a superpopulação relativa é uma categoria transitória, que coincide apenas parcialmente com o exército industrial de reserva.

NUN faz uma análise dos efeitos funcionais e a-funcionais da superpopulação relativa, introduzindo o conceito de massa marginal, com base em três transformações num tempo posterior a MARX: 1) a passagem para o modo-de-produção monopolista; 2) o significativo impulso que adquiriu a internacionalização do Capital; e 3) as modificações que ocorreram na estrutura ocupacional. O argumento de NUN é que os mecanismos de geração da superpopulação relativa se pluralizam devido à crise do modelo fordista, isto é, a desestruturação generalizada das relações de trabalho, que se tornaram heterogêneas e instáveis.

O conceito de massa marginal seria então o segmento de superpopulação relativa ligado ao setor produtivo mediante relações afuncionais ou disfuncionais. 
Assim, apesar de ser gerada pelo processo produtivo, a massa marginal não é absorvida pelo mesmo, diversamente do exército industrial de reserva.

NUN $^{108}$ não entende o processo de acumulação como sendo autônomo ou possuindo uma lógica própria. Pelo contrário, o vê como necessitando de um amplo conjunto de instituições sociais (estruturas políticas e ideológicas) que o viabilize. Configura-se mais como um regime social de acumulação, onde a acumulação de capital aparece sempre como o resultado contingente de uma dialética de estruturas e de estratégias e táticas específicas de acumulação. Isto é, o crescimento não é um processo meramente econômico.

Para NUN ${ }^{109}$, isso não significa o fim do trabalho, como fazem alguns teóricos. Enquanto fator de produção, o trabalho é necessário ao processo de acumulação capitalista. O autor comenta que na América Latina nunca existiu uma sociedade salarial e um estado de bem-estar social constituído, como ocorreu na Europa. Desta maneira, não cabe afirmar o fim do trabalho assalariado na região. No entanto, devido às transformações na economia, pode-se considerar como fato o fim da possibilidade de generalização do trabalho assalariado bem-remunerado e estável para a população.

Nos países em desenvolvimento, portanto, os desempregados que não contam com os mecanismos de proteção social ainda existentes na Europa podem atuar como exército industrial de reserva no "setor competitivo" e como massa marginal no "setor monopolístico" da mesma economia capitalista. NUN ${ }^{110}$ afirma que a população excedente pode ser irrelevante para o setor hegemônico da economia, ou pode até mesmo se tornar um perigo para sua estabilidade.

108 NUN, José (1999) 
Seguindo uma interpretação relativamente próxima, QUIJANO ${ }^{111}$ denomina população marginalizada à população excedente de trabalhadores que, expulsa do trabalho assalariado estável, não foi incorporada ao mercado pela alternância de ciclos de expansão e contração do capital. No entanto, diferentemente de NUN, o autor afirma que essa mão-de-obra excedente tende a formar um pólo marginal na economia, que também tem seu funcionamento à parte do processo de acumulação capitalista.

"Un conjunto de ocupaciones o actividades estabelecidas en torno del uso de recursos residuales de producción; que se estructuram como relaciones sociales de modo precário e inestable; que generan ingresos reducidos, inestables y de incompleta configuración a respecto del "salário" o de la "ganancia"; que producen bienes y o servicios para um mercado constituído por la propia población de trabajadores 'marginalizados'. En suma, el nível más dominado de la estructura de poder del capital". 112

Dessa maneira, pólo marginal é um conjunto de atividades econômicas, uma rede de relações sociais e um nível de recursos e de produtividade dentro do poder capitalista, porém marginal. A informalidade não seria uma característica de um setor do trabalho dentro do capitalismo, mas uma característica de um setor do Capital.

Os desempregados e os subempregados tendem a constituir um complexo de atividades econômicas e de formas de organização com níveis de recursos, tecnologia e produtividade característica. O pólo marginal é um complexo de atividades econômicas (não somente limitadas ao emprego no mercado de trabalho) constituído dentro do poder capitalista, cuja característica principal é o trabalho. Organiza-se, dessa forma, sem empresas e sem capitalistas, como uma "economia alternativa ou popular".

111 QUIJANO, Aníbal ( 1998) . La Economia Popular y sus Caminos em América Latina. Lima Mosca Azul. 112 Idem,Op.Cit,,p. 70 
Por um lado, NUN admite lógicas diferentes dentro do próprio sistema capitalista; por outro lado, QUIJANO admite uma lógica não-capitalista dentro do sistema capitalista, sem atribuir-lhe qualquer capacidade de transformação. Tanto na análise de NUN da massa marginal, quanto no enfoque de QUIJANO do pólo marginal, a marginalidade assume o lugar do exército industrial de reserva, no contexto do mundo subdesenvolvido e na fase monopolista do Capitalismo, sem que isto signifique uma transformação qualitativa do sistema.

Segundo o QUIJANO, no setor informal existiriam diversos tipos de atividade econômica, como:

1. Empresários capitalistas formais, cujas empresas operam com trabalhadores informais;

2. Empresários cujas empresas são informais, juntamente com seus empregados;

3. Trabalhadores e suas famílias, que vendem sua produção para empresas formais ou informais.

Sendo assim, o autor traça algumas definições:

1. Venda informal de trabalho (pequena produção mercantil), composta pelos trabalhadores ou famílias que produzem ou vendem, independentemente de contratos ou acordos com empresários formais ou informais;

2. Venda comunitária de trabalho (reciprocidade), os trabalhadores ou famílias que se associam com instituições para subsistir na base do intercâmbio de trabalho, sem passar pelo mercado (reciprocidade); 
3. Pólo marginal propriamente dito, composto pelos trabalhadores ou famílias que operam de modo independente, com recursos e produtividade que apenas lhes permite subsistir.

KOWARICK $^{113}$ aproxima sua análise desta visão e analisa as sociedades latinoamericanas para "categorizar novos processos que geram marginalidade decorrentes do fato de o sistema além de capitalista, ser também dependente". O autor não nega a existência de marginalidade nos países desenvolvidos e afirma que há um "novo tipo de desenvolvimento (ou subdesenvolvimento), que tem por característica a qualidade de ser superexcludente e de estar articulado à criação e manutenção de relações de produção de características arcaicas”. Além do desemprego, percebemos coexistirem neste setor marginal o subemprego e as ocupações e formas de trabalho não propriamente capitalistas que alimentam o sistema.

"Na América Latina, (...), há uma larga fatia populacional que não consegue se inserir no sistema produtivo, engrossando o rol dos desempregados ou inativos; bem como razoável proporção da força de trabalho que não consegue estabelecer-se como assalariada, permanecendo numa situação de subemprego, de modo particular nas ocupações autônomas do setor terciário, ou ainda vinculada às atividades artesanais e à indústria a domicílio. Tais fenômenos são largamente analisados no quadro da teoria da acumulação capitalista e no contexto latinoamericano, em função do caráter dependente da economia e da sociedade dos países da Região"114.

113 KOWARICK, Lúcio (1975). Capitalismo e Marginalidade na América Latina. Rio de Janeiro, Ed. Paz e Terra, pp. 61-62. 114 Op. Cit, p. 65 
Nessa dinâmica capitalista de criação e manutenção de relações não-capitalistas, delineada por KOWARICK ${ }^{115}$, percebemos que a "lógica estrutural de tipo capitalista" promove atividades não tipicamente capitalistas, que integram o processo de acumulação, conforme o trecho a seguir:

"Em outros termos, o capitalismo da Região desenvolve-se transformando pequena parcela da força de trabalho em trabalhadores assalariados: ao se desenvolver, libera parte da mão-de-obra vinculada às relações de produção "tradicionais", que não consegue se transformar em assalariada. Mas esta "liberação" não é aleatória. Ela é criada com a intensificação do processo industrial, dando origem a vastas parcelas de mão-deobra que passam a operar sob 'novas' relações de produção 'arcaicas', presentes em boa parte das atividades integrantes do setor terciário da economia ${ }^{116}$ (...) E o mais importante é que tanto a manutenção destas formas 'tradicionais', como a criação de 'novas' são parte integrante de um modo de produção que, não obstante ser em sua dinâmica essencial de corte nitidamente capitalista, no processo de sua acumulação, as articula e delas se alimenta $^{117,}$.

Para KOWARICK ${ }^{118}$, não se trata de duas estruturas, uma "moderna" e outra "tradicional", ou "arcaica", uma "marginal" e outra "integrada". Assim, "trata-se de uma única lógica estrutural, de tipo capitalista, a qual ao mesmo tempo gera e mantém

\footnotetext{
115 KOWARICK, Lúcio (1975).

116 Kowarick detalha o setor terciário da economia especificando as "ocupações autônomas do comércio de mercadorias, os pequenos serviços de reparação e manutenção e os empregos domésticos remunerados, além dos desempregados, e as várias formas de subempregos e trabalhadores ocasionais ou intermitentes que caracterizam o cenário urbano de trabalho das sociedades latino-americanas". Segundo o autor "ao se desenvolver, o capitalismo não chega a desarticularas formas tradicionais de produção, cujos exemplos típicos são as economias de subsistência do setor agrícola, o artesanato tanto rural como urbano, a indústria a domicílio que, em alguns países da região(América Latina) continuam a persistir .

117 Op. Cit., p. 61

118 KOWARICK, Lúcio (1975).
} 
formas de inserção na divisão social do trabalho não tipicamente capitalista que longe de serem um peso morto constituem partes integrantes do processo de acumulação" ${ }^{119}$.

O autor ressalta que a situação de dependência é central na forma de acumulação que marca os países latino-americanos. Nessa perspectiva, as contradições que geram marginalidade estariam no próprio capitalismo, mas seriam acirradas pela dependência estrutural das nossas sociedades. Desta maneira, percebe-se um processo de desenvolvimento com maiores desigualdades sociais, onde a marginalidade é funcional à estrutura do sistema capitalista.

KOWARICK critica as abordagens de QUIJANO e de NUN, afirmando que se torna "falacioso" se falar de "pólo marginal" ou de "massa marginal" da economia, ou de "mão-de-obra marginalizada". Entretanto, procura separar os trabalhadores "nãomarginais" dos "marginais", distinguindo assim o trabalho organizado em contexto empresarial do trabalho autônomo, ou das "modalidades produtivas arcaicas". Para o autor, os trabalhadores marginais, compreendidos nas formas arcaicas de produção, poderiam ser caracterizados como superexplorados, na medida em que a exploração se dá aí de forma extensiva. Assim, a superexploração acontece somente nas formas arcaicas de produção. Mesmo na hipótese desses grupos marginais estarem auferindo mais renda que os assalariados, eles não deixariam de ser superexplorados. $\mathrm{O}$ importante não é tanto o montante de remuneração que decorre de um trabalho, mas as condições técnicas e sociais em que o trabalho se realiza.

Dessa maneira, as populações marginais não são necessariamente os pobres ou os indigentes, nem fazem parte do "lumpen". Para KOWARICK ${ }^{120}$, a marginalidade é composta por categorias sociais "excluídas", presente nos "níveis mais baixos" da economia. Sendo assim, não se pode mais equacionar o trabalho marginal enquanto

119 Op Cit.,p. 61 
formas específicas de inserção nas estruturas produtivas, mas sim como mecanismos que levam em últimas instâncias na pauperização. O autor, portanto discorda da forma dicotômica de articular o modelo econômico entre "setores marginais" e "setores evoluídos" e defende o esquema marxista clássico de divisão do exército industrial de reserva entre população flutuante, estagnada e latente e critica as formulações teóricas sobre massa marginal e mão-de-obra marginalizada e pólo marginal.

A abordagem marginalista pode estar relacionada com a proposta da construção de uma economia popular. CORAGGIO ${ }^{121}$ ressalta o potencial de transformação e de mobilização política existente no setor informal. $\mathrm{O}$ autor defende a idéia de integração entre a política, a cultura e a economia popular. Além disso, faz uma crítica ao modelo neoliberal e ressalta a importância de criar novas formas de poder e de Estado (governo popular) e estratégias de acumulação alternativa. As práticas econômicas são organizadas por meio dos movimentos sociais; redes de solidariedade; organizações não-governamentais; cooperativas e da economia doméstica, entre outros pólos.

\subsubsection{Abordagem Solidarista ou da Economia Popular}

A Abordagem Solidarista ou da Economia Popular, segundo CORAGGIO, refere-se ao setor informal como economia popular e não-capitalista, na qual se encontram os pobres; os pequenos estabelecimentos; a mão-de-obra intensiva; a baixa produtividade; o pequeno comércio; os artesanatos; a economia doméstica; uma capacidade de acumulação irrelevante; a relação de parentesco como o principal tipo de relação de produção e a solidariedade como valor predominante. A informalidade está

121 CORAGGIO, José Luis. Del Sector Informal e La economía popular. Nueva Sociedad, pp. 118 - 131 
entrelaçada com a economia subterrânea e a ilegalidade na heterogeneidade estrutural. O trabalhador informal é considerado um agente econômico independente, que não pertence à classe trabalhadora, mas está submetido a formas indiretas de subordinação ao capital. As abordagens Solidarista e pró-construção de uma economia popular são descritas por CORAGGIO, conforme trecho a seguir:

1. Abordagem solidarista: ligada às correntes cristãs e às organizações religiosas. Esta corrente parte da "economia dos pobres" e de suas estratégias familiares e comunitárias de sobrevivência, incentivando a auto-organização baseada em valores de reciprocidade e de solidariedade. Percebe-se uma relação de desconfiança com o Estado e os partidos políticos. O setor informal deveria ser reconhecido como uma economia dos pobres e estruturado a partir de estratégias locais e comunitárias.

2. Abordagem pró-construção de uma economia popular: que relaciona a informalidade ao conceito de economia popular defendido pelo próprio CORAGGIO e discutido neste texto. A economia informal seria uma alternativa popular de desenvolvimento sócio-econômico. O setor informal ampliado seria uma economia doméstica, com caráter não-capitalista, que evoluiria na direção da construção de uma economia popular. 


\subsubsection{Abordagem do Desenvolvimento e Subdesenvolvimento Capitalista}

Esta abordagem situa a economia informal como produto e parte integrante do próprio desenvolvimento capitalista, em contraposição às teses neoliberais, estruturalistas e marginalistas. Tal enfoque entende que o desenvolvimento do capitalismo é responsável pelos processos de marginalidade e informalidade. SINGER, em sua análise, ressalta que o setor informal é gerado por processos capitalistas de desenvolvimento econômico como a globalização econômica, que produz o desemprego e a exclusão social de milhares de trabalhadores ao redor do mundo.

SINGER $^{122}$ também analisa a obra de QUIJANO e critica a divisão da economia capitalista num setor "marginal" e outro "monopolístico". O autor discorda da visão dicotômica, porém não nega que as diferenças entre setores e ramos econômicos podem ocorrer devido à composição orgânica do capital, ao custo da reprodução da força de trabalho e ao tamanho da demanda. Ressaltamos o seguinte comentário:

"Não se justifica, porém, supor que o conjunto das atividades que não integram o setor monopolístico apresenta estas características de 'marginalização'. Antes pelo contrário, a expansão do setor monopolístico cria, direta ou indiretamente, condições para a multiplicação de atividades competitivas inegavelmente prósperas, onde a acumulação do capital se processa mediante a exploração extensiva de trabalhadores pouco qualificados ${ }^{123}$,

122 SINGER, Paul (1973). "Urbanização, Dependência e Marginalidade na América Latina”. In: SINGER, Paul. Economia Política da Urbanização. São Paulo, Brasiliense, pp. 63-90. 123 Op Cit., pp. 87 - 88 
Segundo SINGER, faz-se necessário aprofundar a análise das relações causais entre dependência e marginalidade, na qual "a dependência deixa de ser a principal fonte de determinação social para se tornar um entre vários fatores que influem no desenvolvimento, na urbanização e na marginalização em sociedades como as latinoamericanas". Desta maneira, não deveríamos atribuir ao imperialismo ou à dependência processos que são apenas capitalistas. Assim, não há um setor da economia que seja marginal, mas sim, são os trabalhadores os marginalizados.

SINGER reconhece três mecanismos de acumulação no Capitalismo contemporâneo:

1. A acumulação estatal gera empregos, principalmente na prestação de serviços de consumo coletivo, tais como saúde e educação tendo, portanto, uma capacidade restrita para empregar trabalhadores;

2. A acumulação capitalista é responsável, no Brasil, por quase metade dos postos de trabalho e se rege tendo em vista três finalidades: ampliar a produção, aumentar a produtividade $e$ lançar produtos novos. Este setor tem uma evidente superioridade tecnológica, o que lhe dá uma vantagem competitiva enorme;

3. A acumulação autônoma é a que se rege pela força de trabalho. A empresa familiar, isto é, a produção simples de mercadorias, tende a ser o destino do contingente humano que o aumento da produtividade e a globalização vêm expulsando das empresas capitalistas, via desemprego tecnológico e desemprego estrutural, ambos causas do empobrecimento dessa massa de trabalhadores. 
Para SINGER ${ }^{124}$, o processo de globalização reforça exclusão no mercado de trabalho, aumentando o desemprego tecnológico, decorrente da substituição de mão-deobra por máquinas importadas. No Brasil, por exemplo, tal fenômeno ocorreu a partir da abertura comercial na década de 1990. Além disso, a globalização também produz o desemprego estrutural, resultado da desindustrialização e redução de postos de trabalho em alguns países, por conta da nova divisão internacional do trabalho provocada pela Terceira Revolução Industrial.

Além do mais, um dos efeitos mais controversos dessa revolução tecnológica seria o fato dela estar descentralizando o capital $^{125}$, ou seja, as grandes empresas verticalmente integradas estão sendo coagidas pela pressão do mercado a se desintegrar, passando a comprar os produtos que antes produziam. É o que se chama terceirização. Por outro lado, as grandes empresas horizontais que operam em vários países se vêm pressionadas pela concorrência a dar autonomia às suas filiais, tomando o formato de uma rede de filiais ligadas à matriz por meio de contratos.

Essa descentralização do capital está fazendo com que pequenos empresários, trabalhadores autônomos e cooperativas de produção se conectem com o capital monopolista por meio da contratação de serviços ou da venda de produtos. O Capitalismo estaria sofrendo uma transformação radical, à medida que deixa de contratar mão-de-obra e passa a explorar a força de trabalho por outros meios: prolongando as jornadas e intensificando o volume de trabalho; diminuindo o número de empregos formais com proteção social, segurança e direitos adquiridos, garantia de salário, estabilidade, perspectiva de carreira, seguro-desemprego, seguro contra acidentes, enfermidades, velhice e morte.

124 SINGER, Paul (1996). Desemprego e Exclusão social. São Paulo em Perspectiva, vol. 10, nº 1, jan-mar, pp. 3-13. 125 SINGER, Paul (1996). 
A exclusão social do contingente humano expulso dos empregos formais em empresas capitalistas consolida-se quando passa a integrar o setor informal, definido como as atividades por conta própria, às atividades semi-legais, os "bicos", os pequenos negócios extremamente precários no que diz respeito à proteção e as condições de trabalho, deixando os seus produtores numa penumbra entre a marginalidade social e a superexploração do trabalho familiar e domiciliar, por exemplo. As atividades informais seriam, então, não completamente regulamentadas pelo Estado; ocupações nas quais o trabalho é instável, precarizado e mal remunerado; e onde a superexploração do trabalho é mais evidente, resultando numa situação social de pobreza, exclusão e marginalização dos integrantes deste setor informal.

O autor questiona se a expansão do emprego informal e autônomo resulta dos custos trabalhistas que incidem sobre a mão-de-obra registrada. SINGER contesta o enfoque neoliberal e considera que a "economia subterrânea" está se expandindo na maioria dos países, na medida em que aumenta a incidência dos fenômenos de terceirização da mão-de-obra, contratação de serviços temporários e subcontratação de pequenas empresas. O desassalariamento da força de trabalho torna-se um processo de caráter estrutural.

CASTEL $^{126}$ demonstrou que a questão social se manifesta a partir do enfraquecimento da condição salarial. A relação existente entre a precariedade econômica e a instabilidade social emerge das novas exigências tecnológicas e econômicas da evolução do Capitalismo, gerando processos que alimentam a vulnerabilidade social dos supranumerários (superpopulação relativa). Este fenômeno é sentido em praticamente todos os países desenvolvidos e em desenvolvimento.

126 CASTEL, Robert (1998). As Metamorfoses da Questão Social, uma Crônica do Salário. Petrópolis, Vozes. 
SINGER considera que o desemprego tem efeito funcional de políticas de estabilização. A concorrência intensificada entre as empresas obriga-as a reduzir custos e, portanto, a aumentar ao máximo a produtividade do trabalho, o que implica reduzir ao máximo a compra de força de trabalho. Os desempregados que antes faziam parte do exército industrial de reserva e hoje pertencem ao exército de reserva (no momento mais terciário do que industrial) desempenham o papel de mercadorias disponíveis evitando que os salários subam.

O exército reserva não se compõe apenas das vítimas do desemprego aberto que, em geral, representam uma proporção limitada da população economicamente ativa ${ }^{127}$. Ao lado dos desempregados ativos, há um outro componente do exército de reserva que são os "pobres", os socialmente excluídos que se sustentam por meio de ocupações precárias. Para o autor, estes pobres são candidatos potenciais a emprego no setor formal da economia, tão logo este expanda sua capacidade de produzir.

SINGER destaca a importância da ocupação ao lado do emprego. Ocupação compreende toda atividade que proporciona sustento a quem a exerce. $\mathrm{O}$ autor critica a idéia de que a "única maneira de alguém ganhar a vida é vender sua capacidade de produção ao capital". Ressalta a existência das múltiplas formas de atividades autônomas que, na realidade, estão crescendo no mundo inteiro e no Brasil, na medida em que o capital contém seu ritmo de acumulação e tendencialmente reduz o volume de força de trabalho. Na ausência de emprego, a ocupação seria uma saída dentro do próprio Capitalismo. O autor defende, por exemplo, o conjunto de práticas chamadas de economia solidária ${ }^{128}$.

127 No Brasil, onde o seguro-desemprego ainda é um privilégio de poucos, esta proporção dificilmente passa de 5\%. Nos países que universalizaram o segurodesemprego, o desemprego aberto costuma se situar entre 10 e 20\%.SINGER (1996), p.4. 128 Ver nota de rodapé 37 
ESTENSSORO $^{129}$ ressalta que a pobreza é um fenômeno estrutural nas sociedades latino-americanas, devido à forma de inserção da região no sistema capitalista e ao padrão de acumulação dependente destas economias. Por ouro lado, CASTEL ${ }^{130}$ refere-se a uma "nova pobreza”, causada pelo desenvolvimento recente da economia, que acentua a desigualdade social e, por sua vez, gera mais pobreza. Esta "nova pobreza" atinge também os trabalhadores formais, provocando igualmente a sua exclusão social. Contrariamente à desigualdade social e à pobreza, que são situações, a exclusão social é um processo de características multidimensionais ${ }^{131}$. Trata-se de uma acumulação de segregações, discriminações, impedimentos e vetos que vão dificultando a inclusão na sociedade e no mercado de trabalho de extensas camadas da população.

Para SINGER, melhor do que a palavra "desemprego", a noção de precarização do trabalho descreve adequadamente o que está ocorrendo: a exclusão de uma crescente massa de trabalhadores do gozo de seus direitos legais e da segurança no emprego, bem como a consolidação de um ponderável exército industrial de reserva num mercado de trabalho deteriorado. A precarização do trabalho toma a forma de relações informais ou incompletas de emprego, agravando as condições de vida dos trabalhadores. A flexibilização das relações de produção, a desregulamentação do mercado de trabalho e a precarização do trabalho fazem com que parte dos trabalhadores trabalhe mais por uma remuneração horária declinante e outra parte crescente deixe de poder trabalhar.

Observamos aqui dois aspectos: 1) a força de trabalho está sendo remunerada cada vez menos em relação ao valor do seu trabalho, isto é, ocorre uma superexploração do trabalho; e 2) os dispositivos sócio-econômicos de integração social por meio do trabalho, entendidos como emprego formal decente e agenciador de direitos, estão em

129 ESTENSSORO, Luis (2003). Capitalismo, Desigualdade e Pobreza na América Latina. São Paulo, FFLCH - USP (Tese de Doutorado). 130 CASTEL, Robert (1998). As Metamorfoses da Questão Social, uma Crônica do Salário. Petrópolis, Editora Vozes. 
crise, dado que o estatuto e os vínculos da relação salarial estão sendo questionados pelos processos e mecanismos econômicos.

CECEÑA ${ }^{132}$, após analisar as abordagens de NUN, QUIJANO e KOWARICK, as critica, afirmando que o exército industrial de reserva foi descontextualizado da totalidade capitalista e de suas determinações na tentativa de se extrair as "especificidades" do Capitalismo latino-americano. Desta forma, a acumulação capitalista deixa de conceber-se como um processo de dominação do capital, de sujeição e/ou destruição de outros modos de produção e de apropriação. Os miseráveis deixam de ser entendidos como produzidos pela desestruturação do modo de produção mais atrasado ou pelos avanços tecnológicos que sustentam o programa capitalista. Dentro de concepção marginalista desenvolver-se-iam "sub-modos" do modo de produção capitalista com dinâmicas distintas (o do capital monopólico", o "competitivo", e as variantes que o "desenvolvimento desigual e combinado" do capitalismo é capaz de gerar). Não se fala de contradição entre eles, mas de complementaridade.

Para CECEÑA ${ }^{133}$, o fenômeno observado por estes marginalistas é constituído pelos segmentos que Marx denomina de superpopulação estagnada ou pauperizada, aquelas camadas sociais que se encontram nos últimos escalões do exército industrial de reserva e que, devido a isso, somente são absorvidos em momentos de ascensão do ciclo econômico. Assim, o problema dos miseráveis aparece como fenômeno próprio da América Latina, enquanto que nos países desenvolvidos seria perfeitamente controlável, visto que aí se manifesta somente o segmento denominado por Marx de superpopulação flutuante - aqueles trabalhadores que competem diretamente por postos no mercado de trabalho, ligados às empresas capitalistas.

132 CECEÑA MARTORELlA, Ana Ester (1996). "Los Miserables em la Teoria Social Latinoamericana”. IN: MARINI, Ruy Mauro e Millán, MÀRGARA (org.) La Teoria Social Latinoamericana. México, UMA, Tomo II, pp. 237-262. 133 Op. Cit., p. 261 
Entretanto, a dinâmica de fato diferenciada das economias latino-americanas não deve ser explicada por sub-modos alternativos dentro da lógica interna do modo de produção capitalista, pois se corre o risco de comprometer a coerência da análise. $\mathrm{O}$ autor propõe a recuperação do conceito de exército industrial de reserva para abordar o problema dentro de uma perspectiva marxista, formulando a explicação da pauperização extrema por meio do conceito de superexploração do trabalho. Isto a localiza numa esfera teórica diferente dos marginalistas. A massa marginal ou pólo marginal não seria nada mais do que a superpopulação relativa pauperizada do exército industrial de reserva. Faz-se a critica à descontextualização da análise heterodoxa dos marginalistas.

MARINI ${ }^{134}$ critica o esquema de NUN e de QUIJANO, pois suas categorias de massa marginal e de pólo marginal não mantêm relação com a maneira como se polarizam as contradições de classe nas sociedades dependentes. A perspectiva da marginalidade social somente é aceita por MARINI na medida em que se incorpora à teoria marxista da dependência e aos seguintes pressupostos:

1. "A produção capitalista ao desenvolver a força produtiva do trabalho não suprime, mas acentua a maior exploração do trabalhador";

2. “As combinações de formas de exploração capitalistas se levam a cabo de maneira desigual no conjunto do sistema, engendrando formações sociais distintas segundo o predomínio de uma forma determinada".

O autor se refere ao "capitalismo financeiro globalizado". Neste contexto, Marini utiliza o conceito de superexploração do trabalho como o princípio fundamental 
do sistema subdesenvolvido. A superexploração do trabalho, na acumulação de capital do centro desenvolvido baseia-se na produção de mais-valia relativa (onde a exploração aumenta pelo barateamento das mercadorias da cesta básica dos trabalhadores) e difere da superexploração do trabalho na periferia, que se baseia na produção de mais-valia absoluta (pela abundância de força de trabalho combinada com tecnologia poupadora de mão-de-obra; pela falta de regulamentação protetora do trabalho, o que leva à extensão da jornada de trabalho; e pelo pagamento de salários abaixo do valor da força de trabalho). Marini utiliza o conceito de superexploração do trabalho em dois sentidos: a) referindo-se à redução de salários abaixo do valor da força de trabalho; e b) referindo-se ao pagamento do trabalho abaixo do nível mínimo de subsistência.

Temos então que, para a teoria marxista da dependência, o desenvolvimento das forças produtivas acentua a exploração dos trabalhadores; e que as combinações de formas de exploração capitalistas se levam a cabo de maneira desigual no sistema, configurando formações sociais distintas sob a hegemonia de uma forma determinada: o Capitalismo financeiro globalizado. Desta forma, a lei geral da acumulação capitalista consiste, nesse aspecto, do crescimento paralelo da riqueza social, ao lado do exército industrial de reserva e do lumpemproletariado. Portanto, o desenvolvimento do subdesenvolvimento é apenas a aplicação da lei geral do desenvolvimento capitalista em condições propícias criadas pela dependência estrutural.

Pode-se considerar que o trabalho informal se insere nesta lógica capitalista, pois a economia informal, neste contexto, pode ser identificada com as camadas pauperizadas do exército industrial de reserva, bem como com o lumpemproletariado (sub-emprego). A presença de trabalho instável, precário e mal remunerado em empresas semilegais, que são ainda assim empreendimentos capitalistas, revela sua aderência a realidade maior da formação social latino-americana: a dependência 
estrutural da economia e da sociedade face aos centros desenvolvidos do Capitalismo globalizado. O trabalho informal, neste contexto, é o extremo social do processo econômico denominado por Marini de superexploração do trabalho, quando a intensificação do trabalho, o aumento da jornada e enfim, a remuneração da força de trabalho abaixo do seu valor real comprimem os produtores na sua luta para sobreviver.

O declínio da importância dos produtos que se baseiam em diferenciais de custo determinados pelo uso intensivo de mão-de-obra barata apenas aumenta a exclusão social e a informalidade na economia. Os produtos baseados no saber e na tecnologia avançada estão ainda mais concentrados nos setores dinâmicos do Capitalismo. O aumento desta concentração de tecnologia, informação, capital e outros recursos geram renda e riqueza para seus proprietários. O diferencial de saber e tecnologia produz informalidade e exclusão social em todos os níveis, seja pela desigualdade social, resultante da concentração de renda e recursos, que empobrece várias camadas sociais, seja pela incorporação subordinada dos produtores nos micro-negócios e pequenas empresas que desenvolvem atividades econômicas a reboque das empresas dinâmicas, superexplorando o fator trabalho e usando expedientes informais e ilegais como forma de subsistência.

A discussão sobre informalidade diz respeito aos problemas sociais que possuem caráter heterogêneo e mutante. Nessa perspectiva, as teorias sobre a economia ou trabalho informal são tentativas de organizar mentalmente, mas também praticamente, os fenômenos sociais, posicionando-os em relação à ordem social.

Percebe-se que a informalidade está relacionada ao empreendedorismo, à autonomia e à ausência de regulamentações legais; à natureza dual das economias; à marginalidade das ocupações diante dos setores mais dinâmicos da economia; ou ao caráter periférico e dependente das formações sociais capitalistas latinoamericanas. 
Nessa perspectiva, há consenso sobre as características dessas ocupações: precariedade do trabalho e baixa produtividade, quase sem separação entre capital e trabalho, em que a margem de lucro não alcança altas taxas. A economia informal e o trabalho informal podem ser caracterizados como atividades intersticiais transitórias ou fenômenos sociais massivos resultantes da acumulação capitalista em economias dependentes.

O crescimento ou não da informalidade no Brasil é assunto de debate. Existe o questionamento quanto ao crescimento ou não das taxas de formalização no mercado de trabalho. Em muitos casos os critérios de informalidade adotados pelos órgãos responsáveis são diferentes entre si. A taxa de informalidade ou de sub-emprego costuma estar associada à de desemprego aberto ou simplesmente desemprego; os terceirizados e quarteirizados são considerados trabalhadores empregados. Além da polêmica em torno das informações estatísticas, encontramos diferenças nos conceitos adotados pelos próprios pesquisadores em seus estudos. Percebe-se uma constante variação no que diz respeito às definições de trabalho informal; desemprego aberto; desemprego e assalariado sem carteira, entre outras.

Desde a década de 90, as empresas brasileiras passam por um processo de adaptação às novas formas de organização da produção, decorrentes da nova divisão internacional do trabalho, com efeitos também no mercado de trabalho informal. O enfoque das novas formas de organização do trabalho se originou nos países desenvolvidos e sustenta a tese de que tem surgido uma nova divisão do trabalho como resposta à crise mundial, cujas conseqüências principais têm sido a queda da produtividade e a instabilidade da demanda.

Diante da reestruturação do sistema econômico mundial ou da reestruturação produtiva, as empresas têm procurado reduzir os custos fixos, em especial os salários, diante novas formas de organização do trabalho e da gestão de mão-de-obra. A 
introdução de novas tecnologias tem permitido substituir a produção de massa pela produção flexível que favorece a descentralização dos processos.

As redes de pequenas empresas que funcionam como unidades distribuidoras ou processadoras de insumos mantêm relações de subcontratações dinâmicas de diversas formas, como os terceirizados, os quarteirizados, os prestadores de serviços como pessoa jurídica, os autônomos, etc. Destaca-se a dificuldade de se obter informações sobre as condições de trabalho e de saúde desses trabalhadores subcontratados pelos órgãos de fiscalização, na medida em que não possuem vínculo direto com a empresa principal. As empresas prestadoras de serviço muitas vezes se encontram em situação irregular de ordem tributária, de registro na prefeitura, de falta de cumprimento da legislação trabalhista, entre outras irregularidades.

Para ANTUNES ${ }^{135}$, o processo de reestruturação produtiva está ligado a um novo tipo de acumulação de capital denominado de acumulação flexível, cuja maior expressão seria o toyotismo, apontado como substituto do fordismo como forma de organização da produção. Segundo CACCIAMALI ${ }^{136}$, a utilização de empregos flexíveis por parte das empresas em suas estratégias de produtividade possui pelo menos dois atributos: diminui os custos diretos e indiretos do trabalho e permite, com maior velocidade, o ajustamento do emprego em um ambiente caracterizado por mercados mais competitivos, com maior flutuação de demanda. A redução dos custos indiretos concretiza-se com práticas de subcontratação, nas quais a relação de trabalho, que antes era subordinada a estatutos trabalhistas, é transferida para uma relação comercial, sujeita aos estatutos comercial e civil. A autora diferencia a informalidade do fenômeno da pobreza, na medida em que existem trabalhadores formais pobres.

135 ANTUNES, Ricardo(2000). Os Sentidos do Trabalho. São Paulo: Ed. Boitempo.

136 CACCIAMALI, Maria Cristina ( 2002). Princípios e Direitos Fundamentais no Trabalho na América Latina. São Paulo em Perspectiva, vol. 16, n 2, abril jumho, pp. 64 - 75 
Podemos considerar, segundo os autores, que as tendências de subcontratação e de terceirização da mão-de-obra são expressões do processo de informalização da economia, da precarização do trabalho e da falta de proteção legal. Desta maneira, a reestruturação produtiva e a flexibilização do trabalho podem ser vistas como "pano de fundo" em relação ao qual a compreensão do sentido econômico da informalidade deve ser construída. No padrão flexível de trabalho, percebemos o crescimento das práticas de precarização do emprego, deterioração das condições de trabalho, diminuição do salário e aumento do desemprego ${ }^{137}$. A discussão sobre o trabalho flexível torna-se importante na medida em que se reconhece a correlação entre reestruturação produtiva de um lado, e exclusão social, desigualdade e pobreza, de outro.

De acordo com a polêmica sobre a centralidade ou não do trabalho como categoria sociológica, só podemos concordar com a idéia de que cada vez mais estamos sujeitos à intensificação do trabalho, com o prolongamento da jornada de trabalho, com o fim da era do emprego estável e com o crescimento da economia informal. Destacamse os processos de precarização do trabalho com novos padrões tecnológicos e a deterioração do mercado de trabalho em padrões competitivos no comércio global.

Esta realidade atinge o próprio movimento sindical, as estratégias empresariais no que diz respeito à gestão do trabalho, o perfil do mercado de trabalho e a legislação trabalhista. As relações de trabalho no Brasil foram afetadas de maneira negativa com a redução dos direitos sociais e trabalhistas e se percebe o aumento das diversas formas de trabalho flexível e precário.

A desigualdade social é agravada por essas tendências desestruturantes da produção e do mercado de trabalho. A informalização da economia brasileira, isto é, a proliferação dos pequenos negócios e de um processo de “desalariamento" dos 
trabalhadores, de queda da renda das famílias, contribuiu para a deterioração do mercado de trabalho em que os trabalhadores são sub-utilizados e sub-remunerados.

A flexibilização da Consolidação das Leis do Trabalho (CLT) tem se revertido em processos de perdas salariais e sociais, de intensificação das jornadas e dos ritmos de trabalho e de controle disciplinar por meio de ameaças de demissão. Apesar das limitações, a CLT continua sendo a grande referência para as relações de trabalho não cobertas pelos vínculos da formalidade.

Castro e Dedecca ${ }^{138}$ criticam a idéia de que os problemas do emprego e da renda devam ser combatidos com políticas de flexibilização do trabalho junto com a qualificação profissional, ressaltando que a precarização do trabalho, a queda da renda proveniente do trabalho e a deterioração do mercado devem ser enfrentadas sem a redução dos direitos sociais e sem privatizar e individualizar as relações de trabalho. Para os autores, deve-se tentar reconstituir a esfera pública das relações sociais.

Para concluir, concordamos com a visão que vincula o trabalho informal e a economia informal ao funcionamento regular do Capitalismo, cujas condições são agravadas pelas estruturas sociais e econômicas criadas pelo imperialismo econômico e pela dependência estrutural ${ }^{139}$. A economia informal tem a característica de reproduzir antigas formas de trabalho, como trabalho domiciliar; trabalho em cooperativas; trabalho por conta-própria; trabalho autônomo; e trabalho em micro e pequenas empresas. Nesta perspectiva, reproduz para a maioria de seus integrantes relações sociais de trabalho precárias e sub-remuneradas (subemprego).

O crescimento da economia informal se deve à economia capitalista globalizada que, atualmente, está sob o domínio do capital financeiro ${ }^{140}$, gerador de desemprego

138 CASTRO, Nadya e DEDECCA, Cláudio ( 1998). Flexibilidade e Precarização: Tempos mais Duros. In: CASTRO, Nadya e DEDECCA, Claídio (orgs). A Ocupação na América Latina: Tempos mais duros. São Paulo, ALAST, pp. 9-18. 
estrutural e tecnológico. Nesta situação, o trabalho informal - ou as relações informais de trabalho não-registradas oficialmente - possui uma funcionalidade na economia capitalista. Esta funcionalidade é semelhante àquela do trabalho formal, com a vantagem de oferecer baixos custos ao empresário e menor cidadania ao trabalhador.

Concordamos que integram a economia informal os trabalhadores do exército industrial de reserva, isto é, os desempregados que desempenham atividades econômicas de sobrevivência (população flutuante/desemprego oculto); os trabalhadores autônomos (população latente/trabalhadores por conta-própria); e a indústria em domicilio ou trabalho em domicílio, o artesanato e os trabalhadores domésticos (população estagnada ou pauperizada). Também integram a economia informal os trabalhadores subempregados (lumpemproletariado). Destacamos que estes trabalhadores não devem ser considerados como marginais no sentido de independentes do sistema econômico capitalista. Além disso, contamos com novas formas de emprego de mão-de-obra, tais como a subcontratação e a terceirização e relacionamos estas ocupações diretamente ao processo capitalista de produção.

Acreditamos que o processo de desenvolvimento capitalista requer a existência de economias ou camadas sociais não-capitalistas ou pré-capitalistas para possibilitar sua expansão, seja como mercados para seus produtos (mercados externos), seja como fontes de força de trabalho barata. À medida que o crescimento da economia capitalista depende da subordinação de mercados externos à sua lógica de funcionamento, o setor informal da economia está sujeito aos setores mais dinâmicos do sistema capitalista.

Neste sentido TAVARES ${ }^{141}$ afirma que a subordinação do trabalho informal à lógica do capital explica a expansão das atividades informais na produção capitalista. Em outras palavras, a economia de sobrevivência de vastas camadas sociais está 
subjugada pelo sistema hegemônico capitalista e sua lógica de superexploração do trabalho. Nesta perspectiva, podemos dizer que a economia informal não é nada mais do que a expressão do processo de subordinação de mercados e camadas não-capitalistas ao sistema hegemônico capitalista que, assim, garante o seu crescimento.

O processo de flexibilização do direito ao trabalho, de desregulamentação da economia e do mercado de trabalho, bem como os mecanismos do Capital para se reestruturar, tais como a terceirização, a subcontratação e a contratação por serviços temporários, faz parte do processo de informalização da economia. Podemos considerar estes vínculos atípicos como elos de ligação entre a economia informal e as empresas capitalistas, que apenas tendem a generalizar as relações de trabalho desprotegidas legalmente. Dessa maneira, o trabalho informal constitui uma inserção perversa do trabalhador no mercado de trabalho. Este fato diz respeito a uma expansão das atividades capitalistas à margem da legislação e do Estado.

O vínculo existente entre as transformações das relações de trabalho, a questão do desemprego e subemprego e a informalidade demonstra a necessidade de uma atuação decisiva do Estado e da sociedade para reconstruir as relações sociais desestruturadas pela exclusão social e, principalmente, estender os direitos sociais a todos os trabalhadores, independentemente do status da sua relação de trabalho, visando a uma cidadania plena e não-regulada. Da mesma forma, faz-se necessário o combate à pobreza e à desigualdade social e a defesa da distribuição de renda e riqueza entre os estratos sociais. Esta questão torna-se fundamental no sentido de que tanto a pobreza, quanto a desigualdade social estão associadas com a informalidade, principalmente nos países em desenvolvimento como, por exemplo, o Brasil e os países latinoamericanos. 


\section{CAPÍTULO 2: CAPITALISMO, DESIGUALDADE E DESENVOLVIMENTO}

As sociedades atuais se confrontam com o desafio da globalização ou mundialização da economia, com a reestruturação produtiva e a existência forçada de um mercado autorregulado. A competitividade e a concorrência aguerridas estão presentes no seio de cada Estado e entre Estados. Nesse contexto, há preocupação em relação às defesas contra a sociedade de mercado e a favor da existência de proteções e direitos sociais, a fim de enfrentar os riscos de desagregação da sociedade. A questão social do momento diz respeito ao papel do Estado capitalista diante da situação do desemprego; da flexibilização da contratação; do trabalho informal; do trabalho com vínculos atípicos, em relação ao trabalho assalariado com carteira e estável; do trabalho precário; da desigualdade socioeconômica; da pobreza; e da exclusão e injustiça social.

Segundo CASTEL, a questão social é como uma

aporia fundamental, uma dificuldade central, a partir da qual uma sociedade se interrogava sobre sua coesão e tentava conjurar os riscos de sua fratura (...) Era um desafio que questionava a capacidade de uma sociedade de existir como um todo, como um conjunto ligado por relações de interdependência.

Nessa perspectiva, o autor comenta que a

"nova questão social, hoje, era o questionamento da função integradora do trabalho na sociedade (...), da desmontagem do sistema de proteções e garantias que eram vinculadas ao emprego e uma desestabilização, primeiramente da ordem do trabalho, que repercutiu como uma espécie de choque em 
diferentes setores da vida social, para além do mundo do trabalho propriamente dito" $" 142$.

O debate em torno da existência de uma "nova questão social" surgiu na Europa e nos Estados Unidos no final da década de 1970. Isso ocorreu a partir do momento em que problemas, como o desemprego, a pobreza e a exclusão, passaram a ser percebidos como estados permanentes, não mais conjunturais e residuais, como se acreditava no período de "Trinta Gloriosos Anos" após a Segunda Guerra Mundial. A crise do Estado de Bem Estar Social - ou Welfare State -, e suas consequências sobre a sociedade capitalista de mercado provocou a discussão por parte de vários teóricos sobre o papel do Estado, os direitos sociais e as condições de cidadania num contexto de intensas transformações econômicas.

Nesse capítulo discutirei, em primeiro lugar, a questão social e o papel do Estado segundo os seguintes autores: Robert Castel; Pierre Rosanvallon; e Amartya Sen. A escolha desses teóricos deve-se a sua importância e relevância no debate proposto e às diferentes abordagens que fazem do problema. CASTEL ressaltou a importância do papel do "Estado Protetor" na implantação de políticas universais e defendeu a criação de uma sociedade salarial como meio de gerenciar os riscos de desagregação social.

Por outro lado, ROSANVALLON defendeu a existência de um "Estado Mínimo" para solucionar os problemas relacionados ao desemprego, pobreza e desigualdade. Nesse caso, seria necessário privilegiar as redes de solidariedade na sociedade e as iniciativas privadas ao invés da ação assistencial do Estado. ROSANVALLON defendeu a privatização. O autor defendeu a privatização da economia e da assistência social, além da existência de um mercado autorregulado, de acordo com a política neoliberal. Já SEN relacionou os padrões de desenvolvimento

142 CASTEL, R. (2004). As transformações da questão social. In: CASTEL, Robert et alli (orgs). Desigualdade e a questão social. São Paulo: EDUC, $2^{\circ}$ edição, versão ampliada, pp. 239-240. 
capitalista com as oportunidades sociais. O autor destacou a importância das oportunidades sociais, como assistência à educação e saúde, entre outras, e da existência de um "Estado Social" que tem por prioridade o bem-estar coletivo ao invés do individual.

Em segundo lugar, será abordada a questão das desigualdades socioeconômicas, dos padrões de desenvolvimento capitalista em relação às oportunidades sociais existentes no leste asiático e na América Latina. Para a elaboração desse item, foram utilizados textos de HIRANO e ESTENSSORO"143. Os autores referiram que "a estrutura de poder mundial fundou-se em modos de desenvolvimento diferenciados nas diversas regiões do planeta, que se reportaram a diversos padrões de acumulação e inserção internacional das economias nacionais, empiricamente verificáveis em cada região geoeconômica". Nessa perspectiva, existiu o pressuposto de que "o modo de desenvolvimento anglo-americano produzia estruturalmente mais pobreza e desigualdade social do que o modo de desenvolvimento japonês-asiático".

Em terceiro lugar procurarei analisar os direitos sociais e a cidadania dos trabalhadores no contexto da realidade brasileira. A construção da cidadania no Brasil ocorreu de maneira singular e distinta dos países europeus. Diante da política neoliberal, a questão que se apresenta hoje está ligada, principalmente, à legitimidade e eficácia dos direitos. Com as grandes transformações econômicas, é necessário repensar políticas e conceitos que possam abranger as relações entre trabalho, direito e cidadania. Na leitura empreendida, são utilizados como referências alguns autores nacionais, como: Wanderley Guilherme dos Santos; Vera da Silva Telles; Maria Célia Paoli; José de Souza Martins; e Sedi Hirano, entre outros.

143 HIRANO, S. \& ESTENSSORO, L. (2006). Padrões de Desenvolvimento e de Oportunidade Social na América Latina e no Leste Asiático. Cadernos PROLAM/USP, Ano 5, vol. 2, p. 105. 


\subsection{Estado e questão social}

CASTEL $^{144}$ discutiu a construção de uma sociedade salarial e os riscos de desagregação com base na realidade européia, principalmente em relação à França. Apesar das diferenças, as proposições do autor trouxeram contribuições importantes para a discussão da realidade brasileira, principalmente por abarcar questões que se desenrolaram também em nosso cotidiano. A questão principal diz respeito à produção de vulnerabilidades sociais devido à perda da condição de "trabalhador estável" ("zona de integração"), para uma parcela da sociedade que se situa em uma zona de precariedade $^{145}$ ("zona de vulnerabilidade"; "zona de assistência"; e "zona de desfiliação"). Tal zona abrange as pessoas desempregadas, com trabalhos precários e com vínculos de solidariedades e proximidades frágeis, na situação de pobreza.

O autor realizou análise das transformações históricas da sociedade capitalista e confirmou que a questão social, assim nomeada pela primeira vez em 1830, foi suscitada pela constatação de um distanciamento entre o crescimento econômico e o aumento da pobreza, por um lado; e por outro lado entre uma ordem jurídico-política que reconhecia o direito dos cidadãos e uma ordem econômica que os negava. A questão foi levantada após a Revolução Industrial, que provocou grandes transformações econômicas, políticas e sociais na Europa do século XVIII, afetando seriamente a vida das populações ${ }^{146}$.

\footnotetext{
144 CASTEL, Robert (1998). As metamorfoses da questão social: uma crônica do salário. $\quad$ Petrópolis, editora Vozes, p. 30. 145 CASTEL (1998) levantou quatro tipos de "zonas" nas quais os indivíduos podem estar distribuídos. A primeira corresponde à "integração". Nesta, o agente social possui as garantias de um trabalho permanente e ainda está inserido em relações sociais sólidas. Na segunda, a zona da "vulnerabilidade”, o indivíduo atravessa uma situação na qual é ameaçado pela precariedade do trabalho e tinha tem seus laços sociais enfraquecidos. Na terceira, que seria a "zona da assistência", é a esfera pública que evita o desligamento do indivíduo atingido pela precarização e pelo enfraquecimento dos laços familiares. Por último, a "zona de desfiliação" é ocupada por aqueles que não somente estão em situação de desemprego, mas que também perderam as relações que haviam sido produzidas no mundo do trabalho, no bairro, na vizinhança próxima, etc. Vide pp. 549-550. 146 CASTEL, Robert (1998), p. 30
} 
A questão social é caracterizada por "uma inquietação quanto à capacidade de manter a coesão de uma sociedade. A ameaça de ruptura é apresentada por grupos cuja existência abala a coesão do conjunto" ${ }^{\text {"147 }}$. Explicitando a composição de tais grupos, o autor esclarece que as populações que dependem de intervenções sociais são diferenciadas pelo critério de serem ou não capazes de trabalhar, sendo tratadas de forma distinta em função deste critério. A análise parte da identificação no longo prazo de uma correlação profunda entre o lugar ocupado pelo indivíduo na divisão social do trabalho e sua participação nas redes de sociabilidade e nos sistemas de proteção.

Na sociedade pré-industrial, a assistência era dada a uma parcela da população isenta de trabalhar. Esse grupo era reconhecido por um núcleo de situações de dependência reconhecidas, que os incapacitava de se enquadrar à ordem do trabalho e que poderiam acarretar em situações familiares desastrosas: deficiências físicas e psíquicas manifestas, idade e doenças. Desde o século XIV, havia intervenções públicas voltadas à prestação de assistência aos indigentes e à manutenção da ordem pública. Castel chamou de social-assistencial o tipo de intervenção pública através do qual o Estado age como fiador da organização social, do trabalho e regulador da mobilidade laboral. Os destinatários dessa assistência são diferenciados entre si à medida que estão ou não em condições de trabalhar e, dependendo do caso, recebem tratamentos distintos.

Na fase do capitalismo industrial, a diferença da questão social em relação ao período anterior diz respeito ao surgimento de novos atores e novos conflitos. A questão social torna-se a questão "de qual lugar os contingentes mais dessocializados podem ocupar na sociedade industrial", colocando com muita propriedade que "a questão social se põe explicitamente às margens da sociedade, mas 'questiona' o conjunto da 
sociedade"148. Nessa perspectiva, a resposta "será o conjunto dos dispositivos montados para promover sua integração"

Dessa maneira, o lugar do social é colocado entre a organização política e o sistema econômico, deixando clara a necessidade de construir sistemas de regulação não-mercantil, com o objetivo de tentar preencher esse espaço. Então, surge a questão do papel que o Estado era chamado a desempenhar na sociedade francesa. CASTEL chama de "Estado social" a intervenção estatal na interseção do mercado e do trabalho. No pós-guerra, a articulação do econômico e do social parece ter encontrado uma solução satisfatória o bastante para que fosse considerada definitiva. $\mathrm{O}$ modo de gestão política associou as sociedades privada e social, o desenvolvimento econômico e a conquista dos direitos sociais, o mercado e o Estado.

A crise econômica do início da década de 1970 afetou em primeiro lugar o emprego. Sua principal manifestação foi o surgimento do desemprego em massa e, não menos importante, da precarização do trabalho. Após décadas de quase pleno-emprego, com a generalização da proteção que caracterizou a sociedade salarial, surgiram novamente os "inúteis para o mundo", ou seja, pessoas e grupos que se tornaram supranumerários, "inempregáveis", desempregados ou empregados de um modo precário e intermitente ${ }^{150}$, diante das alterações das competências econômicas e sociais.

Os indivíduos que não possuíam as qualificações exigidas pelo mercado eram jogados para fora dos "circuitos de trocas produtivas" e se tornavam inúteis na perspectiva de uma sociedade que se articulava pela interdependência funcional entre seus membros. Por isso, havia uma "crise da identidade pelo trabalho". Os "inúteis pra o mundo" constituíam um contingente heterogêneo, sem força de pressão ou potencial de luta, que não existia socialmente, à medida que tais pessoas não eram consideradas 
produtivas. Mas apesar de "não existirem socialmente" e de "serem inúteis para a sociedade", elas estavam bem presentes e consistiam num problema social, pois eram numerosos demais ${ }^{151}$.

A empresa capitalista se transformou numa imensa produtora de trabalhadores vulneráveis (desqualificou os trabalhadores que não mais eram aptos às exigências da produção, demandou qualificações que poucos possuíam e manteve a todos suspensos pelo fio do fluxo de demanda que advém do mercado). Temos aí a máxima mercantilização da força de trabalho. A precarização não atingiu somente os bem capacitados, mas também aqueles que possuíam qualificações e sempre estiveram estabilizados. Neste sentido, a "precarização do trabalho é um processo central, comandado pelas novas exigências tecnológico-econômicas da evolução do capitalismo moderno" $" 152$.

$\mathrm{Na}$ teoria exposta, existe a preocupação de dimensionar a presença cada vez mais insistente de indivíduos colocados em situação de flutuação na estrutura social e que povoava povoam seus interstícios sem encontrar aí um lugar designado. Trajetórias incertas de desempregados por longos períodos, moradores de subúrbios pobres, beneficiários de renda mínima de inserção, vítimas de readaptações industriais, jovens à procura de emprego, que passam de estágio em estágio, de pequeno trabalho à ocupação provisória, entre outros. CASTEL realiza as seguintes indagações: quem são eles, de onde vêm, como chegaram ao ponto em que estão, o que vão se tornar? ${ }^{153} \mathrm{O}$ autor indaga o futuro imprevisível dessas pessoas, que poderiam ser chamadas de "sobrantes", “desfiliadas" pessoas que não têm lugar na sociedade e não são ${ }^{154}$.

151 Idem, p. 33

152 CASTEL, R. (1998), p. 526

153 CASTEL, R. (1998), p. 23.

154 CASTEL, R. (2004). As transformações da questão social. In: CASTEL, Robert et alli (orgs). Desigualdade e a questão social. São Paulo: EDUC, $2^{\circ}$ edição, versão ampliada, p. 254. 
$\mathrm{Na}$ vulnerabilidade dos indivíduos no mercado de trabalho está dada a possibilidade para o que CASTEL chama de "desfiliação" - que equivale à condição caracterizada pela "ausência de inscrição do sujeito em estruturas portadoras de sentido" "155. Este indivíduo "desfiliado" não é um excluído, pois não vive uma situação de "ausência completa de vínculos"; não está fora da sociedade, mas distante de seu centro de coesão. O conceito de exclusão foi historicamente utilizado para designar ou aqueles que eram repelidos e retirados do convívio social, ou aqueles que não possuíam direitos frente a outros que os possuíam.

$\mathrm{Na}$ idéia de exclusão, foram encontradas situações como o confinamento em guetos, o banimento, a expulsão, a discriminação jurídica e a restrição de acesso, entre outras. Segundo CASTEL, não são essas as situações que se colocam no fim do século $\mathrm{XX}$, mas sim a fragilização total das ligações socioeconômicas de um número muito grande de indivíduos em relação à sociedade. Trata-se de uma desfiliação destes indivíduos de processos econômicos de produção, e consequentemente de consumo, derivada de uma precarização das relações de trabalho e de uma consequente vulnerabilização da condição salarial e dos vínculos sociais.

Não há uma divisão nítida entre vulneráveis e desfiliados. O trabalhador vulnerável consiste naquele empregado que pode ser demitido a partir de qualquer necessidade da empresa, tornando-se, em consequência, um desfiliado caso esta ruptura do vínculo com o mercado de trabalho seja duradoura o suficiente para causar impacto sobre as relações sociais mais amplas que cercam o trabalhador e significam sua outra ponta de integração e coesão social (laços familiares, de parentesco, redes de amizade, etc.). Para CASTEL, os indivíduos têm dois pontos de conexão que funcionariam como motores de coesão com sociedade, um de fundo econômico e outro, interacional.

155 CASTEL, R. (1998), p. 536. 
Neste ponto, é possível observar que a metamorfose da questão social ou a nova questão social é o questionamento da função integradora do trabalho na sociedade. Se inicialmente a questão era como fazer um ator social subordinado, dependente, tornar-se um sujeito social através do trabalho assalariado, estável, com proteções e garantias vinculadas ao emprego, hoje em dia a questão é amenizar a presença do Estado de Bem Estar Social, torná-la discreta até apagá-la na medida em que diversas pessoas se tornaram "inúteis e "inempregáveis". As políticas de inserção, qualificação profissional e renda mínima são medidas importantes para amenizar os problemas, mas não os resolvem totalmente.

CASTEL, afirma se tratar de uma nova problemática, mas não de outra problematização. A situação de remercantilização plena da força de trabalho, que passou a ser mais uma vez (como nos tempos iniciais da Revolução Industrial) submetida aos critérios únicos do mercado, consistiu no elemento fundamental que colocou as bases para a precariedade do trabalho ${ }^{156}$ e para a generalização do desemprego. Como afirmou o autor de forma enfática: "De agora em diante, para muitos, o futuro era marcado pelo selo do aleatório" ${ }^{157}$. O foco central é o risco de ruptura da solidariedade coletiva, anomia decorrente da perda da coesão e integração social, segundo a teoria de DURKHEIM ${ }^{158}$.

Sob a ótica de CASTEL, a sociedade atual se encontra numa bifurcação: aceitar uma sociedade inteiramente submetida às exigências do mercado, ou construir uma figura do Estado social capaz de atender ao novo desafio. A aceitação da primeira opção representaria o desmoronamento da sociedade salarial. Já a segunda opção representaria uma redefinição de um pacto de solidariedade e cidadania. Percebe-se que é necessário

156 A precarização no trabalho consiste em uma série de eventos, como contratos de trabalho por tempo determinado, trabalho de tempo parcial, trabalho temporário e outras formas de emprego que colocaram em xeque o contrato de trabalho por tempo indeterminado, uma das bases de sustentação da sociedade salarial durante décadas. 157 CASTEL, R. (1998), p. 21. 
o "tratamento social do desemprego e a inserção da população já invalidada pela situação econômica social"159 . Nessa perspectiva, o papel do Estado na regulação do mercado e os sistemas de proteção ligados ao trabalho se tornam pontos centrais da questão social.

Em contraposição às idéias de CASTEL, comento as proposições de alguns autores que defendem a idéia da presença de um "Estado Mínimo" para solucionar os problemas relacionados à "nova questão social". ROSANVALLON refere que a crise do "Estado-Providência", além de ser de natureza econômica, agravada pelo desemprego em massa, pelas despesas sociais e pela má gestão da seguridade social está relacionada aos aspectos social e político. A crise ideológica que acompanhou a "nova questão social" possui dois problemas principais: a desagregação dos princípios de organização de solidariedade; e o fracasso de concepção tradicional dos direitos sociais, que tinha como proposta gerar um contexto satisfatório para considerar a situação dos excluídos ${ }^{160}$. Segundo esse autor, o maior desafio para superar a crise é a necessidade de buscar um "novo contrato social entre indivíduo, grupos e classes"161.

Os antigos mecanismos produtores de solidariedade baseavam-se no sistema de seguro social, sendo que a solidariedade se fundamentava na mutualização crescente dos riscos sociais, de tal forma que o "Estado-Providência" se identificava com uma espécie de "sociedade securitária", "Estado-Providência Compensatório", ou "Estado-protetor". Nesse período, havia um sistema único de proteção social de natureza universal e mecanismos de assistência social adequados àqueles segmentos da população em estado de risco. ROSANVALLON defende que o "Estado-Providência" causou um equívoco ao tentar homogeneizar os tratamentos.

159 CASTEL, R. (2004). As armadilhas da exclusão. In: CASTEL, Robert et alli (orgs). Desigualdade e a questão social. São Paulo: EDUC, $2^{\circ}$ edição, versão ampliada, p. 31

160 ROSANVALLON, Pierre (1998). A nova questão social: repensando o Estado-Providência. Brasília: Instituto Teotônio Vilela, p. 25. 161 ROSANVALLON, Pierre (1997). A crise do Estado-Providência. Goiânia: UFG, p.8. 
Em um contexto de desemprego de massa e de aumento de exclusão, percebe-se a degradação da visão securitária da solidariedade. ROSANVALLON cria então o conceito de "Estado-Providência passivo", caracterizado pela incapacidade de gerenciar riscos de longa duração ${ }^{162}$. Dessa maneira, o autor propõe um "Estado-Providência ativo", que busca o enriquecimento da noção de direito social em um novo caminho de inserção do indivíduo na sociedade, qual seja, por meio das redes de solidariedade. Tal proposta descarta a ação indenizatória do Estado como único caminho. Sendo assim, além dos tradicionais procedimentos, o "Estado-Providência" deve personalizar seus meios de atuação, para adaptar-se ao caráter específico das situações. Os casos de desemprego, pobreza e exclusão devem ser tratados como situações particulares, de maneira individualizada, e receber ajudas diferenciadas.

Para o autor, a crise filosófica do "Estado-Providência" leva a "retomar, em suas raízes, a questão dos direitos como ela foi formulada, desde o século XVII, pelo individualismo liberal", na tentativa de "ultrapassar velhas oposições entre direitos formais e direitos reais, direitos sociais e políticos". Além disso, conduz à reconsideração das "expressões do contrato social, a reformular a definição do que era justo e equitativo e a reinventar as formas da solidariedade social” ${ }^{163}$. Nesse contexto, ROSANVALLON refere que as políticas universais do Estado, defendidas por CASTEL, estão ultrapassadas. Dessa maneira, propõe que o Estado assuma a forma de um Estado-Providência ativo, produtor de "civismo": “ já que nem o mercado (...), nem o Estado (...) poderiam criar atividades sociais que ultrapassavam o Estado-Providência passivo, a noção do "terceiro setor" surgiu necessariamente na ordem do dia"164.

O autor critica sistema de seguridade social francês, universal, único, mantido por diversos tipos de organizações e de caráter contributivo e assistencial. Nesse

162 ROSANVALLON, Pierre (1998), p. 26.

163 Idem, p. 26.

164 Idem, p. 137. 
contexto, a crise do Estado-Providência tem uma causa econômica. O modelo keynesiano é determinante para a crise do modelo de Estado-Providência estatal, pois o keynesianismo se mostra incapaz de superar as crises econômicas da atualidade $^{165}$. ROSANVALLON defende a instituição de um imposto de caráter geral, a extensão da previdência privada e critica a estatização da economia francesa ${ }^{166}$. A previdência oficial ficaria responsável apenas pelos casos de indigência. Com essas medidas, acredita ser possível a reconstituição dos direitos e da solidariedade social.

A proposta de ROSANVALLON para enfrentar a "nova questão social" ganha importância ao ser confrontada com a diminuição do Estado, frente a contextos em que ações do Estado passam ao setor privado em nome da solidariedade - por exemplo, a partir das organizações não governamentais (ONGs). No Brasil, tal movimento se reflete, para citar um caso, no Programa de Economia Solidária proposta pelo governo para atender a população carente, contando com uma contribuição financeira significativa do setor privado. Por trás de todo esse processo de mudança no enfrentamento "questão social", o que surge com a diminuição do Estado é uma mudança no âmbito das relações entre as classes e o Estado - transformação que se configura pelo atual contexto histórico-social da crise dos padrões de regulação sócioestatal e pela difusão do neoliberalismo, com sua retórica em defesa do "Estado Mínimo".

A estratégia de ROSANVALLON parece articular-se coerentemente com a busca de livrar o Estado da responsabilidade pela garantia dos direitos de cidadania. Nessa perspectiva, se encaixavam os processos de descentralização, terceirização e privatização, elementos presentes na reforma do Estado que vem sendo implementada no Brasil desde finais dos anos 80 .

165 ROSANVALLON, Pierre (1997), p. 42. 
A proposição do autor, de reinvenção do Estado com vistas a manter a coesão social, foi alvo de críticas. Há dúvidas quanto à capacidade do Estado-Providência ativo de exercer justiça através do conhecimento das diferenças entre os homens, dando-lhes tratamento diferenciado. Na verdade, o que o autor defende é que o problema das desigualdades, da desigual distribuição da riqueza acumulada pelo sistema produtivo, cuja origem é a exploração dos trabalhadores e a concentração dos meios de produção nas mãos dos capitalistas, seja resolvido pela lógica do mercado e sem a interferência do Estado.

Outro autor que critica a ação demasiado assistencialista do Estado é AMARTYA SEN. O economista indiano prioriza o par desenvolvimento e liberdade como solução das questões sociais - da pobreza, da fome, da desigualdade e do desemprego, entre outros. Nessa perspectiva, o desenvolvimento é um processo intimamente atrelado à expansão e à garantia de liberdade para todos os indivíduos, com vistas a propiciar melhores condições para a expansão das liberdades individuais. A partir do desenvolvimento, segundo AMARTYA SEN, "se renovavam as principais fontes de privações de liberdade: pobreza e tirania, negligência dos serviços públicos e intolerância ou interferência excessiva de Estados repressivos"167. Sua teoria procura ressaltar a dimensão ético-política dos problemas econômicos e superar a dicotomia entre o modelo socialista e o liberal na maneira de enfrentar os problemas sociais.

A constatação de que índices de "crescimento", como aumento do PNB, por exemplo, nem sempre significam melhorias nas condições de vida dos indivíduos é uma de suas principais premissas. Para SEN, o desenvolvimento, além de proporcionar aumentos na produção e renda, tem de remover os principais obstáculos à privação de liberdade, principalmente a fome; as restrições do acesso à saúde, à educação e ao 
trabalho; a falta de saneamento básico, de moradias e vestimentas adequadas. Segundo o autor, uma das piores privações é a restrição dos indivíduos ao livre mercado - esta a questão mais polêmica em seu trabalho. A possibilidade dos indivíduos buscarem seus próprios meios de subsistência no mercado é considerada por ele como essencial para garantir a autonomia - e consequentemente, a liberdade - dos cidadãos. Nessa perspectiva, qualquer política que, de alguma maneira, restrinja ou reprima o livre acesso às mercadorias em "mercado livre" deve ser desprezada.

Para SEN, a incapacidade de proporcionar aos indivíduos condições para que eles próprios busquem no mercado produtos que satisfaçam suas necessidades é a mais perversa privação de liberdade que existe nos países ocidentais. Porém, é inegável que essa privação está intimamente relacionada à ineficiência dos mecanismos econômicos de proporcionar trabalho digno a todos os indivíduos. O autor condena a escravidão ou o trabalho "adscrítico" - quando existe algum tipo de coação para que o indivíduo venda sua força de trabalho a um determinado empregador ${ }^{168}$-, apoiando-se na teoria de KARL MARX, que vê "a emergência de liberdade de emprego como um progresso importantíssimo"169.

Nessa perspectiva, a liberdade de escolher onde, como, quando e para quem trabalhar faz parte das proposições de AMARTYA SEN para garantir a condição de cidadão livre. Além disso, a escravidão e as regulamentações que negam a liberdade do mercado de trabalho são privações que condenam o processo de desenvolvimento de qualquer nação. Para o autor, a escravidão é uma privação que vai muito além da simples falta de salário. A idéia nos remete à proposta do fim da centralidade do trabalho como elemento determinante da dinâmica societária. A emancipação, através da organização dos trabalhadores, pode ser questionada devido à reestruturação 
produtiva, o desemprego em massa, o aumento do trabalho precário e informal. Por outro lado, podemos considerar que a questão desemprego e da precarização das relações de trabalho continua presente mais do nunca como um dos principais problemas do contexto atual. A desregulamentação das formas de trabalho acaba afetando sociabilidades, identidades, modos de existência e formas de representação.

A pobreza, para AMARTYA SEN, não se define apenas pela falta ou carência de rendimentos dos indivíduos, mas sim pela privação de suas potencialidades. As privações dependem de vários fatores, como idade, papéis sociais, gênero, localização da moradia, condições epidemiológicas, etc. Sendo assim, nem sempre indivíduos que habitam em países ricos e possuem rendimentos maiores que os habitantes de países pobres possuem mais liberdade, na medida em que "ser relativamente pobre em um país rico pode ser uma grande desvantagem em capacidade, mesmo quando a renda absoluta da pessoa era mais elevada pelos padrões mundiais" ${ }^{170}$. Portanto, percebeu-se que em países ou regiões onde prevalece a riqueza, é necessário ter rendimentos maiores para exercer a condição de "cidadão livre".

A questão da democracia é um dos pontos principais na análise de SEN sobre o desenvolvimento. Para o autor a democracia tornou-se o principal instrumento que os "agentes"171 das regiões possuem para evitar fomes e desastres coletivos. Segundo suas próprias palavras, “....certamente é verdade que nunca houve uma fome coletiva em uma democracia multipartidária efetiva" ${ }^{\prime 72}$. Sendo assim, exercer o ato de votar, criticar e protestar é acima de tudo estar provido de condições de tomar decisões em prol do bem de todos - o que evitaria a submissão aos desígnios de governos autoritários, mais

\footnotetext{
170 P. 111

171 Para Sen, o desenvolvimento só é possível através da atuação de indivíduos agentes livres de privações básicas que lhes tolhe as capacidades de encontrar, no mercado, também livre, as oportunidades para levarem a vida que lhes convém. 172 P. 208
} 
comprometidos em cumprir metas orçamentárias do que com as necessidades reais da grande maioria dos indivíduos.

Exercer a democracia participativa não só evitaria que nações e/ou regiões passassem por situações caóticas - como a fome e epidemias coletivas -, mas também garantiria um futuro consolidado pela participação e os anseios da sociedade. A participação efetiva de cada cidadão faria com que os governos fossem pressionados pelos movimentos populares. Nessa perspectiva, os governantes teriam que assumir compromissos de acordo com as reivindicações da maioria, e não apenas com as classes privilegiadas. Os conflitos gerados pela oposição serviriam à reflexão e como motivação de mudanças estratégicas nas políticas públicas. A democracia ocorreria pela abertura e o diálogo entre agentes sociais, que deveriam ter condições de participação efetiva dentro do processo de decisões.

SEN destaca a importância das decisões individuais e da autonomia de cada um. O autor pontua que não se deve confundir autonomia com "descomprometimento" social. Nesse sentido, todos devem ter responsabilidades para com as injustiças e misérias da humanidade. Não se pode fugir da tarefa de agir em favor dos indivíduos desfavorecidos. SEN ressalta que independentemente de interesses políticos ou religiosos, devemos como seres humanos competentes e "racionais" usar nossa autonomia individual em busca de melhores condições de vida para todos. A falta de oportunidades que afeta muitos indivíduos em várias partes do mundo deve comprometer seu futuro como cidadãos. Esse fato se contrapõe à alegação de que cada um é responsável por seu próprio destino. Na verdade, o autor critica o Estado liberal, pela falta de políticas públicas para a população que vive na miséria e na pobreza.

Para AMARTYA SEN, existe uma diferença entre o Estado que se tornou demasiado assistencialista e o comprometimento social com a liberdade de cada 
indivíduo, que cabe não apenas ao Estado, mas a todos os cidadãos. A partir do "agente social", viria a transformação da sociedade. Ao cidadão adulto, responsável pelo seu próprio bem estar e pelo das pessoas que o cercam cabem as decisões das estratégias de desenvolvimento para o lugar onde ele vive. Para isso, é necessário que o Estado propicie ações efetivas e políticas públicas de formação dos agentes para a participação política e a mobilização em torno dos processos de tomada de decisões. É preciso encontrar mecanismos motivadores para que os indivíduos se sintam comprometidos com a comunidade à sua volta.

SEN acredita nas possibilidades de mudança, embora não apóie as prescrições tradicionais dos economistas, nem as propostas revolucionárias do socialismo. Assim, o crescimento econômico não pode ser considerado um fim em si mesmo; quanto às propostas revolucionárias, consideradas autoritárias, eles as critica ao considerar as liberdades democráticas um meio e, principalmente, o objetivo final do desenvolvimento. Para o autor, a diminuição das desigualdades e o desenvolvimento só podem ocorrer através da liberdade. A liberdade substantiva, liberdade de participação política, oportunidade de receber educação, assistência de saúde, por exemplo, estão entre os componentes constitutivos do desenvolvimento.

As idéias de SEN servem como base teórico-metodológica para políticas de desenvolvimento baseadas na participação social e no fortalecimento da cidadania. Suas propostas não resolvem alguns dos grandes problemas que os países em desenvolvimento, ou pobres, enfrentam. Por outro lado, tais concepções estão afinadas com os princípios de democracia participativa, direitos humanos e liberdades fundamentais. O autor enfatiza a importância da diversidade humana e da existência de uma ética global. 
AMARTYA SEN, destaca a importância do elemento social, do indivíduo, no conceito de desenvolvimento. $\mathrm{O}$ crescimento econômico, neste caso, não está descolado das liberdades individuais. A reflexão realizada por AMARTYA SEN deixa algumas indagações, como por exemplo, sobre a dificuldade de identificar estratégias para alcançar tanto o desenvolvimento, como a liberdade num contexto de tamanha desigualdade, existente entre a maioria dos povos, como por exemplo, o brasileiro. Outra dúvida em relação a AMARTYA SEN diz respeito à maneira de fazer com que políticos tanto de países desenvolvidos, como de países pobres se comprometam não só com as camadas mais privilegiadas da sociedade, mas também com os indivíduos desfavorecidos. Uma terceira questão é sobre como nações pobres poderiam canalizar seus investimentos não só para pagamentos de juros a órgãos internacionais, mas para investimentos sociais, sem que isso causasse rupturas no sistema econômico vigente.

Além disso, resta dúvida sobre os caminhos que levam ao desenvolvimento e à liberdade em sociedades em que o consumo faz parte da experiência de vida dos indivíduos. Sendo assim, de que maneira se pode convencer os indivíduos que possuem riqueza exorbitante a aceitar abrir mão de pelo menos uma parte de seus recursos em favor dos pobres e miseráveis. Apesar de importante a idéia de SEN, de eliminar privações individuais, isto não resolve o problema de inserção do indivíduo num mundo regido pela acumulação de capital, muito distante do mundo imaginado por Smith de indivíduos que produzem e trocam seus trabalhos privados no mercado livre. 


\subsection{Desigualdades e desenvolvimento no capitalismo}

O modo de desenvolvimento capitalista dependente latinoamericano produziu estruturalmente mais pobreza e desigualdade social do que o modo de desenvolvimento em países do Leste Asiático. HIRANO \& ESTENSSORO ressaltam que, por exemplo, no modo de desenvolvimento japonês-asiático, "o mercado era metodicamente orientado aos interesses sociais por um Estado desenvolvimentista". Sendo assim, "esse mercado era utilizado para alcançar objetivos coletivos". Constituiu-se então "um capitalismo regulado, onde o Estado tinha uma presença forte como planejador econômico"173. Trata-se de um "capitalismo social", ou de uma "economia mista" enquanto padrão de acumulação, no qual o mercado é regulado em conformidade com as aspirações dos grupos que compõem a sociedade. Dessa maneira, a ênfase recai sobre o grupo e não sobre o indivíduo, o que privilegia os laços de solidariedade comunitária $^{174}$.

Do ponto de vista ocidental, segundo HIRANO, o modelo japonês-asiático seria ligeiramente "autoritário e conservador", com uma "forte marca econômica nacionalista", em processo crescente de "despolitização do movimento sindical e operário". Por outro lado, o autor ressaltou que esse era um capitalismo que "se fez e se faz capitalista a partir de forte presença do Estado como planejador econômico, almejando metas econômicas que reduzem as desigualdades sociais e a pobreza". Por isso mesmo, pode ser enquadrado em um modelo de "capitalismo social", ou de uma

173 HIRANO, S. \& ESTENSSORO, L. (2006). Padrões de Desenvolvimento e de Oportunidade Social na América Latina e no Leste Asiático. Cadernos PROLAM/USP, Ano 5, vol. 2, p. 106.

174 HIRANO, S. (2004). Capitalismos Mundiais, Desigualdade Social e a América Latina. China em Estudo, nº 6, (Publicação do Departamento de Letras Orientais da Faculdade de Filosofia, Letras e Ciências Humanas da Universidade de São Paulo), p.10. 
“economia mista", como modo de produção que regularia os preços em conformidade com aspirações dos grupos sociais que compõem a sociedade ${ }^{175}$.

HIRANO \& ESTENSSORO comentam que no Japão, a intensificação do desenvolvimento econômico, com distribuição de renda relativamente igualitária, foi impulsionada pela progressão dos recursos humanos relacionada às oportunidades sociais. Os autores concordam com AMARTYA SEN, entendendo que tais oportunidades foram geradas principalmente nas áreas da educação básica e da saúde, entre outras. Dessa forma, a existência de um sistema planejado de ampliação das oportunidades sociais possibilita a expansão da cidadania. No modo de desenvolvimento angloamericano, ao contrário, o mercado é primordial, tornando-se espaço predominante das atividades econômicas, além de ser formalmente autônomo em relação às esferas social, política e cultural. No modo de desenvolvimento, que inclui o regime de acumulação dependente latinoamericano, o Estado se distancia formalmente do mercado, cabendo-lhe apenas a planificação das políticas públicas ${ }^{176}$.

Assim, a crise social relacionada à pobreza e à desigualdade, segundo os autores, não está ligada apenas aos padrões de inserção internacional, em particular à crise do padrão de acumulação dependente latinoamericano. A crise do capitalismo configura-se antes como uma questão sistêmica, que não pode ser resolvida apenas por políticas de estabilização e crescimento econômico das nações periféricas: trata-se de um problema global, à medida que é possível encontrar concentração de renda e aumento da desigualdade também nos países desenvolvidos. Porém, a crise mundial do capitalismo globalizado repercute de forma diferenciada nas diversas regiões do globo, devido aos distintos modos de desenvolvimento regionais ou "capitalismos regionais"177.

175 HIRANO, S. (2004), p. 10.

176 HIRANO, S. e ESTENSSORO, L. (2006), p. 108.

177 Idem, pp.109-110. 
Os padrões de inserção na economia mundial das regiões periféricas são os responsáveis pela distribuição de renda desigual. Instaurou-se nesses países um regime de acumulação excludente, em que a situação dos excluídos dos benefícios da acumulação se agrava com a inflação, as crises econômicas e a expansão do domínio financeiro. A situação torna-se ainda mais difícil quando se percebe que na América Latina, os sistemas de proteção social são economicamente ineficientes e socialmente injustos, tendo como principal característica o grau de universalização muito fraco. A exemplo dos trabalhadores da economia informal, muitas pessoas permanecem excluídas. Além disso, os sistemas não são uniformes, pois seus benefícios são extremamente diferenciados de acordo com o grupo social ou a região ${ }^{178}$. Para os autores, o resultado econômico dessas "políticas assistencialistas, privatizantes e descentralizadas" é que, "apesar da diminuição provisória do empobrecimento, ocorria uma consolidação e aprofundamento da desigualdade social e nenhuma redução da pobreza absoluta" ${ }^{\prime 179}$.

Para compreender o modelo de desenvolvimento japonês é importante destacar o papel da cultura social que favoreceu o desenvolvimento da estrutura de poder da forma como ela se deu, influenciando as organizações que surgiram nesse processo, como também a criação do sistema de oportunidades sociais. A cultura organizacional das empresas, o toyotismo e o trabalho em equipe têm a ver com os valores asiáticos. Dessa maneira, segundo HIRANO, “a ênfase no grupo, e não no indivíduo, privilegia laços de solidariedade comunitária dentro das fábricas, nas quais prevalece o relacionamento cooperativo entre gerentes e trabalhadores, que operam em equipe numa estrutura descentralizada que valoriza as iniciativas dos trabalhadores, dando maior autonomia 
para tomada de decisão no "chão da fábrica"180. Para o autor, "o modelo de capitalismo japonês-asiático era extremamente inovador, democrático, cooperativo e solidário, ao invés de ser conservador e autoritário"181.

No caso de se considerar somente alternativas dentro do modo de produção capitalista, o modo de desenvolvimento japonês-asiático, com a dinamização do capitalismo desenvolvimentista de Estado na consecução de conquistas nacionais, tais como o crescimento com igualdade social, deve ser considerado, em relação ao contexto latinoamericano, como uma opção histórica com mais justiça social. O modo de desenvolvimento japonês-asiatíco apresenta um sistema de oportunidades sociais e econômicas que o torna mais igualitário, produzindo menores desigualdades sociais e menos pobreza.

Este modelo de desenvolvimento carrega, mesmo dentro do controle da crise financeira mundial, elementos estruturalmente equitativos, onde as metas sociais e coletivas têm preeminência e dominância, como uma marca histórica das sociedades do Leste Asiático. O capitalismo desenvolvimentista de Estado tem um potencial de dinamismo qualitativamente diferenciado. Esse elemento estrutural qualitativamente singular, por razões históricas, está na base da construção de instituições de oportunidades sociais e econômicas, que dão ênfase à educação básica, à assistência de saúde e à implantação de reformas agrárias eficazes. Essas instituições sociais ampliam e facilitam a participação econômica da maioria da população do Leste Asiático ${ }^{182}$.

O capitalismo desenvolvimentista de Estado do Leste asiático revela uma estrutura de poder e uma configuração de classes sociais dominantes que, com suficiente vontade política, direcionaram as economias dessas nações de modo a consolidar melhorias nas condições de vida daquelas sociedades. O regime de

180 HIRANO, S. (2004), p. 10.

181 Idem, p. 11.

182 Idem, p. 129. 
acumulação e padrão de inserção das economias do Leste Asiático é entendido assim como um modelo de crescimento com menos desigualdade social, que se constitui em uma alternativa melhor, com relação à justiça social e ao bem-estar da população, sempre dentro do modo de produção capitalista e até mesmo do modo de desenvolvimento concentrador latinoamericano ${ }^{183}$.

\subsection{Cidadania e trabalho}

Em seminário ${ }^{184}$ ocorrido no Brasil no ano de 1996, CASTEL ${ }^{185}$, logo após uma explanação sobre as transformações da questão social, lançou uma pergunta ao público presente, sobre as repercussões da crise da condição salarial sobre a realidade brasileira. O pesquisador queria saber como eram as formas de coesão social e de solidariedade existentes fora da proteção social garantida pelo emprego. Em comparação com a situação européia, lançou a seguinte indagação: "Em que medida (...) esse modelo da sociedade salarial e sua desagregação permitiu precisar, mais por diferença do que por semelhança, a situação do emprego e do desemprego no Brasil, o lugar do trabalho informal em relação ao trabalho assalariado, a importância das regulações que afetam o mundo do trabalho no Brasil?".

A partir da pergunta, o autor fazia uma comparação entre a situação do povo francês e as condições de vida dos brasileiros: se os franceses gozaram de cidadania plena e assistência universal, na forma de um Welfare State por um longo período,

183 Idem, p. 138

184 Palestra proferida por ocasião do Seminário Internacional “A questão social no contexto da globalização", realizado na Pontifícia Universidade Católica de São Paulo, no período de 14 a 17 de outubro de 1996.

185 CASTEL, R. (2004). As transformações da questão social. In: CASTEL, Robert et alli (orgs). Desigualdade e a questão social. São Paulo: EDUC, $2^{\circ}$ edição, versão ampliada. 
estavam perdendo essas garantias devido à crise econômica mundial e à reestruturação produtiva; já os brasileiros nunca tiveram os mesmos privilégios. A indagação era sobre a experiência da pobreza, da exclusão, do desemprego, do subemprego, do trabalho precário, desde sempre tão comum em nossa realidade. Havia interesse em entender as redes de proteção e solidariedade existentes fora do mercado, que contribuíam para a coesão social. Não pretendemos analisar a construção do Estado Social no país, mas enfocar a cidadania e os direitos sociais dos trabalhadores que vivem à margem da proteção legal.

Os efeitos da reestruturação produtiva e da precarização estão instalados entre nós da mesma forma que se encontravam no quadro definido por CASTEL ${ }^{186}$, com a diferença de que na França, a "nova questão social" apareceu, como afirmou o autor, em uma época de "pós-proteções" universais produzidas pela "sociedade salarial". No Brasil, estamos ainda em níveis próximos a uma condição de pré-proteção, baseada em uma rede de políticas públicas nem sempre eficientes e em uma cobertura previdenciária que atingiu apenas uma parcela dos trabalhadores. A informalidade consiste, no modelo brasileiro, na forma mais típica de vinculação ao mercado de trabalho. Tem-se portanto uma situação na qual a precariedade e a ausência de direitos trabalhistas e previdenciários não são a exceção, nem o caso excepcional, mas sim a regra potencial.

Sendo assim, no Brasil percebe-se que nunca formamos uma sociedade salarial segundo o modelo europeu, mais especificamente o francês, definidos por CASTEL. Dessa maneira, não poderíamos falar em "crise de um modelo de Estado que reabre o problema de justiça social e redefine o papel do Estado e o sentido do mesmo da responsabilidade pública"187. Após a década de 1930 tivemos um processo longo de

186 CASTEL, Robert (1998). As metamorfoses da questão social: uma crônica do salário. Petrópolis, editora Vozes, p. 30. 187 TELLES, V. S. (1996). Questão Social: afinal do que se trata?. São Paulo em Perspectiva, 10(4), p. 85. 
extensão de direitos trabalhistas à classe trabalhadora. Esse processo foi seletivo e marcado pelo que SANTOS ${ }^{188}$ chamou de cidadania regulada.

Segundo o autor, a cidadania regulada possuía "raízes que se encontravam, não em um código de valores políticos, mas em um sistema de estratificação ocupacional, onde este sistema era definido por norma legal". Em outras palavras, "eram cidadãos todos aqueles membros da comunidade que estavam localizados em qualquer uma das ocupações reconhecidas e definidas por lei”. Sendo assim, “ a cidadania estava embutida na profissão e os direitos do cidadão restringiam-se aos direitos do lugar que ocupava no processo produtivo, reconhecido por lei. Tornavam-se pré-cidadãos, assim, todos aqueles cuja ocupação a lei desconhecia”.

Segundo SANTOS, a ampliação dos direitos sociais estava diretamente relacionada ao sistema de estratificação ocupacional, pois eram "a regulamentação das profissões, a carteira profissional e o sindicato público os três parâmetros no interior dos quais a cidadania era definida" ${ }^{189}$. Os direitos dos cidadãos decorriam dos direitos das profissões e as mesmas só existiam via regulamentação estatal através da carteira de trabalho ${ }^{190}$. Dessa maneira, o Estado voltou-se para a política social e a então gerada ordem da cidadania regulada iria condicionar o sistema de desigualdades decorrentes da política oficial de previdência e o desenvolvimento de um conflito político e intraburocrático.

A cidadania no Brasil foi fortemente influenciada pela regulação do trabalho e pela disciplina imposta ao trabalhador urbano sob a tutela do Estado. Por interesses econômicos e de classe, o Estado impôs uma legislação trabalhista que, salvo todas as suas incorreções e elementos autoritários, contribuiria, de maneira ambígua, para

188 SANTOS, W. G. (1979). Cidadania e Justiça: a política social na ordem brasileira. Rio de Janeiro: Ed. Campus, p. 75. 189 SANTOS, W. G. (1979), p. 76

190 Os benefícios sociais para a classe trabalhadora eram: férias, salário mínimo, repouso remunerado, regulamentação do trabalho do menor e da mulher, aposentadoria e previdência social. 
impulsionar a associação de classes profissionais em sindicatos por categorias e a participação do trabalhador na vida política do país num sentido mais amplo. Da era Vargas até recentemente, o trabalhador urbano que não portasse a carteira de trabalho como comprovante de sua ocupação profissional corria o risco de ser preso na rua quando abordado por um policial. Desse modo, era o "Estado quem definia quem era e quem não era cidadão, via profissão"191.

A associação entre cidadania e ocupação fez com que em nossa sociedade os direitos sociais fossem considerados privilégios para certas categorias profissionais em comparação com outras; e com que muitas vezes fossem entendidos como realização de uma expectativa de consumo. Sendo assim, o aparecimento de direitos de cidadania no Brasil obedeceu não a uma lógica de adoção de um código de valores políticos universalistas, mas à de um sistema social estratificado, no qual esses direitos compareceram com o objetivo principal de mediar conflitos, por vezes insustentáveis, entre imperativos da acumulação capitalista e anseios de equidade.

Ao contrário dos critérios universalistas, para TELLES a cidadania regulada "tratava-se de direitos que, indexados ao trabalho regular, possuíam em sua própria definição, o princípio que exclui um formidável e hoje crescente contingente de trabalhadores que transitavam entre o desemprego, inatividade, subemprego e as várias formas de trabalho precário no assim chamado mercado informal, que não têm acesso às garantias sociais e que estavam fora de arenas de representação sindical”. Por outro lado, no que diz respeito ao mercado de trabalho formal, "os direitos trabalhistas se institucionalizaram como peça de um ordenamento jurídico, mas não se instituíram como valor, prática e referência normativa nas relações sociais, de tal modo que 
puderam conviver tão bem, ao longo da história, com um padrão autoritário e despótico de organização do processo produtivo e o uso espoliativo da força de trabalho"192.

Dessa maneira, no Brasil, a afirmação da cidadania não obedeceu nem a mesma sequência, nem a mesma lógica de outros países, entre eles a Inglaterra, estudada por MARSHALL. O autor definiu cidadania como "um status concedido àqueles que eram membros integrais de uma comunidade", no qual "todos (...) eram iguais com respeito aos direitos e obrigações"193. Ou seja, a cidadania era a relação do indivíduo com o Estado a partir da qual eram conferidos direitos individuais, num movimento em direção à igualdade de condições. Nas sociedades ocidentais contemporâneas, a cidadania é vista, ao menos em teoria, como um status universal, que abarca três tipos de direitos civis políticos e sociais - e todas as obrigações derivadas deles.

O direito civil seria composto pelos direitos necessários à liberdade individual e o direito político diria respeito ao direito de participação no exercício do poder político. Já o direito social, conteúdo para o que MARSHALL denomina como cidadania social, “envolvia todo um conjunto de direitos, que incluiu segurança e bem-estar econômico, o direito de partilhar do conjunto da riqueza social e de viver uma vida civilizada, segundo padrões sociais condizentes. As instituições mais diretamente relacionadas à cidadania social eram o sistema educacional, os serviços sociais, entre outras". Os direitos sociais estariam na própria base dos modernos sistemas de Welfare State ou do Estado de Bem-Estar ${ }^{194}$.

Para SILVA, "o sujeito típico da cidadania social era o cidadão-trabalhador que era um pagador de impostos como um recebedor de serviços". As condições de cidadania dependiam da atividade do trabalhador, ou seja, do trabalho. O trabalho era elemento fundamental, tanto para a formação da identidade do indivíduo no domínio 192 TELLES, V. da S. (1996), p. 87. 193 MARSHALL, T. H. (1967). Cidadania, Classe Social e Status. Rio de Janeiro: Zahar Editores.p.76. 194 MARSHALL, T. H. (1967). P. 78-79. 
privado da família, quanto no espaço público do sistema educacional; por outro lado, constituía-se no principal mecanismo de participação na produção social e no exercício do poder político. Além disso, para "a formação da identidade do trabalhador era necessária a existência de uma ética do trabalho, fundamental para integrar socialmente o indivíduo, desenvolvendo nele o sentimento de responsabilidade social pela internalização do dever de trabalhar e de pertencimento a uma comunidade de produtores"195.

Nas sociedades industriais modernas, a participação do indivíduo na produção social se dá através do mercado de trabalho, um espaço institucional onde o trabalhador, como proprietário de força de trabalho, vende sua mercadoria, integrando-se ao sistema de produção social como trabalhador assalariado. Mas é justamente na esfera da produção, onde o trabalho constitui uma fonte de poder social, que entram em pauta os temas da liberdade de associação e do direito ao trabalho. A liberdade de associação é um direito civil e político. Já a idéia do direito ao trabalho como direito civil está vinculada ao modelo liberal, contrária à ação reguladora do Estado no mercado de trabalho.

SILVA destaca a relação entre o direito ao trabalho e o dever de trabalhar, já referido por MARSHALL em sua teoria. O dever de trabalhar estaria relacionado à cidadania ativa, baseada numa ética de responsabilidade. A cidadania ativa é tipicamente política, de forma que o dever de trabalhar, visto como o outro lado do direito ao trabalho, pode ser conhecido como direito político de participar do processo de produção social. Apesar disso, SILVA pontua que a noção que parece predominar nos debates sobre desemprego é a de direito ao trabalho como direito social.

195 SILVA, Josué Pereira da (2008). Trabalho, cidadania e reconhecimento. São Paulo: Annablume, p. 82. 
De acordo com SILVA ${ }^{196}$, o conceito de direito ao trabalho é chave importante para abordar a relação entre trabalho e cidadania. A própria questão do direito ao trabalho e ao emprego é controversa, na medida em que na própria Declaração dos Direitos dos Homens e do Cidadão, projeto formulado durante a Revolução Francesa, ao final do século XVIII, já se falava no direito que cada cidadão tinha de viver de seu próprio trabalho. O direito ao trabalho aparecia na verdade como um dever de trabalhar, como maneira de solucionar os problemas de mendicância e pobreza naquele contexto.

O trajeto seguido pela cidadania no Brasil tem sido perpassado por determinados fenômenos, tais como uma dissonância entre cidadania formal (jurídica) e cidadania efetiva; a regulação social; e a presença de retrocesso em determinados períodos históricos. Nessa perspectiva, foi possível verificar não apenas um movimento histórico diverso do relatado no esquema marshalliano, mas a persistência de um sistema social marcado pelo desnível entre os diversos segmentos sociais, compostos por cidadãos supostamente iguais. Era a presença dos "cidadãos de segunda categoria" que, ao contrário dos "cidadãos de primeira classe", deviam se contentar com o rigor da lei e com o consolo de saberem-se acima de enorme massa de não-cidadãos e sub-cidadãos, excluídos dos direitos de cidadania.

Somente nos anos 70, foram incorporados à previdência os trabalhadores autônomos em geral, os trabalhadores domésticos e os trabalhadores da agricultura. Incorporação esta feita sob o marco contributivo. Ou seja, têm direito a uma parca cobertura previdenciária aqueles que contribuem mensalmente; os não-contribuintes nada possuem como direito assegurado e podem somente recorrer à política de assistência, que é pouco articulada e de mínima cobertura no país. Devemos reconhecer que nos últimos anos, o governo tem feito um esforço para ampliar a cobertura e

196 SILVA, Josué Pereira da (2008), p. 84. 
diversas políticas sociais que, apesar de apresentarem resultados positivos, não solucionaram a enorme desigualdade socioeconômica existente no país ${ }^{197}$.

Destaca-se que esse processo de cidadania regulada não permitiu o ingresso na "sociedade salarial", pois entre nós a presença de um setor terciário informal sempre foi marcante. Este setor informal, ao longo da segunda metade do século XX, foi classificado por nossas Ciências Sociais de duas formas: primeiro, como um resíduo, apesar de, em grande proporção, haver uma dualização da economia em dois setores mais amplos - um moderno e capitalizado, mais vinculado à indústria; outro arcaico, descapitalizado e vinculado à prestação de serviços desqualificados. Em segundo lugar, o setor terciário informal é visto como um processo diretamente funcional ao "modo de acumulação urbano adequado à expansão do sistema capitalista no Brasil”198.

Nesta segunda acepção, o terciário descapitalizado é visto, por um lado, como absorvedor de massas trabalhadoras não-integradas ao mercado de trabalho formal urbano, que lá ficariam garantindo seus mínimos patamares de reprodução e pressionando numericamente o mercado formal de mão-de-obra, possibilitando a manutenção de uma estrutura salarial rebaixada. Por outro lado, entende-se que ele fornece às massas urbanas, absorvidas ou não pelo mercado formal de força de trabalho, bens e serviços originados de processos de produção descapitalizados e que demandam, para sua rentabilidade, baixos custos iniciais e consequentemente baixo custo final.

Esse mercado, qualitativamente rebaixado, para o consumo dos trabalhadores urbanos, possibilitaria também a manutenção de uma lógica salarial deprimida. Sem entrar no mérito desta discussão, o fato é que o trabalho assalariado, embora se tenha tornado majoritário no país, não chegou aos patamares franceses de incorporação de

197 Ver ESTENSSORO, L. H. (2003). Capitalismo, desigualdade e pobreza na América Latina. Tese de Doutorado. Faculdade de Filosofia, Letras e Ciências Humanas, Universidade de São Paulo, 289 pp. 198 OLIVEIRA, F. de (2003). Crítica à razão dualista. São Paulo: Boitempo Editorial, p. 34. 
$80 \%$ da PEA em $1975^{199}$. Nesse sentido, se não chegamos a uma sociedade salarial como a francesa, estamos atravessando, ainda assim, a crise do assalariamento. Podemos dizer que com o desemprego, a taxa de assalariados deve ter diminuído, ou que houve aumento de assalariados com vínculos de trabalho atípicos.

É importante ressaltar que o trabalho assalariado no Brasil não é sinônimo de trabalho formal, ou emprego com coberturas previdenciárias definidas por lei. Os dados do IBGE (2000) mostram que entre os trabalhadores assalariados no Brasil, somente $62 \%$ estão cobertos pela previdência social. Muito mais preocupante é o fato de apenas 42\% da População Economicamente Ativa (PEA) no país estar protegida. Ao potencial de desproteção, estão aqueles que atuam como empregados domésticos, trabalhadores por conta-própria e trabalhadores autônomos.

Apesar da taxa de informalidade ter apresentado uma pequena redução nos últimos anos, ela continua significativa. Faz-se necessário ressaltar o crescimento das práticas informais como estratégia de sobrevivência nas regiões metropolitanas ${ }^{200}$. Esse contingente de trabalhadores vem sendo acrescido, nos últimos anos, dos novos excluídos do mercado do trabalho, por conta do efeito de crise econômica e da reestruturação produtiva. Fora dessa espécie de direito contratual, que articula trabalho e proteção social, há uma população excluída não apenas dos benefícios sociais, mas também da cena política.

Além dos dados estatísticos, que ocultam diferenciações e clivagens internas ao mercado de trabalho, é importante destacar: a precariedade intrínseca à própria atividade dos trabalhadores informais, autônomos e por conta-própria, frequentemente executada de maneira improvisada para mobilizar recursos e aproveitar oportunidades, de modo geral, descontínuas e incertas no mercado; as atividades ilegais, em meio às quais se

199 CASTEL, Robert (1998). As metamorfoses da questão social: uma crônica do salário. $\quad$ Petrópolis, editora Vozes, p. 514. 200 IPEA (2006). Brasil: o estado de uma nação - mercado de trabalho, emprego e informalidade. Rio de Janeiro. 
estruturam os segmentos do mercado, no qual transitam os trabalhadores sem carteira de trabalho; a violência a que esses indivíduos estão sujeitos; as demissões no núcleo organizado da economia, atingindo sobretudo o pessoal mais desqualificado; a existência de trabalhadores terceirizados ou prestadores de serviços nas empresas mais modernas, que passaram pelo processo de reestruturação produtiva; a crescente utilização de formas variadas de contrato temporário e subcontratação; e enfim, as velhas e novas formas de trabalho precário e a fragilidade dos vínculos de trabalho e de sociabilidade ${ }^{201}$.

Em meio aos novos padrões de organização do processo produtivo, é possível perceber por exemplo as oportunidades desiguais de atingir melhores colocações no mercado e as desigualdades de salário, dependendo do tipo de vínculo de trabalho. A questão dos salários nas ocupações menos qualificadas, a instabilidade no emprego e a possibilidade do desemprego interferem no estilo de vida. Percebe-se que um contingente crescente de trabalhadores encontra-se em situação de pobreza. Para esses indivíduos, o sindicato não existe, a lei praticamente não funciona, os direitos são inacessíveis e a rotatividade, alta. Sendo assim, o mercado de trabalho aparece segmentado e diferenciado, com setores com categorias profissionais mais organizadas e modernas e setores em que não há qualquer forma de proteção ou benefícios, em que prevalecem as péssimas condições de trabalho e a insegurança dos empregos.

A desigualdade de acesso aos serviços de saúde, à educação, ao trabalho, à moradia, à alimentação, à aposentadoria e a benefícios torna-se cada vez mais evidente dentro da política econômica neoliberal. A diferenciação da cidadania, segundo TELLES, ocorre entre os que têm acesso aos serviços fornecidos pelo mercado e aqueles que são destinados aos precários serviços públicos estatais, visto cada vez mais

201 TELLES, V. S. (1996), p. 88 
como "coisa de pobre", isto é, "signo de incompetência ou fracasso daqueles golpeados pelos azares do destino, que não puderam ou não souberam provar suas virtudes empreendedoras no mercado"202.

Entre as políticas públicas de emprego do governo, devemos ressaltar a política de inclusão dos autônomos, daqueles trabalhadores por conta-própria e proprietários de pequenos negócios, por exemplo, através da Lei do Microempreendedor ${ }^{203}$ Individual, sancionada em julho de 2009 no Brasil. O objetivo dessa iniciativa seria de organização, regularização e qualificação desses trabalhadores para o mercado. No entanto, a medida pode ser considerada de pouca eficácia, pois as estatísticas oficiais demonstraram que a maioria das pequenas empresas fracassa já no primeiro ano de existência. Não podemos negar o problema de gestão de negócios, dos impostos e da carga tributária alta. Porém, podemos considerar que os principais entraves estão ligados ao contexto mais amplo da política econômica nacional e internacional.

A idéia do "empreendedorismo" e da "empregabilidade" faz parte da política econômica do Estado neoliberal. Segundo TELLES ${ }^{204}$, "o mercado era o único e exclusivo princípio estruturador da sociedade e da política, que diante de seus imperativos nada há a fazer a não ser administrar tecnicamente suas exigências, que a sociedade deve a ele se ajustar e que os indivíduos, agora desvencilhados das proteções tutelares dos direitos, podem finalmente provar suas energias e capacidades empreendedoras". Da mesma maneira, podemos questionar os cursos de qualificação oferecidos pelo governo e sindicatos aos desempregados. A formação profissional não significava necessariamente conseguir vagas e nem a permanência no mercado de

202 TELLES, V. S. (1996), p. 91

203Nesse caso, os profissionais de 60 categorias poderiam se cadastrar pagando um imposto único de pouco mais de R\$50 por mês. Eles passariam a dar nota fiscal e teriam direito a auxílio-maternidade, auxílio-doença, aposentadoria e outros benefícios. Além disso, existiu a proposta de incentivo ao crescimento dos negócios, através de empréstimos financeiros em bancos, e a possibilidade de geração de emprego. Por falta de informação, muitos sujeitos não estavam aderindo ao programa e continuavam trabalhando na informalidade. Apesar de importante, essa lei possibilitava cobertura apenas para os indivíduos que faturavam até R\$ 36 mil por ano. Esse critério poderia ser aplicado para uma parcela pequena dos trabalhadores informais. 204 Idem, p. 86. 
trabalho. Mais uma vez, o insucesso era imputado ao trabalhador, como se fosse o único responsável pelo seu "destino". Nesse sentido, as causas econômicas e políticas do desemprego e da precarização do trabalho não eram atingidas.

As políticas econômicas atuais implicam numa inclusão precária, instável e marginal. Para MARTINS, essas políticas não são propriamente políticas de exclusão, mas sim "políticas de inclusão das pessoas nos processos econômicos, na produção e na circulação de bens e serviços, estritamente em termos daquilo que é racionalmente conveniente e necessário à mais eficiente (e barata) reprodução do capital. E, também, ao funcionamento da ordem política, em favor dos que dominam. Esse é um meio que claramente atenua a conflitividade social, de classe, politicamente perigosa para as classes dominantes"205.

MARTINS alerta para o crescimento no Brasil de outra sociedade enquanto "sub-humanidade" isto é, "uma humanidade incorporada através do trabalho precário, no trambique, no pequeno comércio, no setor de serviços mal pagos ou, até mesmo, escusos, etc.”. Sendo assim, “o conjunto da sociedade já não é a sociedade da produção, mas a sociedade do consumo e da circulação de mercadorias e serviços. Portanto o eixo de seu funcionamento sai da fábrica e vai para o mercado". Para o autor, a subhumanidade baseia-se em "insuficiências e privações que se desdobram para fora do econômico". Nesse contexto, "as pessoas podem ter dinheiro (muito dinheiro decorrente de atividades ilícitas, por exemplo) mas estão à margem”. Para os pobres, não existe justiça; eles são "tratados como cidadãos de segunda categoria". Percebe-se que na atualidade, novamente, se cria "uma espécie de sociedade de tipo feudal, sendo que as pessoas estão separadas por estamentos e categorias sociais rígidas"206.

205 MARTINS, José de Souza (1997). Exclusão social e a nova desigualdade. São Paulo: Paulus, p. 20. 206 Idem, p. 36. 
Se a definição estritamente corporativa de cidadania pode ser considerada ultrapassada, não podemos esquecer que "as marcas da origem deixavam revelar seus efeitos na cultura política desse país e na armadura institucional dos direitos sociais. A persistência de uma percepção dos direitos como doação de um Estado protetor seria inexplicável sem essa peculiar experiência de cidadania dissociada da liberdade política, como valor e como prática efetiva, e que se reduz, ao acesso aos direitos sociais".

Para TELLES, “o que importa não era a eficácia dos direitos naquilo que eram capazes ou não de garantir em termos de benefícios reais, mas a natureza do vínculo que eles constroem entre as classes e entre essas e o Estado"207. A obrigatoriedade do vínculo ocupacional significa que os acessos aos direitos sociais se dissociam, na prática, de uma condição inerente de cidadania. Além disso, pelo fato dos benefícios serem vinculados ao valor das contribuições fixadas a partir da renda adquirida através do trabalho, os benefícios garantidos pelo Estado terminam por reproduzir um perfil das desigualdades sociais. Dessa maneira, a universalidade da lei que garante a todos a proteção social consagra desigualdades e anula na prática os efeitos redistributivos e compensatórios que supostamente são objetivos das políticas sociais. O "direito contratual", no caso brasileiro, acaba neutralizando a questão da igualdade ${ }^{208}$.

De acordo com a autora, mais do que limitações de um determinado sistema de contribuição e financiamento de previdência, o que importa é enfatizar "o quanto esse fato carregava de uma tradição na qual os direitos sociais não eram formulados do ângulo das desigualdades sociais que eles supostamente deveriam compensar". A autora observa o período atual à luz da história, recorrendo ao momento de criação dos direitos sociais, nos anos 30. Ainda segundo TELLES, tais direitos "não foram criados na perspectiva do indivíduo-cidadão que encontrava neles um recurso para compensar as

207 TELLES, V. S. (1992). Cidadania inexistente: incivilidade e pobreza; um estudo sobre trabalho e família na grande São Paulo. Tese de Doutorado. Faculdade de Filosofia, Letras e Ciências Humanas da Universidade de São Paulo, 335 pp. 208 Idem, p. 38. 
vicissitudes da vida social que o comprometeriam como indivíduo autônomo e soberano nas suas prerrogativas de cidadão"209.

O ordenamento corporativo existente na sociedade determina o vínculo da mesma com o Estado. Nessa matriz, os direitos sociais se definiram e foram institucionalizados na sociedade brasileira. O Estado retribuía na medida da contribuição de cada indivíduo, formalizando no mundo público da lei uma matriz privada, na qual as garantias contra a doença, os acidentes de trabalho, a invalidez e a velhice dependiam inteiramente da capacidade de cada um de conquistar o seu lugar no mercado de trabalho. Atribuía-se aos indivíduos toda a responsabilidade por seu próprio destino. A perda dos meios de sobrevivência era associada a seus atos, vontades e competências. É importante ressaltar digno de nota que apenas recentemente admitiu-se a necessidade do seguro-desemprego no país ${ }^{210}$.

Com o esgotamento dos modelos conhecidos de proteção social e regulação do trabalho, foram reativados os "sentidos de aporias, contradições, tensões e conflitos" que estiveram nas origens desse problema. TELLES defende a necessidade de se "desvencilhar dos fetiches dos modelos e reativar o sentido político corporificado em armaduras institucionais nas quais se estabeleceram as mediações entre o mundo do trabalho e a cidadania. Sentido político ancorado na temporalidade própria dos conflitos através dos quais os trabalhadores se destacaram e (...) constituíram-se como atores coletivos, ganharam a cena pública e disputaram, negociaram, arbitraram os termos de sua participação social" ${ }^{\text {211 }}$.

Nesse caso, segundo a autora, “o que se especifica era um modo de regulação das relações de trabalho subtraídas das formas de representação (fabril e sindical)". TELLES destacou a constituição dos grupos de operários como "atores coletivos,

209 Idem, p. 38.

210 TELLES, V. S. (1992), p. 39.

211 TELLES, V. S. (1996). Questão Social: afinal do que se trata? São Paulo em Perspectiva, 10(4), p. 85. 
portadores de uma palavra que desprivatizava a realidade fabril e titulares de direitos reconhecidos (e conquistados) como parâmetros de uma regulação democrática das relações de trabalho, mediada pelas categorias universais da cidadania"212.

$\mathrm{PAOLI}^{213}$ analisou as lutas operárias travadas nas fábricas na década de 30 para reivindicar melhores condições de trabalho, salários, redução das jornadas, férias e leis de proteção ao menor e à mulher, entre outros direitos, e que fizeram parte da construção de cidadania ativa. Nessa perspectiva, os direitos sociais eram fruto de reivindicações políticas e não apenas uma concessão do Estado para classe trabalhadora.

A pesquisadora destaca a experiência política de integração social, cujo espaço é feito de práticas múltiplas em contraposição ao papel isolado do Estado, dizendo que “(...) por maior que tenha sido o efeito de legitimidade desse discurso estatal protetor, seus destinatários não eram pessoas sem história, sem trajetos, sem biografia, sem interioridade, sem experiência de sociedade e de cultura. Por isso, este discurso estatal era o lugar onde a multiplicidade de significados se reunia e se concretizava no encontro de vários sentidos, de várias tradições, de várias contestações”. Segundo a autora, "sem isso, não era possível perceber no que a experiência social e sua expressão coletiva se afastavam desta 'cidadania regulada'; em que lugar a fala do poder ignora, sufoca e destrói a sua própria idéia de constituir cidadãos e de mudar o horizonte desintegrado de uma nação"214.

A questão da cidadania plena e livre, ao contrário da cidadania regulada pelo Estado, é questionada por RODRIGUES. O autor chama a atenção para a "cidadania na fábrica" ou a "cidadania econômica". Nesse caso, "mesmo adquirindo todos os direitos civis, políticos e sociais, o trabalhador, principalmente o operário da indústria moderna,

212 Idem, p. 87.

213 PAOLI, M. C. (1989). Trabalho e Cidadania. Experiência do Mundo Público da História do Brasil Moderno. Revista de Estudos Avançados, vol. 3, nº 7, pp. 40-66.

214 PAOLI, M. C. (1989), p. 65 
dentro da empresa estava submetido a um sistema de autoridade". Seria necessário pensar numa "cidadania do trabalhador na empresa", ou seja, "uma parte da cidadania que envolvia os direitos do trabalhador; isto é, todos aqueles direitos que estavam relacionados com a limitação da autoridade gerencial (tanto nas empresas privadas como nas estatais) ${ }^{215}$. Dessa maneira, seria fundamental que o trabalhador cultivasse em sua vida de trabalho uma participação maior no conjunto de decisões que o afetavam diariamente.

RODRIGUES também observou o processo de reorientação do movimento sindical para o interior das fábricas no final da década de 70 . Tal movimento não se limitou a reivindicações mais gerais e habituais, como reajustes salariais, mas tratou de colocar um conjunto de questões que afetavam o sistema de relações internas à empresa. Segundo o autor, as comissões de fábrica, instituições de representação dos trabalhadores que não estavam subordinadas à estrutura sindical oficial tinham a proposta de "limitar a autoridade patronal, aumentar o poder de os trabalhadores influenciarem certas decisões ou certos aspectos da vida da empresa que estão fundamentalmente ligados à vida cotidiana do trabalhador na fábrica (...). A comissão era algo que (...) vem e toca um aspecto, às vezes deixado de lado, da dignidade do trabalhador, de este não ser um mero objeto de que a gerência dispõe" ${ }^{216}$. Esse seria um dos caminhos de se conquistar a cidadania livre e plena, na visão do pesquisador.

A importância da comissão de fábrica também é apontada por HIRANO et alli. como instrumento de poder dos trabalhadores para interferir no controle do planejamento, da organização e nas condições de trabalho, saúde, higiene e segurança no trabalho. O sociólogo enfatiza a importância da responsabilidade civil e patronal - e não apenas do Estado em relação aos casos de acidentes de trabalho e doenças

215 RODRIGUES, Leôncio Martins (1986). A Cidadania do Trabalhador Urbano. In: TEIXEIRA, João Gabriel Lima Cruz. A construção da cidadania. Brasília: Editora Universidade de Brasília, p. 11-12. 
profissionais. A proteção e maior segurança no mundo do trabalho dependem da alteração da autoridade gerencial, restringindo-a no sentido de possibilitar a ampliação da participação do trabalhador no sistema decisório no âmbito da empresa ${ }^{217}$. Sendo assim, a conquista da cidadania pelo trabalhador dentro da empresa significa que as melhorias das condições de trabalho, devido à organização e ao controle da autoridade gerencial, somente pode ser revertida em termos de direito à segurança, à higiene e à saúde através da mobilização do trabalhador dentro do mundo do trabalho.

HIRANO et alli. identificam a condição de trabalhador acidentado como a de um "cidadão se segunda classe" na passagem por várias instituições voltadas à reparação, recuperação e reabilitação. O sujeito se torna um "cidadão pela metade, na qualidade de dependente, sem autonomia e liberdade, e sempre desigualmente atendido quanto ao mínimo necessário à higiene e à segurança no cotidiano da fábrica e fora dela e no interior de outras instituições de saúde que teoricamente estariam a serviço dos vários segmentos da sociedade" ${ }^{218}$. Nessa perspectiva, a via crucis do trabalhador quanto ao direito social, ou seja, direito à saúde, inicia-se quando ele se acidenta, passa pela recuperação e reabilitação e vai até o retorno ao trabalho.

Outra questão fundamental é a responsabilidade civil pelos acidentes de trabalho. Nesse caso, cabe aos empresários o pagamento de indenização às vítimas ou herdeiros, que receberiam, além do benefício previdenciário, um complemento indenizatório correspondente ao dano sofrido $^{219}$. Essa medida procurava amenizar os danos, restaurando através do benefício de indenização a condição mínima de sobrevivência e de dignidade da família do trabalhador, oferecendo-lhe uma tênue esperança de reorganização da sua vida. $\mathrm{Na}$ análise da trajetória de acidentados do

217 HIRANO, S.; REDKO, C. P. \& FERRAZ, V. R. T. (1990). A cidadania do trabalhador acidentado: (re)conhecimento do direito aos direitos sociais. Tempo Social; Rev. Sociol. USP, São Paulo, 2(1): 127-150, $1^{\circ}$ semestre, p. 128. 218 Idem, p. 135. 
trabalho no âmbito da família e empresa, MATSUO ${ }^{220}$ percebeu o desrespeito aos direitos dos trabalhadores em relação à assistência médica, à assistência social e à assistência previdenciária entre outros.

MATSUO ressalta que a maioria das famílias dos trabalhadores entrevistados passava tanto por dificuldades financeiras, devido ao valor baixo do seguro-acidente ou auxílio-doença, como por problemas psicológicos, devido ao trauma e aos conflitos emocionais que refletiam no companheiro ou companheira e nos filhos. Eram comuns os casos em que os sujeitos eram reinseridos no trabalho sem terem passado por um processo de reabilitação física, mental e profissional adequado. A inclusão precária fazia com que, muitas vezes, os trabalhadores sofressem novos acidentes ou fossem vítimas de assédio moral e humilhação por parte da empresa. Durante o período de afastamento do trabalho, inúmeros acidentados foram obrigados a realizar "bicos" e atividades informais para complementar a renda proveniente do seguro-acidente. Devido à ausência do Estado, os sujeitos precisavam contar com a ajuda de familiares, amigos e da vizinhança para conseguir sobreviver.

Quanto aos trabalhadores informais, tema deste trabalho, eles não são indivíduos que estão fora do mercado e da vida social organizada. Estão no lugar em que não existe mediação pública dos direitos e de representação. Formam, segundo TELLES, uma “classe inacabada", perdendo-se na invisibilidade social. Diante da avalanche neoliberal dos anos 90, a questão que se apresentava era de "refundar o horizonte de legitimidade dos direitos", segundo a autora.

Além disso, as transformações na economia estão nos colocando em uma fronteira de dilemas que "escapam a conceitos, fórmulas políticas conhecidas" e que 
estão a exigir a "reinvenção dos termos para se pensar as relações entre trabalho, direito e cidadania”. Está na ordem da invenção democrática e da refundação política, como espaços de criação e generalização de direitos, uma necessária redefinição entre o econômico e social e o controle democrático do mercado. 


\section{CAPÍTULO 3: A PESQUISA SOBRE TRABALHADORES DESEMPREGADOS E INFORMAIS: NO MAR, NO CAMPO E NA CIDADE}

\subsection{O trabalho de campo}

Os vendedores ambulantes foram observados e entrevistados no primeiro momento deste estudo, isto é, na fase da pesquisa exploratória pela própria pesquisadora. Na segunda fase, a maioria dos camelôs foi entrevistada por uma estagiária, então estudante universitária. Nessa mesma fase, a pesquisadora realizou estudos com pescadores de lagosta, colhedores de laranja e catadores de materiais recicláveis. Foram realizadas 60 entrevistas individuais, sendo 44 com homens e 16 mulheres, entre catadores de materiais recicláveis, vendedores ambulantes e colhedores de laranja. No caso dos pescadores de lagosta todos os entrevistados eram homens. As três entrevistas coletivas contaram com a participação de 100 pescadores ao todo.

\subsubsection{Experiência no mar: pescadores de lagosta}

O trabalho de campo sobre os pescadores de lagosta ocorreu no mês de maio de 2008. A pesquisadora participou de uma operação do Grupo Móvel do Trabalho Aquaviário (Fiscalização da Pesca da Lagosta) do Ministério do Trabalho e Emprego, na região oeste do litoral do Ceará, nas cidades de Itarema, Acaraú e Aranaú. O objetivo 
foi verificar as questões trabalhistas ${ }^{221}$, como o registro em carteira de trabalho dos pescadores e trabalhadores das indústrias de pescado na região e os registros dos barcos de pesca. Além disso, existiu a preocupação de perceber as condições de saúde e segurança no trabalho dos pescadores de lagosta.

Como em situação anterior houve ocorrência de conflito com os proprietários de barcos - os chamados armadores -, dois policiais federais tiveram de ser acionados para escoltar a equipe formada por quatro auditores fiscais da Superintendência Regional do Trabalho do Rio Grande do Norte, de Santa Catarina, do Rio de Janeiro e do Ceará e pela pesquisadora, socióloga e psicóloga da Fundacentro/Centro Técnico Nacional de São Paulo/ Ministério do Trabalho e Emprego. Se por um lado, a presença dos policiais oferecia segurança para a equipe, por outro deixava os proprietários dos barcos apreensivos e evasivos.

Em primeiro lugar, nos dirigimos a vários atracadores situados na foz do Rio Acaraú. Sempre era possível encontrar um ou outro pescador dentro do barco. Estavam preparando a embarcação e cuidando da manutenção, já que o período de defeso ${ }^{222}$ estava terminando e em poucos dias partiriam para iniciar a pesca da lagosta. Com a nossa aproximação, os pescadores procuravam sair rapidamente do local de trabalho para não se comprometerem com o trabalho da fiscalização, pois temiam qualquer represália por parte dos donos dos barcos. Aqueles que permaneciam procuravam falar o mínimo possível com a pesquisadora e os auditores fiscais. Percebeu-se a existência de um pacto de silêncio entre os donos dos barcos, pois logo que chegávamos a um local a notícia se espalhava rapidamente, deixando precavidos os armadores na cidade.

221 Diante do alto índice de informalidade, a estratégia adotada pelo MPT ( Ministério Público do Trabalho) tem sido reunir trabalhadores da pesca por regiões e promover Termos de Ajustamento de Conduta (TACs) com os donos de barcos para viabilizar o registro dos trabalhadores, com o apoio da fiscalização do MTE (Ministério do Trabalho e Emprego). 
A maioria dos trabalhadores não foi aversiva à nossa aproximação, mas em geral eles mantinham conduta evasiva e desconfiada no início. Talvez porque os representantes do Ministério do Trabalho estivessem escoltados pela Polícia Federal. Depois de um tempo, percebendo que nossa intervenção não tinha caráter repressor, grupos de pescadores que permaneciam próximos às embarcações aceitaram manter entrevista aberta com a pesquisadora. Os trabalhadores foram escolhidos de maneira aleatória. Enquanto isso, os auditores fiscais procuravam verificar os nomes das embarcações, para que depois pudessem averiguar seus registros, documentações, e condições de segurança.

Os grupos pesquisados, formados por homens, variavam de tamanho, contando com dez, 20 e até 70 pescadores de diferentes idades, a maioria entre 18 e 40 anos. Percebeu-se que os trabalhadores sentiam necessidade de falar, criticar, reclamar das condições de trabalho. Como não havia um contrato formal com qualquer instituição de representação dos pescadores, como sindicatos ou colônias, durante a realização da pesquisa as entrevistas transcorreram de maneira tranqüila, descontraída e em espaços neutros, como por exemplo nos cais onde os barcos estavam atracados, o que favoreceu o diálogo entre os pescadores e a entrevistadora. $\mathrm{O}$ foco da pesquisa era ouvir o discurso do trabalhador, independentemente de pertencer ou não à colônia, associação de pescadores ou outros órgãos.

Em algumas situações, um ou dois pescadores viravam portavozes do grupo e em outras, quase todos queriam manifestar opiniões sobre a atividade de trabalho, os direitos, as injustiças e a política, entre outros assuntos. Ficou a impressão de que todos desejavam ser ouvidos, receber atenção e dialogar. A Colônia de Pescador, lugar de reunião dos associados onde se esperava encontrar um espaço de discussão, foi referida como entidade que recebia contribuições mensais dos pescadores para fins de 
aposentadoria (aposentadoria especial); preparava atestados que comprovassem o exercício da profissão; cuidava das questões burocráticas do trabalho; e como local de lazer. Em nenhum momento, as colônias da região foram consideradas como espaços de organização e mobilização política dos pescadores para fins de reivindicação de melhorias nas condições de trabalho e direitos de cidadania, por exemplo.

A pesquisadora se apresentava como representante do Ministério do Trabalho e Emprego e da Fundacentro e iniciava a conversa perguntando sobre a inserção na pesca, a trajetória profissional, sobre o que consistia a atividade da pesca, as condições de trabalho, a renda, a organização, a identidade profissional, as condições de vida e saúde, o que faziam nas horas de repouso, como era o cotidiano de trabalho, entre outros aspectos. A entrevistadora procurou seguir um roteiro de perguntas para facilitar o encaminhamento da discussão. Algumas questões importantes foram sugeridas pelos próprios pescadores na ocasião da pesquisa de grupo.

Os trabalhadores procuravam descrever a atividade com detalhes e esclareciam os termos técnicos de maneira detalhada e compreensível, já que a entrevistadora não tinha familiaridade com o assunto. Era o primeiro contato pessoal com trabalhadores da pesca da lagosta. Eles, mais que ninguém, conheciam a atividade e demonstravam seu saber prático na maneira clara e objetiva de se manifestar. As questões que diziam respeito à vida pessoal dos trabalhadores foram levantadas em particular, em outro momento. Percebeu-se que não eram sujeitos passivos, pois questionavam sobre seus direitos, a divisão dos lucros da produção, suas condições de trabalho e saúde e sua perspectiva de vida. A entrevista consistia em momentos de troca de informações e de produção de conhecimento a partir da realidade social referida pelos pescadores.

Ao caminhar pelas regiões onde os pescadores moravam era possível observar as condições precárias de moradia, saneamento básico, iluminação e das vias públicas, 
como estradas, ruas e rodovias, entre outros aspectos. As cidades eram de pequeno porte e existia pelo menos uma agência bancária, escolas, Unidade Básica de Saúde, igrejas, prefeitura e comércios em geral. Os entrevistados costumavam ir às cidades maiores mais próximas quando preciso, isto é, nos casos de emergência, acidentes, doenças graves e para fazer compras, entre outras necessidades. Os armadores (donos de barcos) viviam na região central, "bairro nobre", enquanto os pescadores residiam nas periferias das cidades, "bairro pobre", próximo aos rios e atracadouros de barcos.

A desigualdade social era gritante quando comparávamos as condições de moradia dos pescadores com as dos proprietários de barcos. Essa observação foi possível, pois a pesquisadora acompanhou os auditores fiscais na entrega do termo de autuação e chegou a entrar em várias residências que ocupavam metade do quarteirão, onde podia ser observada a presença de pisos de mármore, vários carros e motos importadas e azulejos italianos nas piscinas, entre outras ostentações. A maioria dos armadores possuía apartamentos luxuosos nas regiões mais caras de Fortaleza. Eles tinham a tradição de manter os filhos estudando na capital do Ceará. A riqueza podia ser explicada pelo fato dos armadores possuírem frotas de barcos, fábricas de gelo e indústrias de processamento de pescado, trabalharem com a exportação dos produtos e serem donos de comércios na cidade.

Em agosto de 2008, foi realizada uma entrevista de grupo com trabalhadores desempregados da pesca comercial do atum e da merluza no Sindicato dos Oficiais da Marinha Mercante (SINDMAR), na cidade de Cabedelo, no interior da Paraíba. A pesquisadora procurou levantar dados sobre a trajetória profissional dos pescadores, suas condições de trabalho e vida, a experiência do desemprego e estratégias de sobrevivência acionadas por eles. Tal pesquisa possibilitou realizar comparações entre esses trabalhadores e os pescadores de lagosta. Os pescadores de atum desempregados 
estavam vivendo do seguro-desemprego e a maioria realizava "bicos" e atividades informais para complementar a renda. Eles reclamaram da falta de direitos, da insegurança quanto à renda mensal e da dificuldade de reinserção no mercado formal devido à escolaridade baixa, falta de qualificação e idade avançada para determinadas funções na pesca.

Os armadores ou donos de barcos da pesca da lagosta evitavam estar presentes no momento da entrega do termo de autuação em suas residências. Alguns chegavam literalmente a "fugir" de carro quando eram avisados da chegada dos auditores fiscais. Mesmo assim, por determinação legal, acabavam comparecendo frente ao Ministério do Trabalho e Emprego para apresentar as documentações solicitadas pelo órgão. Nessa perspectiva foi impossível entrevistar algum dono de barco, pois todos demonstraram atitude arredia e muitas vezes agressiva. A equipe do Grupo Móvel da Pesca teve que trabalhar escoltada por policiais federais devido às ameaças de represália e violência. $O$ fato de meu trabalho ser de pesquisa e não fiscalização contribuiu para que os pescadores participassem das entrevistas.

Além das entrevistas, a pesquisadora visitou o interior de barcos atracados na beira dos rios - tanto a parte superior, quanto o porão. A partir das visitas, foi possível verificar que as condições em que os trabalhadores dormiam, cozinhavam, faziam as refeições, armazenavam os barris de água para consumo e executavam suas tarefas de trabalho eram precárias. Os seguintes aspectos chamaram a atenção: falta de banheiro e de chuveiro para banho; ausência de mesa para refeição; e o fato da cozinha, do dormitório (beliches) e da cabine do piloto estarem no mesmo espaço. O barco partia para o mar carregado de manzuás ou covos (armadilhas), lanças e bóias. Percebeu-se que quase não existia espaço para os pescadores permanecerem na embarcação. 
Infelizmente, a pesquisadora não pôde participar de uma pescaria, pois a presença de mulheres era proibida e os pescadores iriam permanecer na costa durante longo período.

\subsubsection{Experiência no campo: colhedores de laranja}

A pesquisadora entrou em contato com a Casa de Agricultura $^{223}$ da Regional Limeira da Coordenadoria de Assistência Técnica Integral (CATI) da Secretaria de Agricultura e Abastecimento do Estado de São Paulo. Com apoio de um engenheiro agrônomo, foram realizadas visitas a algumas chácaras com plantação de laranja utilizando carro oficial. Na ocasião, foram encontrados poucos colhedores trabalhando. A maioria se recusou a dar entrevistas. Os trabalhadores afirmaram que "não tinham nada para dizer" e que "estavam ocupados naquele momento". Conforme o carro se aproximava da plantação, os trabalhadores desapareciam em meio aos pés de laranja. Talvez a atitude tenha a ver com o receio da fiscalização do Ministério do Trabalho, que estava pressionando os fazendeiros para a contratação legal dos colhedores de laranja.

A intermediação de mão-de-obra entre os trabalhadores e donos de chácaras e fazendas era feita pelos "gatos" ou "turmeiros". Com certeza, os sujeitos temiam alguma represália caso conversassem com a pesquisadora ou o pessoal da fisscalização. A estratégia foi tentar contato com algum "turmeiro". O engenheiro agrônomo da CATI indicou um sujeito que trabalhava como intermediário de mão-de-obra havia mais de 15

\footnotetext{
223 Coordenadoria de Assistência Técnica Integral (CATI) é um órgão da Secretaria de Agricultura e Abastecimento do Governo do Estado de São Paulo fundado em 1967 para prestar serviços aos produtores rurais.A instituição tem o objetivo de promover o desenvolvimento rural sustentável, por meio de programas e ações participativas com o envolvimento da comunidade, de entidades parceiras e todos os segmentos dos negócios agrícolas. Os serviços e produtos da CATI estão disponíveis aos agricultores e pecuaristas nas Casas da Agricultura, onde engenheiros agrônomos, engenheiros agrícolas, zootecnistas e médicos veterinários prestam informações e orientam o produtor rural na condução de seus negócios agrícolas. Com sede em Campinas (SP), a rede da CATI é composta por 40 Escritórios de Desenvolvimento Rural (EDRs) distribuídos nas várias regiões do Estado de São Paulo. Os 40 EDRs englobam as Casas de Agricultura municipais. http://www.cati.sp.gov.br Consulta realizada no dia 31 de agosto de 2009.
} 
anos. Tinha dez equipes, cada uma com 20 trabalhadores. $\mathrm{O}$ engenheiro comentou que se vinha regularizando a contratação dos trabalhadores, mas que os mesmos resistiam, pois sua renda líquida havia diminuído. Argumentou que os "turmeiros" foram obrigados a baixar o valor da caixa de laranja, pois agora eram obrigados a pagar taxas e impostos ao governo devido à regularização.

Foram realizadas visitas às chácaras para observar o trabalho da colheita da laranja. Devido à inexperiência, a pesquisadora não tomou os devidos cuidados de cobrir todo o corpo com roupas de cor clara por causa do sol forte, utilizar bloqueador solar, chapéu e, principalmente, beber muito líquido, entre outros. Dessa maneira, teve insolação, alergia a agrotóxicos e levou picadas de abelha. Na realidade percebeu que não era uma pessoa do campo. Aliás, foi motivo de gozação por parte dos trabalhadores, que depois ensinaram a entrevistadora como deveria proceder naquela situação.

Nas próximas idas ao campo, a pesquisadora tentou colher laranjas junto aos trabalhadores. A experiência durou pouco tempo. Além da força física, era necessária destreza, rapidez e equilíbrio para ficar de pé sobre os degraus de escadas segurando a sacola transpassada no corpo. A sacola devia ser carregada com até 25 quilos de laranjas da parte superior da árvore e mais 27 quilos da parte inferior. A pesquisadora não tinha os conhecimentos práticos necessários para realizar a tarefa. Ela sentiu medo de cair, não aguentou o peso da sacola, não conseguiu carregar a escada, não sabia escolher as laranjas que deveriam ser colhidas, entre outros problemas. Através da experiência, foi possível perceber que não era necessária apenas força física, mas o "jeitinho", habilidade adquirida com o tempo para realizar o trabalho.

Durante as pausas e o horário de almoço, a pesquisadora tentou entrevistar os colhedores. Paravam para beber água e almoçar e voltavam rapidamente para o trabalho. Não era possível conversar com tranquilidade naqueles momentos. Um dos colhedores 
comentou que era para tomar cuidado, pois as "árvores tinham ouvidos", isto é sempre existia alguém que poderia escutar a entrevista e depois comentar algo com o "turmeiro". Sendo assim, foi feita a sugestão de visitá-los em suas próprias residências. No início demonstraram resistência, pois talvez se sentissem constrangidos com as condições de moradia precárias, ou tivessem receio em relação ao assunto da pesquisa.

Depois que um dos colhedores conversou com o "turmeiro", foi decidido que as próximas entrevistas seriam realizadas nas casas dos trabalhadores. As pesquisas foram feitas durante três finais de semana, no mês de outubro de 2008. Foram entrevistados 15 homens e 5 mulheres. Todos moravam em um bairro conhecido por acolher inúmeros bóias-frias e seus familiares. Em primeiro lugar, a pesquisadora dirigiu-se à residência de um trabalhador, que auxiliou na procura de colhedores de laranja para a pesquisa. Algumas entrevistas foram realizadas próximas aos bares e botequins, pois era onde os colhedores costumavam ficar nos dias de folga. Tomou-se cuidado em relação ao fato do sujeito estar ou não alcoolizado.

A pesquisadora foi bem recebida por todos os entrevistados. Eles não demonstraram qualquer resistência, principalmente por não estarem no ambiente de trabalho. Estavam em seu próprio espaço, junto à família e amigos. Pareciam relaxados, descontraídos, falavam abertamente, contavam histórias, faziam gozações e brincadeiras em relação aos acontecimentos na situação de trabalho e vida. Alguns trabalhadores preferiam conversar na calçada ou na praça de frente à casa. Diziam que o espaço da moradia era pequeno, estava tudo "bagunçado" e sentiam vergonha de mostrar a casa.

Outros trabalhadores faziam questão de que a pesquisadora entrasse na casa, serviam água ou café e não demonstravam qualquer constrangimento. Alguns argumentaram que se a entrevistadora quisesse conhecer como viviam na realidade era preciso ver também as condições de moradia. As casas eram simples e era possível 
observar a existência de eletrodomésticos, aparelhos de som, entre outros objetos. Em duas residências foram encontrados carros velhos parados em garagens improvisadas. Quando o tempo não era suficiente, marcava-se outra data para concluir a entrevista. Não houve nenhuma recusa por parte dos trabalhadores para participar da pesquisa. Pelo contrário, parecia que estavam ansiosos em poder falar de suas experiências de vida e satisfeitos por ter alguém escutando.

\subsubsection{Experiência na cidade: catadores de materiais recicláveis}

As vinte entrevistas com os catadores de materiais recicláveis ocorreram entre julho e agosto de 2008. Os catadores que participaram do estudo eram dos bairros de Santana, Barra Funda, Bom Retiro e Glicério, na cidade de São Paulo. Foram entrevistados 17 homens e 3 mulheres. O início do trabalho de campo foi difícil, pois a pesquisadora não conhecia e nem mantinha contato com catadores nas ruas. Quando tentava se aproximar dos indivíduos, eles estavam em horário de trabalho e não paravam um minuto sequer para conversar. Reviravam freneticamente as lixeiras à procura de materiais recicláveis. Não podiam perder tempo, pois tinham que "correr atrás do lixo" e chegar antes que os outros nas próximas lixeiras.

Após um período de observação do trabalho do catador, a pesquisadora percebeu que eles faziam pequenas pausas durante o desenvolvimento da atividade. Paravam para comer, descansar, tomar um gole de água e arrumar os materiais em cima da carroça, entre outros motivos. Aproveitando desse momento, a pesquisadora iniciou a conversa com um catador. O tempo de pausa costumava ser curto, dez minutos, e quando 
precisavam descansar ou tirar um cochilo debaixo ou em cima da carroça, de cerca de 20 minutos, diziam para não ser incomodados e que não poderiam dar atenção, pois necessitavam dormir para poder continuar o trabalho, extremamente desgastante. Depois disso, a entrevistadora achou melhor realizar a pesquisa enquanto o catador estivesse caminhando.

A pesquisadora tentou acompanhar o trabalho de um catador, o Sr. João, por um dia. A pesquisa participante revelou as dificuldades, as agruras e a satisfação na atividade. O ritmo do trabalho era intenso o que dificultava manter qualquer diálogo enquanto se trabalhava. Caminhava-se de maneira acelerada nas ruas, diminuindo a velocidade apenas nas subidas e descidas. Mantinha-se o foco nos lixos empilhados nas ruas, nas caçambas e no trânsito de automóveis. Todo cuidado era pouco, pois esses trabalhadores poderiam ser atropelados por causa de qualquer descuido (e a própria pesquisadora quase foi atropelada!). Às vezes, se dirigia a determinado prédio, condomínio ou estabelecimento comercial onde haviam reservado o material reciclável para o catador, mas ele mudava de rumo e entrava em ruas diferentes sem ao menos avisar. Era necessário correr atrás do trabalhador.

Percebeu-se que com a experiência, o trabalhador aprendeu a identificar lugares onde era possível encontrar materiais. Então, costumava parar de repente e dizer: "aqui deve ter alguma coisa". Começava a abrir os sacos de lixo, separar o que era interessante e colocar sobre a carroça. Existia uma maneira adequada, uma "técnica" adquirida na prática para empilhar os diferentes materiais sobre a carroça (sendo que algumas chegavam a carregar mais de mil quilos). O Sr. João tomava cuidado para não espalhar o lixo nas calçadas e procurava deixar o ambiente limpo. Ele dizia que os catadores eram conhecidos como "porcalhões" que sujavam as ruas. Ressaltava que ele 
não era "porcalhão", mas alguém que se preocupava com meio ambiente e cuidava da limpeza da cidade.

No início, a pesquisadora teve a experiência de coletar o lixo utilizando um par de luvas que o catador havia tomado emprestado de um conhecido. Não havia máscara que pudesse evitar o odor insuportável em vários momentos. Não era conveniente comentar sobre o cheiro, o lixo em decomposição, o medo de contaminação por material pérfuro-cortante, entre outros problemas. Notou-se que os catadores estavam habituados a lidar com todos os tipos de lixo e não demonstravam qualquer preocupação. Após algumas tentativas frustradas, a entrevistadora deixou de executar a tarefa para não atrapalhar a atividade do carroceiro, contentando-se apenas em observar o trabalho. Percebeu-se que não era necessária apenas força física e agilidade, mas atenção, foco, capacidade de aprendizagem, conhecimento dos tipos de materiais recicláveis e noção básica de matemática (pesos, tamanhos, valores dos materiais, cálculos entre outras).

No dia da pesquisa participante, o catador ganhou roupas e calçados usados de um conhecido e encontrou sobras de material de construção numa lixeira. Após o "garimpo", conseguiu separar alguns materiais que iriam propiciar um ganho significativo. Além disso, conseguiu coletar materiais recicláveis, como papel, papelão, plástico e latinhas de alumínio, entre outros. Enquanto caminhava, fazia os cálculos de quanto poderia obter em dinheiro com a venda dos produtos ao ferro-velho. Disse que a coleta estava razoavelmente boa até aquele momento do dia, pois tinha conseguido alguns materiais de valor maior. Estava satisfeito, até que de repente lembrou com ar de preocupação que a felicidade iria durar pouco, pois durante a noite, quando estivesse dormindo, o dinheiro poderia ser roubado. Falava de maneira resignada, pois já estava acostumado com a situação e não seria a primeira, nem a última vez. 
Após seis horas de caminhada por diferentes ruas e bairros e ter comido "quentinha" (marmitex) com comida fria, sentada na calçada sob sol quente a pesquisadora desistiu de acompanhar o carroceiro, pois foi vencida pelo cansaço. Naquele dia, o catador nem tirou seu cochilo, pois preferiu fazer companhia à pesquisadora. Volta e meia, nas pequenas pausas, parava para beber alguns goles de cachaça, ou pedia licença para fazer "xixi”, escondido em algum terreno vazio e atrás de algum muro. Quando retornava para puxar a carroça, o catador exalava cheiro de maconha. Disse que não consumia crack, pois era a "pedra da morte". Porém, comentou que muitos conhecidos consumiam diariamente para aumentar a disposição para o trabalho.

A parada foi num ferro-velho, onde foi vendido o material. Sr. João ficava atento para não haver "erro" (roubo) na pesagem dos materiais recicláveis e nos valores que deveria receber. Ficou feliz, pois recebeu $\mathrm{R} \$ 30,00$ - o que significou que a coleta foi boa. Ele pegou o valor de R \$ 15,00 para gastos com alimentação e deixou o restante aos cuidados do dono do ferro-velho. Sr. João disse que não precisava anotar os valores, pois guardava tudo na memória. Costumava pegar o total de dinheiro no final do mês, quando levava para ex-mulher que morava numa favela na Marginal do Tietê. Disse que era para pagar a "pensão" da filha caçula. O catador comentou que havia puxado 600 quilos até aquele momento. Ele iria continuar a coleta por mais sete horas, no mínimo. Era impressionante sua resistência. Os catadores chegavam a caminhar durante 30 quilômetros por dia, puxando carroças pesadas!

Após a jornada de trabalho do Sr. João, foi necessário marcar outro dia e horário para realizar a entrevista. A escolha dos demais entrevistados foi feita de maneira aleatória e o único critério era exercer a ocupação e principalmente aceitar participar das entrevistas. Para não atrapalhar a atividade dos trabalhadores, as pesquisas foram 
realizadas antes das $6 \mathrm{~h}$, ou entre as $21 \mathrm{~h}$ e a $1 \mathrm{~h}$, durante quase dois meses. A pesquisadora encontrava os catadores na rua nos locais onde costumavam dormir, isto é, debaixo dos viadutos e marquises e nas praças, de preferência perto de postos policiais, por motivos de segurança. Reclamavam das algazarras feitas por alguns moradores de rua que passavam a noite bebendo e fumando crack.

Os próprios catadores orientaram a pesquisadora como proceder para ir ao encontro com eles. Foi recomendado vestir-se de maneira simples, isto é, camiseta, calça e jaqueta jeans, calçado velho, prender o cabelo, não usar maquiagem, relógio, jóias, não portar celular e levar pouca quantia em dinheiro. Os papéis para anotação deveriam ser carregados dentro de sacola plástica. Ela deveria estacionar o carro distante do local onde os moradores estivessem aglomerados. Logo que se aproximasse do grupo, deveria perguntar pelo nome do entrevistado. Isso era uma forma de mostrar que a pesquisadora era conhecida por alguém do grupo e garantir que não haveria nenhuma agressão contra ela. Quando o catador não se encontrava no local ou estava alterado por causa da bebida ou drogas, a entrevistadora deixava para voltar outro dia.

Foram poucos os casos em que o catador estava bêbado ou drogado. Parecia que eles se mantinham sóbrios por causa da entrevista. $\mathrm{O}$ entrevistado procurava se afastar do grupo para conversar com a pesquisadora. Pedia para que os colegas não falassem alto, nem fizessem muito barulho e principalmente para evitar o uso de palavrões na frente da "doutora", ou "professora". No início, demonstravam desconfiança em relação às perguntas. Quando se estabelecia uma relação de confiança, contavam sua história de vida. Demonstravam alegria em alguns momentos e em outros ficavam tristes e melancólicos com as lembranças. Quando não queriam falar sobre determinadas questões, preferiam ficar calados, mudar de assunto ou dizer abertamente que se recusavam a responder. 
As entrevistas costumavam durar cerca de uma hora e meia. Muitas vezes, os catadores aproveitavam para desabafar, pedir informações e trocar idéias com a pesquisadora. Nesses casos, as conversas duravam mais tempo. A maioria dos entrevistados foi indicada por pessoa conhecida. Depois do período de pesquisa, foi possível reencontrar alguns catadores no momento de trabalho. Sempre faziam questão de cumprimentar a pesquisadora de maneira amigável e traziam novos dados e informações para este estudo. Os catadores estavam cada vez mais preocupados com a falta de materiais recicláveis e a queda no valor dos produtos. A falta de perspectivas de melhora na situação de vida e trabalho fazia surgir um sentimento impotência na pesquisadora. Era impossível ficar distante e indiferente diante daquela realidade.

Durante a pesquisa com catadores moradores de rua, a pesquisadora soube da existência do Albergue Dom Bosco, situado no Bairro Bom Retiro, através de uma reportagem de revista. Esse albergue era mantido por uma igreja católica e abrigava apenas catadores, ao todo em torno de 40 pessoas. Tinha locais para deixar as carroças e animais. Quando necessário, também era permitida a permanência de esposa, marido e filhos. O horário de saída da instituição era às $6 \mathrm{~h}$ e de entrada, até as $22 \mathrm{~h}$. Depois da autorização da direção do albergue, foi dado início às entrevistas, realizadas antes do início do trabalho, isto é, após o café da manhã, realizado entre $6 \mathrm{~h}$ e $6 \mathrm{~h} 30$ nos bares mais próximos, ou após o retorno dos catadores, a partir das 20 horas.

As entrevistas foram realizadas num local que ficava de frente ao dormitório. As conversas duravam em média uma hora. Não era possível demorar mais tempo, pois os catadores precisavam dormir o mais cedo possível para acordar às 5h. Após levantar, faziam a higiene pessoal e procuravam deixar o espaço organizado e limpo. Os catadores eram obrigados a seguir regras e normas para poder permanecer no albergue durante determinado período. Existia um trabalho de orientação para que os sujeitos 
aprendessem a administrar a renda recebida, poupar dinheiro e, principalmente, sair da condição de moradores de rua. Segundo a assistente social, a minoria conseguia deixar de viver nas ruas definitivamente.

Os trabalhadores eram incentivados pela direção do albergue a participarem de cooperativas e associações de catadores. Alguns aceitaram a proposta e trabalhavam um período do dia na cooperativa e outro na rua, coletando materiais recicláveis. A assistente social percebeu mudança de atitude dos catadores com essa experiência. Demonstravam interesse em participar de cursos e reuniões de discussão e se tornaram mais autônomos e solidários uns com outros. A experiência era positiva ao ponto dos sujeitos planejarem formar uma cooperativa junto ao albergue. $O$ trabalho na cooperativa tinha como objetivo o resgate da dignidade desses trabalhadores, através do trabalho organizado, trabalho coletivo, da melhoria nas condições de vida.

No início, foi difícil a aceitação para participar da pesquisa, tanto pelos catadores moradores de rua, como pelos moradores de albergue, pois todos ficavam extremamente desconfiados. Achavam que a entrevistadora era policial ou fiscal da prefeitura. Entre os catadores, muitos possuíam histórico de ex-presidiário, foragido, drogado ou traficante, ou sentiam-se envergonhados por não saberem se expressar corretamente, entre outros motivos. A abertura para a entrevista vinha com o tempo, depois de muita conversa e explicações sobre os propósitos do estudo. Verificou-se que a indicação de pessoas conhecidas facilitava o contato da pesquisadora com o catador.

Foi adotado um questionário semiestruturado com perguntas abertas e fechadas, abordando aspectos socioeconômicos; condições de trabalho; organização do trabalho; trajetória ocupacional; aspectos subjetivos no trabalho; condições de saúde e doença; acidentes de trabalho; condições de vida; questão trabalhista e previdenciária; e formas de organização dos trabalhadores. Tais tópicos surgiram após a realização de quatro 
entrevistas abertas de longa duração sobre a trajetória de vida e trabalho dos catadores. Foi utilizado gravador com a permissão dos próprios entrevistados na pré-pesquisa.

Num primeiro momento, houve a tentativa de usar o gravador nas demais entrevistas da pesquisa. Devido à resistência de alguns catadores, houve mudança na técnica. As respostas dos entrevistados eram redigidas nos próprios questionários, mantendo-se a preocupação de relatar todas as informações de maneira detalhada e minuciosa e tendo o cuidado, inclusive, de redigir a fala dos trabalhadores do modo mais próximo possível da oralidade.

O sentimento de ser "invisível" se refletia no comportamento dos entrevistados quando demonstravam desconfiança e medo na interação com a pesquisadora, no início da entrevista. Certamente, passavam pela cabeça destes catadores questões como: “O que esta mulher quer comigo... Quem sou eu? Eu não sou nada... sou apenas um trabalhador que vive do e no lixo". Depois de muita conversa e aproximação, os catadores revelavam "gostar da atenção das pessoas" e se sentiam privilegiados por alguém estar interessado no seu trabalho e na sua vida.

O tempo para estes indivíduos era dividido entre "trabalhar, comer, beber e dormir". Nesta perspectiva, a entrevista era um momento singular, em que pela primeira vez eles paravam para pensar em si mesmos. O passado era lembrado de maneira confusa e várias experiências haviam sido apagadas na memória, devido à própria idade, defesas psicológicas e ao consumo de bebidas e drogas. A fala dos entrevistados costumava ser entrecortada por silêncios, lapsos de memória, choros e risadas.

Muitos tinham dificuldade para se expressar, por possuírem um vocabulário reduzido. Nestes casos, procuravam descrever os acontecimentos da forma mais concreta possível, baseando-se em datas e idade, por exemplo. O mais importante é que no final das entrevistas todos diziam ter gostado de "contar sua vida" e ficavam 
surpresos, devido ao tempo de duração da conversa (mais de uma hora) e tantas coisas para dizer. Afirmavam então a importância de serem ouvidos, pois isso era sinal de respeito e reconhecimento enquanto pessoas e indivíduos.

\subsubsection{Experiência na cidade: vendedores ambulantes}

Conforme citado no início desse capítulo, as entrevistas com os vendedores ambulantes na segunda fase da pesquisa foram realizadas por uma estagiária, então estudante universitária. O trabalho de campo durou dois meses, realizado durante os meses de julho e agosto de 2008. Foi utilizado um questionário semiestruturado, com questões abertas e fechadas. Além disso, a maior parte das entrevistas foi gravada. Esse procedimento foi adotado para que não fosse perdida nenhuma informação. Os vinte entrevistados, sendo 12 homens e 8 mulheres, trabalhavam nos bairros da região norte da cidade de São Paulo (Tucuruvi, Jaçanã e Santana).

Os camelôs foram escolhidos para entrevista de duas maneiras: abordagem direta, ou indicação de pessoas conhecidas. Eles foram entrevistados em seus locais de trabalho, nos horários de menor movimento, ou em suas residências. A maioria não demonstrou resistência em participar da pesquisa e não criticou o uso do gravador. As respostas negativas tinham a ver com a falta de tempo, não querer falar de sua própria vida e medo da fiscalização, entre outros motivos. As entrevistas duravam entre uma hora e uma hora e meia. Segundo a estagiária, alguns entrevistados queriam preencher o questionário, discutiam o porquê de determinadas perguntas, queriam falar de outros assuntos - fato que fazia com que as conversas fossem mais demoradas. 
A estagiária procurou abordar principalmente os comerciantes de produtos alimentícios, como vendedores de cachorro-quente, churrasquinho, minipizza, doces, salgados, sorvetes e frutas, entre outros. Esses camelôs demonstraram-se mais acessíveis que outros abordados. Alguns tinham medo de participar do estudo por estar vendendo produtos piratas, importados e sem nota fiscal, por exemplo. $\mathrm{O}$ fato da pesquisa ser acadêmica e da entrevistadora ser estudante universitária facilitou a aceitação dos trabalhadores em participar do estudo. A maior dificuldade foi conseguir entrevistá-los enquanto estavam trabalhando, pois precisavam preparar os alimentos nos intervalos e dar atenção aos clientes no horário de pico (das $7 \mathrm{~h}$ às $9 \mathrm{~h}$; das $12 \mathrm{~h}$ às $15 \mathrm{~h}$; e das $17 \mathrm{~h}$ às $20 \mathrm{~h})$.

Durante a realização das entrevistas, a estagiária não passou por qualquer situação de "rapa"224. Os camelôs entrevistados não permaneciam agrupados num mesmo local. Costumavam ficar de frente aos hospitais, da Unidade Básica de Saúde mais próxima, de escolas e pontos de ônibus, entre outros locais. Os pontos de venda dos vendedores ambulantes, de meu estudo, estavam situados em locais distantes dos grandes centros comerciais em que a fiscalização da Guarda Municipal era mais ostensiva. Foram entrevistados alguns trabalhadores que vendiam produtos de porta em porta, ou nas casas dos clientes. Todos os questionários estavam devidamente preenchidos. As respostas das perguntas abertas foram obtidas com maiores detalhes nas gravações. A pesquisadora procurou transcrever a fala dos trabalhadores, no caso das questões abertas. Alguns comentários realizados pelos entrevistados fora do roteiro da pesquisa foram importantes para a análise e compreensão dos dados em geral.

A escolha de pesquisar os vendedores ambulantes decorre, em primeiro lugar, do fato de que o comércio é considerado uma das principais atividades desenvolvidas pelos

224 O "rapa" é a ação de apreensão de mercadorias vendidas pelos vendedores ambulantes pelos fiscais da Prefeitura. Quando os vendedores demonstram resistência para entregar as mercadorias é comum ocorrer atos de violência por parte da Guarda Municipal. 
trabalhadores na economia informal urbana (MELO et alii) ${ }^{225}$. No Brasil, na estrutura do setor de serviços ${ }^{226}$, o comércio se apresenta como extremamente relevante, respondendo por cerca de $22,53 \%$ da ocupação do setor serviços e por $6,3 \%$ da geração do PIB em 1995. Além do mais, essa atividade gerou cerca de $26 \%$ dos postos de trabalho na economia nacional, numa comparação entre 1985 e $1995^{227}$.

Considerando-se a importância do comércio na oferta de postos de trabalho, deve ser ressaltado o significado do comércio ambulante ${ }^{228}$, que aumentou expressivamente seu peso no interior do setor. É importante esclarecer que $68 \%$ dos postos de trabalho no comércio são originários do comércio varejista e atacadista, mas $21 \%$ derivam do comércio ambulante, numa tendência que se manifestou mais fortemente nos anos 90 em todo o país 229.

$\mathrm{MELO}^{230}$, ao analisar a ocupação de ambulantes, concluiu que no setor de serviços são as atividades de comércio, de hospedagem e de alimentação que concentram o maior contingente de microempresários informais e que, no corte de conta-própria, são as atividades de manicure/cabeleireiros e o comércio ambulante as mais significativas para os trabalhadores por conta-própria ${ }^{231}$. Nesse mesmo estudo, a autora observa que em 1996, 88\% da mão-de-obra na informalidade no Brasil eram compostos por trabalhadores por conta-própria, o que nos possibilita pensar que os pequenos negócios não comportam nada além do próprio trabalhador.

225 MELO, Hildete Pereira de; TELES, Jorge Luiz Teles (2000). Serviços e Informalidade: o

comércio ambulante no Rio de Janeiro. Texto para Discussão n ${ }^{\circ} 773$, Instituto de Pesquisa Econômica Aplicada (IPEA), Rio de Janeiro, dezembro. 226 O setor de serviços teve um crescimento espetacular na geração de empregos e de produto na economia mundial e nacional. No Brasil, na década de 90 , o setor de serviços foi o que mais expandiu o emprego, tanto em termos absolutos, como em relação ao seu próprio tamanho. Ademais, constitui a atividade econômica que mais contribuiu para a geração de postos de trabalho no país, com um crescimento sistemático de sua participação no emprego urbano. In: MELO, H. P.; ROCHA, F.; FERRAZ, G.; Di SABBATO, A; DWECK, Ruth (1998, p. 36). O Setor de Serviços no Brasil: uma visão global - 1985/95. A Economia Brasileira em Perspectiva 1998, Rio de Janeiro: IPEA, v. 2.

227 MELO, Hildete Pereira de; TELES, Jorge Luiz (2000). Texto para Discussão n 549, Instituto de Pesquisa Econômica Aplicada (IPEA), Rio de Janeiro. 228 ambulante é definido como aquele realizado na rua e pelos vendedores de porta em porta.

229 MELO, H., ROCHA, F., FERRAZ, G., DI SABBATO, A., DWECK, R. (1998). O setor de serviços no Brasil: uma visão global - 1985/1995. A Economia Brasileira em Perspectiva 1998, Rio de Janeiro: IPEA, v. 2.

230 MELO, H. P. de (1999). Os Serviços e a Economia Informal Urbana - notas preliminares. Rio de Janeiro, mimeo.

231 A base de dados deste trabalho é a PNAD/IBGE. 
A evolução dos trabalhadores por conta-própria no período de 1991 a 1998 apresentou a maior taxa de crescimento, principalmente nas regiões metropolitanas do Rio de Janeiro e de São Paulo. A expansão do comércio ambulante demonstrou que o impacto desse tipo de atividade informal na economia das regiões metropolitanas está aumentando, ou seja, os dados reforçam a hipótese de um empobrecimento do mercado de trabalho e da precarização das relações de trabalho nas grandes regiões metropolitanas.

No Rio de Janeiro, praticamente $70 \%$ dos trabalhadores estão alocados no setor de serviços, que é caracterizado por atividades econômicas atrasadas e de baixa qualificação, com maiores graus de informalidade. No estudo de MELO et alli ${ }^{232}$ sobre comércio ambulante na capital fluminense na década de 90, percebeu-se que essa atividade é a preferida da mão-de-obra masculina, mobilizando cerca de $60 \%$ dos informais.

Os autores destacam que as atividades dos ambulantes que trabalham nas ruas envolvem riscos, seja nas disputas pela posse dos pontos, pelo perigo de assaltos, ou pela perseguição por parte dos fiscais da prefeitura, por exemplo. Tais problemas são mais frequentes nas regiões centrais das cidades e, mais ainda, nas ruas com maior movimento de pedestres, consideradas bons pontos de venda. Com essas características, portanto, é de se esperar uma participação maior de homens nessa atividade, conforme os dados citados.

Pode-se considerar que a rua é lugar dos homens trabalharem. Já entre vendedores "porta a porta”, provavelmente será encontrada uma parcela considerável de mulheres e que vem aumentando significativamente ao longo dos últimos anos. Entre as

232 MELO, Hildete Pereira de; TELES, Jorge Luiz (2000). Serviços e Informalidade: o comércio ambulante no Rio de Janeiro. Texto para Discussão n ${ }^{\circ} 773$, Instituto de Pesquisa Aplicada (IPEA), Rio de Janeiro, dezembro. 
vendedoras "porta a porta", podem ser citadas em especial as representantes de cosméticos e produtos de beleza, entre outros artigos diversos.

\subsection{Metodologia}

\subsubsection{Levantamento de dados secundários}

Os dados estatísticos oficiais foram obtidos junto às bases de dados do Serviço Brasileiro de Apoio às Micro e Pequenas Empresas (SEBRAE); do Instituto Brasileiro de Geografia e Estatística (IBGE); do Instituto de Pesquisa Econômicas Aplicadas (IPEA); do Ministério do Trabalho e Emprego (MTE); e da Organização Internacional do Trabalho (OIT). Os artigos, as publicações, as teses de doutorado, as dissertações de mestrado e as informações científicas consultadas foram obtidas a partir de um trabalho de pesquisa em diversos bancos de dados online, na área das Ciências Sociais, Economia e Saúde Pública, além dos acervos de universidades e órgãos governamentais nacionais e estrangeiros. Este estudo procurou se basear nos principais autores, brasileiros e internacionais, que discutem a questão do trabalho e da economia informal no Brasil e outros países em desenvolvimento. 


\subsubsection{Estudo exploratório (pré-teste da pesquisa)}

A primeira fase do presente estudo consistiu numa pesquisa de campo exploratória, iniciada em 2006. Em relação à primeira etapa, foram realizadas algumas entrevistas semiestruturadas com membros do Movimento Unido dos Camelôs (MUCA), da Central Única dos Trabalhadores do Rio de Janeiro e com os vendedores ambulantes e camelôs ${ }^{233}$ na região central do Rio de Janeiro. O contato com os camelôs ou vendedores ambulantes ocorreu com o apoio do Movimento Unido dos Camelôs.

Em São Paulo, foram realizadas entrevistas semiestruturadas com o presidente do Sindicato dos Trabalhadores na Economia Informal (SINTEIN), órgão vinculado à Central Única dos Trabalhadores (CUT) do Estado. Participamos do $1^{\circ}$ Seminário sobre Trabalho Informal em São Paulo, promovido pela CUT de São Paulo. Nessa perspectiva, foram realizadas entrevistas com camelôs e vendedores ambulantes na região central da capital paulista, na Rua 25 de Março.

Participamos de seminários sobre a ocupação da cidade de São Paulo; encontros com trabalhadores informais, cooperativas e entidades populares; encontros nacionais de economia solidária; congressos, conferências e simpósios nas áreas de Ciências Sociais, Economia e Previdência Social, sempre buscando enfocar a questão do trabalho informal.

A pesquisa de observação teve papel fundamental para o conhecimento da realidade dos vendedores ambulantes e camelôs, suas condições de vida e trabalho. Além dos camelôs e vendedores ambulantes, procuramos entrevistar e observar informalmente as atividades de trabalho na rua de outras categorias, como carroceiros; 
catadores de materiais recicláveis; "flanelinhas",234; sorveteiros; limpadores de vidros de carros; distribuidores de folhetos, os artistas que vivem da rua como os malabaristas nos semáforos; músicos; "homens-sanduíche"235; "homens-placa" ou "plaqueiros"; e motoboys, por exemplo. Tentamos colecionar a maior quantidade de elementos possível para obter uma visão ampla do trabalho informal e compreender as características em comum entre as diversas atividades observadas.

Foram realizadas algumas pesquisas exploratórias e entrevistas com vendedores ambulantes e camelôs, bem como observações de seu trabalho em vários Estados do Brasil - Pernambuco, Bahia, Santa Catarina e Rio Grande do Sul, além do Rio de Janeiro e São Paulo - e no exterior - Argentina (Buenos Aires), Uruguai (Montevidéu) e Chile (Santiago do Chile). É importante esclarecer que não houve o intuito de realizar estudos comparativos e que as observações e conversas informais contribuíram para a compreensão do trabalho informal como um fenômeno internacional.

A pesquisadora teve a experiência de trabalhar como vendedora ambulante na região central da cidade do Rio de Janeiro. Tentou vender artesanatos, como bijuterias, brincos e pulseiras que ficavam dispostos sobre um tabuleiro. A maior dificuldade foi atender o público nos horários de maior movimento. Tinha que dar atenção a cada cliente, controlar o dinheiro e os produtos. Os donos da barraca eram um casal. $\mathrm{O}$ marido era químico e ex-proprietário de uma microempresa e a esposa, ex-bancária e dona-de-casa. No período da pesquisa, o marido estava terminando a segunda faculdade, administração de empresas, e esperava entrar em algum concurso público. Esse foi um

$234 \mathrm{O}$ "flanelinha" significa o cuidador de carros estacionados nas vias públicas que recebem gorjeta ou valor de tarifa estabelecida na região da cidade. 235 Os "homens-sanduíche", "homens-placa" ou "plaqueiros" são homens - raras vezes mulheres- que andam pelos centros comerciais de diversas cidades carregando, penduradas aos ombros, duas placas de compensado, uma voltada para a frente e outra às suas costas. Nessas placas são estampados anúncios de diversos produtos e serviços, como a compra e venda de ouro, tíquetes-refeição ou bilhetes de metrô. Em geral, são desempregados ou aposentados que procuram complementar sua renda utilizando o corpo como veículo de comunicação. SANCHES, Rodrigo (2007). Do homem-placa ao pixman: o processo iconográfico na relação da imagem, mídia e corpo. Comunicação e Mercado, volume 7; nº 2; $2^{\circ}$ sem, pp. 135. 
caso raro em que os sujeitos com nível de escolaridade maior eram desempregados e estavam desenvolvendo uma atividade informal.

Tanto na Rua 25 de Março, quanto na Voluntários da Pátria, em São Paulo, e na Rua Uruguaiana, no Rio de Janeiro, a pesquisadora teve a oportunidade de estar presente no momento do "rapa", isto é, quando a fiscalização aprendia mercadorias dos camelôs. Em uma dessas situações a entrevistadora foi abordada pela Guarda Municipal e teve a máquina fotográfica digital e caderno de anotações apreendidos. Os guardas argumentaram que não poderia filmar a correria, o tumulto, as agressões contra os trabalhadores no momento de apreensão. Disseram que os camelôs eram "um bando de bandidos e traficantes" que não mereciam ser estudados. O mais impressionante que após os guardas irem embora, o comércio voltava à situação normal.

O interesse pelo trabalho informal e a desigualdade social nas cidades ampliouse para a situação de informalidade no campo. Nessa perspectiva, a pesquisadora procurou estudar as condições de vida e trabalho dos vendedores ambulantes, catadores de material reciclável, colhedores de laranja e pescadores de lagosta. Era importante destacar que o fato da pesquisadora estar vinculada a uma instituição de pesquisa do Ministério do Trabalho e Emprego (MTE) facilitou o desenvolvimento do estudo. Esclareço que os dados analisados na tese estavam relacionados aos projetos de pesquisa do Serviço de Sociologia e Psicologia da Fundação Jorge Duprat de Figueiredo de Medicina e Segurança no Trabalho (FUNDACENTRO/MTE). 


\subsubsection{Pesquisa qualitativa: trajetórias sociais e profissionais}

Na realização do presente estudo foi utilizado, principalmente, o método de pesquisa qualitativo. Apesar da amostra ser aleatória e não representar estatisticamente a população dos trabalhadores informais no país nas ocupações de vendedor ambulante, catador de material reciclável e colhedor de laranja, procuramos obter dados quantitativos para efeitos de sistematização e análise das informações junto aos dados qualitativos. O questionário foi semiestruturado com questões abertas e fechadas. Além disso, foram realizadas entrevistas de longa duração com trabalhadores, familiares, representantes de instituições sindicais, movimentos sociais e órgãos do governo.

As principais referências bibliográficas para compreender as trajetórias sociais e profissionais foram as obras de Claude Dubar e Didier Demazière ${ }^{236}$; e Pierre Bourdieu $^{237}$. Segundo Dubar ${ }^{238}$, as pesquisas que têm como base o processo biográfico dos indivíduos, ou seja, suas trajetórias sociais, devem considerar dois aspectos: o primeiro deles é a "trajetória objetiva", que pode ser entendida como a sequência das posições sociais que o indivíduo ocupa durante a vida. O outro é a "trajetória subjetiva", trazida nos relatos biográficos através de histórias pessoais e que apresentam as visões que os indivíduos têm de si e do mundo.

DUBAR esclareceu que as "trajetórias objetivas" têm a ver com as experiências institucionais dos sujeitos nos âmbitos escolar, profissional, cultural, institucional, etc. Segundo o autor, as posições sociais devem ser medidas por categorias estatísticas e condensadas numa tendência geral. Já a "trajetória subjetiva" expressa em diversos

236 DEMAZIÈRE, D.; DUBAR, C. (2006) . Trajetórias profissionais e formas identitárias: uma teorização. In: Guimarães, N. A.; Hirata, H. (orgs.). Desemprego: trajetórias, identidades, mobilizações. São Paulo: Editora SENAC, Série Trabalho e Sociedade. 237 ORTIZ, Renato (org.). Pierre Bourdieu: sociologia. São Paulo: Ática, Grandes cientistas sociais. 238 DUBAR, Claude (1998). Trajetórias sociais e formas identitárias: alguns esclarecimentos conceituais e metodológicos. Educação \& Sociedade, volume 19, n. 62, Campinas, Abril. p. 1 
relatos biográficos as categorias inerentes ao sujeito, a sua história pessoal, que remete a "mundos sociais". O agrupamento dessas categorias possibilita a construção de formas identitárias heterogêneas. Dessa maneira é importante apreender identidades sociais como processos ao mesmo tempo biográficos e institucionais.

Para DEMAZIÈRE e DUBAR “um esquema de interpretação determinista, que privilegiasse o impacto da situação sobre as atitudes e comportamentos, seria manifestamente inadequado". Os autores argumentaram que "todos estavam na mesma situação, mas não reagiam do mesmo modo" e que:

apenas um enfoque compreensivo permitiria dar conta dessas diferenças, irredutíveis a posições em uma escala única. (...) Posições diferentes sobre o trabalho e o emprego emergiam da análise das entrevistas recolhidas e coexistiam no seio das mesmas categorias de assalariados (operários da produção ou da manutenção, empregados de escritório, técnico, etc.) ou de desempregados (homens e mulheres, jovens inexperientes, adultos no final da vida ativa, etc. $)^{239}$.

Para DUBAR, os pontos de vista da trajetória objetiva e subjetiva interferem nos vários usos da noção de identidade. $\mathrm{O}$ autor defende que seja dada importância às categorias institucionais, determinando posições objetivas, e às categorias de linguagem utilizadas por indivíduos em situação de entrevista de pesquisa. Trata-se de levantar as categorias estruturantes a partir da análise de relato. As regras de disjunção e conjunção possibilitam a produção de sentido. Nesse caso, o autor defende os aspectos subjetivos da biografia, sem cair no essencialismo ou subjetivismo que diz respeito ao tipo de 
personalidade ou formas estáveis de percurso, comum nas abordagens biográficas individuais $^{240}$. Segundo DEMAZIÈRE \& DUBAR, a dimensão biográfica é definida

a partir da relação temporal, ou seja, dos modos de contar seu próprio percurso profissional, de ligar a narração de seu passado às suas antecipações de futuro. (...). Para os assalariados, as trajetórias podiam tanto se inscrever em carreiras profissionais predefinidas por referência aos modos de gestão da empresa ou às regras definidoras dos grupos e categorias profissionais, quanto marcar distâncias significativas em relação a esses modelos de carreira. Para os desempregados, as reivindicações individuais podiam ir ao encontro de modelos institucionais estabelecidos, cuja referência é a figura normativa do bom desempregado, ou, ao contrário, situar-se a distância desses modelos, em uma busca identitária dependente mais de si mesmo que de outrem ${ }^{241}$.

Por outro lado, DUBAR critica a análise "objetivista" das trajetórias na medida em que não se leva em conta o sentido subjetivo que os indivíduos atribuem ao próprio percurso. Trata-se, também, de uma análise necessariamente redutora, uma vez que a posição, num dado momento, é medida apenas em uma escala. É a relação entre as posições sucessivas que importa no modelo e não cada posição social isolada numa escala. DUBAR comenta que as "trajetórias objetivas" condicionam os percursos individuais. Já as trajetórias subjetivas almejam compreender os discursos biográficos como "processos identitários individuais", por meio dos quais as crenças e as práticas dos membros de uma sociedade contribuem para inventar novas categorias, modificar as antigas e reconfigurar permanentemente os próprios "quadros de socialização".

240 DUBAR, Claude (1998). Trajetórias sociais e formas identitárias: alguns esclarecimentos conceituais e metodológicos. Educação \& Sociedade, volume 19, n. 62, Campinas, Abril. p. 2. 241 DEMAZIÈRE, D.; DUBAR, C. (2006) . Trajetórias profissionais e formas identitárias: uma teorização. In: Guimarães, Nadya Araujo; Hirata, Helena (orgs.). Desemprego: trajetórias, identidades, mobilizações. São Paulo: Editora SENAC, Série Trabalho e Sociedade, p. 171. 
Para DUBAR, a análise das trajetórias sociais possibilita verificar as formas identitárias profissionais, centradas nas relações entre o mundo da formação e o mundo do trabalho e emprego. As identidades profissionais podem ser consideradas identidades sociais na medida em que, num dado sistema social, as instituições, a posição social, a riqueza, o status e/ou prestígio dependem do nível de formação, da situação de emprego e das posições no mundo do trabalho. Segundo o autor, "nas sociedades contemporâneas, a trilogia formação/emprego/trabalho parece ser a mais estruturante dos 'espaços-tempos' individuais e, portanto, da maneira segundo a qual as pessoas especialmente os homens - 'narram sua vida' e categorizam suas situações sucessivas quando assim solicitadas para fins de pesquisa".

Ao se pesquisar trajetórias sociais dos trabalhadores em minha pesquisa, era preciso considerar a interrelação entre história pessoal e condição social na qual estavam inscritos os sujeitos. Somente assim, seria possível compreender as trajetórias profissionais que determinaram as ocupações atuais. Nessa perspectiva, acreditou-se que a realidade social é a base tanto para possíveis projetos pessoais, quanto para sua viabilidade ou não. As posições ocupadas pelos indivíduos ao longo de sua trajetória profissional o colocam frente a séries de determinações, sendo essas decisivas na construção de possibilidades de inserção no mundo do trabalho e nas compreensões de si mesmo. Sendo assim, tornou-se importante considerar tais posições para a compreensão das diversas biografias e identidades profissionais.

Para DUBAR, a idéia de identidades sociais estava relacionada às várias posições sociais dos indivíduos na suas trajetórias. Sendo assim, as formas identitárias, longe serem um conceito estático e definitivo, estão relacionadas a um processo de construção de identidade que se dá a partir de mudanças e mobilidades ascendentes ou descendentes na escala social, seja na esfera do trabalho, família, educação ou lazer, 
entre outras, durante as trajetórias. No meu estudo, procuramos verificar as identidades dos trabalhadores informais na esfera de trabalho e na esfera da família, considerando que estes espaços de socialização permitiriam aos indivíduos assumir papéis sociais, e através disso articular suas vivências.

A trajetória do trabalhador informal, categoria que inclui os trabalhadores por conta-própria e os assalariados sem carteira de trabalho, diz respeito aos processos de elaboração de identidades, uma vez que essas identidades são construções sociais e implicam a interação entre trajetória individual e os vínculos estabelecidos pela atuação em diversas esferas. Escolhi a articulação, principalmente, entre a esfera profissional e familiar, na medida em que os entrevistados, em sua maioria, podem ser considerados desempregados de longa duração que realizam atividades informais ou "bicos". A problemática do desemprego e a luta pela sobrevivência atingem diretamente as famílias dos trabalhadores entrevistados.

DUBAR determinou que as configurações identitárias são resultantes de uma dupla transação entre, de um lado, o indivíduo e as instituições (por exemplo, a empresa em que trabalha/dimensão relacional) e, de outro, o indivíduo confrontando com as mudanças, seu passado e sua trajetória pessoal (dimensão biográfica). Nesse sentido, ao longo de minha pesquisa, no intuito de dar sentido a uma interpretação das práticas sociais, procurei trabalhar com as dimensões citadas acima, relacional e biográfica, isto é, interpretar as práticas sociais dos sujeitos em sua relação social nas diversas instituições e consigo mesmo. Por meio da compreensão das práticas sociais dos trabalhadores nas trajetórias profissional e familiar, ou seja, das narrativas que procuram dar sentidos a essas trajetórias, foram elaboradas várias entrevistas que possibilitaram definir diversas identidades sociais. 
Em BOURDIEU, cada grande tipo de trajetória social está associado a um "habitus de classe". O conceito de habitus surge da necessidade empírica de apreender as relações de afinidades entre o comportamento dos agentes e as estruturas e condicionamentos sociais. Para BOURDIEU, habitus deve ser compreendido como:

[...] um sistema de disposições duráveis e transponíveis que, integrando todas as experiências passadas, funciona a cada momento como uma matriz de percepções, de apreciações e de ações - e torna possível a realização de tarefas infinitamente diferenciadas, graças às transferências analógicas de esquemas, que permitem resolver os problemas da mesma forma, e às correções incessantes dos resultados obtidos, dialeticamente produzidas por esses resultados $[\ldots]^{242}$.

Nessa perspectiva, habitus foi concebido como princípio mediador, princípio de correspondência entre as práticas individuais e as condições sociais de existência. Foi nas situações de desajustamento entre as mais diversas práticas individuais e as condições sociais de existência percebidas que o conceito se tornou explícito. A construção da teoria do habitus está relacionada à conciliação de duas leituras do social segundo BOURDIEU, o mundo social é objeto de três modos de conhecimento teórico, citados a seguir:

o fenomenológico [...] que explicita a verdade da experiência primeira do mudo social, isto é, a relação de familiaridade com o meio familiar, apreensão do mundo social como mundo natural e evidente, sobre o qual, por definição, não se pensa, e que exclui a questão de suas próprias condições de possibilidades. $\mathrm{O}$ conhecimento que podemos chamar de objetivista ( de que a hermenêutica estruturalista é um

242 BOURDIEU, P. (1983). Esboço de uma teoria prática. In: ORTIZ, Renato (org.). Pierre Bourdieu: Sociologia. São Paulo: Ática, Grandes cientistas sociais; 39 p. 65 . 
caso particular) constrói relações objetivas ( isto é, econômicas ou lingüísticas), que estruturam as práticas e as representações das práticas, ao preço de uma ruptura com esse conhecimento primeiro e, portanto, com os pressupostos tacitamente assumidos que conferem ao mundo social seu caráter de evidência e de natural [...] Enfim, o conhecimento que podemos chamar de praxiológico tem como objeto não somente o sistema das relações objetivas que o modo de conhecimento objetivista constrói, mas também as relações dialéticas entre essas estruturas e as disposições estruturadas nas quais elas se atualizam e que tendem a reproduzi-las; isto é, o duplo processo de interiorização da exterioridade e de exteriorização da interioridade $[\ldots] .{ }^{243}$

O conceito de habitus procurou conciliar a oposição aparente entre a realidade exterior e as realidades individuais. Foi capaz de expressar o diálogo, a troca constante e recíproca entre o mundo objetivo e o mundo subjetivo das individualidades. Dessa maneira, habitus foi concebido como um sistema de esquemas individuais, socialmente constituído de disposições estruturadas (no social) e estruturantes (nas mentes), adquirido nas e pelas experiências práticas (em condições sociais específicas de existência), constantemente orientadas para funções e ações do agir cotidiano.

Nessa perspectiva, a relação entre indivíduo e sociedade com base na categoria habitus implica afirmar que o individual, o pessoal e o subjetivo são ao mesmo tempo social e coletivamente orientados. Dessa maneira, o habitus deve ser entendido como um conjunto de apropriações e ações postas em prática, tendo em vista que as conjunturas de um campo o estimulam. A teoria praxiológica procurou fugir dos determinismos das práticas ao pressupor uma relação dialética entre sujeito e sociedade e ainda uma relação entre habitus e estrutura de um campo, socialmente determinado.

243 BOURDIEU, P. (1983). Esboço de uma teoria prática. In: ORTIZ, Renato (org.). Pierre Bourdieu: Sociologia. São Paulo: Ática, Grandes cientistas sociais; 39 , pp. 46-47. 
Sendo assim, para Bourdieu, a maior parte das ações dos agentes sociais é produto de um encontro entre um habitus e um campo (conjuntura). Assim, as estratégias surgem como ações práticas inspiradas pelos estímulos de uma determinada situação histórica.

O conceito de habitus procurou recuperar a noção ativa dos sujeitos como produtos da história de todo o campo social e de experiências acumuladas no curso de uma trajetória individual. Os habitus individuais, produtos da socialização, seriam constituídos em condições sociais específicas, por diferentes sistemas de disposições, produzidas em condicionamentos e trajetórias diferentes, em espaços distintos, como a família, a escola e o trabalho, entre outros.

Segundo BOURDIEU, as experiências se integram na unidade de uma biografia sistemática que se organiza a partir da situação originária de classe, experimentada num tipo determinado de estrutura familiar. Desde que a história do indivíduo nunca é mais que certa especificação da história coletiva de seu grupo ou de sua classe, podemos ver nos sistemas de disposições individuais variantes estruturais do habitus de grupo ou de classe sistematicamente organizadas nas próprias diferenças que as separam e onde se exprimem as diferenças entre as trajetórias e as posições dentro ou fora de classe. $\mathrm{O}$ estilo "pessoal", isto é, essa marca particular que carregam todos os produtos de um mesmo habitus, práticas ou obras, não é senão um desvio, ele próprio regulado e "as vezes mesmo codificado, em relação ao estilo próprio a uma época ou a uma classe ${ }^{244,}$.

Podemos considerar que o habitus é um sistema de disposição, não apenas resultado da sedimentação de uma vivência nas instituições sociais tradicionais, mas um sistema em construção, em constante mutação e, portanto, adaptável aos inúmeros estímulos. Além disso, habitus é considerado como trajetória que possibilita a mediação do passado e do presente, como processo histórico e expressão de uma identidade social

244 BOURDIEU, P. (1983). Esboço de uma teoria prática. In: ORTIZ, Renato (org.). Pierre Bourdieu: Sociologia. São Paulo: Ática, Grandes cientistas sociais; 39 , pp. $80-81$ 
em construção. Nessa perspectiva, meu estudo procurou analisar as diversas trajetórias de trabalhadores que desenvolvem atividades informais. Procurou-se compreender as práticas sociais dos indivíduos nos espaços do trabalho e da família.

Em minha pesquisa, na tentativa de compreender as trajetórias sociais dos trabalhadores, encontrei alguns problemas relacionados à prática e teoria; isto é, a questão de método e técnicas de pesquisa, ou melhor, as dificuldades encontradas na interação entre a pesquisadora e o entrevistado ou entrevistada. BOURDIEU ${ }^{245}$ questionou a fidelidade a velhos princípios metodológicos que "eram freqüentemente decorrentes, como ideal da padronização dos procedimentos, de imitar os sinais exteriores mais reconhecidos do rigor das disciplinas científicas". O autor coloca em dúvida os seguintes aspectos: se tudo que acontecia durante a pesquisa fosse levado em consideração; se os pesquisadores sabiam respeitar seu objeto e estavam atentos "às sutilezas quase infinitas das estratégias que os agentes sociais desenvolviam na conduta comum de sua existência", a relação de pesquisa que tem por fim o mero conhecimento continua, apesar de tudo, como uma relação social que exerce efeitos sobre os resultados obtidos.

Para o autor, "mesmo que a interrogação científica excluiu por definição a intenção de exercer qualquer forma de violência simbólica capaz de afetar as respostas; aconteceu, entretanto, que nesses assuntos não se podia confiar somente na boa vontade, porque todo tipo de distorções estavam inscritas na própria estrutura da relação de pesquisa"246. Segundo BOURDIEU, essas "distorções deviam ser reconhecidas e 
dominadas; e isso na própria realização de uma prática que podia ser refletida e metódica" ${ }^{, 247}$.

Para BOURDIEU, apenas a "reflexividade", que era sinônimo de método, permitia perceber e controlar, no campo, na própria condução da entrevista, os efeitos da estrutura social na qual ela se realiza. Nessa perspectiva, era "importante fazer uso reflexivo dos conhecimentos adquiridos da ciência social para controlar os feitos da própria pesquisa e começar a interrogação já dominando os efeitos inevitáveis das perguntas". Sendo assim, "a ciência que realizava uma construção o fez se esforçando para conhecer e dominar o mais completamente possível seus atos, inevitáveis, de construção e os efeitos que eles produziam também inevitavelmente"248.

No decorrer do trabalho de campo, pude perceber problemas na comunicação com os trabalhadores. O primeiro tinha a ver com a linguagem utilizada, na medida em que os entrevistados e a entrevistadora pertenciam a campos simbólicos distintos. Nesse caso quando os sujeitos não entendiam, diziam: "não entendi. O que você está querendo saber mesmo?”; “Ai, não sei direito. Sou ruim de lembrar das coisas”; "minha cabeça é ruim"; "não sou bom em números”, por exemplo. Eles mesmos se culpavam por não saberem o que estava sendo perguntado, ou não terem resposta. Muitas vezes a pergunta precisava ser reformulada de outra maneira, ou com palavras diferentes. Depois de algumas conversas, foi possível aprender certas expressões, palavras, "gírias" construídas pelo grupo. Isso de certa forma facilitava a interação social.

O segundo problema era decorrente de determinadas perguntas que causavam certo constrangimento ao trabalhador. Por exemplo, quando se pedia que falassem sobre seus empregos ou trabalhos, os motivos de saída, os valores dos rendimentos. Outras questões invasivas eram sobre as doenças, os acidentes, o processo de recuperação, o 
consumo de medicamentos, bebidas e drogas ilícitas, entre outros temas. Nesses casos, os entrevistados costumavam responder por meio do silêncio, de uma expressão facial de desgosto. Falavam pouco, mudavam de assunto, ou simplesmente ressaltavam que não queriam falar sobre aquela questão.

Por mais que se tentasse obter o máximo de informações, a resposta nunca era completa. Existia um filtro no que era dito pelos entrevistados. Além disso, a compreensão da pesquisadora para o discurso dos trabalhadores também era limitada, à medida que possuíam linguagens e pertenciam a campos simbólicos diferentes. Dessa maneira, BOURDIEU destacou a importância de "dominar os efeitos" isto é, "reduzir no máximo a violência simbólica que se pode exercer através do capital cultural”. Era necessário instaurar "uma relação de escuta ativa e metódica, tão afastada da pura nãointervenção da entrevista não dirigida, quanto do dirigismo do questionário”. Segundo o autor, “essa postura associa a disponibilidade total em relação à pessoa interrogada, a submissão à singularidade de sua história particular, que pode conduzir (...) a adotar sua linguagem e a entrar em seus pontos de vistas, em seus sentimentos, em seus pensamentos, com a construção metódica (...) do conhecimento das condições

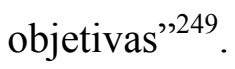

Para BOURDIEU, o sociólogo podia obter do pesquisado declarações na medida em que ele "se sentia legitimado a ser o que ele era, se ela sabia se manifestar, pelo tom e especialmente pelo conteúdo de suas perguntas as quais sem fingir anular a distância social que o separava de si, ele era capaz de se colocar em seu lugar (do pesquisado) em pensamento". O autor comentou que "tentar situar-se em pensamento no lugar que o pesquisado ocupava no espaço social para (o necessitar) a partir desse ponto e para

249 BOURDIEU, P. (2003). Compreender. In: BOURDIEU, P; com contribuições de A. Accardo et. al. A Miséria do mundo. Petrópolis, Rio de Janeiro: Vozes, p. 695 . 
decidir-se de alguma maneira por ele (...) era dar-se uma compreensão (...) fundada no domínio (teórico e prático) das condições sociais das quais ele era produto" 250 .

Foi possível observar no meu estudo que os pesquisados aproveitavam a situação como uma ocasião excepcional que lhes era oferecida para testemunhar, se fazer ouvir, levar sua experiência da esfera privada para a esfera pública; uma ocasião também, segundo BOURDIEU, para se "explicar", isto é, "construir seu próprio ponto de vista sobre eles mesmos e sobre o mundo, e manifestar o ponto, no interior desse mundo, a partir do qual eles vêem a si mesmos e o mundo, e se tornavam compreensíveis, justificados, para eles mesmos em primeiro lugar"251.

Na realidade, os pesquisados, longe de serem simples instrumentos nas mãos do pesquisador, "conduzem de alguma maneira a entrevista e a densidade e intensidade de seu discurso" como se fosse numa "auto-análise provocada e acompanhada" em que realizam um trabalho de explicitação e enunciam, "às vezes com uma extraordinária intensidade expressiva, experiências e reflexões há muito reservadas ou reprimidas". Contra a ilusão que consistia em procurar a neutralidade da anulação do observador, para BOURDIEU só era espontâneo o que era construído, mas por uma "construção realista",252.

250 Idem, p. 704

251 BOURDIEU, P. (2003). Compreender. In: BOURDIEU, P; com contribuições de A. Accardo et. al. A Miséria do mundo. Petrópolis, Rio de Janeiro: Vozes, p. 705 . 


\section{CAPÍTULO 4: TRAJETÓRIAS SOCIAIS DE TRABALHADORES DESEMPREGADOS E INFORMAIS}

O presente capítulo apresenta os resultados encontrados na pesquisa de campo relatada no capítulo 3. A análise dos dados foi realizada a partir de referencial teórico referente aos temas em discussão. O subitem 4.1 discute as trajetórias ocupacionais e de vida de trabalhadores que, após o desemprego, por não conseguirem empregos do mesmo status ou com melhores salários, recorreram ao trabalho informal como estratégia de sobrevivência. A questão da identidade profissional chamou a atenção na medida em que esses desempregados perderam suas identidades profissionais como trabalhadores fabris, bancários, técnicos e pequenos empresários, passando a ser pouco valorizados na sociedade por causa do subemprego.

Ainda no subitem 4.1, são analisados os seguintes dados: idade, sexo, origem dos trabalhadores, escolaridade e inserção no mercado de trabalho, isto é, a primeira ocupação ou emprego. Os motivos de saída da ocupação anterior e de inserção na ocupação atual confirmam a hipótese de que o desemprego e a falta de opção são as principais causas de permanência na informalidade. Os meios de conseguir trabalho a partir das redes de sociabilidade demonstram a importância da integração social entre esses sujeitos. As organizações dos trabalhadores, seja na forma de movimentos sociais, sindicatos, ou colônias estiveram presentes nos discursos de alguns entrevistados de maneira crítica. Além disso, o subitem 4.1 comporta discussões sobre a identidade social dos trabalhadores desempregados e daqueles no trabalho informal (desemprego oculto por trabalho precário) entrevistados na minha pesquisa. 
Os subitens 4.2, 4.3 e 4.4 procuram destacar algumas questões que nos parecem relevantes na discussão das trajetórias sociais e ocupacionais. Apesar de não representarem a maior parte dos desempregados, as mulheres, jovens e idosos têm presença significativa no mercado informal. Além disso, podemos considerar que esses trabalhadores se encontram em condições mais vulneráveis na informalidade.

Se antes as mulheres menos qualificadas desempenhavam atividades informais e precárias por tradição cultural, hoje o fazem por falta de alternativas. Responsáveis pelo trabalho doméstico não remunerado, desenvolvem "bicos" para complementar a renda dos maridos ou, como chefes de família e mães solteiras, submetem-se a várias ocupações profissionais, tanto como assalariadas sem carteira, subempregadas, quanto autônomas.

Os jovens encontram como barreira a falta de experiência, em primeiro lugar. Existe a dificuldade de adesão à escola, seja devido à jornada de trabalho prolongada, ou à falta de interesse pelo sistema educacional, pouco estimulante e inadequado à realidade dos alunos. Com pouca escolaridade e qualificação, acabam permanecendo por longos períodos em atividades informais até encontrarem um emprego. Com o passar dos anos, torna-se mais difícil voltar a estudar e tentar oportunidades melhores. Esse fato é agravado nos casos em que os jovens constituem família precocemente. Estes precisam se dedicar totalmente a trabalhos e "bicos" que estejam ao seu alcance, com poucas chances de mudar sua trajetória.

A maioria dos idosos pesquisados já se aposentou, mas busca complementação de renda no mercado informal. $\mathrm{O}$ valor da aposentadoria costuma ser de um salário mínimo. Foi encontrado número expressivo de trabalhadores que não recebe qualquer beneficio, pois não têm tempo de contribuição suficiente para obter aposentadoria. Após as crises econômicas na década de 90, vários ficaram desempregados e foram obrigados 
a se inserir em ocupações precárias. As trajetórias incertas são comuns entre trabalhadores que chegam à velhice sem qualquer direito. Mais preocupantes são os casos de trabalhadores idosos que exercem o papel de chefes de família, enquanto os filhos estão desempregados. A própria aposentadoria ou renda obtida em "bicos" serve para sustentar filhos e inclusive netos.

O subitem 4.5 analisa as condições de vida e renda dos vendedores ambulantes, catadores de materiais recicláveis, pescadores de lagosta e colhedores de laranja. Percebe-se que as condições de vida estão diretamente relacionadas aos rendimentos e ao salário recebidos pelos trabalhadores. Entre as condições de vida, são considerados os seguintes aspectos: moradia, infraestrutura do local de moradia, acesso à assistência de saúde pública, transporte e consumo de bens materiais, entre outros. À época da pesquisa, a maioria da população estudada recebia de um a dois salários mínimos. Os vendedores ambulantes alcançavam renda maior, isto é, até três salários mínimos em média por mês durante o ano.

Com exceção dos catadores de materiais recicláveis, a maioria dos entrevistados tem casa própria, com poucos cômodos, construída por eles próprios. Os casos mais graves são de catadores que moram nas ruas e trabalhadores obrigados a pagar aluguel. A moradia costuma estar situada em locais mais simples nos bairros de periferia, ou nos pequenos municípios. A infraestrutura, como saneamento básico e transportes, nem sempre é satisfatória. As condições de assistência à saúde são precárias devido à falta de hospitais ou prontos-atendimentos e à ausência de profissionais de saúde, entre outros problemas. Esses fatos dificultam o atendimento nos casos de emergência ou para o tratamento de doenças crônicas. Os trabalhadores costumam adquirir bens de consumo, como fogão, geladeira, freezer, televisão e aparelho de som através de crediário e financiamento. 


\subsection{Trajetórias sociais e profissionais}

\subsubsection{Idade e sexo}

Percebeu-se, no meu estudo, a presença significativa de trabalhadores do sexo masculino com mais de 40 anos entre os catadores de materiais recicláveis, vendedores ambulantes e colhedores de laranja. No caso dos pescadores de lagosta, a maioria possui mais de 30 anos. Foram encontradas pessoas mais jovens e outras com mais de 60 anos em todas as ocupações estudadas. Parte expressiva da população pesquisada é formada por sujeitos que se encontravam na fase de vida economicamente ativa. A questão da maturidade e da experiência na atividade informal foi considerada um aspecto importante na trajetória profissional dos sujeitos.

A ECINF $2003^{253}$ demonstrou que os autônomos e trabalhadores por contaprópria do sexo masculino foram estimados em 6,2 milhões $(65,3 \%)$, contra 3,3 milhões (34,7\%) de mulheres. Em relação à idade, a maior concentração de autônomos e trabalhadores por conta própria ocorre nas faixas de 25 a 39 anos e de 40 a 59 anos, com um total de $82,9 \%$ de pessoas de ambos os sexos nessas faixas; a idade preponderante é verificada na segunda faixa, com $45,6 \%$ das pessoas, sugerindo que os negócios

\footnotetext{
253Pesquisa da Economia Informal Urbana/2003/IBGE/SEBRAE (ECINF, 2003): pesquisa desenvolvida pelo Instituto Brasileiro de Geografia Estatística (IBGE) com a colaboração do Serviço Brasileiro de Apoio às Micro e Pequenas Empresas (SEBRAE). Os dados levantados referem-se ao Brasil, a cada Estado, ao Distrito Federal e às Regiões Metropolitanas de Belém, Fortaleza, Recife, Salvador, Vitória, Belo Horizonte, Rio de Janeiro, São Paulo, Curitiba, Porto Alegre e Goiânia. A ECINF é uma pesquisa por amostra de domicílios situados em áreas urbanas. $\mathrm{O}$ universo das atividades informais pesquisadas compreende as unidades econômicas não-agrícolas com até cinco empregados e o trabalho por conta-própria, produtores de bens e serviços e o comércio, situados nas áreas urbanas. Foram considerados empreendimentos informais, de acordo com as recomendações da Organização Internacional do Trabalho (OIT), todas as empresas com até cinco empregados e as pertencentes a trabalhadores por conta-própria, independentemente de possuírem ou não constituição jurídica. Esse conceito de informalidade visa refletir o conjunto de unidades caracterizadas por iguais modos de funcionamento, independentemente de sua condição legal. São informais em termos econômicos e organizacionais (estrutura de produção, emprego de mão-de-obra, rendimentos etc.). As unidades apresentam as características de baixa escala de produção, organização gerencial simples e quase nenhuma separação entre capital e trabalho. Os resultados da pesquisa ECINF 2003 podem ser acessados no site do IBGE: www.ibge.gov.br ou no site do SEBRAE: www.sebrae.com.br.
} 
informais constituem uma oportunidade de ocupação importante para as pessoas de idade mais avançada.

A ECINF 2003 também mostra que 72,5\% dos trabalhadores assalariados ou ocupados nos negócios informais (assalariados sem carteira) do sexo masculino se encontram na faixa de 18 a 39 anos, contra $65,6 \%$ das mulheres; a partir da idade de 40 anos, há uma nítida diferença entre os sexos, com a proporção de homens em 14,8\% e um maior percentual de mulheres, na cifra de $24 \%$. As informações confirmam os dados encontrados entre os colhedores de laranja e os pescadores de lagosta.

Os dados encontrados em meu estudo entre os vendedores ambulantes estão de acordo com as observações realizadas por MELO \& TELES ${ }^{254}$ na pesquisa sobre o comércio ambulante na cidade do Rio de Janeiro. A faixa etária de 26 a 45 anos representa em média mais da metade do total de ocupados no comércio ambulante. Esse fato demonstra um perfil de adultos no auge de seu ciclo de vida produtiva e também indica a impossibilidade de reverter sua posição na ocupação, à medida que o exercício de outro tipo de atividade é apenas dificilmente alcançado por essa mão-de-obra. Em geral, falta-lhe experiência, qualificação profissional e até mesmo disciplina para o desempenho de atividades em escritórios ou fábricas.

Segundo os autores, a faixa de 26 a 35 anos representa a de maior peso dentro da atividade informal em questão. Tal situação se deve à falta de opção de emprego formal e ao fato do mercado exigir uma experiência que o trabalhador não possui, induzindo-o inclusive a obter essa experiência numa ocupação informal. Já entre aqueles na faixa de 36 a 45 anos, observa-se uma falta de opção ainda maior, devido à idade mais avançada. Esse fato pode ser observado pelo peso da faixa etária na composição dos ocupados no comércio ambulante. A faixa de 46 a 55 anos ou mais apresenta uma tendência

254 MELO, Hildete Pereira de; TELES, Jorge Luiz (2000). Serviços e Informalidade: o comércio ambulante no Rio de Janeiro. Texto para Discussão n 773 , Instituto de Pesquisa Aplicada (IPEA), Rio de Janeiro, dezembro. 
crescente no período estudado, o que demonstra que a dificuldade de conseguir um emprego formal possui maior influência na decisão dos trabalhadores dessa faixa de ir para o comércio ambulante do que a tentativa de complementar a renda com uma aposentadoria baixa.

Como as demais atividades ligadas à economia informal, o comércio ambulante não se apresenta como um fenômeno transitório fadado a desaparecer num futuro previsível da economia nacional e mundial. Essa atividade se caracteriza por ser uma estratégia de sobrevivência ou um subemprego.

\subsubsection{Origem}

Dos entrevistados, a maioria dos vendedores ambulantes nasceu na região Sudeste. Entre os catadores de materiais recicláveis, as origens se dividem entre as regiões Nordeste e Sudeste. Os colhedores de laranja são da região Sudeste e os pescadores, da Nordeste. A partir dessas informações, não é mais possível afirmar que os vendedores ambulantes, catadores de matérias recicláveis e colhedores de laranja migraram do Nordeste, como fizeram as gerações passadas. Hoje, é possível encontrar camelôs, catadores e colhedores nascidos e criados em cidades na região Sudeste, inclusive em São Paulo, que no passado era considerada a mais desenvolvida economicamente. Os que não nasceram na região Sudeste já vivem no estado de São Paulo há mais de 20 anos.

A pobreza da capital paulista não deve ser atribuída aos nordestinos que vieram a São Paulo em busca de trabalho. Antes, é sinal de que a população originária da 
metrópole convive com os problemas do desemprego, das desigualdades e da pobreza. A questão da baixa escolaridade e da evasão escolar nos grandes centros urbanos está presente. $\mathrm{O}$ aumento da População Economicamente Ativa, contando os nativos e migrantes, a diminuição de postos de trabalho no mercado formal, o aumento de trabalhadores no mercado informal e os rendimentos baixos contribuíram para a crise econômica e, consequentemente, para o aumento das desigualdades e da pobreza.

Para trabalhadores com pouca escolaridade, sem qualificação e com menores chances de disputar vagas no mercado formal, resta aceitar fazer "bicos", abrir pequenos negócios e ser conta-própria para sobreviver. É comum ouvir os sujeitos dizerem: “a gente tem que se virar"; "a gente se vira como pode"; "precisamos comer e não tem saída... O que dá pra fazer a gente faz", em atitude de revolta e tristeza diante da situação. Os entrevistados costumam buscar emprego ao mesmo tempo em que realizam "bicos" e atividades informais. Há resistência antes de aceitar a inserção ou permanência no mercado informal.

Nascidos e criados na região Nordeste, os pescadores de lagosta costumam permanecer no local de nascimento, ou nas cidades mais próximas e não demonstram interesse em migrar para capitais na região Nordeste e nem para outras regiões no país. Argumentam que "se é para passar fome, ganhar pouco, é melhor ficar onde estão. Lá têm família, amigos, casa e alimento tirado da roça e do mar. Têm os costumes”. O sonho de ganhar a vida e enriquecer na região Sudeste, por exemplo, não é compartilhado entre eles.

Todos disseram conhecer algum familiar ou colega que tentou a sorte no Sudeste e voltou para a cidade natal. As experiências relatadas não foram positivas, o que reforçou a decisão dos trabalhadores de permanecer no Nordeste, em sua cidade de origem. Existe o medo da produção na pesca diminuir devido à pesca predatória e o 
aumento do número de pescadores. Esses trabalhadores sabem que a falta de trabalho na região forçaria sua migração para cidades com maiores oportunidades de trabalho. Alguns pensam em abrir um pequeno negócio, trabalhar na pecuária, na criação de camarão, ou na construção civil como alternativa ao desemprego.

O mesmo fenômeno foi observado entre os catadores de laranja no interior de São Paulo. Nenhum demonstrou interesse em migrar para São Paulo, por exemplo, em busca de melhores rendimentos ou perspectivas. Entre os camelôs e catadores de materiais recicláveis, vários migrantes desejam juntar dinheiro para que no futuro possam voltar ao local de origem nas várias regiões no país, principalmente no Norte e Nordeste. Argumentam que não compensa permanecer na metrópole, por estarem longe de familiares e também devido à violência, ao aumento da concorrência, aos baixos rendimentos e à péssima qualidade de vida. Mesmo com todos os problemas, alguns ainda arriscam trazer familiares de lugares distantes para tentar a sorte e trabalhar junto com eles em São Paulo ou no Rio de Janeiro.

\subsubsection{Escolaridade}

Dentre os trabalhadores informais pesquisados, o maior grau de escolaridade foi encontrado em meio aos vendedores ambulantes. Foram entrevistados três camelôs que cursaram ou estavam cursando o nível superior; nove que cursaram ou estavam cursando o ensino médio ou técnico; e oito que cursaram ou estavam cursando o ensino fundamental. Para os catadores de materiais recicláveis, catadores de laranja ${ }^{255} e$

255 O Censo Agrário 2006 revelou que cerca de 4,6 milhões dos trabalhadores em estabelecimentos agropecuários eram analfabetos. Do total de ocupados em estabelecimentos agropecuários, 6,5\% (ou 1.076.890) tinham menos de 14 anos de idade. Censo Agropecuário 2006. http: www.ibge.gov.br . Consulta no dia 
pescadores prevalece o ensino fundamental incompleto, tendo sido encontrados analfabetos e pessoas que cursaram até a $4^{\circ}$ série do ensino fundamental e não sabem ler, nem escrever, exceto para assinar o próprio nome. O nível de escolaridade baixa, a falta de qualificação e a idade avançada têm peso fundamental para a permanência em atividades informais e precárias. Na ECINF $2003^{256}$ é observado que a maioria dos trabalhadores por conta-própria e autônomos possui escolaridade e qualificação baixas. Um número expressivo de trabalhadores possui apenas o primeiro grau incompleto.

Para MELO \& TELES $^{257}$, em seu estudo sobre o comércio ambulante, os trabalhadores aumentaram a escolaridade ao longo da década de 90 em todas as regiões metropolitanas, embora ainda seja significativa a participação dos analfabetos nesse ramo de atividade. No Rio de Janeiro, os ambulantes "sem instrução" foram e seguem sendo uma parcela minoritária. A faixa educacional predominante é de cinco a oito anos de estudo, que se manteve relativamente constante ao longo do período, variando entre $35 \%$ e $40 \%$ dos entrevistados e tendo apresentado um suave aumento até 1998.

Segundo os autores, o grupo de pessoas com nove a onze anos de estudo, ou seja, trabalhadores que possuem o segundo grau completo ou incompleto, apresentou um crescimento muito significativo, da ordem de $42 \%$. No final da década de 90 , o número de ambulantes que possuem segundo grau atingiu $1 / 4$ do total. $\mathrm{O}$ aumento da escolaridade dos ambulantes se deu, em parte, devido ao crescimento do grupo com nível de instrução de anos ou mais, que se expandiu em $1 / 3$ na região metropolitana fluminense no período estudado.

Podemos dizer, portanto, que o comércio ambulante cada vez menos representa um refúgio para os menos escolarizados. A participação de pessoas qualificadas nesse

01/10/2009. Departamento Intersindical de Estatística e Estudos Socioeconômicos (DIEESE) e Ministério do Desenvolvimento Agrário (MDA) (2008). Estatísticas do meio rural. Brasília: MDA: DIEESE, 280p, http://www.dieese.org.br, consulta no dia: 28/09/2009. 256 ECINF 2003, IBGE/SEBRAE.

257 MELO, Hildete Pereira de; TELES, Jorge Luiz (2000). Serviços e Informalidade: o comércio ambulante no Rio de Janeiro. Texto para Discussão n 773 , Instituto de Pesquisa Aplicada (IPEA), Rio de Janeiro, dezembro. 
tipo de atividade vem apresentando tendência crescente, com taxa de crescimento de 40,7\% para o grupo de nove a onze anos de estudo e de $31,1 \%$ para o grupo com 12 anos ou mais de estudo. Nessa perspectiva, ao contrário do que suspeitavam as abordagens que explicam o mercado informal como uma precarização da mão-de-obra, ocorre uma tendência clara ao crescimento do grau de escolaridade e da qualificação do ocupado no comércio ambulante.

Em meu estudo, os vendedores ambulantes são os que apresentam maior nível de escolaridade. Um número significativo está cursando o ensino médio, ou possui este nível completo. Alguns entrevistados estão cursando faculdade, ou têm nível universitário. O mais preocupante é encontrar indivíduos que decidem estudar em um segundo curso superior, na tentativa de conseguir melhor inserção no mercado de trabalho. Muitos participam de cursos preparatórios para concursos públicos. As vantagens de ter emprego estável, da garantia do salário no final do mês e de receber benefícios são os principais motivos de interesse para a inserção ocupacional em órgãos públicos. Esse fato demonstra que a dificuldade para encontrar emprego não mais se circunscreve aos redutos de baixa escolaridade, mas tem atingido todos os níveis educacionais.

A experiência de desemprego entre pescadores de atum no estado da Paraíba, identificada em pesquisa realizada em 2008, demonstra que a maior dificuldade de reinserção profissional após a perda da ocupação é a escolaridade baixa. A maioria estava há mais de dez anos na profissão e tinha em média mais de 30 anos de idade, tendo cursado até a $4^{\circ}$ série do ensino fundamental. Todos eram assalariados com carteira de trabalho na pesca comercial do atum. Trabalhavam em barcos espanhóis, chineses e chilenos, entre outros. Devido à situação irregular, as embarcações foram eram obrigadas a deixar a costa brasileira e os pescadores brasileiros ficaram 
desempregados. Como não tinham tempo de trabalho para obter aposentadoria, viviam graças ao FGTS e ao seguro-desemprego. Sabiam que um dia o dinheiro acabaria. Antes que isso acontecesse, a maioria fazia "bico", os pescadores trabalhando como assalariados sem carteira de trabalho na pesca "artesanal" 258259 do camarão e lagosta, entre outras ocupações.

Os entrevistados disseram que só sabiam trabalhar no mar, pois era o que tinham feito a vida inteira. Afirmaram que gostariam de entrar para a Marinha Mercante, mas a falta de escolaridade era um empecilho. Comentaram que era difícil voltar a estudar por causa do trabalho e da dificuldade de aprender. Frente às perspectivas, esperavam poder retornar para a pesca comercial, em que recebiam três vezes mais que na pesca artesanal, tinham carteira de trabalho assinada e direitos. Esperavam que a situação dos barcos estrangeiros fosse regularizada ou que aparecessem outras oportunidades na pesca comercial.

O Sindicato dos Trabalhadores Marítimos e Portuários de Cabedelo, na Paraíba, e a Prefeitura do município, onde existe um dos principais terminais pesqueiros no Nordeste, realizaram várias tentativas de educação de pescadores. No início, vários trabalhadores participavam, mas com o tempo desistiam por inúmeros motivos. Não era possível colocar os estudos como prioridade em suas vidas. Necessitavam trabalhar "na primeira oportunidade que aparecesse” para sustentar a família. O estudo não fazia parte

\footnotetext{
258 Pesca artesanal é um tipo de pesca caracterizada principalmente pela mão-de-obra familiar, com embarcações de porte pequeno, como canoas ou jangadas. Sua área de atuação está nas proximidades da costa e nos rios e lagos. Os equipamentos variam de acordo com a espécie a capturar (rede de cerco, emalhe, arrasto simples, arrasto duplo, tarrafa, linha e anzol, armadilhas e outras). http://pt.wikipedia.org. Consulta realizada em 10/07/2008. Os barcos são registrados na Marinha Mercante como de pesca artesanal, mas na verdade o trabalho desenvolvido tem características de pesca comercial. O armadores (donos de barcos) possuem várias embarcações pequenas com documentos em nome de diferentes pessoas. Costumam contratar informalmente pescadores para trabalhar na pesca. Esses não constituem mão-de-obra familiar. A característica da relação de trabalho é de assalariamento. Nessa perspectiva, a pesca da lagosta, na minha pesquisa, pode ser considerada pesca comercial.

259 Segundo o último Recadastramento Nacional dos Pescadores do Brasil, divulgado em dezembro de 2006 pela antiga Secretaria Especial de Aqüicultura e Pesca (Seap) - atual Ministério da Pesca e Aquicultura (MPA) - , há 390,7 mil pescadores registrados na Marinha no país. O levantamento anterior, que havia ocorrido 40 anos atrás, tinha identificado 500 mil. De acordo com o cadastro, duas de cada cinco pessoas que sobrevivem da pesca artesanal moram na região Nordeste. A OIT estima em 2 milhões de pescadores na América Latina. Dos quais o Brasil responde por 1,24 milhão, sendo quase 1 milhão de pescadores artesanais. Segundo dados da relação Anual de Informações Sociais (Rais), a atividade pesqueira fechou o ano de 2008 com apenas 9.296 empregos formais. O índice de informalidade do setor é um dos mais altos do país. Segundo estimativas do Ministério Público do trabalho (MPT), cerca de $90 \%$ dos pescadores não possuem carteira de trabalho assinada. (Repórter Brasil - 14/09/09 - Trabalhador da pesca lida com precariedade e má remuneração).
} 
da cultura desses trabalhadores. Apesar disso, esperavam que os filhos estudassem, tivessem uma profissão e um futuro melhor.

Os pescadores de lagosta de meu estudo comentaram que, apesar de acharem o estudo importante, era inviável, pois passavam praticamente sete meses no mar. A Prefeitura de Acaraú, no interior do Ceará, procurou desenvolver um programa chamado "Pescando Letras"260, para incentivar os pescadores a estudar. A monitora disse que, no início, havia boa adesão. Mas os pescadores acabavam se desinteressando e desistindo do curso, principalmente ao encontrar dificuldade no aprendizado, ou arrumavam algum "bico"261 para complementar a renda do seguro-defeso.

Os catadores de materiais recicláveis jovens demonstravam interesse em retornar aos estudos, principalmente quando estavam inseridos nas cooperativas de materiais de reciclagem. Com a vida disciplinada e afastados dos consumos de drogas e bebidas alcoólicas, conseguiam traçar metas para conseguir ocupações melhores. O mesmo fenômeno pôde ser observado entre os colhedores de laranja jovens. Alguns desejavam voltar à escola e conseguir uma atividade menos penosa. Mas os vendedores ambulantes, mesmo na maturidade, eram os mais interessados em melhorar sua qualificação - o que estaria relacionado ao nível de escolaridade maior, com poucas interrupções e repetências no processo escolar.

260 Secretaria Especial de Aqüicultura e Pesca (SEAP). 


\subsubsection{Inserção no mercado de trabalho: a primeira ocupação}

Foi observado que a primeira inserção no mercado de trabalho ocorreu de maneira diferenciada nas ocupações estudadas. Os vendedores ambulantes ingressaram no mercado com idade média de 15 anos. É possível que até esse momento eles estivessem estudando e buscando qualificação. Na primeira ocupação, a maioria foi assalariada sem carteira de trabalho ${ }^{262}$ e poucos tiveram experiência de serem trabalhadores por conta-própria ${ }^{263}$, ou participarem de trabalho familiar ${ }^{264}$. Nota-se a presença significativa de jovens que tiveram carteira de trabalho assinada ${ }^{265}$ no primeiro emprego - quase a metade dos entrevistados. Esse fato pode estar relacionado à maior escolaridade e à forte fiscalização do trabalho nos centros urbanos das regiões Sudeste e Sul. Não podemos afirmar que o mesmo aconteceu no interior dos Estados, na zona rural, e nas demais regiões no país.

Os catadores de materiais recicláveis foram inseridos no mercado de trabalho antes dos doze anos, sendo que uma parcela importante de crianças com menos de dez anos exercem a função. Esse aspecto também foi observado entre os pescadores de lagosta e colhedores de laranja. Nessa situação, prevaleceu o sistema de trabalho familiar, em que os jovens ajudavam seus pais na lavoura, na roça, na criação de animais e na pesca. Alguns trabalharam como assalariados sem carteira, apesar da pouca idade. Eles costumavam capinar, plantar, colher milho, café, soja, mandioca e laranja, preparar enxerto de mudas, cuidar dos animais, tirar e vender leite, pescar e puxar rede.

\footnotetext{
262 Auxiliar de escritório; limpador de vidros; bóia-fria; colhedor de frutas; empregada doméstica; cuidadora de crianças; entregador de mercadoria para clientes dos comércios.

263 Vendedores de balas, doces e salgados nas feiras livres e faróis. $264 \mathrm{Na}$ lavoura e roça, principalmente.

265 Em funções como aprendiz de embalagem na indústria de transformação; recepcionista; ajudante geral na indústria de calçados; ajudante geral na indústria têxtil; office boy; técnico de agronomia, auxiliar de serviço geral.
} 
Após a primeira experiência, os catadores, pescadores e colhedores de laranja chegaram a ser reinseridos no mercado como assalariados sem carteira de trabalho e por conta-própria. Desenvolveram as seguintes funções: ajudante de pedreiro, jardineiro, bóia-fria, entregador de gás, montador de bijuterias, empregada doméstica, lavadeira, vendedor ambulante de balas e salgados, carregador de compras na feira, lavador de carros, limpador de vidro de carro, entre outras. Não foram encontrados trabalhadores contratados como aprendiz entre os 14 e 15 anos no primeiro emprego.

\subsubsection{Ocupações no mercado formal e informal}

A maioria dos trabalhadores entrevistados teve alguma experiência de trabalho com carteira assinada. Entre os pescadores, foram raros os casos de trabalho registrado em carteira. Constatou-se que, em todas as ocupações estudadas, alguns indivíduos nunca tiveram emprego estável, principalmente os jovens. Um número expressivo de trabalhadores teve mais tempo de trabalho como assalariado sem carteira registrada, conta-própria e trabalhador familiar do que assalariado com carteira de trabalho. Esse fato era preocupante para os trabalhadores, pois significava a falta de perspectivas para uma aposentadoria ${ }^{266}$.

Entre os catadores de materiais recicláveis, camelôs e colhedores de laranja foi encontrado um número expressivo de sujeitos que tiveram experiência de trabalho na Indústria e Serviços ${ }^{267}$. Alguns desenvolveram atividades em funções que exigiam

\footnotetext{
266 Até o momento dessa pesquisa, a situação dos colhedores de laranja e pescadores de lagosta estava sendo regularizada. O processo começou há um ano por determinação do Ministério do Trabalho. Houve forte atuação da fiscalização na área rural e na pesca em decorrência de acidentes e mortes no trabalho precário. 267 Em funções como aprendiz; ajudante geral; auxiliar de serviços gerais; operador de máquinas; auxiliar de produção; prensista; ferramenteiro; colador de sola de sapato/montador de calçados; empacotador nas máquinas; funileiro; ajudante de pedreiro; pedreiro; auxiliar de escritório; auxiliar administrativo; bancário;
} 
maior qualificação e propiciavam "status" social em sua trajetória profissional. Outros tiveram apenas experiências de trabalho em funções que não exigiam qualificação e não davam prestígio. A maioria dos entrevistados tinha baixa escolaridade, o que não contribuía para que conseguissem melhores ocupações.

Como um número significativo de entrevistados em meu estudo têm experiência na indústria, cito alguns dados sobre mobilidade ocupacional - isto é, a migração entre os setores formal e informal de trabalhadores desempregados. COMIN $^{268}$, em seu estudo longitudinal com trabalhadores do município de Diadema, destacou certas características como idade; cor; grau de instrução (nível de escolaridade); nível de remuneração; ocupação $(\mathrm{CBO})^{269}$; ramo de atividade da empresa; e localização geográfica como fundamentais na trajetória ocupacional do trabalhadores rumo à informalidade.

COMIN $^{270}$ também observou que do ponto de vista da natureza dos vínculos, as relações formais de trabalho representavam, em 1989, nada menos que $90 \%$ do total das ocupações, proporção que se reduz, em 1999, para 68\%. Ao mesmo tempo, as ocupações por conta-própria ou autônomas tiveram seu número multiplicado por quatro ao longo do período, chegando a representar 1/4 do total das ocupações em 1999. A proporção dos trabalhadores que trocaram de grupo ocupacional ao longo do período foi elevada, ficando em torno de $60 \%$. Isso ocorreu entre trabalhadores menos qualificados,

auxiliar de enfermagem; pesquisador de mercado; promotor de vendas; técnico agrimensor; operador de caixa; repositor de mercadorias no comércio; vendedor; recepcionista; limpador de vidros; faxineiro; empregada doméstica; cozinheiro; lavadeira; passadeira; padeiro; motorista; office-boy; bóia-fria; colhedor de laranja; cortador de cana-de-açúcar; catador de lixo; jardineiro; catador de materiais recicláveis; separador de materiais recicláveis no ferro-velho; cobrador de perua Kombi; cobrador de ônibus; vigia/segurança; vendedor ambulante; camelô; dono de pequenos negócios, como bares, lanchonetes e comércios, etc. 268 COMIN, Álvaro A. (2003). Migrações entre formal e informal: um survey com trabalhadores. Série Estudos e Pesquisas. Salvador, Bahia, volume 66, p. 6378; COMIN, Álvaro A. (2003). Mudança na estrutura ocupacional do mercado e trabalho em São Paulo. Tese apresentada ao Programa de Pós-Graduação em Sociologia da Faculdade de Filosofia, Letras e Ciências Humanas da Universidade de São Paulo. 269 CBO: Classificação Brasileira de Ocupações. 270 COMIN, Álvaro A. (2003). 
como por exemplo os trabalhadores manuais ${ }^{271}$, desprovidos de um saber técnico claramente identificável, e os trabalhadores não-manuais de rotina ${ }^{272}$.

A qualificação é um quesito importante de estabilização, ou pelo menos de nãoregressão no mercado de trabalho. Os trabalhadores qualificados (trabalhadores manuais especializados $^{273}$, técnicos e profissionais ${ }^{274}$ ) vão parar no desemprego aberto, o que talvez esteja relacionado a uma maior esperança de reconquistar uma colocação nos mesmos moldes de sua ocupação anterior. Pode existir reconversão para o setor formal, embora ela talvez não seja duradoura. Desta maneira, percebe-se uma elevada rotatividade.

Em relação à faixa etária de 30 a 50 anos, o pesquisador observou uma das maiores taxas de desemprego aberto em dezembro de 1999. Essa faixa é a que concentra a maior proporção de brancos e a menor de negros, com uma forte proporção de migrantes (especialmente nordestinos) - a maioria estabelecida no município de Diadema há mais de 20 anos. Predominam os trabalhadores manuais especializados, com vínculos contínuos de mais de seis anos numa ocupação anterior, em 1989. O perfil educacional não apresenta discrepâncias relevantes frente à média do conjunto dos entrevistados, sendo esse o grupo que apresenta melhor renda, com 2/3 dos trabalhadores ganhando acima de sete salários mínimos.

Para $\mathrm{COMIN}^{275}$, os desempregados da indústria que migraram para o comércio em pouco tempo e não retornaram à ocupação anterior - ou seja, os expulsos do emprego industrial - tiveram dificuldades de reinserção, devido principalmente a seu perfil etário. Esses indivíduos tinham mais de 50 anos em dezembro de 1999 e eram

\footnotetext{
271 Trabalhadores manuais: carregadores, ajudantes gerais, faxineiros, porteiros, embaladores, ensacadores.

272 Trabalhadores não-manuais de rotina: funções predominantemente ligadas a atividades comerciais como vendedores, vendedores ambulantes, balconistas e cobradores, entre outras.

273 Trabalhadores manuais especializados: funções com especialização definida como marceneiros, ferramenteiros, torneiros, pintores, eletricistas e congêneres. 274 Técnicos e profissionais: profissões que exijam explicitamente formação específica equivalente ao segundo ou terceiro graus: desenhistas, engenheiros e programadores, entre outras. 275 COMIN, Álvaro A. (2003).
} 
quase todos autônomos, trabalhando principalmente como ambulantes. Eram migrantes há muito estabelecidos em Diadema, sendo que em 1989, a maioria se encontrava empregada, com vínculo registrado há mais de dez anos. O número de brancos era equivalente ao de não-brancos. Podemos dizer que a condição de autônomo oculta uma maior heterogeneidade do ponto de vista da remuneração. Os entrevistados possuíam um perfil educacional não muito distante da média. Esses indivíduos, com larga experiência em ocupações industriais qualificadas, viram seu capital profissional evaporar ao serem obrigados a migrar para outros ramos de atividade no setor terciário.

No grupo dos serviços, encontravam-se indivíduos com idade entre 25 e 40 anos, mais da metade nascida fora do Estado (no Nordeste, principalmente) e mais da metade vivendo há mais de vinte anos em Diadema. A maioria (54\%) era constituída por autônomos e 1/3, de assalariados formais, com predominância de trabalhadores manuais especializados (pintores, pedreiros e marceneiros); em 1989, a maior parte não estava empregada, ou estava há menos de três anos na atividade; $6 \%$ dessas pessoas estavam desempregadas em 1999.

Os resultados permitem observar, segundo $\mathrm{COMIN}^{276}$, o padrão de mobilidade ocupacional que leva à compreensão da migração do setor formal para o setor informal, como também ajudam a entender a inserção no mercado informal de trabalho conforme as características dos indivíduos, sugerindo maneiras mais ou menos bem-sucedidas de adaptação. Nesta perspectiva, o estudo de COMIN aponta a importância de elaborar políticas voltadas para a requalificação e reinserção ocupacional do amplo contingente de desempregados - o que constitui uma das questões mais críticas, que necessita intervenções de várias esferas do governo.

276 COMIN, Álvaro A. (2003). 


\subsubsection{Motivos de saída da ocupação anterior}

Os motivos da saída da ocupação anterior dependiam do fato do trabalhador ser assalariado ou por conta-própria. Foi encontrado maior número de assalariados com carteira assinada ${ }^{277}$ na ocupação anterior entre os vendedores ambulantes. É possível que esse fato esteja relacionado com o maior nível de escolaridade dos camelôs e, consequentemente, aos salários mais altos que recebiam na ocupação anterior. Foi encontrado um número significativo de sujeitos com nível médio e superior. Percebeuse a profissão de bancário, auxiliar de enfermagem, metalúrgico, operadora de caixa, promotor de vendas, auxiliar de escritório e escriturário entre esses trabalhadores.

$\mathrm{Na}$ minha pesquisa, a maioria dos trabalhadores assalariados com carteira de trabalho $^{278}$, os empregados, passou pela experiência de demissão na vida profissional. $O$ desemprego ocorreu nas décadas de 80 e 90, por motivos como cortes devido à crise econômica, a reestruturações produtivas, à terceirização; fechamento e falência de empresas. Foram raros os casos em que os entrevistados optaram pela informalidade como meio de obter melhores rendimentos, perspectivas, autonomia para se livrar de relações autoritárias de chefia e flexibilidade nos horários para poder cuidar de pessoas doentes na família e filhos, por exemplo.

$\mathrm{Na}$ verdade, frente à possibilidade de corte, enxugamento no quadro de funcionários, venda e falência das empresas, os trabalhadores empregados realizavam acordos e, com o dinheiro recebido na rescisão de contrato, procuravam investir em algum empreendimento. A necessidade de continuar lutando pela sobrevivência e a

277 A distribuição de trabalhadores com carteira de trabalho registrada na ocupação anterior foi a seguinte: pescador: nenhum; vendedores ambulantes ou camelôs: $\operatorname{sim}=11$; e não $=9$; catadores de materiais recicláveis: $\operatorname{sim}=9$; e não $=11$; colhedores de laranja: $\operatorname{sim}=6$; e não=14 . 278 A maioria dos pescadores de lagosta nunca esteve na situação de empregados, isto é, nunca tiveram carteira de trabalho registrada. Os pescadores trabalhavam em sistema de parceria com os donos dos barcos, apenas pagavam a Previdência Social como segurado especial para efeito de aposentadoria, auxílio doença e acidente. 
dificuldade de conseguir um novo trabalho no mercado formal fazia com que buscassem realizar "bicos" e trabalhos temporários. Enquanto isso, continuavam procurando por empregos e melhores oportunidades.

Os assalariados sem carteira, os subempregados na ocupação anterior, buscavam melhores rendimentos e perspectivas na nova atividade (como vendedores ambulantes, catadores de materiais recicláveis, colhedores de laranja e pescadores). Por se encontrarem em situação precária, recebendo salários baixos e muitas vezes atrasados; ficando sem pagamento; sofrendo pressão de patrões e encarregados para aumentar a produtividade, sem qualquer direito trabalhista e previdenciário, sem condições para competir no mercado de trabalho por melhores vagas e endividados, preferiam ficar desempregados, fazer "bicos", ou abrir seu próprio negócio.

Os que haviam sido conta-própria ${ }^{279}$ na ocupação anterior procuravam abrir um novo empreendimento após a falência e fechamento do antigo após desentendimentos entre sócios, divórcios, rendimentos baixos e falta de condições de trabalho. Alguns camelôs, por exemplo, tornaram-se catadores de materiais recicláveis devido às ações ostensivas da fiscalização da prefeitura para apreensão de mercadorias ("rapa") e por terem sido vítimas da violência da Guarda Municipal. Foi encontrada uma situação inversa. $\mathrm{O}$ catador de materiais recicláveis tornou-se camelô por causa do trabalho pesado e por problemas de saúde.

$\mathrm{Na}$ presente pesquisa, considero que a condição de desempregado envolve os seguintes aspectos: trabalhar em condições precárias; ter subempregos, na forma de assalariado sem carteira de trabalho; realizar "bicos" ou trabalhos temporários; ser conta-própria; ter pequenos negócios com pouca ou nenhuma tecnologia; ter rendimentos baixos; e ocupações que não exigem escolaridade e qualificação. Nessa 
perspectiva, os entrevistados, em sua maioria e em todas as ocupações pesquisadas, viviam há algum tempo como desempregados e informais, sendo inúmeros os casos de pessoas há mais de 15 anos no desemprego e/ou informalidade, incluindo a atual ocupação.

Percebe-se nas trajetórias sociais e profissionais analisadas, que após a demissão do emprego estável, grande quantidade de vínculos precários era mantida pelos indivíduos, assim como eram frequentes as mudanças de ramo nos períodos de transição entre empregos - isto é, era possível notar uma alta taxa de rotatividade no mercado de trabalho. O "desemprego prolongado" tornou-se "desemprego permanente", em particular entre os trabalhadores de mais idade, não-qualificados, com nível de escolaridade baixo e mais tempo na informalidade. Já o "desemprego provisório" ou “desemprego de curta duração" estava ligado àqueles mais jovens, com maior nível de escolaridade e que retornavam aos $\operatorname{estudos}^{280}$ em busca de melhor qualificação, na esperança de conseguir um emprego regular ${ }^{281}$. Esses estavam na informalidade há menos tempo - há até cinco anos, contando o período na atual ocupação.

Indagados sobre os usos Fundo de Garantia por Tempo de Serviço (FGTS), os trabalhadores disseram que usaram o dinheiro para comprar terreno; para a construção de uma moradia; reformar da casa; abrir um negócio próprio; pagar dívidas; e ajudar a família. Alguns comentaram que não receberam nada devido à falência e ao fechamento da empresa, entre outros motivos. Em relação ao seguro-desemprego, comentaram que as parcelas eram poucas, o valor baixo e que tiveram poucos meses para ir às agências de emprego, ver anúncios nos jornais e andar pelas ruas verificando placas. Além disso, tinham que gastar com conduções e alimentação fora de casa, o que custava caro.

280 Alguns procuravam completar os estudos, ensino fundamental, médio, técnico e tentam frequentar cursos de nível superior. Outros faziam cursos de língua estrangeira, computação entre outros.

281 Uma das saídas pensadas para o desemprego era prestar concursos públicos para conseguir emprego estável. 
Ao relacionarmos o desemprego à demissão de um assalariado com carteira de trabalho, estamos falando de um cidadão pleno em seus direitos trabalhistas. Recebia FGTS e seguro-desemprego, apesar do valor ser baixo; férias; e décimo terceiro salário, entre outros benefícios. Essa condição é diferente daquela observada junto aos que viviam a experiência do desemprego e trabalhavam no mercado informal há muito tempo. Nesta situação, os trabalhadores eram considerados "cidadãos de segunda classe", destituídos de cidadania e vítimas de exclusão social ${ }^{282}$.

NERI $^{283}$ confirma que nenhum segmento contribui mais para a pobreza brasileira do que o setor informal. Cerca de $51,3 \%$ dos pobres brasileiros estão em famílias chefiadas por informais. Os chefes de família desempregados contribuem apenas em 5,4\% da pobreza brasileira. Tal dado indica que a maior quantidade de pobres brasileiros não está no desemprego (desemprego aberto ${ }^{284}$ ), mas na informalidade (desemprego oculto ${ }^{285}$ ). São pessoas que trabalham, mas não ganham o suficiente para sustentar suas famílias. Segundo o autor, "pobre não pode se dar ao luxo de buscar emprego; pobre cai na informalidade".

A informalidade é mais frequente e crônica do que o desemprego. Pode-se dizer que, do ponto de vista individual, o desemprego é, em média, uma crise passageira. O aviso prévio, o FGTS e o seguro-desemprego amenizam os efeitos de curto prazo da perda do emprego formal. Por outro lado, não existe "seguro-informalidade", ou nada parecido. Para NERI, a informalidade constitui o principal "colchão" que alivia choques trabalhistas adversos para aqueles que não podem se dar ao luxo de buscar uma ocupação melhor.

282 SANTOS,W. G. (1979). Cidadania e justiça. Rio de Janeiro: Campus.

283 NERI, Marcelo (2006). Informalidade. Ensaios Econômicos, nº 635, Escola de Pós Graduação em Economia da Fundação Getúlio Vargas, Dezembro. 284 Desemprego aberto: pessoas que procuraram trabalho de maneira efetiva nos 30 dias anteriores ao da entrevista e não exerceram nenhum tipo de atividade nos últimos sete dias. www.seade.gov.br. Consulta realizada em 13/09/2009. 285 Desemprego oculto: pessoas que, para sobreviver, realizam trabalhos precários - algum trabalho remunerado ocasional de auto-ocupação - ou pessoas que realizam trabalho não-remunerado para ajudar em negócios de parentes e que procuraram mudar de trabalho nos 30 dias anteriores ao da entrevista ou que, não tendo procurado nada nesse período, o fizeram sem êxito até 12 meses atrás. www.seade.gov.br Consulta realizada em 13/09/2009. 
Uma das principais preocupações em relação ao trabalhador informal é a falta de cobertura dos programas de previdência social e de proteção trabalhista, o que significa a exclusão dos direitos de cidadania. É importante destacar a existência de desempregados de longo prazo (desemprego de longa duração) que, em alguns casos, até conseguem retornar ao mercado formal; ou de desempregados que transitam constantemente entre o formal e o informal, desenvolvendo diferentes atividades. Mais impressionantes são os casos de trabalhadores que nunca tiveram carteira de trabalho assinada na sua trajetória ocupacional, apesar estarem ocupados há anos. A própria estrutura de custos e benefícios associados à legislação trabalhista e previdenciária leva à informalidade, como modalidade de evasão fiscal. Essa informalidade deve ser combatida com a incorporação de incentivos "corretos" na legislação, que estimulem a formalização.

Vivemos a situação de cidadania regulamentada há pouco tempo na história no país. Além disso, deparamos com uma realidade em que menos da metade da População Economicamente Ativa (PEA) ${ }^{286}$ possui carteira de trabalho assinada e direitos. Sendo assim, é necessário refletir sobre a experiência dos indivíduos nos trabalhos com vínculos atípicos e precários, nas atividades informais, nos subempregos, nos pequenos negócios e na pobreza. Essa realidade assombra os europeus há algumas décadas, mas aqui no Brasil, sempre convivemos com a multiplicidade de relações de trabalho. A diversidade, com certeza, interferiu negativamente para formação da classe trabalhadora e a consciência de classe no país.

A atividade informal, com "bicos" e subemprego, significa "ganhar dinheiro para comer", "ter dinheiro para comprar coisas" e "ganhar o pão de cada dia". O trabalho não é um meio de emancipação, e sim de alienação. $O$ trabalhador não quer o 
"fim do trabalho" e nem a revolução. Deseja um trabalho, em muitos casos "qualquer trabalho", para poder "comer e pagar as dívidas" e "manter-se vivo ou sobreviver", mesmo estando sujeito à condição de exploração no modo de produção capitalista.

\subsubsection{Motivos de entrada na ocupação atual}

Os principais motivos de entrada dos entrevistados na ocupação atual foram o desemprego, a falta de opção devido à pouca escolaridade e qualificação para outras funções, a falta de experiência e poucas alternativas de ocupações na região em que moravam, em particular no caso dos pescadores e catadores de laranja. Para os trabalhadores que já se encontravam na informalidade na ocupação anterior, a inserção na atual ocupação se deve a melhores rendimentos e perspectivas. Os dados demonstram que as oportunidades de emprego e trabalho são maiores nas metrópoles do que na zona rural.

Os catadores de materiais recicláveis e camelôs ou vendedores ambulantes tiveram experiências em diversas ocupações, tanto no mercado formal, quanto informal. Mudaram mais de trabalho do que os pescadores de lagosta e colhedores de laranja durante sua trajetória profissional. Estes últimos trabalhadores permaneceram a maior parte da vida no interior de seus Estados e em municípios menores. Não tiveram tantas opções de emprego. A maioria trabalhou na agricultura, pecuária, pesca construção civil e trabalho doméstico. Foram raros os casos de pescadores e colhedores que trabalharam em funções qualificadas nas indústrias. 
Por falta de opção de emprego, um número expressivo de desempregados passa a trabalhar por conta-própria. Segundo dados da Pesquisa de Economia Informal Urbana (ECINF 2003) ${ }^{287}$, dos 10,3 milhões de negócios informais (unidades de produção), os trabalhadores por conta-própria representam a maioria, $88,0 \%(9,1$ milhões de unidades $)$ e os empregadores (donos de microempresas, donos de pequenos negócios com até cinco empregados), 12,0\% (1,2 milhões de unidades) do total.

Os principais grupos de atividades são o comércio e a reparação, construção civil e indústria. Os três grupos citados somam $66,2 \%$ de todos os negócios informais. Entre 1997 a 2003, os trabalhadores por conta própria aumentaram em 11,6\%, enquanto os empregadores diminuíram em 6,6\%. Os dados do ECINF 2003 confirmam que a grande maioria dos empresários informais é representada pelos trabalhadores por conta-própria. Segundo o ECINF 2003, os principais motivos que levam os trabalhadores a iniciar um negócio por conta-própria são a "falta de emprego" e a "complementação da renda familiar". Posso supor que a necessidade de fazer "bicos" e ter um negócio próprio se deve aos baixos salários, insuficientes para sobrevivência pessoal ou familiar.

A indicação para o subemprego e os "bicos" foi realizada principalmente por amigos, pessoas conhecidas e familiares na maioria das inserções e reinserções. Nessa perspectiva, percebe-se que a integração social é fundamental para conseguir trabalho. A importância das redes sociais foi observada em todas as ocupações estudadas. Era comum ouvir que o "pai”, "irmão", "primo", "amigo", "vizinho", “conhecido da

\footnotetext{
287 Pesquisa sobre economia informal urbana desenvolvida pelo Instituto Brasileiro de Geografia Estatística - IBGE com a colaboração do SEBRAE (Serviço Brasileiro de Apoio às Micro e Pequenas Empresas). Os dados levantados referem-se ao Brasil, aos Estados, ao Distrito Federal e às Regiões Metropolitanas de Belém, Fortaleza, Recife, Salvador, Vitória, Belo Horizonte, Rio de Janeiro, São Paulo, Curitiba, Porto Alegre e Goiânia. A ECINF é uma pesquisa por amostra de domicílios situados em áreas urbanas. $\mathrm{O}$ universo das atividades informais pesquisadas compreende as unidades econômicas não-agrícolas com até cinco empregados e o trabalho por conta-própria, produtores de bens e serviços e o comércio, situados nas áreas urbanas. Foram considerados empreendimentos informais, de acordo com as recomendações da Organização Internacional do Trabalho (OIT), todas as empresas com até cinco empregados e as pertencentes a trabalhadores por conta-própria, independentemente de possuírem ou não constituição jurídica. Esse conceito de informalidade visa refletir o conjunto de unidades caracterizadas por iguais modos de funcionamento, independentemente de sua condição legal. São informais em termos econômicos e organizacionais (estrutura de produção, emprego de mão-de-obra, rendimentos etc.). As unidades apresentam as características de baixa escala de produção, organização gerencial simples e quase nenhuma separação entre capital e trabalho. Os resultados da pesquisa ECINF 2003 podem ser acessados no site do IBGE: www.ibge.gov.br ou no site do SEBRAE: www.sebrae.com.br
} 
família" e "pessoal da igreja" indicou o entrevistado para um trabalho. O conhecimento da tarefa é construído a partir do senso comum. O aprendizado de como realizar o trabalho, montar um negócio e dos "macetes" ocorre de maneira informal e na experiência prática.

A entrada no mercado através de agências, placas e anúncios de jornais foi menos frequente nas ocupações pesquisadas. $\mathrm{O}$ fenômeno foi significativo entre os camelôs e catadores de materiais recicláveis. Os colhedores de laranja e pescadores de lagosta quase não tiveram esse tipo de experiência em sua trajetória social e profissional. O fato pode estar relacionado com certas características de grandes centros urbanos, como o maior número de habitantes, a forte concorrência, as relações impessoais, o individualismo e a existência de várias alternativas de trabalho e emprego.

Ao contrário do que ocorre nos centros urbanos, nas cidades menores prevalece a maior proximidade entre pessoas e laços de solidariedade mais consolidados. Por exemplo, os "gatos" e empreiteiros selecionam os trabalhadores, tanto para colheita, como para a construção civil pelo critério da indicação de amigos, familiares, ou pessoas conhecidas. Muitas vezes, recorrem aos bairros de periferia conhecidos pelo nome de "Bairro dos Colhedores de Laranja". Em meu estudo, essa é a Vila dos Remédios de uma cidade no interior do Estado de São Paulo. Entre os pescadores, a seleção é realizada pelos mestres de barco, que fazem parte da comunidade e conhecem os pescadores desde crianças. A maioria deles é de filhos ou netos de pescadores. Sendo assim, o principal critério de seleção é a amizade de longa data e, em alguns casos, a indicação de pessoas conhecidas.

Na maioria dos casos analisados em todas as funções, em meu estudo, o tempo na ocupação atual foi de até dez anos. Destacamos como expressivo o número de indivíduos há mais de onze anos na ocupação. Apesar de serem poucos, é importante 
lembrar que alguns estão há mais de 15 anos na tarefa. Nessa perspectiva, o que deveria ser um trabalho provisório ou "bico temporário" até que consigam uma colocação melhor no mercado se tornou a atividade permanente. O tempo na informalidade pode ser maior, se levarmos em conta os subempregos, atividades informais e "bicos" desempenhados antes da ocupação atual.

Percebe-se que houve resistência à inserção no mercado informal por parte dos trabalhadores. A adesão ao trabalho informal não veio logo após a experiência da perda do emprego. Nos casos em que isso ocorreu, o sujeito continuou procurando emprego estável, que pudesse oferecer melhores condições, enquanto realizava algum "bico". Os trabalhadores que possuíam melhor escolaridade e qualificação passaram mais tempo à procura de emprego, na mesma função ou em outra que pagasse o mesmo salário, ou até um valor maior. Alguns aproveitaram para fazer cursos de capacitação profissional em entidades sindicais - cursos de informática e inglês, por exemplo.

HIRATA e HUMPHREY ${ }^{288}$ perceberam que operárias e operários industriais não aderiram imediatamente ao mercado informal após o desemprego vivenciado na década 80. Segundo os autores, é importante dar mais ênfase à trajetória que vai da perda de emprego no setor formal à entrada no setor informal, passando pelo desemprego aberto. Nesse sentido, a definição de "desemprego" deve permitir uma melhor apreensão tanto do desemprego aberto, quanto do desemprego oculto pelo trabalho precário e irregular, ou pelo desalento provocado pelas condições do mercado de trabalho.

HIRATA e HUMPHREY ${ }^{289}$ identificam três fatores como possíveis influências sobre as estratégias operárias face à perda do emprego. Em primeiro lugar, a força da identidade operária, à medida que sua preferência por ocupações específicas, ou tipos

288 HIRATA, H.; HUMPHREY, J. (1989). Trabalhadores Desempregados: trajetórias de operárias e operários industriais no Brasil. RBCS, $n^{\circ}$ 11, vol. 4, outubro, p. $73-74$. 
determinados de emprego pode influenciar a procura por trabalho e a duração de um eventual desemprego. Em segundo lugar, a posição do trabalhador na família pode gerar pressões diferentes sobre a decisão de aceitar ou abandonar um emprego, ou restringir a procura a setores específicos. As pressões recebidas e vivenciadas podem variar segundo o sexo, a posição na família e o tipo de domicílio. Em terceiro lugar, as oportunidades oferecidas aos trabalhadores no mercado de trabalho podem variar consideravelmente de acordo com a qualificação e a experiência.

Os trabalhadores entrevistados de minha pesquisa comentaram que, devido à falta de perspectivas e de oportunidades de emprego, inseriam-se e permaneciam na informalidade, mesmo a contragosto. Todos confirmaram que a inserção no mercado informal aconteceu por não haver opção e alternativa. Relembraram com certo saudosismo a época em que estavam empregados, tinham carteira de trabalho assinada, direitos, salário certo no final do mês, disciplina, rotina e solidariedade maior entre colegas. Quando indagados sobre os conflitos na relação com chefias e patrões, a maioria afirmou que "problemas a gente tem em qualquer trabalho". Destacaram a falta de segurança, estabilidade, perspectiva e direitos no trabalho informal.

As repercussões do desemprego e o tempo de procura por emprego variavam segundo a posição do trabalhador na família. HIRATA e HUMPHREY ${ }^{290}$ perceberam diferenças nos seguintes grupos: casados e solteiros; trabalhadores jovens e trabalhadores experientes; cônjuges e filhos; qualificados e não-qualificados; e mulheres vivendo com ou sem cônjuges. Para os autores, homens e mulheres preferiram empregos assalariados fabris. Mesmo após encontrar novos empregos fora da indústria, continuavam preferindo e procurando o trabalho industrial. Os jovens com pouca

290 HIRATA, H.; HUMPHREY, J. (1989). Trabalhadores Desempregados: trajetórias de operárias e operários industriais no Brasil. RBCS, n 11, vol. 4, outubro, p. $76-77$. 
experiência profissional, após a demissão, orientaram suas vidas ocupacionais para uma nova direção, através de inserção em empregos não-industriais.

HIRATA E HUMPREY ressaltaram que um impedimento para que alguns trabalhadores pudessem realizar suas preferências por empregos regulares era a necessidade de encontrar, a curto prazo, uma fonte de renda alternativa para a família. Neste caso, a maioria dos sujeitos era constituída de cônjuges, ou de filhos. Tanto marido e mulher chefes de família - ou os principais provedores -, quanto filhos que arcavam com a maior parte do orçamento familiar necessitavam encontrar rapidamente outro emprego, ou "bicos". Da mesma maneira, trabalhadores que viviam sós, com irmãos e irmãs, ou com amigos, sem apoio financeiro familiar, tinham pouco tempo para buscar outro trabalho. Em muitos casos, os jovens precisariam procurar novas oportunidades em outras cidades e Estados. Segundo os autores, a pressão sobre os homens casados era agudizada pela composição familiar e pela posição ocupada no seu interior. No caso das esposas não trabalharem, sendo responsabilizadas pelos filhos pequenos, a situação se tornava mais grave. Como não havia mais ninguém no domicílio que pudesse compensar a perda financeira provocada pelo desemprego, os trabalhadores exerciam seu papel de único provedor. Não foi percebida a mesma pressão em relação às esposas que ficavam desempregadas. As mulheres normalmente falavam em trabalhar ou "fazer algum bico" para "ajudar" seus maridos. Mesmo que o dinheiro fosse para pagar aluguel ou comprar comida, elas diziam não ter a obrigação primordial de prover o sustento da família.

HIRATA E HUMPREY ${ }^{291}$ percebem que a qualificação diferencia os operários na procura por outro emprego. Os trabalhadores mais qualificados ocuparam postos de trabalho bem remunerados e tiveram mais tempo de casa. A maior estabilidade

291 HIRATA, H.; HUMPHREY, J. (1989). Trabalhadores Desempregados: trajetórias de operárias e operários industriais no Brasil. RBCS, $\mathrm{n}^{\circ}$ 11, vol. 4, outubro, p. 78 . 
financeira e o fato de receber indenização na rescisão de contrato lhes permitem superar a perda do emprego com maior facilidade e manter o status quo em seus lares. Com melhores perspectivas no mercado do trabalho, é possível para esses trabalhadores se manter em desemprego aberto, sem fazer qualquer "bico" e sem contribuição financeira por parte das mulheres por mais tempo. Já os operários não-qualificados precisam recorrer à atividades não-industriais e "bicos". Os autores ressaltam que mesmo tornando-se trabalhadores por conta-própria, na maioria das vezes essa atividade tem características de um trabalho assalariado subcontratado.

No meu estudo foram observados alguns resultados semelhantes aos de HIRATA e HUMPHREY ${ }^{292}$ no que diz respeito à trajetória ocupacional após o desemprego. Os autores não confirmaram a hipótese de uma entrada maciça dos operários no setor informal como consequência da demissão, defendendo assim a continuidade de uma identidade operária fabril. Podemos relativizar esse resultado, levando-se em conta as transformações ocorridas desde que sua pesquisa foi realizada, na década de 80. Acredito que na década de 90 e nos primeiros anos do decênio seguinte, tal contexto se modificou. Na minha pesquisa, verifica-se que a adesão ao setor informal é realizada com resistências, mas, perante a falta de opções, alternativas e o contexto socioeconômico, os trabalhadores aderem aos trabalhos informais, subempregos e "bicos" em maior quantidade.

Além disso, a maioria dos entrevistados (catadores de materiais recicláveis, colhedores de laranja, vendedores ambulantes e pescadores de lagosta) era de trabalhadores não-qualificados que tinham baixa escolaridade. Dessa forma, número significativo não teve condições financeiras para permanecer por longos períodos à procura de emprego. Os entrevistados disseram não ter tido tempo suficiente para 
buscar algum trabalho em melhores condições, retornar aos estudos, melhorar a qualificação. No início, enquanto desenvolviam "bicos", procuravam emprego. Com o passar do tempo, a iniciativa era deixada de lado devido à dificuldade de reinserção no mercado formal ou, para alguns, ao desestímulo frente às dificuldades e negativas.

Em meu estudo, os trabalhadores que conseguiram reinserção no mercado formal o fizeram em ocupações que não exigiam qualificação, com baixo salário serviços gerais, limpeza e ajudante, entre outros. Nesse caso, a rotatividade era grande. A permanência nos empregos era de curta duração. A saída do emprego ocorria por decisão do próprio trabalhador, quando encontrava oportunidades melhores. De outra maneira, havia os demitidos devido ao enxugamento do quadro de funcionário ou à falência das empresas, na maioria das vezes, terceirizadas.

CARDOSO; COMIN e GUIMARÃES ${ }^{293}$ questionaram a qualificação enquanto medida para assegurar a reinserção do demitido no mesmo mundo das oportunidades ocupacionais mais disputadas, isto é, o setor da indústria química-petroquímica. Segundo os autores, essa realidade era vivida, em média, pela imensa minoria dos indivíduos: apenas um em cada dez trabalhadores desligados da indústria alcançava esse feito. Para os autores, parecia estar ocorrendo um "movimento de dilapidação pura e simples das habilidades e qualificações de contingentes inteiros de trabalhadores, regularmente substituídos por outros".

Esses outros seriam os trabalhadores que se encontravam nas franjas do mercado de trabalho, isto é, "que nunca tiveram experiência de trabalho nessas indústrias" e que estariam mais próximos do conceito clássico de exército industrial de reserva, uma vez que essa indústria seleciona empregados a partir de uma oferta abundante nãoqualificada ou semiqualificada de trabalhadores. Para CARDOSO; COMIN e 
GUIMARÃES, o destino da grande maioria que perde o emprego nas indústrias de ponta sob reestruturação intensa e sistêmica é a exclusão do mercado formal de trabalho ao longo do tempo, talvez o desemprego.

Em meu estudo, os que se encontravam no mercado informal há um longo período diziam que "nem se lembravam mais de quando eram empregados" e que tinham perdido a carteira de trabalho, ou não sabiam onde estava guardada. Entre os catadores de materiais recicláveis, a situação era mais grave, pois vários não tinham qualquer documento. Os trabalhadores, apesar de desejarem um emprego estável, tinham perdido a esperança de conseguir um trabalho regular há muito tempo. Estavam indignados com a situação de precariedade em que se encontravam. Com a falta de perspectivas achavam que a única saída era se conformar com a situação.

Alguns, em seus comentários, davam a entender que a situação em que estavam era uma fatalidade ou obra do destino: "fazer o quê? Agora estou velho e ninguém vai me querer"; "eu não tive sorte mesmo, não pude estudar... Tive que trabalhar cedo... Só sobrou isso pra fazer". Outros se culpavam por estarem nessa situação, arrumando explicações como: "eu não cuidei direito do meu futuro, não quis saber de estudar e agora não tem mais jeito"; "não tive cabeça, gastei todo o dinheiro que recebi (FGTS) num negócio furado... Não pensei direito"; e "eu bebia muito... O alcoolismo me fez perder boas oportunidades". Foram poucos os trabalhadores que relacionavam sua condição de vida e trabalho à crise econômica ou à política do governo. Essas questões pareciam distantes da realidade da maioria.

A falta de planejamento, estratégia e informação levou diversos trabalhadores a ficarem endividados ou perderem todo o dinheiro recebido na demissão. Consideravam, por exemplo, que instituições como o Serviço Brasileiro de Apoio às Micro e Pequenas Empresas (SEBRAE) eram voltadas apenas para que empresários pudessem realizar 
investimentos maiores, por exemplo. Seus empreendimentos tinham sido abertos após consulta a amigos, pessoas conhecidas e familiares. Nenhum dos entrevistados teve qualquer experiência em administração ou gestão de negócios. O sucesso de pequenos empreendedores que se tornam grandes empresários pode ser considerado um mito, pois a realidade é diferente. Metade das pequenas empresas iniciadas por entrevistados fracassou no primeiro ano de existência, por problemas de gestão de negócios.

A maioria dos trabalhadores entrevistados disse que prefere trabalhar com carteira de trabalho assinada. Os argumentos sobre as vantagens da carteira assinada são: "viver com direitos e ser cidadão" (FGTS, férias, décimo terceiro, segurodesemprego, auxílio doença, auxílio acidente de trabalho, convênio médico e aposentadoria, entre outros); "poder contar com o salário no fim do mês"; "ganhar menos que trabalhador por conta-própria, mas ter os direitos"; "ter estabilidade"; e poder planejar com mais tranquilidade as férias, viagens, reforma da casa, compra de automóveis entre outros desejos.

As desvantagens de ser autônomo ou conta-própria tinham a ver com as variações nos preços das mercadorias, conforme a condição financeira e econômica no Brasil e nos países centrais. A instabilidade na economia não permitia planos em longo prazo. Outro problema era a falta de disciplina e conhecimento para controlar o quanto se ganhava e gastava. Um dos vendedores ambulantes comentou que "ser dono de um negócio é bom, mas você terá mais dor de cabeça", no caso de não saber administrar as finanças. Os riscos de fracassar e perder tudo o que foi investido eram grandes. Dessa maneira, muitos trabalhadores comentaram que "gostariam de voltar a ter emprego" e sair da informalidade.

Os vendedores ambulantes ou camelôs costumavam ter prejuízo quando vendiam "fiado" e levavam "calote" dos fregueses. Outro fator de perda de dinheiro era 
ter mercadorias apreendidas pela fiscalização no momento do "rapa". A maioria não tinha reservas para pagar multas e reaver os produtos. Alguns revelaram que dificilmente iriam reaver todos os produtos apreendidos pela prefeitura, pois "sempre ficava faltando alguma coisa”, ou as peças estavam danificadas. Sendo assim, preferiam comprar novas mercadorias "fiadas" com os distribuidores. Alguns tiveram que fazer "bicos" e trabalhar em várias atividades ao mesmo tempo, para manter o negócio funcionando e saldar dívidas.

A pesquisa ECINF 2003 destaca que as principais dificuldades enfrentadas pelos trabalhadores por conta-própria são a falta de clientes, que passam a comprar os mesmos produtos através do crediário nas lojas, e a concorrência muito grande, por causa do aumento no número de pequenos negócios, como por exemplo de vendedores ambulantes. Além disso, a margem de lucro é pequena e a falta de capital próprio e de crédito dificulta o crescimento dos empreendimentos. Esses dados também são constatados em meu estudo. Os vendedores ambulantes ressaltam que têm problemas para obter financiamento e que a solução não passa pela oferta de novas linhas de crédito $^{294}$ (micro crédito e o banco do povo), por conta das altas taxas de juros cobradas, da exigência de comprovação de renda e de critérios para a solicitação de empréstimos.

Segundo a pesquisa ECINF 2003, o grau de organização do negócio é muito reduzido, especialmente em termos de regularização formal. Quase 93\% dos empreendimentos por conta-própria não possuem constituição jurídica. Observa-se uma baixa adesão, em termos de filiação, a organismos que representem interesses coletivos e a sistemas simplificados de registro fiscal. No caso do SIMPLES, por exemplo, menos de $2 \%$ dos microempreendimentos possuíam registros ${ }^{295}$ até 2003.

294 ECINF, IBGE/SEBRAE (2003). 295 ECINF, IBGE/SEBRAE (2003). 
Para POCHMANN ${ }^{296}$, uma das possibilidades de avaliar as dificuldades de operacionalização dos microempreendimentos informais deriva da própria origem do negócio. Grande parte dos empreendimentos, como vimos, surgiu da ausência de alternativa ocupacional, num quadro de desemprego generalizado no país. Por conta disso, mais de $30 \%$ das aberturas de micronegócios não exigiram recursos iniciais. A parte restante contou com recursos próprios (lucros anteriores), herança ou indenização como forma de evitar recursos oriundos de empréstimos bancários.

Outra dificuldade do ponto de vista das empresas seriam os problemas com infraestrutura e instalações físicas, que aumentaram de 1,81\% para 4,13\% no período. Percebe-se que $84 \%$ dos trabalhadores por conta-própria não possuem local próprio de atuação. Trata-se de pequenos negócios informais que operam, em sua maioria, nos locais definidos pelo cliente, nas vias públicas, em veículos ou sem endereço fixo, como no caso dos vendedores ambulantes.

$\mathrm{NERI}^{297}$ comenta que os dados relativos às principais dificuldades apresentadas pelos pequenos negócios, se tomados a valor de fato, indicam a necessidade de implementação de políticas de demanda direcionadas a esses segmentos. Acreditamos que, talvez, tais políticas devam estar menos voltadas a um aumento do poder de compra por parte da população de baixa renda - provavelmente, a principal consumidora dos produtos desses pequenos empreendimentos - , tendo em vista a dificuldade de controle dessa variável pelos gestores de políticas. Defendemos, alternativamente, que os programas estejam mais próximos de um incentivo do governo a uma política de compras públicas destinadas a esse segmento, através das

296 POCHMANN, Marcio (2005). Economia do Microempreendimento Informal no Brasil. Texto para Discussão nº 02. SEBRAE (Serviço Brasileiro de Apoio às Micro e Pequenas Empresas). Brasília/DF.

297 NERI, Marcelo (2005). Análise dos Negócios Nanicos a partir de Pesquisa. Economia Informal Urbana - ECINF. Texto para Discussão, $\mathrm{n}^{\circ} 01$, agosto, 2005, SEBRAE (Serviço Brasileiro de apoio às Micro e Pequenas Empresas). URL: http://www.sebrae.com.br. 
cooperativas, por exemplo, assim estimulando o aumento da demanda local às pequenas empresas $^{298}$.

Para o autor, a longevidade dos empresários informais é um aspecto importante e questionável. Apesar de muitos serem proprietários há mais de cinco anos, é importante ressaltar que os negócios informais sobrevivem por pouco tempo. Nesta perspectiva percebe-se que os empresários informais caracterizam-se por ter "várias vidas", estar sempre passando de negócio para negócio. Os empresários permanecem, mas os empreendimentos mudam - o que indica uma dificuldade para se estabelecerem com garantias de estabilidade. Na pesquisa da ECINF 2003, constatou-se uma concentração dos microempreendimentos com pouco tempo de operação, sendo que $75 \%$ deles possuíam até três anos de existência.

Quanto ao vínculo de trabalho, a ECINF 2003 constata que 60,9\% do total desenvolviam atividades por tempo indeterminado, enquanto $39,1 \%$ trabalhavam por tempo determinado por tarefa ou outras modalidades. Na relação de parentesco com o proprietário do negócio, foi observada alta incidência de laços familiares: 45,3\% dos funcionários eram cônjuges, filhos ou parentes de outro grau, indicando uma presença significativa do negócio familiar.

Segundo a ECINF 2003, dos 10,7 milhões de proprietários do setor informal, apenas 2,54 milhões $(23,8 \%$ do total) contribuíram para a previdência pública (federal, estadual ou municipal). Quanto aos motivos para não contribuir, a razão mais frequente foi o custo elevado, alegado por 41,3\%; em segundo lugar, a falta de conhecimento sobre as regras de aposentadoria, argumento de $14,7 \%$ dos entrevistados; em terceiro lugar, 6,2\% dos entrevistados acham que não vale a pena a remuneração final; por fìm, 
5,4\% disseram não considerar importante a contribuição, constituindo o quarto motivo de maior incidência.

As vantagens de ser autônomo ou conta-própria e assalariado sem carteira de trabalho, para alguns dos entrevistados de meu estudo, eram relacionadas a rendimentos maiores do que tinham os assalariados com carteira assinada. O ganho por produção aparentou ser vantajoso no primeiro momento, pois os autônomos "recebiam tudo o que produziam" e "quanto maior a produção, maior era o que recebiam". Muitos entrevistados relataram a dificuldade de manter a mesma produção após longos anos. O fator idade era importante para ocupações que exigiam muita força física. As variações na economia mundial também afetavam os valores das mercadorias como os produtos vendidos pelos camelôs ou os materiais recicláveis coletados pelos catadores.

Outra vantagem estava no fato de não sofrerem pressões de uma chefia e patrões. Dessa maneira, "trabalhavam a hora que quisessem e quando bem entendessem", acreditavam serem "donos do próprio tempo e da própria vida". Alguns comentaram que não suportavam mais as relações autoritárias e as regras de disciplina na empresa. Um deles desabafou, dizendo que "só de não ter que ouvir chefe falando, criticando e pressionando o tempo todo, era feliz". Os relatos de assédio moral, humilhações e constrangimentos foram vários, principalmente nas situações de reestruturação na empresa e corte de funcionários. A pior situação era quando as empresas decretavam falência e os funcionários saíam sem receber todos os direitos.

Não ter que trabalhar em condições inseguras pra cumprir metas de produtividade e não ter que sofrer pressão de chefia ou patrão foram outras vantagens referidas pelos conta-própria. Alguns entrevistados comentaram que correram risco de morte trabalhando com máquinas defeituosas. Outros tinham sofrido acidentes de trabalho, o que limitou sua capacidade de produção. Por esse motivo, foram 
pressionados a sair da empresa. Essas experiências devem ter sido marcantes na trajetória desses trabalhadores, pois eles foram unânimes ao revelar a "sensação de liberdade e alívio" que sentiam.

Os trabalhadores por conta-própria gostavam da flexibilidade de horário para resolver problemas pessoais, cuidar da casa, dos filhos e de pessoas doentes. Quando precisavam ir ao médico, por exemplo, começavam a trabalhar mais tarde e não precisavam dar satisfação de seus atos para chefias ou patrões. Se o movimento no comércio estivesse fraco, os camelôs decidiam voltar mais cedo para casa. Faziam pausas durante a jornada de trabalho, conforme a própria necessidade. Os catadores de materiais recicláveis costumavam parar a qualquer momento e "tirar um cochilo" quando se sentiam exaustos.

Os assalariados sem carteira de trabalho, pescadores e colhedores de laranja, disseram que a única vantagem de não ter registro era receber um salário mais alto do que aqueles com registro em carteira de trabalho. Os colhedores de laranja reclamaram que o salário havia diminuído em função do registro em carteira havia poucos meses. Na verdade, os empreiteiros e "gatos" descontavam do salário dos funcionários todos os tributos e impostos devidos ao Estado. O mesmo foi dito pelos pescadores de lagosta, que resistiam à formalização do trabalho por temer a diminuição dos rendimentos e a perda do direito ao seguro defeso e a aposentadoria especial.

Todos foram unânimes quanto à importância da carteira de trabalho assinada e nas críticas à redução do salário. Tinham consciência da injustiça existente na relação entre patrão e empregado. Sabia o quanto o empregador lucrava sobre seu trabalho. Ficavam revoltados com a exploração, dizendo: “eles (patrões) ganham cada vez mais e a gente cada vez menos”; “o salário está diminuindo e tudo está mais caro, alimentação, remédio"; e "cada dia a gente está mais pobre". A preferência em ser assalariado sem 
carteira de trabalho e conta-própria era dos aposentados, que se encontravam em situação melhor. O "bico" ajudava a complementar o benefício recebido, no valor de um a dois salários mínimos.

\subsubsection{Organização dos trabalhadores}

Percebe-se que a grande maioria dos trabalhadores nunca teve contato com entidades de classe, movimentos sociais, organizações não-governamentais e cooperativas, nem participou deles. Foram raros os casos em que isso aconteceu. Um número significativo de entrevistados de meu estudo nas áreas urbana e rural disse ter ouvido falar da existência de sindicatos da categoria e movimentos sociais. Mesmo assim, revelaram que não participavam ativamente de movimentos, apesar de apoiar a luta dos trabalhadores. A decisão de não atuar nas organizações era movida pelos seguintes motivos: "falta de interesse"; "falta de tempo"; "falta de conhecimento dos objetivos da ação sindical e dos movimentos sociais"; "descrença na política"; e "achar que política é coisa dos outros e não deles”, entre outros.

Dos entrevistados, alguns pescadores, camelôs e catadores de materiais recicláveis participam ou já participaram de entidades de classe e movimentos sociais. Os participantes de cooperativas (cooperativas de catadores de materiais recicláveis), associações (associações de pessoas com deficiência e associações de cegos) e movimentos sociais (Movimento Unido dos Camelôs do Rio de Janeiro; e Movimento Nacional dos Catadores de Materiais Recicláveis, Movimento Nacional da Pesca) disseram que era fundamental a organização dos trabalhadores, tanto para reivindicar 
questões específicas da categoria, como por motivos socioeconômicos e políticos mais amplos. A maioria dos trabalhadores organizados teve experiência nas indústrias, fábricas e bancos, onde fizeram o primeiro contato com as entidades de classe ou movimentos.

O presidente do Sindicato dos Trabalhadores Informais da Central Única dos Trabalhadores (CUT) comentou a dificuldade de organizar os trabalhadores. Os problemas eram vários: a falta de experiência na ação sindical; a heterogeneidade nas categorias existentes no mercado informal; a diversidade de ocupações e ramos de atividades, entre outras características. A rotatividade entre empregos formais e informais e as mudanças de cidades ou Estados em função de novas ocupações faziam com que os filiados deixassem de atuar na entidade. A maior participação dos trabalhadores na entidade acontecia em ocasiões pontuais, como eleições políticas; proibição de "flanelinhas" e limpadores de vidro de trabalhar nos faróis; intervenção da Guarda Municipal para retirar camelôs de determinadas ruas e apreender mercadorias; e violência contra trabalhadores, entre outras.

Eder Sader ${ }^{299}$ estudou a organização dos movimentos sociais na cidade de São Paulo no período entre os anos 70 e 80 , e identificou os agentes como novos personagens que entravam em cena. Novos, porque eles não se encaixavam nos modelos políticos tradicionais que atuavam na época. Representavam um desejo de conquista de autonomia e liberdades de forma tão legítima, que eles próprios exerciam essa autonomia no cotidiano. Segundo Marilena Chauí, prefaciando a obra de Eder Sader, os novos sujeitos são criados pelos próprios movimentos sociais populares no período: sua prática os põe como sujeitos, sem que teorias prévias os houvessem constituído ou designado $^{300}$.

299 SADER, Eder (1988). Quando novos personagens entraram em cena. São Paulo: Ed. Paz e Terra, 329p. 300 Idem, p. 10. 
Segundo SADER, o saber popular que vinha ganhando força na época era cunhado no contexto em que viviam as pessoas e nos desejos comuns de melhorar as condições de vida. No trabalho, lutavam por liberdade de organização, segurança, salário digno, direito de manifestação, representação sindical e para derrotar o governo burguês. Em casa, principalmente as mulheres rompiam com a tradicional imagem de cuidar da família e se reuniam para discutir os problemas vividos no bairro. Dessas discussões, surgiram o movimento popular de saúde, o movimento contra a carestia e o movimento de moradia, entre outros.

Nessa perspectiva, pode-se entender que os movimentos sociais contemporâneos no Brasil estavam ressurgindo com o vigor de um jovem. Eles tinham muito claros seus objetivos e metas, tinham muita energia nas ações e adotaram um método democrático baseado na reflexão e na ação ${ }^{301}$. Além disso, os movimentos sociais eram constituídos de um coletivo socialmente heterogêneo. Esses movimentos mobilizavam diferentes setores da sociedade, que reivindicavam melhores condições de sobrevivência no espaço urbano. Embora fossem movimentos fragmentados, abrangendo uma população heterogênea, eram fortes e suficientes para garantir uma articulação política.

Em meu estudo, percebe-se por exemplo que a solidariedade entre os vendedores ambulantes se dá principalmente na experiência de trabalho e vida nas ruas, longe das entidades de classe. É o que ocorre no momento do "rapa", fiscalização pela prefeitura e intervenção da Guarda Municipal. Existem os "donos do pedaço" ou "olheiros”, que recebem propina em troca de proteção contra a fiscalização, os ladrões e outros camelôs que não têm espaço na área. Quando é dado o aviso da chegada da fiscalização, o sinal é repassado para todos os vendedores. Os "siris",302 carregam as mercadorias e correm o 
mais rápido possível para se esconder nas ruas paralelas, ou em algum comércio que procure ajudar.

O Movimento Unido dos Camelôs (MUCA), no Rio de Janeiro, conseguiu mobilizar em torno de 2 mil trabalhadores no início dos anos 2000. Realizou várias passeatas e protestos contra a violência da Guarda Municipal e dos fiscais da prefeitura no momento de apreensão das mercadorias e prisão de trabalhadores. Houve inúmeras agressões, que resultaram em sequelas físicas e psíquicas graves e permanentes aos camelôs. Muitos trabalhadores com e sem licenciamento para trabalhar foram presos. Não adiantava recorrer à justiça, pois os ambulantes eram julgados culpados por promover a desordem e vender produtos "piratas", sendo acusados de "ladrões", "criminosos", "muambeiros" e "traficantes".

O Movimento era a favor da regulamentação da profissão, do direito ao trabalho e emprego e contra a violência. Sendo assim, os trabalhadores lutavam por questões que os atingia no dia-a-dia. Um dos camelôs fazia questão de ressaltar o seguinte:

A gente é trabalhador e não ladrão. Ladrão são esses distribuidores que vendem um monte de produto de contrabando. Tem muita gente ganhando dinheiro por detrás disso. Muita grana mesmo. Gente importante que tem proteção. Ganho pra sobreviver, não sou rico que nem eles. É mais fácil mexer com a gente, com eles não. Eles têm muito dinheiro!

Os camelôs faziam referência a grandes empresários que importavam produtos internacionais de maneira ilegal. Questionavam a punição desses contrabandistas em comparação com a violência e perseguição sofridas pelos vendedores no dia-a-dia. Revelavam que a contravenção também era praticada por alguns lojistas que vendiam produtos falsificados ou "piratas" na região. Comentavam que certos comerciantes 
tinham barracas na rua e colocavam um assalariado sem carteira de trabalho para vender mercadorias com valor menor. Nesse caso, não há concorrência entre o comércio formal e informal, mas uma relação de parceria. Aqui percebemos com clareza a não-existência de setores formal e informal. Na verdade, tanto o comércio legal, quanto o ilegal fazem parte do processo de acumulação capitalista ${ }^{303}$.

Os entrevistados não queriam trabalhos precários, instáveis e sem qualquer perspectiva. A maioria aguardava há anos o licenciamento da prefeitura. O termo de permissão estava suspenso por haver um número excessivo de camelôs (regulares e irregulares) nas ruas, segundo os argumentos das autoridades. No momento da pesquisa, analisavam a proposta de transferência para shoppings populares ${ }^{304}$, em lugares distantes dos locais com maior movimento de pessoas. $\mathrm{O}$ valor do aluguel do espaço para vender as mercadorias seria alto em relação ao que recebiam por mês. Preocupavam-se com a localização dos pontos de venda e o aumento da concorrência. Assim, diziam que iam "fugir" dos shoppings e que preferiam vender em outros bairros, longe da repressão.

O MUCA realizava ações conjuntas com outros movimentos populares, como por exemplo os Movimentos de Moradia, dos Trabalhadores Sem Teto, dos Trabalhadores Desempregados, entre outros. Acreditavam que a união entre todos iria fortalecer a luta dos trabalhadores por moradia, saúde, trabalho e emprego. Foi possível encontrar vários vendedores ambulantes e catadores de materiais recicláveis que viviam em situação precária. Costumavam morar na rua, debaixo de viadutos e marquises, ou em casas na periferia da cidade, muito distantes do local de trabalho. Esses trabalhadores participavam de forma conjunta com outras categorias de mobilizações e

303 OLIVEIRA, Francisco de (2003). Crítica à razão dualista. São Paulo: Boitempo Editorial. 304 NEVES, Magda; JAYME, Juliana; ZAMBELLI, Paulina (2006). Trabalho e cidade: os camelôs e a construção dos shoppings populares em Belo Horizonte. Paper apresentado no $30^{\circ}$ Encontro Anual da ANPOCS; Caxambu/Minas Gerais; 24 a 28 de outubro. 
ocupações de prédios do governo, que estavam abandonados no centro da cidade do Rio de Janeiro.

Em minha pesquisa, os catadores de lixo organizados em cooperativas na cidade de São Paulo demonstraram maior interesse na ação política. Alguns tinham participado de reuniões do Movimento dos Catadores de Materiais de Reciclagem e manifestavam apoio à causa. O Movimento Nacional dos Catadores de Materiais Recicláveis (MNCR) buscou a valorização da categoria de catador e defendeu a prática da ação popular contra a exploração capitalista e na luta por uma sociedade mais justa. Defendiam a autogestão no trabalho e o controle da cadeia produtiva da reciclagem, para que assim o serviço dos catadores não fosse utilizado em benefício de "alguns poucos", isto é, dos grandes empresários.

A atividade dos catadores foi sensivelmente prejudicada com a atual crise financeira internacional. Sendo assim, existiu o risco de muitos catadores migrarem para outras atividades informais, como marreteiros e vendedores ambulantes, prejudicando as empresas compradoras desse tipo de material. Segundo o coordenador nacional do $\mathrm{MNCR}^{305}$, “a situação estava crítica em todos os estados. Existia grande quantidade de material parado". Nessa perspectiva, "a renda (dos trabalhadores) havia caído vertiginosamente e as cooperativas estavam com dificuldades para pagar o custo operacional”. Nesta conjuntura, muitas cooperativas corriam riscos de falência.

O coordenador do MNCR comentou que o principal problema era a queda dos preços do quilo de material reciclável. No caso do ferro, em setembro de 2008, o quilo do metal custava $\mathrm{R} \$ 0,42$ e em novembro estava a $\mathrm{R} \$ 0,16$. O papelão baixou $14 \%$, passando de $\mathrm{R} \$ 0,28$ para $\mathrm{R} \$ 0,24$. O plástico coletado baixou, passando de 0,40 para $\mathrm{R}$ \$ 0,30 - redução de 25\%. O alumínio, que estava a $\mathrm{R} \$ 3,40$ em setembro, caiu para $\mathrm{R} \$$

305 Atingidos pela crise, catadores de material reciclável pedem providências. Renda de cooperados caiu drasticamente e organizações podem falir. 21/01/2009. http://www.mncr.org.br. Consulta no dia 09/06/2009. 
2,90 em novembro. Atualmente, os catadores recebem das empresas apenas R $\$ 1,80$ por quilo do alumínio - queda de $47 \%$, com o agravante de que em dezembro sequer houve cota de alumínio, uma vez que não houve comercialização do produto.

Além disso, da mesma maneira que as empresas recebem incentivos fiscais e econômicos dos governos federal, estadual e municipal, o coordenador do MNCR considera que as cooperativas e associações também deveriam receber. As cooperativas são as verdadeiras geradoras de emprego. Estima-se que haja 800 mil catadores de material reciclável no país. A absoluta maioria não tem carteira assinada. Apesar de serem responsáveis por $90 \%$ do processo de reciclagem, pelos cálculos do movimento, os catadores recebem apenas $10 \%$ do lucro resultante desse tipo de comércio. Estima-se que $70 \%$ dos catadores continuam trabalhando nos lixões.

$\mathrm{Na}$ avaliação do coordenador do MNCR, a situação mais grave está no interior, não na capital. A atividade do movimento é mais forte no interior em função da menor oportunidade de trabalho. Outra reclamação do coordenador é que apesar da lei incluir um artigo que dispensa as licitações quando as contratadas são cooperativas ou associações de catadores, a norma não é implementada porque, na prática, os municípios querem contratar empresas. Por outro lado, a contratação de cooperativas e associações evitaria uma crise ainda maior de desemprego. Durante a realização de meu estudo, foi possível perceber o fechamento de várias cooperativas devido à crise financeira mundial. Nesse caso, os catadores procuraram se associar a outras cooperativas em funcionamento; decidiram coletar os materiais recicláveis independentemente de cooperativas; ou mudaram de atividade informal.

$\mathrm{Na}$ pesquisa, perguntei aos membros do Movimento Unidos dos Camelôs (MUCA) e do Movimento Nacional dos Catadores de Materiais Recicláveis o porquê de não unificarem suas lutas, além de simples apoio, com a do Movimento dos 
Desempregados, por exemplo. As lideranças disseram que priorizam a defesa da categoria, seja dos camelôs ou catadores e as soluções para problemas encontrados no cotidiano de trabalho, acima das questões macropolíticas e econômicas que são bandeiras de luta do Movimento dos Trabalhadores Desempregados - a diminuição dos postos de trabalho; a redução dos salários; péssimas condições de trabalho; o combate ao desemprego; ao Estado neoliberal; e à exploração do trabalho no capitalismo; e a desigualdade social, entre outras.

A partir de minha pesquisa, portanto, é possível perceber que uma possibilidade para organizar os trabalhadores informais através dos movimentos sociais, das cooperativas e organizações não-governamentais seria enfocar as lutas em questões relativas à vida cotidiana dos trabalhadores, como fome, moradia, saúde, trabalho e emprego e educação, entre outras. A luta através dos movimentos poderia abarcar inúmeras categorias profissionais, no mercado formal e informal, que estivessem distribuídas em diferentes locais de trabalho e regiões na cidade.

Apesar das reclamações sobre as injustiças, as péssimas condições de trabalho e a exploração, os pescadores, na minha pesquisa, não demonstraram interesse em se organizar politicamente. Consideravam que a situação sempre foi a mesma desde os tempos de seus avós e pais. Não percebiam qualquer perspectiva de mudança e transformação da situação que dependesse de sua iniciativa. Os sindicatos da categoria costumavam estarem presentes nas principais regiões, isto é, onde estava concentrado o maior número de pescadores. Os trabalhadores desse estudo, especificamente, viviam nos pequenos povoados no interior do Ceará onde não existia qualquer tipo de organização. 
A colônia de pescador ${ }^{306}$, lugar de reunião dos associados, onde se esperava encontrar um espaço de discussão, foi referida como entidade que recebe contribuições mensais dos pescadores para fins de aposentadoria (aposentadoria especial) ${ }^{307}$; atestado que comprove o exercício da profissão e cuidado com questões burocráticas do trabalho; e local de lazer. Em nenhum momento, a colônia foi considerada como espaço de organização e mobilização política dos pescadores para fins de reivindicação de melhorias das condições de trabalho e direitos de cidadania, por exemplo.

Em meu estudo, foi constatado que os pescadores de lagosta não participam de nenhuma organização sindical ou movimento social. Alguns dos pescadores de atum são líderes que atuam em organizações sindicais da categoria e movimentos sociais, reconhecendo a importância das entidades. Eles são desempregados da pesca comercial e sobrevivem da pesca artesanal nas regiões de Cabedelo, no interior da Paraíba - como muitos desempregados da pesca, encontram ocupação na pesca artesanal de lagosta e camarão. Reclamam da diferença de condições de trabalho, da falta do vínculo empregatício e de proteção social. O sindicato procura mobilizar os pescadores desempregados para reivindicar emprego, qualificação e educação. Os entrevistados reclamaram da pouca participação dos trabalhadores no sindicato.

Durante a pesquisa, os pescadores citaram a importância do Movimento Nacional dos Pescadores (MONAPE) que nasceu a partir do Movimento da Constituinte da Pesca, iniciado em 1984, considerado um marco que deu visibilidade à categoria e

\footnotetext{
306 Colônia de pescador: agrupamento de pescadores ou agregados associativos que, em troca de mensalidade, tem os seguintes direitos: serviço médico e odontológico; documentação para permissão de pesca; de termo de responsabilidade da embarcação; permissão de pesca no nome de pescador; carteira de pescador profissional; documentação para seguro desemprego na época do defeso; documentação para financiamento do PRONAF - compra de embarcações ou equipamentos de pesca; documentação para aposentadoria, salário maternidade, auxílio doença, contribuição previdenciária (segurado especial ou autônomo na profissão de pescador). A organização elabora contrato de meeiro registrado em cartório para os pescadores, propicia assistência ao pescador carente junto à prefeitura e faz negociação com órgãos responsáveis acerca das reivindicações da classe. 307 Aposentadoria Especial: benefício concedido ao segurado que tenha trabalhado em condições prejudiciais à saúde ou à integridade física. Pata ter direito à aposentadoria especial, o trabalhador deverá comprovar, além do tempo de trabalho, efetiva exposição aos agentes físicos, biológicos ou associações de agentes prejudiciais pelo período exigido para a concessão do benefício (15, 20 ou 25 anos). A comprovação será feita em formulário do Perfil Profissiográfico Previdenciário (PPP), preenchido pela empresa com base em Laudo Técnico de Condições Ambientais de Trabalho (LTCA), expedido por médico do trabalho ou engenheiro de segurança do trabalho (Instituto Nacional de Previdência Social/Ministério da Previdência Social).
} 
alavancou os processos recentes da organização de pescadores ${ }^{308}$. Surgido em decorrência da IV Assembléia Nacional dos pescadores, em 1984, quando pescadores e agentes pastorais vinculados à Comissão Pastoral de Pescadores e outros representantes, discutiram a necessidade de transformação do sistema de representação da categoria ${ }^{309}$. Esse movimento mobilizou pescadores de todo país, visando incluir seus direitos na nova Constituição que estava em elaboração nos anos 80 e questionou justamente a ausência das colônias de pescadores nas lutas da categoria.

O movimento da Constituinte da Pesca procura expandir às Colônias de Pescadores os mesmos princípios que regem os sindicatos urbanos, dentre os quais o direito de livre associação; a não-interferência do poder público; a autonomia; e a unicidade sindical, entre outros, marcando legalmente o fim da tutela sobre as Colônias de Pescadores. O saldo positivo do processo da Constituinte da Pesca foi a emergência de um novo ator social, organizado em torno de propostas políticas elaboradas pelos próprios pescadores e seus organismos de apoio e que esboça uma abrangência nacional. O caminho da conquista e gestão democrática das Colônias de Pescadores é mais tortuoso ${ }^{310}$.

Enquanto pescadores de algumas localidades conquistam suas Colônias e Federações, gerindo-as de acordo com interesses legítimos da categoria ao democratizar os processos eletivos, em outras situações predomina o poder do atraso, com interventores nomeados administrando estes organismos e interesses alheios à categoria indicando seus representantes legais.

\footnotetext{
308 CARDOSO, Eduardo Schiavone (2001). Pescadores Artesanais: natureza, território, movimento social. Tese apresentada junto ao Programa de Pós Graduação em Geografia Física da Faculdade de Filosofia, Letras e Ciências Humanas da Universidade de São Paulo, p. 101- 107. 309 O sistema de representação da categoria compreende a Colônia de Pecadores, as Federações Estaduais e a Confederação Nacional dos Pescadores. Foi criado nos anos de 1920 por iniciativa da Marinha brasileira, tendo por objetivo atrelar os pescadores a este organismo de defesa e prepará-lo para o novo mercado de trabalho que se configurava com a pesca mais moderna e teve ao longo de sua história uma marcada intervenção do Estado brasileiro nas esferas de representação dos pescadores. Cf. CARDOSO, Eduardo Schiavone (2001). 310 CARDOSO, Eduardo Schiavone (2001).p. 104.
} 
Apesar do avanço do Movimento Nacional de Pescadores ${ }^{311}$ nas regiões Norte e Nordeste, existe a dificuldade de articulação das organizações em nível nacional. O direito de livre associação tem servido por vezes para barrar os avanços da categoria. A coexistência de colônias, sindicatos e associações geram atritos na representação legal dos pescadores e interferem diretamente em questões como financiamentos e parcerias, entre outras. Para além dos órgãos de representação profissional, os pescadores buscam a afirmação da categoria a partir de eleições para prefeitos, deputados e vereadores.

Entre os colhedores de laranja, nenhum entrevistado de minha pesquisa participa de organização sindical ou de movimento social. Os trabalhadores comentam que "não entendem de política" e consideram a luta sindical um "problema dos outros". Os colhedores que têm experiência na indústria e no comércio comentam que sabem da existência dos sindicatos, mas que nunca tiveram interesse em participar. Alguns tiveram experiência em cooperativas, mas não bem-sucedida. Na verdade, trabalham em "coopergatos", isto é, empresas que camuflam o subemprego, o trabalho temporário e a intermediação de mão-de-obra irregular. Nesse sentido, não querem formar cooperativas e não acreditam nessa iniciativa.

Apesar das resistências e da pouca adesão às entidades de representação profissional é possível perceber que o papel dos sindicatos e dos movimentos sociais é fundamental para a organização dessa categoria de trabalhadores, que se encontra na informalidade. Com o aumento crescente de desemprego rural e urbano e a presença expressiva de trabalhadores informais, as entidades de classe precisam urgentemente voltar sua atenção a esse problema.

Apesar de alguns entrevistados, de meu estudo, demonstrarem desconfiança em relação aos políticos em geral, elogiaram as ações do presidente da República e o

311 Em 1996, o Movimento Nacional de Pescadores, trabalhava diretamente com 99 Colônias e quatro Sindicatos de Pescadores, mantendo contato com outras 23 Colônias e 37 Associações e apoiando 42 grupos de oposição para conquista de novas Colônias. Dados do próprio movimento, em 1996, apontam para a existência de cerca de 400 Colônias de Pescadores no país. Cf. CARDOSO, Eduardo Schiavone (2001).p. 106. 
Programa Bolsa Família - mesmo considerando o valor do auxílio irrisório. Havia identificação com Lula por ele ter sido "trabalhador" e "peão" e conseguido vencer na vida. Os entrevistados disseram que as condições econômicas melhoraram, apesar de ainda não estarem em nível satisfatório. A maioria dos colhedores de laranja, vendedores ambulantes e pescadores tinha em suas casas os seguintes equipamentos: televisão, geladeira, freezer e aparelho de som, entre outros. Entre os camelôs e colhedores de laranja, alguns possuíam automóveis ou motocicletas.

Um número expressivo de pescadores, colhedores de laranja, catadores de materiais recicláveis e vendedores ambulantes frequentava entidades religiosas regularmente. Eles acreditavam que a única maneira de ter saúde, emprego, alimentação, "teto para viver" e esperança de futuro melhor era através da fé em Deus.

As redes sociais formadas por amigos, familiares, vizinhança, igrejas e Organizações Não-Governamentais (ONGs), muitas vezes, cumpriam o papel do Estado, prestando assistência social. Por exemplo, notou-se que as igrejas e ONGs forneciam alimentos, roupas, remédios, cursos profissionalizantes e orientação psicológica para os necessitados. Os amigos, familiares e pessoas conhecidas os apoiavam nos momentos de desemprego. Procuravam arrumar empregos, trabalhos temporários, "bicos" e emprestavam dinheiro. A ação política era substituída pelo assistencialismo. Nesse caso, o Estado neoliberal, o modelo financeiro internacional, o modelo de capitalismo existente, que seriam as principais causas da situação de desigualdade e pobreza pareciam problemas distantes dos trabalhadores e deixavam de ser combatidos. 


\subsubsection{Identidades e trabalho informal}

As condições de trabalho na informalidade possuem várias especificidades. Considerando-se essas diferenças, procurei analisar os processos de construção de identidades dos trabalhadores entrevistados em meu estudo. Os diversos espaços de trabalho, nas ruas das cidades, no mar e no campo, oferecem muitas oportunidades para que os indivíduos construam suas identidades. Sendo assim, é possível afirmar que a categoria profissional tem proeminência no processo de análise das formas de identificação, na medida em que elas se tornam referências para as maneiras de abordar e compreender o trabalhador.

Mais do que a categoria profissional, procurei ressaltar as condições de trabalho, ou seja, aquelas nas quais o trabalhador desempenha sua atividade. As condições encontradas no cotidiano de trabalho dos pescadores de lagosta, colhedores de laranja, vendedores ambulantes e catadores de materiais recicláveis na informalidade articulam aspectos com os quais os entrevistados se identificam, através dos quais encontram possibilidades de construir identidades profissionais em que se reconheçam.

Em primeiro lugar, as condições oferecidas no trabalho formal surgem como contraponto para as condições encontradas na informalidade. Dessa maneira, podemos dizer que a identidade construída na informalidade se opõe à identidade do trabalhador formal, com suas condições de vida e trabalho.

Faz-se necessário destacar que, segundo enfatizaram os entrevistados, a precarização não é uma exclusividade da informalidade, mas também está presente no trabalho formal. Em alguns casos, a partir dos relatos coletados ficou evidente que as condições mais precárias estavam justamente nos empregos formais nas empresas, 
indústrias e serviços. Apesar de considerar importante chamar a atenção a este aspecto, não pretendo entrar na polêmica de quais condições são piores, se no trabalho formal ou informal. Na verdade, os trabalhadores colocam em primeiro lugar a importância dos direitos trabalhistas e previdenciários, que em nossa sociedade são pactuados através do contrato legal de trabalho, no caso a carteira de trabalho assinada.

Apesar de alguns trabalhadores criarem uma identificação maior com a informalidade - pela flexibilidade de horário, autonomia, por não terem chefe ou patrão, ganharem o quanto produzem e por terem rendimentos maiores - , percebe-se que a maioria desenvolve atividades informais por falta de alternativa. Conforme revelado pelos próprios entrevistados, eles tentaram uma inserção ou reinserção no mercado formal durante longo período e, após inúmeras tentativas sem resultados positivos, acabaram permanecendo no mercado informal. A maioria dos sujeitos teve experiência como terceirizados e temporários. Nesses casos, apesar de possuírem contrato assinado, reclamaram das péssimas condições de trabalho. Foi a partir dessas experiências que alguns decidiram ser autônomos ou conta-própria.

Alguns entrevistados chegaram a trabalhar como terceirizados e temporários em grandes empresas. Esses trabalhadores reclamaram do tratamento diferenciado em relação aos empregados diretos. Relataram que, apesar de desenvolverem as mesmas atividades, recebiam salários menores, sem os mesmos benefícios, e utilizavam uniformes, refeitórios e vestiários diferentes. Nessas condições, sentiam-se humilhados e desrespeitados. Sempre mantiveram a esperança de serem contratados. Após experiências em diversos locais de trabalho e sem quaisquer perspectivas de se tornarem empregados efetivos, preferiram abrir negócios próprios.

Em relação à informalidade, os catadores de materiais recicláveis e parte dos vendedores ambulantes se definem como "autônomos" ou por "conta-própria". Os 
colhedores de laranja, pescadores de lagosta e outra parte dos vendedores ambulantes se apresentam como "empregados", mesmo não sendo assalariados com carteira de trabalho assinada: afirmam ser "empregados" dos "donos" de barracas e carrinhos de cachorro-quente e sorvetes; "gatos"; "empreiteiros"; e "donos" de barcos, por exemplo. Ser "empregado" significa estar trabalhando para outra pessoa. Questionados sobre a carteira de trabalho assinada, lembram imediatamente que na verdade são "empregados sem carteira" e "empregados sem nenhum direito".

Nessa perspectiva, nota-se a importância dada à carteira de trabalho pelo trabalhador. O registro em carteira significa "ser trabalhador digno de direitos" - o que oferece status superior ao indivíduo. Por outro lado, o trabalhador critica o fato do salário ser menor para os assalariados com carteira assinada. É comum encontrar entre eles acusações contra o patrão, por tirar do salário do empregado o valor dos tributos e impostos. Essa situação foi observada entre os colhedores de laranja e pescadores de lagosta, que estavam em processo de formalização do trabalho na época da pesquisa de campo.

Os pescadores, por exemplo, costumavam "fugir" ou evitar o contato com os auditores do trabalho no momento da fiscalização. A resistência estava relacionada ao medo de represália por parte dos donos de barcos, das ameaças de corte ou desemprego, no caso dos formalizados, de redução do salário e de perda do direito ao segurodesemprego no período de defeso. Esses trabalhadores sabiam que sairiam perdendo, pois os armadores (donos de barcos) não aceitariam diminuir seu lucro. Esse fato foi observado nas intervenções de 2008 e 2009 em alguns municípios no interior do Ceará. No depoimento de um auditor fiscal, foi possível perceber que a situação piorou no intervalo de um ano. Não era apenas o dono de barco que se escondia da físcalização, 
mas os pescadores também evitavam o contato, por temer represálias e consequências mais graves.

Parte dos colhedores de laranja também estava insatisfeita com a formalização e planejava mudar de profissão no futuro. O salário baixo e trabalho desgastante fazia com que os trabalhadores buscassem outras alternativas para a sobrevivência. Desejavam trabalhar por conta-própria, como vendedores ambulantes; catadores de material de reciclagem; montadores e vendedores de bijuterias; doceiras; ou abrir um pequeno negócio, por exemplo um bar; loja de consertos; loja de material para construção civil; e loja de roupas usadas, entre outros estabelecimentos.

Foi percebida menor resistência à formalização entre os colhedores de laranja do que entre os pescadores de lagosta. Existe a hipótese de que a maior organização dos trabalhadores da agricultura e a fiscalização mais intensiva na região Sudeste tenha contribuído para o aumento no número de carteiras registradas no campo.

A maioria dos entrevistados tem baixa escolaridade e poucas possibilidades de buscar outras inserções no mercado de trabalho, em funções com maior status e salários mais altos. Sendo assim, costumam mudar de ocupações na informalidade. Foi observado que as trajetórias "incertas" ou "despadronizadas", as mudanças constantes de ocupações e as inúmeras inserções e reinserções no mercado formal fazem com que sejam construídas novas identidades de trabalhador. A identidade de operário de fábrica e indústria, por exemplo, é algo distante da realidade dos trabalhadores que estão há anos na informalidade, como mostraram as entrevistas realizadas ao longo de minha pesquisa.

A nova identidade profissional tem a característica de ser principalmente mutável ou múltipla, devido ao desemprego recorrente e ao fato da inserção ocupacional duradoura ser rara Nessa situação, os trabalhadores podem "estar" ou "ser" catador; 
colhedor; pescador; vendedor; pedreiro; motorista; faxineiro; diarista; manicure; empregado doméstico; jardineiro ou vigia, para citar algumas ocupações. Vários entrevistados revelaram desenvolver mais de uma atividade de trabalho ao mesmo tempo, dependendo da necessidade financeira, das oportunidades e, no caso dos pescadores, devido ao período de proibição da pesca (defeso). Para eles, uma atividade é considerada principal e as demais, "bicos". Os entrevistados escolhem como principal ocupação aquela que proporciona maiores rendimentos, sendo que os outros trabalhos ajudam a complementar a renda.

Foram encontrados vendedores ambulantes que fazem faxina, costuram e preparam doces e salgados por encomenda nas horas vagas. Os catadores de materiais recicláveis fazem "bicos" como vigias, seguranças e faxineiros, e aproveitam a carroça para transportar mudanças de vez em quando. Já os colhedores de laranja aproveitam os períodos de menor produção ou os finais de semana para trabalhar nos barracões, separando e encaixotando laranjas e enxertando mudas. Alguns montam bijuterias para lojas da cidade ou para vender; coletam materiais recicláveis nas ruas; e aproveitam os períodos de festas e maior movimento de público para virar camelôs. No período de defeso, parte significativa dos pescadores trabalha na construção civil, agricultura e pecuária.

Os trabalhadores na maturidade ou velhice fazem questão de destacar o fato de serem aposentados, seja por tempo de trabalho, ou idade. A maioria comentou que continua trabalhando por motivos financeiros, já que os benefícios recebidos têm valor baixo, e alguns preferem trabalhar para ter alguma ocupação ao invés de ficar em casa assistindo à televisão e dormindo o tempo todo e, principalmente, para manter sua rede de sociabilidade. Sendo assim, a primeira resposta para a questão sobre como se 
autodefinem profissionalmente é "aposentado". A atividade informal desenvolvida é considerada um "bico", ou trabalho eventual ou temporário.

Nessa perspectiva, percebe-se que a luta pela sobrevivência e o desemprego fez com que trabalhadores, antes ferramenteiros; carpinteiros; prensistas; eletricistas; bancários; microempresários; proprietários de lojas, bares e lanchonetes, se tornassem mão-de-obra de baixo custo; trabalhadores informais; e trabalhadores com vínculos atípicos e precários. Nota-se a dificuldade de construir uma "identidade profissional" numa trajetória "incerta" e "instável”, repleta de mudanças de vínculos empregatícios, entradas e saídas do mercado formal e experiências de longo prazo no mercado informal, entre outros contextos. Talvez seja possível falar em "identidades sociais e profissionais" no caso dos trabalhadores na informalidade.

As experiências em diferentes atividades informais após o desemprego fazem com que os trabalhadores sintam aptos para desempenhar várias funções. As atividades informais não exigem qualificação e alta escolaridade. É comum ouvir as seguintes falas: "a gente é pau prá toda obra"; "a gente se vira como pode"; "eu já fiz de tudo um pouco. Só não roubei ou matei"; "eu sou um homem honesto e trabalhador"; e "estou sempre procurando alguma coisa prá fazer... Não posso ficar parado, preciso pagar as contas e levar comida prá família". Alguns entrevistados atribuem a culpa pela situação à política de governo e à economia mundial. Outros costumam responsabilizar a si mesmos pela situação em que se encontram. Muitos catadores de materiais recicláveis e camelôs procuram esconder sua atividade de trabalho de familiares e amigos.

A partir dessas falas, foi possível perceber o peso da moral na construção da identidade desses sujeitos. O ser trabalhador está diretamente relacionado com a noção de honestidade, dignidade, esforço para conseguir arcar com seu sustento, mesmo tendo que se submeter a trabalhos penosos e degradantes. Nesse sentido, o trabalho serve para 
"garantir o sustento" e "ganhar o pão de cada dia" para continuar trabalhando. A identidade se refere a um "indivíduo que vive do e para o trabalho". Em nenhum momento, algum trabalhador disse sentir orgulho de ser vendedor ambulante, catador de lixo, colhedor de laranja ou pescador de lagosta. Apesar de sentirem prazer na profissão e gostarem do que fazem, foi percebido que os trabalhadores não se identificam totalmente com a profissão. A identificação profissional é mais comum entre os pescadores e colhedores de laranja.

Os catadores de materiais recicláveis e vendedores ambulantes são os que mais reclamam da maneira como são identificados pelos outros na sociedade. A construção da identidade social na trajetória dos trabalhadores é permeada por mudanças significativas. Os catadores foram denominados de "catadores de lixo" no passado e passaram a ser chamados de "catadores de materiais recicláveis" há poucos anos. A maioria fazia questão de corrigir a pesquisadora, ressaltando que não coletam lixo, mas materiais recicláveis. Durantes as entrevistas, comentavam que se sentiam importantes, pois limpavam as ruas das cidades e ajudavam a preservar o meio ambiente, contribuindo para a reciclagem dos produtos. Não aceitavam a ser chamados de “carroceiros", pois esses eram aqueles que utilizavam cavalos para puxar a carroça.

Serem chamados de "catadores de materiais recicláveis" é motivo de orgulho e satisfação. Por outro lado, tais trabalhadores relataram que também sofrem preconceito e discriminação. Percebe-se neste caso uma identidade deteriorada e o estigma contra os sujeitos devido ao trabalho desenvolvido. Os catadores disseram ser comum ouvirem o público em geral chamá-los dos seguintes nomes: "mendigos"; "maloqueiros"; "nóias"; "ladrões"; "bêbados"; "vagabundos"; "sujos"; "fedidos"; e "nojentos". Dificilmente são vistos e respeitados como trabalhadores. Ter de escutar xingamentos e humilhações por "atrapalhar o trânsito" foi uma reclamação comum a todos entrevistados. Eles têm 
consciência de que incomodam os motoristas, mas ao mesmo tempo, sentem-se no direito de ocupar as ruas, pois estão tentando "ganhar o pão" como qualquer outro trabalhador.

Manifestam o medo de serem atropelados e agredidos pelos motoristas mais apressados. Dizem sentir-se "invisíveis" enquanto pessoas e seres humanos na sociedade. Reclamam da indiferença e dos maus tratos. Por outro lado, a maioria reconhece a existência de pessoas solidárias como, por exemplo, quem lhes dá alimentos, roupas e calçados, ou paga uma refeição, e gentis, que dão passagem para o catador mudar de faixa numa avenida, ou esperando o trabalhador atravessar a rua puxando a carroça. A maior satisfação de cada catador entrevistado é "ser respeitado como gente", receber atenção, ser visto, poder falar e principalmente ser ouvido pelos diferentes.

As principais maneiras de se referir a si mesmos encontradas junto aos catadores foram: ser "trabalhador" e "honesto". Todos foram unânimes em dizer que se consideram úteis, batalhadores, defensores da natureza e que se sentem indignados com as acusações de "maloqueiros"; "nóias"; “sujos”; "porcos”; “nojentos”; “vagabundos”; e "bagunceiros". Um dos entrevistados considera os catadores como heróis ou "guerreiros dos materiais recicláveis". A maioria sente orgulho da profissão, pois contribuem para preservar o meio ambiente e deixar a cidade limpa ao coletar materiais recicláveis. Apesar disso, muitos preferem não revelar a familiares o trabalho que exercem por causa da discriminação e do preconceito.

Estas denominações pejorativas se devem ao fato de lidarem com o lixo, que simbolicamente significa algo negativo, não aceitável, repulsivo e imprestável, entre outros sentidos atribuídos socialmente. Além disso, os catadores são discriminados por deixarem as calçadas sujas com restos de lixo não-reciclável no momento da coleta. Os 
entrevistados se justificavam, dizendo que existem ladrões no meio, mas que a maioria é trabalhadora e luta pela sobrevivência. Disseram que se fossem ladrões, não estariam puxando a carroça pesada o dia inteiro. Da mesma maneira, muitos catadores fazem questão de varrer as calçadas ou organizar os lixos não-recicláveis para manter o ambiente o mais limpo possível.

Alguns trabalhadores fizeram comparações entre profissões. Comentaram que, antes, como camelôs, eram tratados como "ladrões" pela Guarda Civil e o fiscal da prefeitura. Tinham suas mercadorias apreendidas, perderam o dinheiro investido várias vezes e viviam fugindo feito "bandidos". Agora como catadores, se consideram mais bem tratados, pelo menos conseguem trabalhar de maneira mais tranquila. Existe um projeto de lei ${ }^{312}$ que regulamenta a profissão de catador de lixo e incentiva a coleta seletiva de materiais recicláveis, a participação dos trabalhadores em cooperativas com o objetivo de organizar a categoria e de inclusão social.

Apesar disso, um número expressivo de catadores permanece trabalhando de maneira isolada nas ruas. As carroças costumam atrapalhar o trânsito intenso nas cidades. Mesmo assim, existe uma convivência pacífica entre os trabalhadores e a Guarda Municipal. Um aspecto importante é que os catadores não negociam mercadorias contrabandeadas, sem impostos e nem artigos "piratas". Nessa perspectiva, os catadores se consideram honestos, enquanto os camelôs são vistos como "ladrões" e “contrabandistas". Percebe-se conotação moral no discurso sobre as ocupações. O trabalho não é apenas meio de sobrevivência, mas cumpre papel importante na construção da identidade profissional dos sujeitos.

312312 O Projeto de Lei 5649/05 prevê a regulamentação da profissão de coletor, catador e reciclador de lixo. O PL estabelece as funções das atividades relacionadas, assim como seus direitos e deveres trabalhistas e previdenciários.O catador de material reciclável deve trabalhar em regime autônomo, com registro em Delegacias Regionais de Trabalho ou nos órgãos públicos conveniados. A atividade deve ser vista como o primeiro elo da reciclagem de materiais. O objetivo é transformar os catadores em recicladores. As cooperativas têm papel fundamental na organização dos trabalhadores e no armazenamento dos materiais coletados. O projeto coloca o trabalho de reciclagem de lixo como atividade insalubre, o que dá aos empregados das centrais o direito a benefícios trabalhistas e previdenciários. Além disso, prevê a instalação de escolas de ensino fundamental próximas às centrais de reciclagem para atender os profissionais e suas famílias. O Projeto de Lei 5649/05 foi rejeitado no dia $1^{\circ}$ de dezembro de 2008. O PL tramitava em caráter conclusivo e a proposta foi arquivada. http://noticias.ambientalbrasil.com.br e http://www.direitos.com.br. Consulta realizada no dia 2 de setembro de 2009. 
A profissão de vendedor ambulante ou camelô era bem vista no passado, pois os indivíduos levavam as mercadorias até as casas das pessoas, poupando-as do incomodo de irem até as lojas e comércios. Hoje temos uma variedade de produtos que podemos comprar via internet e receber em casa pelo correio ou serviço de entrega. Assim, os vendedores ambulantes passam a ser vistos como "camelôs" que vendem produtos com preços menores, "produtos genéricos" para não dizer "piratas", "falsificados". Muitos camelôs fazem questão de ressaltar que vendem apenas produtos alimentícios ou de baixo valor, como material escolar; roupas; cosméticos; e bijuterias, entre outros. Destacam a diferença em relação aos produtos eletrônicos e de valor mais alto, vendidos por exemplo nos shoppings da Rua 25 de Março.

Os grandes contrabandistas são considerados "ladrões", "bandidos" e sonegadores. Em nenhum momento os ambulantes fazem referência ao fato de também estarem comercializando produtos sem pagar qualquer imposto ou tributo. Quando indagados, dizem ser "pequenos comerciantes" que recebem pouco, sem condições de arcar com essas despesas. Na verdade, a maioria não percebe que faz parte da cadeia de produção e distribuição de produtos falsificados e vendidos sem impostos. A situação não é confortável, na maior parte dos casos, à medida que os entrevistados afirmam que prefeririam ser assalariados com carteira, pois teriam salário certo no final do mês, férias e os demais direitos garantidos.

No passado, os colhedores de laranja eram considerados os "sabiás na lavoura", por ficarem de pé sobre os degraus de escadas encostadas nas árvores no momento da colheita. Antes, os trabalhadores nasciam, cresciam e trabalhavam a vida toda na zona rural. Eram verdadeiramente caipiras, roceiros e lavradores. Hoje a realidade é diferente. Os colhedores tornaram-se “bóias-frias”. São moradores das cidades próximas à região de plantação e colheita, que saem da cidade para trabalhar na lavoura. Mesmo 
tendo nascido e passado parte da infância na roça, vivem nas áreas urbanas há muito tempo. Sendo assim, não é raro levarem hábitos e costumes da cidade para a lavoura.

Os "sabiás da lavoura" são coisa do passado que não existe mais. Agora, os "bóias-frias" trabalham na plantação e colheita da laranja; mandioca; milho; café; e cana-de-açúcar, entre outros produtos. A maioria teve experiência em indústrias, serviços e comércios. Entendo o trabalho na colheita como uma oportunidade de emprego. A maior preocupação nas lavouras é o consumo de drogas, como o crack e a maconha, pelos trabalhadores. Esse fato contribui para alterar a identidade dos indivíduos e traz preocupação, como se pode observar na fala de um colhedor: "tem gente que fuma crack prá ter pique e produzir mais... Aí começam a dizer que somos uns 'drogados' e 'viciados'. Isso não existia antes”. O mesmo acontece no corte da cana-de-açúcar, segundo outro colhedor de laranja que já trabalhou na lavoura da cana.

Os pescadores de lagosta foram considerados verdadeiros "heróis do mar", que com sua coragem desafiavam as tempestades, os perigos do oceano e as situações de trabalho precárias. Faziam isso para conseguir peixes e crustáceos considerados alimentos nutritivos e valiosos. As proezas desses trabalhadores foram contadas em canções populares em várias regiões no mundo. Infelizmente, hoje em dia é possível notar o fenômeno do consumo de drogas durante a atividade de trabalho também entre os pescadores. O fato não é comentado abertamente na comunidade, apesar de ser do conhecimento de todos. Dessa maneira, em paralelo à imagem de "heróis" e "corajosos", os pescadores passaram ser considerados como "drogados" e pessoas desajustadas.

Existe um conflito entre os pescadores de barco e os pescadores mergulhadores. Esses últimos são acusados de destruir o meio ambiente no mar e colocar a própria vida 
em risco realizando a pesca predatória, além de ameaçar de morte os pescadores de barco em caso de denúncia aos órgãos responsáveis.

A pesca da lagosta através do mergulho é realizada sem qualquer procedimento de segurança, o que provoca mortes por descompressão. Mesmo sendo proibida por lei, os pescadores mergulhadores continuam arriscando a vida para conseguir o maior número de lagostas no menor tempo possível, sem respeitar as lagostas pequenas. A pesca de barco, diferentemente da de mergulho, utiliza "covos" e armadilhas", que procuram retirar somente as lagostas maiores. A utilização da rede de caçoeira na pesca de mergulho é muito criticada, pois danifica a fauna e flora marinha.

Essa forma, os mergulhadores são identificados como "criminosos" e "bandidos", sendo também reconhecidos como "destruidores" e "depredadores" da fauna marinha por não respeitar o regulamento da pesca.

Os trabalhadores informais formam um grupo heterogêneo. Em meu estudo, procurei fechar foco nos trabalhadores por conta-própria e assalariados sem carteira, entre outros. Houve a preocupação com aqueles que não têm direitos trabalhistas garantidos em carteira de trabalho. Nas trajetórias sociais e na análise das biografias, foi possível perceber a existência de várias formas de identidade. Os trabalhadores na informalidade não podem ser definidos apenas por uma ocupação, pois é comum trabalharem em mais de uma atividade. Na tentativa de pensar a identidade à partir da ocupação principal, notou-se que os aspectos positivos e negativos fazem parte da construção social da identidade profissional.

A maioria dos entrevistados não apresenta uma identificação total com a atividade informal. A inserção e permanência ocorrem por falta de oportunidades e a identificação pode acontecer pelas vantagens de não ter pressão de chefias; pela possibilidade de obter maiores rendimentos; e pela flexibilidade de horários. Mesmo 
assim, um número expressivo de trabalhadores informais de baixa escolaridade, caso dos entrevistados em minha pesquisa, revelou que preferiria ter um emprego estável. Esse desejo existe mesmo entre aqueles que estão há muitos anos na informalidade. Atualmente, com a instabilidade econômica, a falta de experiência em gestão e a forte possibilidade de fracasso nos negócios, ser trabalhador autônomo ou por conta-própria é sinal de problemas e dificuldades. Esses aspectos dificultam a formação de uma identidade para os sujeitos enquadrados na situação de trabalhadores informais.

\subsection{Condição das mulheres}

A participação feminina no mercado de trabalho teve crescimento a partir da década de 70. Para Bruschini ${ }^{313}$, esse fenômeno podia ser considerado como "uma das mais marcantes transformações sociais ocorridas no país". O crescimento ocorreu num contexto de expansão econômica e aceleração dos processos de industrialização e urbanização. $\mathrm{O}$ aumento da participação feminina no mercado de trabalho continuou na década de 80, apesar da redução da atividade econômica e do aumento do desemprego.

No início dos anos 80, após adotar uma série de práticas neoliberais, o país passou por importantes mudanças em sua organização política e econômica. A crise associada à dívida externa, os planos de ajuste econômico e as restrições de gastos públicos com a esfera social levaram à precarização do mercado de trabalho e ao aumento da exclusão social. Durante a década de 80 , a força de trabalho do setor 
industrial se transferia para o setor terciário. Segundo Bruschini ${ }^{314}$, os principais setores responsáveis pela geração emprego foram a prestação de serviços; o comércio e as atividades sociais; administração pública. Os postos de trabalho fechados na indústria foram substituídos pelos abertos pelos setores de comércio e serviços. A maioria desses postos tinha as seguintes características: trabalho informal, baixa produtividade e salários menores do que os pagos pela indústria.

Nesse contexto, os anos 90 se caracterizaram pela abertura econômica, pela redução de investimentos na esfera social, pela terceirização da economia e pelo crescimento contínuo na inserção da mulher no mercado de trabalho. A reestruturação econômica e produtiva provocou a flexibilização das relações de trabalho e a perda de ocupações no setor formal. Nessa perspectiva, as trabalhadoras brasileiras passaram a representar 43,5\% da força de trabalho em 2005 , frente a 40,4\% em $1995^{315}$.

A primeira questão a destacar é a intensidade e a constância do crescimento da atividade feminina. Nesse caso, os indicadores para o Brasil revelam que no período de 1995 a 2005, a População Economicamente Ativa (PEA) ${ }^{316}$ feminina passou de 28 para 41,7 milhões, a taxa de atividade aumentou de $47 \%$ para $53 \%$ e a porcentagem de mulheres no conjunto de trabalhadores subiu de $40,4 \%$ para $43,5 \%$. Isso significa que mais da metade da população feminina em idade ativa trabalhou ou procurou trabalho em 2005 e que mais de 40 em cada 100 trabalhadores eram do sexo feminino, na mesma data. No entanto, apesar do considerável avanço verificado no período, as mulheres

\footnotetext{
314 Idem (2000). "Gênero e trabalho no Brasil: novas conquistas ou persistência da dominação?"(Brasil, 1985/95). In: ROCHA, M. I. B. (org.). Trabalho e gênero: mudanças, permanências e desafios. São Paulo: Abep, Nepo/Unicamp, Cedeplar/UFMG, Editora 34, p. 13-58.

315 Em 2005, a população economicamente ativa (PEA) somava 96 milhões de pessoas na condição de ocupada e desocupada. Deste contingente 56,4\% eram homens e 43,6\% eram mulheres. Instituto Brasileiro de Geografia e Estatística (IBGE). Síntese de Indicadores Sociais 2006. Estudos \& Pesquisas - Informação Demográfica e Socioeconômica, $\mathrm{n}^{\circ}$ 19, Rio de Janeiro, 2006.

316 Segundo classificação do Instituto Brasileiro de Geografia e Estatística (IBGE) - que realiza o Censo Demográfico, as Pesquisas Domiciliares anuais e outras pesquisas oficiais -, a População Economicamente Ativa inclui os ocupados e os desocupados, com 10 anos ou mais de idade, no mercado de trabalho.. Os ocupados são aqueles que estão empregados, no setor formal ou no informal, enquanto os desocupados são aqueles à procura de emprego na ocasião da pesquisa. Já a População Economicamente Inativa inclui os aposentados, os que estão em asilos, os estudantes, os que vivem de renda e os/as que cuidam de afazeres domésticos.
} 
ainda estavam longe de atingir as taxas masculinas de atividade, superiores a 70\%, e o número de ocupados ou de empregados ${ }^{317}$ do sexo masculino.

Havia mais mulheres que homens no setor de serviços, particularmente no comércio. Nesse setor, era verificada maior flexibilização das relações de trabalho, com perda de empregos formais e aumento de atividades informais e precárias. Apesar da forte presença das mulheres, o desemprego feminino era maior que o masculino, principalmente entre mulheres com baixa escolaridade. A partir de 1996, devido à reestruturação do setor de serviços e à inovação tecnológica, percebeu-se maior demanda por mão-de-obra qualificada e com maior escolaridade. As mulheres com escolaridade alta sofriam relativamente mais com o desemprego que os homens no mesmo nível, porém essa taxa era menor que a das mulheres com baixa escolaridade. Para mulheres com escolaridade e qualificação baixas, restavam trabalhos informais, mal remunerados, vulneráveis e precários.

Apesar da crescente inserção das mulheres no mercado de trabalho, as mesmas têm sido especialmente atingidas pelo desemprego em todo o mundo. Desde meados dos anos 90, verificam-se maiores taxas de desemprego feminino do que masculino. Um dos fatores que podem contribuir para esse resultado é a precarização das condições de trabalho. As trabalhadoras costumam receber os piores salários, são vítimas de contratos parciais e temporários e as mais atingidas pelo subemprego e trabalho informal. Para Bruschini $^{318}$, o nível de ganhos dos trabalhadores e trabalhadoras do Brasil é reconhecidamente baixo, sendo que as mulheres brasileiras - como as de todo o mundo - ganham ainda menos do que os homens.

317 A denominação "empregados" inclui: empregados com carteira assinada, sem carteira assinada, sem declaração de carteira, militares e funcionários públicos estatutários. Não inclui empregados domésticos. 
Segundo a autora, a evolução da distribuição do rendimento do trabalho ${ }^{319}$ dos brasileiros de ambos os sexos no período de 1993 a 2005 é indicada por um aumento das proporções de trabalhadores(as) com menores rendimentos, refletindo uma queda nos ganhos advindos do trabalho da população ocupada: se em 1993, 48\% dos homens recebiam até dois salários mínimos, em 2005 essa porcentagem passou a ser de 58\%; quanto às mulheres, os índices encontrados foram 55\% em 1993 e 63\% em 2005, sendo que nesta data $36 \%$ das trabalhadoras auferiam rendimentos inferiores a um salário mínimo. Posso considerar que o aumento no número de pessoas com salários baixos; isto é, até dois salários mínimos, pode estar relacionado com o aumento na taxa de população economicamente ativa (PEA).

É necessário adicionar mais um elemento à análise: muita coisa continua igual, à medida que as mulheres permanecem como as principais responsáveis pelas atividades domésticas e cuidados com os filhos e demais familiares, o que representa uma sobrecarga para aquelas que também realizam atividades econômicas. A permanência da responsabilidade feminina pelos afazeres domésticos e cuidados com outras pessoas indica a continuidade de modelos familiares tradicionais, que superexploram as trabalhadoras, sobretudo as que são mães de filhos pequenos ${ }^{320}$.

A questão da divisão sexual do trabalho foi discutida intensamente por várias autoras. Hirata ${ }^{321}$ assinala que "a divisão social e técnica do trabalho é duplicada em uma hierarquia clara do ponto de vista de relações sexuais de poder. A divisão sexual do trabalho é indissociável das relações sociais do sexo (gênero), que são relações de

319 Segundo a Pesquisa Mensal de Emprego, referente a seis regiões metropolitanas (Recife, Salvador, Belo Horizonte, Rio de Janeiro, São Paulo e Porto Alegre), o rendimento médio habitual das mulheres em janeiro de 2008 foi de R\$ 956,80, enquanto que o dos homens foi de R\$ 1.342,70, A partir desses valores, verificase que as mulheres receberam $71,3 \%$ do rendimento dos homens. Para as mulheres que possuíam nível superior completo o rendimento médio habitual foi de R\$ 2.291,80 em janeiro de 2008; enquanto para os homens esse valor foi de R $\$ 3.841,40$. Assim, comparando trabalhadores que possuíam o nível superior, observouse que o rendimento das mulheres é cerca de $60 \%$ do rendimento dos homens, indicando que, mesmo com grau de escolaridade mais elevado, as discrepâncias salariais entre homens e mulheres seguem elevadas. Instituto Brasileiro de Geografia e Estatística (IBGE) (2008). Algumas características da inserção das mulheres no mercado de trabalho -Recife, Salvador, Belo Horizonte, Rio de Janeiro, São Paulo e Porto Alegre- 2003 - 2008. Pesquisa Mensal de Emprego, Rio de Janeiro, pp.15-16

320 Ibidem.

321 HIRATA, H. (2002). Nova divisão sexual do trabalho? Um olhar voltado para a empresa e a sociedade. São Paulo: Boitempo, Coleção Mundo do Trabalho. 
desigualdade, hierarquia, assimetria e antagonismo". A organização da força de trabalho revela uma assimetria sexual que corresponde a uma divisão institucional entre as esferas de atividade doméstica e pública, segundo a autora. Nessa perspectiva, às mulheres compete administrar a casa, as crianças, ou seja, uma vida construída em torno da reprodução, dos laços afetivos e familiares. Aos homens compete um dia-a-dia relacionado à coletividade, ao trabalho. Nessa relação doméstico-público, as atividades públicas são mais valorizadas do que as domésticas, em decorrência de um reconhecimento que as associa diretamente à geração de valor.

Hirata $^{322}$ comenta que um dos paradoxos da globalização é que o aumento do emprego remunerado vem acompanhado pela precarização e vulnerabilidade crescente. Pode-se dizer que as desigualdades de salários, de condições de trabalho e de saúde não diminuíram e que a divisão do trabalho doméstico não se modificou substancialmente, a despeito de um maior envolvimento nas responsabilidades profissionais por parte das mulheres. Nessa perspectiva, a globalização representou novas oportunidades, mas também novos riscos para as mulheres trabalhadoras. Para a autora, as desigualdades sociais nas relações de trabalho e saúde parecem ter piorado sob o impacto das políticas de flexibilização.

Hirata $^{323}$ também destaca que, nos países do Norte, predomina o modelo do trabalho formal em tempo parcial, ocupado majoritariamente por mulheres que recebem salários parciais - o que agrava as disparidades existentes na repartição do trabalho doméstico no interior do casal. Nos países do Sul, países em desenvolvimento, o trabalho flexível assume a figura de trabalho informal, sem nenhuma proteção social. Também nesta categoria, as mulheres estão maciçamente representadas, sendo que os dois casos, tempo parcial e trabalho informal, constituem ocupações frequentemente

322 Idem (2001/02). "Globalização e divisão sexual do trabalho". Cadernos Pagu, n. 17/18, pp. 139-156, p. 144 323 Ibidem, p. 145. 
instáveis, mal remuneradas, com uma possibilidade quase inexistente de formação, promoção e carreira e direitos sociais limitados ou inexistentes - em especial no que diz respeito aos empregos fora do setor público e particularmente no comércio e nos serviços.

Até a década de 70, na divisão sexual do trabalho, as mulheres costumavam inserir-se nas profissões relacionadas à educação, saúde, serviços sociais, serviços de limpeza, serviços domésticos, comércio e agricultura, principalmente na produção agrícola para próprio consumo. Hoje a realidade é outra, sendo possível encontrar mulheres em ocupações na construção civil; coleta de lixo; segurança e polícia; limpeza pública; indústria de transformação; mineração; transporte público e de carga; correios; entrega de produtos utilizando motos; agricultura e pecuária comercial e industrial, entre outras. Frente ao desemprego e por falta de opção, as trabalhadoras com pouca escolaridade e qualificação se submetem às ocupações precárias, aos vínculos atípicos, ao trabalho informal, sem proteção social, mal remunerado e à sobrecarga de trabalho.

Neste estudo, a maioria dos trabalhadores informais entrevistados é do sexo masculino, tanto nas ocupações no campo, quanto no mar e na cidade. Ao todo foram entrevistadas apenas dezesseis mulheres. Podemos supor que a predominância masculina ocorre devido ao uso da força física no desempenho das atividades de trabalho; ao horário extensivo; à exposição ao risco de violência, entre outros motivos. Por outro lado, apesar das ocupações estudadas serem tradicionalmente masculinas, percebe-se o aumento significativo da força de trabalho feminina nessas atividades, mantendo-se, contudo, a permanência das desigualdades.

Embora maioria nas ocupações estudadas, os homens ainda são exclusivos apenas na pesca da lagosta. A explicação encontrada é a necessidade de permanecerem confinados em barcos sem infra-estrutura durante longo período e o trabalho pesado, 
que exige esforço físico contínuo, praticamente sem pausa. Nesse caso, a presença de mulheres seria inconveniente para o desenvolvimento da tarefa. Por outro lado, é importante lembrar que a existência de mulheres na pesca artesanal sempre foi significativa, principalmente nas regiões Norte e Nordeste.

Ao longo desta pesquisa, as pescadoras puderam ser vistas por exemplo em embarcações pequenas nos rios, em busca de peixes; nos mangues de onde tiravam caranguejos; no mar sobre jangadas, puxando redes com camarões junto a outros pescadores, ou mergulhando para pegar lagostas. Utilizavam métodos rudimentares e pouca tecnologia no trabalho. A produção era para o sustento próprio ou da família e, em muitas situações, para o comércio informal. As trabalhadoras costumavam ser acompanhadas por seus filhos durante o trabalho e o barco era seu instrumento de trabalho e local de moradia, em alguns casos.

As colhedoras de laranja, catadoras de materiais recicláveis e vendedoras ambulantes entrevistadas cumpriam jornada de trabalho prolongada em função das atividades dentro e fora de casa. Todas foram unânimes nas queixas quanto à necessidade de obter renda para o sustento da família, cuidar dos afazeres da casa, dar atenção aos filhos, maridos, companheiros e pessoas agregadas e à ausência de proteção social. Não eram raros os casos de violência contra a mulher e abandono. Quando aconteciam, em geral as crianças permaneciam com as mães e nem sempre recebiam pensão alimentícia.

Além disso, todas sentiam revolta e ressentimento pelo trabalho doméstico não ser reconhecido e valorizado. Disseram que "sempre foi assim" e que tinham aprendido desde crianças, com as avós e mães, a serem responsáveis pelos afazeres domésticos, como se fosse parte da natureza da mulher. As entrevistadas percebiam que essa tendência começava antes mesmo da mulher constituir família: já na posição de filhas, 
sentiam o peso das tarefas domésticas, especialmente quando provenientes de famílias de baixa renda. Também tinham o costume de assumir a responsabilidade pelos deveres e, muitas vezes, pela criação dos próprios irmãos, enquanto a mãe estava no mercado de trabalho.

Outro ponto evidenciado nas entrevistas é que essas mulheres gostavam de trabalhar fora de casa para ganhar o próprio dinheiro e fugir da opressão dos maridos. Quanto a isso, reclamavam que além de dividir os gastos, tinham que realizar os afazeres domésticos. Ressaltavam o excesso de trabalho e acúmulo de tarefas dentro e fora de casa, além da já citada falta de valorização e prestígio do trabalho doméstico.

HIRATA comenta que o movimento feminista no início da década de 70 tornou "evidente" que "uma enorme massa de trabalho era efetuada gratuitamente pelas mulheres, que esse trabalho era invisível e não reconhecido, que era realizado não para elas mesmas, mas para outros, e sempre em nome da natureza, do amor e do dever materno" 324 . Nessa perspectiva, os "afazeres domésticos" deixavam de ser vistos como trabalho não-remunerado, isto é, como atividade econômica não-remunerada. Esse fato demonstra a superexploração a que as mulheres estavam sujeitas.

Para as entrevistadas dessa pesquisa, a relação entre trabalho doméstico e trabalho fora de casa não significava conciliação de atividades, mas acúmulo excessivo de funções, tensões e conflitos para as trabalhadoras. Além da questão da sobrecarga de trabalho, percebeu-se que a qualificação, a escolaridade, a ascensão profissional, o estresse, o sofrimento psíquico e o pouco tempo para cuidar de si própria foram alguns dos aspectos relacionados à questão de gênero e trabalho observados. Apesar das limitações financeiras, da falta de infra-estrutura, como creches e pessoas para auxiliar no trabalho doméstico, existia o desejo de voltar a estudar, melhorar a qualificação e 
conseguir um trabalho decente: mais bem remunerado, menos penoso, menos perigoso e menos pesado.

Muitas eram chefes de família ou as únicas provedoras, pois estavam separadas, divorciadas, solteiras, viúvas, ou os maridos se encontravam desempregados, impossibilitados de trabalhar por motivo de doença ou acidente. Outras dividiam as despesas da casa. Os casos em que a mulher trabalhava para complementar minimamente a renda do marido ou companheiro eram raros. $\mathrm{Na}$ amostra, não havia nenhuma trabalhadora aposentada por tempo de trabalho. Esse fato confirma a existência de uma trajetória profissional irregular, que consiste na mudança constante de ocupações no mercado informal e formal. Foi possível encontrar trabalhadoras que nunca haviam sido assalariadas com registro em carteira, mesmo estando há muito tempo no mercado de trabalho.

A trajetória ocupacional era marcada pela inserção no mercado de trabalho em ocupações que exigiam pouca ou nenhuma escolaridade. No início da trajetória ocupacional, trabalhavam para ajudar a família na lavoura e pecuária; como empregadas domésticas; lavadeiras; cozinheiras; cuidadoras; babás; costureiras; e em serviços gerais no comércio e indústrias, entre outras atividades. Recebiam no máximo um salário mínimo. Várias tiveram experiências em trabalhos sem remuneração. Recebiam alimentos, roupas, lugar para moradia e auxílio para pagar dívidas contraídas pela família.

Algumas trabalhadoras, em meu estudo, que conseguiram completar o ensino fundamental e até o médio tiveram experiência no trabalho fabril e industrial por certo tempo, mas em funções que não exigiam qualificação profissional, como ajudantes e nos serviços gerais, por exemplo. A maioria recebia entre um e dois salários e poucas ganhavam até três salários mínimos. As entrevistadas que trabalharam nas indústrias 
foram demitidas na década de 90, devido à crise econômica e à reestruturações internas nas empresas. Após a demissão, tentaram reinserção em outras indústrias por algum período. Foram obrigadas a aceitar trabalhos temporários, "bicos" no comércio e serviços por falta de opção. Algumas conseguiram ser assalariadas com carteira nos setores de Serviço e Comércio, mas disseram que preferiam o trabalho nas indústrias pelos direitos e garantias recebidas.

O mesmo fenômeno foi observado no estudo de Guimarães que analisou a mobilidade de trabalhadores demitidos pelas indústrias na década de 90. Esses trabalhadores foram rastreados durante nove anos sucessivos e alguns desses sujeitos jamais restabeleceram um novo vínculo de trabalho formal (trabalho registrado em carteira) com todos os direitos usuais de seguridade social e com a "âncora da sustentação em organizações sindicais. A autora relatou que entre os demitidos $41 \%$ jamais conseguiram constituir vínculo formal nos 8 anos subseqüentes de trabalho. Entre os homens essa proporção se reduzia para $37 \%$ e entre as mulheres ela se elevava para $48 \%{ }^{325}$. Esses dados confirmam a maior dificuldade das mulheres conseguirem empregos com vínculos formais e consequentemente são inseridas em trabalhos precários.

A dupla ou tripla jornada de trabalho era aceita sob protestos. As trabalhadoras criticavam a falta de solidariedade dos parceiros; o não-pagamento de pensão alimentícia pelos pais; a necessidade de muitas vezes deixar os filhos pequenos sozinhos em casa, enquanto trabalhavam durante a maior parte do dia; e a falta de tempo para cuidar da educação das crianças. A maioria se preocupava com a frequência das crianças nas escolas e com as dificuldades para comparecer às reuniões, ou quando a direção da instituição solicitava a presença dos pais. Outro ponto crítico era a 
necessidade de faltar ao trabalho quando algum filho adoecia e necessitava de seus cuidados.

\subsubsection{Trabalhadoras e trabalhadores do campo}

No campo, isto é, nas chácaras e fazendas na região de Limeira no interior do Estado de São Paulo a presença de crianças na plantação estava proibida pelos "gatos" ou "turmeiros" devido aos riscos de acidentes e por acharem que os pequenos podiam atrapalhar o desenvolvimento do trabalho na colheita. $\mathrm{O}$ trabalho no campo tem suas regras e disciplina e em alguns aspectos se aproxima do modelo fabril. Não vimos filhos brincando na plantação, ou ajudando seus pais na colheita, como acontecia no passado quando o trabalho era familiar. Hoje, o conhecimento não era transmitido de pai para filho, como entre os "velhos colhedores". Entre esses, muitos têm apenas 30 e poucos anos e trabalham na lavoura desde os 12 anos ou menos. Alguns dos "novos colhedores" tinham mais de 40 anos e haviam sido expulsos da colheita da cana-deaçúcar e demitidos das indústrias de transformação por não conseguirem mais atingir as metas de produção, cada vez maiores.

Quando a pesquisadora visitou as colhedoras de laranja em suas casas nos finais de semana, percebeu que o ritmo de trabalho continuava intenso e que sobrava pouco tempo para o descanso. Elas se encontravam lavando e passando roupa, limpando a casa, cozinhando, cuidando dos filhos ou fazendo algum "bico", por exemplo, montando bijuterias para as indústrias e vendendo lingeries ou produtos de beleza para aumentar a renda. Ao indagar se elas usavam os produtos, responderam que sim, 
principalmente quando iam à igreja. Comentaram que raramente saíam para visitar familiares e amigos, passear ou namorar, por falta de tempo.

A questão da violência doméstica ou agressão física e moral contra mulher foi relatada por algumas colhedoras de laranja e catadoras de materiais recicláveis. Elas comentaram que nos finais de semana os namorados, companheiros ou maridos costumavam ficar nos bares, bebendo cerveja com os amigos. Quando voltavam para casa em estado de consciência alterado, respondiam com violência física e verbal a qualquer contrariedade. Uma das trabalhadoras disse o seguinte:

\section{Maria:}

Eu prefiro ficar na roça trabalhando. Todo sábado e domingo é a mesma coisa. Meu marido que é pedreiro. Ele volta pra casa só para dormir e brigar. Ele passa o dia nos bares enchendo a cara. Tem dia que eu tenho que ir pegar ele pois não volta sozinho pra casa. Fica caindo nas ruas de tanto beber. Aqui vira um inferno. Começa a discutir, reclamar de tudo e bate em mim. De tanto apanhar já ameacei largar ele, ir pra polícia... Mas tenho medo. Ele faz ameaça que vai me matar... Tenho meus filhos pequenos ainda e preciso do dinheiro dele em casa. Isto me deixa triste e desgostosa da vida mas não tem jeito...

Os "turmeiros" comentaram que havia menos mulheres na colheita, mas que a quantidade vinha aumentando dia após dia. O mesmo caso era observado entre os pescadores e catadores de materiais recicláveis. Entre os vendedores ambulantes, a quantidade de homens e mulheres era praticamente igual. Algumas trabalhadoras eram quase tão produtivas quanto os homens, apesar da exigência de força física para carregar sacolas de 40 quilos, cheias de laranjas, várias vezes ao dia; puxar carroças de até 500 
quilos; e pescar camarões e lagostas com rede de arrastão, o que também é trabalho pesado.

Essa não era, no entanto, a regra: a maioria das trabalhadoras produzia menos que os homens e consequentemente tinha rendimentos menores. As colhedoras conseguiam preencher e carregar menos sacolas de laranja, por terem menor força física. As catadoras carregavam materiais de menor peso e valor nas carroças. Tanto as catadoras, quanto vendedoras ambulantes trabalhavam menos horas por causa dos cuidados com os filhos e a casa. No trabalho da pesca, por exemplo a da lagosta e camarão, quando realizada em grupo a produção era dividida de maneira igualitária. De qualquer forma, na maioria das vezes, as pescadoras trabalhavam sozinhas, tinham produção menor que os homens e jornada de trabalho reduzida em função do trabalho doméstico.

O mercado de trabalho agrícola costuma incorporar homens e rejeitar mulheres, sob os argumentos da força física. Por outro lado, existe o reconhecimento de que as mulheres possuem habilidades e qualificações muito úteis na produção de frutas para consumidores exigentes, situados, muitas vezes, nos países do norte ${ }^{326}$. Apesar do reconhecimento, percebeu-se durante a pesquisa que as mulheres acabavam realizando trabalhos mais precários, principalmente atividades repetitivas, consideradas mais "leves" e menos valorizadas. Enquanto isso, os homens ficavam com os trabalhos que aparentemente exigiam competência técnica e qualificação.

Para os "turmeiros" e "gatos", as colhedoras eram mais disciplinadas, "dóceis", obedientes, caprichosas, pacientes, dedicadas, atenciosas e reclamavam menos do trabalho. Não se recusavam, como alguns homens, a fazer o "trabalho mais puxado" e o "trabalho pesado", como carregar o caminhão com laranjas no final do dia, depois de 
uma jornada longa e exaustiva, para receber R\$ 200 a mais no salário. Para a maioria dos homens, o tamanho do esforço exigido nessa tarefa não compensava o ganho. As mulheres aceitavam a tarefa, pois já recebiam menos pela produção na colheita da laranja.

A divisão sexual no trabalho rural ficou evidente no caso da colheita da laranja. A maioria das mulheres trabalhava nos barracões, fazendo enxerto de mudas ou separando laranja nas esteiras. Esse trabalho era considerado "leve". Porém, percebeuse que o ritmo de trabalho era intenso, que elas não possuíam pausas para descanso, ficavam em pé o tempo todo, precisavam prestar atenção contínua na esteira para zelar pela qualidade das frutas para exportação e indústria de suco, faziam trabalho repetitivo e preparavam centenas de enxertos de mudas em pouco tempo. As atividades eram supervisionadas e os produtos passavam por um controle de qualidade rigoroso. $\mathrm{O}$ salário era menos da metade daquele recebido na colheita. Além disso, as trabalhadoras rurais eram responsáveis, muitas vezes, pela pulverização de agrotóxicos nas plantações e aplicação de adubos na terra. Dessa maneira, corriam risco de lesões por esforços repetitivos e lombalgias, além da contaminação por agentes químicos que poderia resultar em mortes, doenças respiratórias e alergias, entre outras decorrências.

Nos barracões, era possível encontrar alguns homens vítimas de acidente de trabalho, lesionados, com deficiência e idosos, entre outros excluídos das atividades na plantação e colheita de gêneros como laranja, cana de açúcar, mandioca e milho. Para os poucos homens que faziam trabalho pesado no barracão, como carregar o caminhão com caixas de laranja, essa ocupação era temporária: esperavam encontrar emprego na colheita, onde era possível ganhar mais pela produção e ficar livre da supervisão ostensiva de chefias e patrões. 


\subsubsection{Catadoras e catadores}

$\mathrm{Na}$ cidade, algumas das catadoras entrevistadas precisavam levar seus filhos pequenos para trabalhar, colocando em risco a vida das crianças por causa dos acidentes de trânsito, atropelamentos, quedas e ferimentos causados pelo contato com materiais recicláveis, quando colocadas dentro da carroça. Eram moradoras de rua e necessitavam trabalhar das 7 às 22 horas. Ressaltavam que não tinham com quem deixar as crianças e que o acesso a creches da prefeitura era impossível com uma carga horária de trabalho tão extensa. Precisavam alimentar, trocar as fraldas, dar banho e colocar os filhos para repousar na rua. Uma das entrevistadas relatou que teve sua carroça roubada enquanto comprava fraldas com suas duas meninas em uma farmácia. Disse que não era a primeira vez que passava por isso e expressou o desespero de conseguir dinheiro para comprar outra. Não podia ficar parada, pois tinha que sustentar sozinha as crianças.

O número de mulheres catadoras tem aumentado a cada dia com o desemprego e a falta de opção profissional. Mesmo assim, é menor que o dos homens catadores. As trabalhadoras costumam percorrer ruas movimentadas, com trânsito intenso e ladeiras em vários bairros na cidade, durante um longo período do dia. O peso da carroça com materiais recicláveis varia de 300 a 500 quilos.

Uma primeira observação é que a atividade exige muita força e resistência física. Fica a indagação de como as mulheres, em alguns casos grávidas, conseguem executar a tarefa. As entrevistadas disseram coletar materiais recicláveis mais leves, como papel, papelão, plástico e latinhas de alumínio, entre outros. Em relação ao peso da carroça, comentaram que estavam acostumadas e que não tinham outra maneira de sobreviver. 
As grávidas e as mais idosas sentiam maior limitação e procuravam diminuir a jornada de trabalho.

As trabalhadoras estavam expostas a todos os tipos de violência. Entre as mulheres entrevistadas, a maioria havia sido vítima de estupro várias vezes. O assunto é delicado e difícil de ser revelado durante a entrevista. Existia um misto de vergonha, revolta e tristeza. Ao procurarem ajuda policial, passavam por situações constrangedoras, pois acabavam sendo culpadas pelo acontecimento. Era comum ouvir que "lugar de mulher é em casa e não na rua", que "mulher que vive na rua é vagabunda", ou agressões como "arruma um macho para te proteger", entre outras, verbais e morais.

As mulheres que sofreram abuso sexual disseram ser comum entre as catadoras. Em primeiro lugar, a atividade é solitária, pesada, executada na rua, onde a trabalhadora fica exposta à situação de miséria, pobreza e violência, expressa por atropelamentos, tentativas de homicídio, agressões físicas e morais e estupros, para citar algumas ocorrências cotidianas. Durante o trabalho, todas as entrevistadas passavam por humilhações e insultos que feriam sua identidade feminina, sendo chamadas de "burra de carga", "puta", "vagabunda" e "vadia", além de outras denominações discriminatórias, pelos passantes.

No período da noite, aumenta o perigo e o medo da violência. Algumas entrevistadas se arriscavam a dormir isoladas na rua, contando apenas com a sorte. Tinham que mudar de lugar constantemente para não ficarem marcadas pelos agressores. Quando procuravam se aproximar de um catador ou grupo, na maioria dos casos praticavam sexo em troca proteção. Era comum terem vários parceiros sexuais, correndo o risco de serem vítimas de doenças infectocontagiosas e de gravidez 
indesejada. Entre as poucas mulheres entrevistadas, uma era portadora de HIV e outra, de sífilis. Citaremos abaixo o relato de duas catadoras:

\section{Eneralda:}

Na rua só têm "nóia". Eu mesma já fui drogada. Vivia louca para esquecer dos problemas da vida. Olha passei muito sufoco e sofrimento. Só de lembrar minha pressão sobe... Vou te contar uma coisinha só: por causa de um ponto de coleta de lixo, comprei uma briga feia na rua. Foi "bate-boca", baixaria mesmo. Uma noite, estava dormindo quando fui atacada por um homem. Levei duas facadas na barriga (a entrevistada mostra as cicatrizes para a pesquisadora). O macho da outra, da mulher que eu briguei por causa do lixo, foi se vingar. Fui socorrida pelo carro da polícia e levada ao Hospital rápido. Perdi sangue. Pensei que fosse morrer. Fiquei internada um bom tempo, pois tive outras complicações. Nunca mais dormi sossegada. Mudava de lugar, ficava acordada, dormia pouco. Sentia medo de tudo. Aí tomava mais droga ainda (fumava crack, cocaína, maconha) e bebia prá espantar o medo. O problema era ter que trabalhar cedo no dia seguinte. Eu não via a hora de amanhecer, porque durante o dia é menos perigoso. Tomo vários remédios que o psiquiatra receitou até hoje. Nunca mais fiquei boa da cabeça. Outra coisa foi que peguei foi sífilis e faço tratamento direto. $\mathrm{Na}$ rua, a gente dorme com um, com outro (silêncio). Sabe tem outra coisa que dói o peito só de pensar. Eu já fui atacada várias vezes (sofreu abuso sexual). Uma vez foi durante o dia... imagina! Estava descansando debaixo da carroça depois do almoço... tirando cochilo e um cara me dominou com uma faca no meu pescoço. Não podia fazer nada. Já me machucaram feio e parei no hospital... Sinto vergonha. Parece que a gente é nada! É esse pessoal "nóia" que mora rua que faz maldades. Sei de muitas histórias por aí com outras mulheres. Hoje estou bem, apesar de ficar triste, pois tenho dois filhos perdidos no mundo 
(depois a trabalhadora contou que estão presos por roubo e homicídio). Saí da rua, estou na cooperativa, tenho meu cantinho (alugou um apartamento que divide com colegas carroceiros) e luto pra virar a página. Esquecer tudo que passei... Adoro forró, samba nos finais de semana... Estar viva é mais importante.

\section{Dina:}

"Eu tive quatro filhos e estou esperando o quinto. Estou no oitavo mês de gravidez. Ainda puxo carroça pesando 300 a 400 quilos. Estou bem e o bebê também. Os dois mais velhos, tiraram de mim. O juizado levou. Eles foram pra adoção. Os outros dois estão com uma irmã minha. Eu gosto da rua... de trabalhar sozinha... por conta. Só vim para o albergue por causa da gravidez. Eles estão me ajudando. Estou indo ao médico, faço acompanhamento. Estou fazendo o enxoval do bebê com o que ganho do pessoal da igreja e dos outros moradores do albergue. Quero ver se consigo ficar com este filho. Vou cuidar bem...

A assistência social do albergue em que a entrevistada residia comentou que Dina, de apenas 27 anos, tinha sido casada apenas uma vez. O marido, pai de seus dois filhos mais velhos, foi assassinado por causa do tráfico de drogas. Ela disse desconhecer os pais dos outros dois. Ficou grávida mantendo relações sexuais com vários parceiros.

Devido ao abandono e aos maus tratos, perdeu a guarda dos filhos mais velhos, já adotados. A irmã ameaçava devolver à Dina os outros filhos a qualquer momento. Disse que as crianças davam muito trabalho, que faltava dinheiro e tinha muitos problemas pessoais. A catadora procurava enviar uma quantia mínima mensalmente para ajudar no sustento das crianças. Tinha receio de que esses filhos também fossem para a adoção, caso a tia não quisesse criar. A trabalhadora repetiu várias vezes que tinha medo de perder as crianças para o juizado. 
O filho que a catadora esperava, na ocasião dessa pesquisa, era de um homem casado, comprador e vendedor de peças roubadas, como relógios, celulares, jóias e notebooks, entre outras. O pai disse que não assumiria a criança e que ajudaria com dinheiro quando fosse possível. A assistente social estava tentando sensibilizar Dina a ficar com os filhos que estava sob os cuidados da tia e o bebê que estava para nascer, sair da rua e alugar um imóvel para reunir a família. Ela acreditava que seria uma saída para a trabalhadora reconstruir sua vida de maneira saudável, com o acompanhamento da assistência social da igreja ou do próprio albergue ${ }^{327}$. O dinheiro que Dina conseguia receber com a venda dos materiais recicláveis era suficiente para alugar um barraco ou quarto de pensão. Os alimentos seriam doados por instituições de caridade.

$\mathrm{Na}$ maioria dos casos, as mulheres tinham perdido seus laços familiares. Os filhos viviam com parentes, muitas vezes em lugares distantes, que dificultavam o contato. O modo de vida na rua não era adequado para crianças, era outro lugar e outro mundo. A separação entre a rua e a casa deveria ser respeitada, mas o distanciamento, mesmo involuntário, fazia com que perdessem o vínculo. As catadoras tinham vários filhos, mas preferiam não falar deles. A maioria mantinha certos segredos sobre a situação familiar e seu trabalho - e isso vale para ambos os sexos. Como exemplo da relação dos e das catadoras com seu trabalho, dois entrevistados disseram que quando visitavam os filhos vestiam a melhor roupa, guardada em lugar seguro na casa de algum conhecido e nunca revelavam a profissão, pois sentiam vergonha e humilhação.

Para algumas mulheres, era melhor "deixar pra lá" os filhos e "fazer de conta que não existiam". As lembranças traziam a dor da saudade e o sentimento de impotência, por não poder cuidar e conviver com eles. Em alguns casos, os filhos não reconheciam as catadoras/es como mãe ou pai, pois tinham sido criados pelas avós, tias

327 Albergue Bom Bosco, no Bom Retiro - São Paulo. 
e parentes. Em outros casos, os jovens tomaram rumos incertos, se "perderam na vida", isto é, estavam presos, foragidos, ou simplesmente desapareceram e não deram mais notícia. A aflição maior era saber se estavam vivos ou mortos.

Percebeu-se que a desintegração familiar era comum entre esses sujeitos. A maioria dos catadores era solitária e de poucos amigos. $\mathrm{O}$ ambiente de violência na rua suscitava desconfiança e medo. As interações sociais eram circunstanciais para proteção durante a noite, diversão no bar ou no forró nos finais de semana e para organizar uma cooperativa, como no caso dos moradores de um albergue de carroceiros. O contato com familiares era inexistente ou esporádico. Uma catadora que morava na rua comentou o seguinte:

\section{Luzia}

Meu marido me abandonou e foi ficar com outra. Ainda me roubou a carroça. Eu já tive várias carroças roubadas. Sempre compro outra. Eu moro neste pedaço há um bom tempo (há um ano). Cada hora fico num canto, no canteiro, na pracinha, na rua. Os guardas acham ruim, mas viram que não adianta. Eu não saio daqui. O pessoal que trabalha na região me ajuda muito. Eu me sinto muito só, por isto tenho muitos cachorros. Adoro os animais. Eles estão sempre comigo e fazem companhia. Tenho cinco filhos... tudo homem. Estão espalhados por aí. Eu nem sei o que estão fazendo da vida. Eles não me procuram e eu também não procuro. Só tem um menino que aparece aqui de vez em quando. Ele é bom filho, direito, trabalhador. Quer que eu saia da rua, mas eu não vou querer. Imagina morar na casa dele com a mulher dele? Aí não, não dá certo. Eu gosto de ficar aqui mesmo no meu canto, do meu jeito. 


\subsubsection{Ambulantes}

Foram entrevistados 12 homens e 8 mulheres ambulantes. Durante a pesquisa, constatou-se que o número de mulheres na atividade se iguala ao de homens e foram identificados perfis variados: são pessoas de estado civil diverso (casadas, divorciadas, viúvas e solteiras), dentre as quais há tanto mulheres jovens, quanto de mais idade. Em geral, os tipos de comércio escolhidos pelos vendedores ambulantes são de produtos alimentícios, manuais e industriais; artesanatos; roupas; e materiais escolares, sendo que a maioria dos entrevistados vendia alimentos, como cachorro-quente; minipizza; salgados; milho cozido; pamonha; curau; sorvetes; doces; pipoca; e churrasco grego.

$\mathrm{Na}$ atividade das vendedoras ambulantes, percebe-se dois tipos de relação: entre os espaço público e privado; e entre o "trabalho produtivo" e de "reprodução social e econômica". Os aspectos culturais e ideológicos marcam a inserção e permanência da mulher no trabalho dentro e fora de casa. Sua decisão passa pela existência da família, dos filhos e do cônjuge. Por tradição, a mulher no trabalho produtivo, formal ou informal, ainda é responsável pela manutenção da reprodução da força de trabalho no âmbito doméstico. Fica a dúvida se seu papel é o de provedora, juntamente com o marido, ou o de auxiliar no orçamento doméstico.

Os trabalho doméstico, trabalho reprodutivo, trabalho de cuidado nãoremunerado aos membros da família faz com que tais mulheres sejam classificadas como economicamente inativas, na mesma categoria dos estudantes, aposentados, doentes, inválidos e dos que vivem de renda ${ }^{328}$. Mais recentemente, tornou-se possível obter informações sobre esse conjunto de atividades, que consome tempo e energia de

328 BRUSCHINI, C. (1998). “Fazendo as perguntas certas: como tornar visível a contribuição econômica das mulheres para a sociedade?” IN: ABRAMO, L.; ABREU, A. R. P. (Orgs.). Gênero e trabalho na Sociologia latino-americana. São Paulo, Rio de Janeiro: Alast, p. 277-294 (Série II Congresso Latino-Americano de Sociologia do Trabalho). 
quem as realiza e que, na verdade, deveria ser considerado um trabalho nãoremunerado, ao invés de inatividade. SORJ ${ }^{329}$ tem a mesma opinião, ao se referir, em artigo recente, ao trabalho não-remunerado realizado principalmente por mulheres, na esfera privada, como uma das dimensões do trabalho social, ao lado do trabalho remunerado.

Entre as vendedoras ambulantes ou camelôs, a sobrecarga de trabalho também foi percebida. Precisavam comprar e preparar os alimentos que seriam vendidos na rua, lavar os mantimentos que seriam utilizados no dia seguinte, cuidar dos afazeres da casa, da alimentação da família e acompanhar os deveres escolares dos filhos. Além disso, era necessário considerar o tempo de deslocamento até o ponto de venda, que era em média de 1 a 2 horas. A maioria tomava no mínino duas conduções de ônibus, trem ou metrô, carregando materiais de trabalho pesados. As mulheres ocupavam até 16 horas do dia na realização das tarefas, restando, dessa maneira, pouco tempo para cuidados pessoais, lazer e sono. A maioria disse dormir entre 5 e 6 horas por noite durante a semana.

Algumas vendiam os produtos na rua e sob encomenda, para lojas, comércios, amigos e conhecidos. Quando retornavam para casa, cumpriam segunda jornada de trabalho, preparando os produtos enquanto cuidavam dos afazeres domésticos e dos filhos. Elas se referiam ao trabalho como um "bico" ou "dinheirinho a mais que entra" para pagar as despesas da casa. Parte das entrevistadas disse receber ajuda dos familiares para preparar alimentos e confeccionar peças de artesanato, por exemplo.

Com nível de escolaridade e experiência profissional maior que as colhedoras de laranja e catadoras de materiais recicláveis, muitas vendedoras ambulantes voltavam a estudar com a esperança de uma melhor inserção no mercado de trabalho. Depois de uma jornada intensa durante o dia, costumavam ir para a escola à noite. A disposição

329 SORJ, B. (2004). "Trabalho remunerado e trabalho não-remunerado". IN: OLIVEIRA, S. de; RECAMÁN, M. VENTURI, G. A Mulher brasileira nos espaço público e privado. São Paulo: Editora Fundação Perseu Abramo, p.107-119. 
para estudar e lutar para conseguir um trabalho que não fosse precário era percebida entre as trabalhadoras mais jovens e solteiras. Elas costumavam contar com apoio da família para comprar produtos, preparar alimentos, lavar mantimentos e equipamentos, entregar as encomendas aos clientes, ficar eventualmente na barraca quando a vendedora precisava se ausentar e realizar os afazeres domésticos.

As vendedoras casadas tinham maior limitação para voltar a estudar devido ao acúmulo de tarefas. A maioria reclamava que não tinha com quem dividir os afazeres domésticos, cuidados com os filhos e agregados. Era comum permanecerem na informalidade e incentivarem os maridos a terminarem os estudos, prestarem concurso público ou abrirem um negócio próprio que possibilitasse melhor rendimento e perspectiva. Encontramos camelôs cujas esposas estavam empregadas, possuíam grau de escolaridade maior e inclusive cursavam nível superior.

A estabilidade do emprego e a independência financeira possibilitavam que as esposas continuassem seus estudos. Nesse caso, os maridos permaneciam na informalidade devido ao rendimento maior e planejavam se qualificar depois que a companheira se formasse, em busca de melhorias na situação econômica familiar. As jovens e solteiras destacavam que o trabalho como ambulante era por pouco tempo e buscavam nos estudos uma maneira de obter melhor inserção no mercado de trabalho.

Ao ser questionada pela pesquisadora sobre as tarefas domésticas, a maioria das mulheres comentou que nesse aspecto quase "nada mudou". Precisavam conciliar a vida profissional, os estudos e o trabalho doméstico na medida do possível. Abriam mão das horas de lazer, descanso e cuidados consigo mesmas. Ressaltaram que a maior parte das tarefas de casa e dos cuidados com os filhos era de sua responsabilidade. Apesar disso, lembraram também que "muitas coisas mudaram", pois hoje os maridos permitiam que elas estudassem e trabalhassem, enquanto suas avós e mães não puderam estudar, nem 
trabalhar. Além disso, os homens ficavam com os filhos quando elas estavam muito ocupadas, arrumando a casa, cozinhando, lavando e passando roupa, entre outros trabalhos. No passado, os pais das entrevistadas nunca tinham tomado conta delas, nem de seus irmãos.

Percebeu-se que a continuidade dos estudos e o sucesso profissional eram conseguidos a custo de muitas tensões, conflitos, sobrecarga de trabalho, estresse e sofrimento psíquico. Dificilmente, argumentavam querer trabalhar e estudar pela realização pessoal. Era mais comum ouvir, por exemplo, que queriam ter o próprio dinheiro, poder comprar o que gostavam e aumentar seu conhecimento. A justificativa estava relacionada a aspectos externos à trabalhadora, preocupada em conseguir ou manter um emprego, ter melhor remuneração para contribuir com o sustento dos filhos e pagar demais gastos em casa.

Quando as crianças não estavam na escola, as vendedoras ambulantes deixavam os filhos aos cuidados de algum familiar, ou pagavam alguém para ficar com eles. $\mathrm{O}$ horário flexível foi mencionado como vantagem para poder conciliar os afazeres domésticos, cuidados com filhos e o trabalho na rua. Foi observado o caso de um camelô que preferia permanecer na informalidade justamente pela necessidade de acompanhar o tratamento médico do filho, que tinha paralisia cerebral. Outra entrevistada precisava cuidar do marido que tinha passado por uma cirurgia do coração há pouco tempo e tinha como dependentes os pais idosos. Outros diziam querer ficar mais tempo com os filhos.

Para os homens, o "bico", ou trabalho informal era uma opção aceitável como último recurso. Esse tipo de ocupação era considerado temporário, mas por várias circunstâncias tornava-se permanente. Para alguns trabalhadores, era motivo de "vergonha", "desonra" e "frustração" por não ter conseguido manter um trabalho 
estável, com carteira de trabalho e que desse status, mesmo ganhando mais dinheiro na informalidade. Eles preferiam dizer que eram "autônomos", "trabalhadores por conta própria" e "donos de um negócio" a se apresentarem como "camelôs" e "vendedores ambulantes". Esta identidade profissional era escondida no momento de solicitar um crediário ou empréstimo de familiares e amigos.

Para as mulheres, ao contrário, ser ambulante poderia ser visto como favorável na medida em que lhes permitia dedicar atenção aos cuidados com a família e a casa. As trabalhadoras não aceitavam de forma passiva a imposição cultural por meio da qual seu trabalho na rua era visto como provisório até que os maridos conseguissem uma reinserção no mercado ou algo mais rentável, nem consideravam sua atividade menos importante. Afirmavam dividir as contas a pagar ou serem responsáveis pela maior parte das despesas em casa. Além disso, cuidavam dos filhos, afazeres domésticos, doentes, idosos, faziam vários "bicos" por falta de alternativa - precisavam do trabalho para evitar maiores conflitos e desavenças no lar.

Através da pesquisa, percebeu-se que na divisão sexual do trabalho persistia a exploração e o lado perverso. As mulheres acumulavam funções, ficavam sobrecarregadas por várias atividades e não eram respeitadas como profissionais. Para algumas, o "bico" significava ter que "ajudar" o marido, chefe de família e provedor, e não receber "salário" em troca, ou não ter participação na decisão dos gastos em casa. Dessa forma, o trabalho da mulher dentro e fora de casa possuía status social de pouco prestígio. O trabalho fora de casa era apenas um "bico" e "quebra galho" permanente. O trabalho doméstico era invisível. Na maioria dos casos, a esposa era quem "ajudava" o marido em sua atividade profissional. Quando isso não acontecia, filhos ou parentes costumavam "auxiliar" o camelô em determinados períodos ou o dia todo. Nessa 
situação, o trabalho familiar caracterizava a atividade de camelô. Uma das vendedoras ambulantes revelou o seguinte:

$\mathrm{Na}$ hora do almoço e no fim da tarde eu fico na barraca de cachorro-quente com meu marido. Eu ajudo a fazer os lanches, a vender os salgados e doces e a cuidar do caixa. É muito corrido. Não podemos perder clientes. É bom atender logo e não deixar esperando. Depois, meu marido vai ao banheiro e almoça. Eu aproveito para comer junto. Levo a comida de casa fresquinha. Depois volto para casa, vou ao mercado fazer compra dos produtos no mercado, faço o jantar e espero ele voltar. Depois eu preparo os temperos e molhos para o dia seguinte. No final da tarde, meu filho mais velho fica na barraca com o pai e volta de carro com ele. Depois que meu marido chega, ele lava todos equipamentos, as caixas de alumínio, limpa a geladeira e o freezer . Vamos dormir tarde para acordar bem cedo. Eu cuido da casa, lavo roupa, fico com os filhos menores de manhã.

A violência no trabalho contra as mulheres camelôs ocorre nos momentos de "rapas"330 da Guarda Municipal. Entre as entrevistadas, estava a coordenadora do Movimento Unidos dos Camelôs do Rio de Janeiro (MUCA), Maria de Lourdes (Maria do Camelô), que sofreu várias agressões físicas, mesmo quando estava grávida de sete meses. A vendedora ambulante relatou o seguinte:

\section{Maria de Lourdes}

Eu fiquei desempregada. Trabalhava em postos de gasolina como frentista e fui mandada embora. Tinha dois filhos pra criar, aluguel pra pagar. Depois fiquei grávida do meu terceiro. Tinha que arrumar alguma coisa pra fazer. Consegui um "bico"

330 O "rapa" é a ação de apreensão de mercadorias vendidas pelos vendedores ambulantes pelos fiscais da Prefeitura. Quando os vendedores demonstram resistência para entregar as mercadorias é comum ocorrer atos de violência por parte da Guarda Municipal. 
de vendedora de papéis para presente na época do Natal. Na rua é só colocar alguma coisa pra vender que a gente consegue ganhar algum dinheiro rápido. A dona dos papéis arrumou outro serviço e eu continuei na rua. Ia na loja de atacado comprava de monte e vendia e ganhava. No Carnaval estava vendendo máscaras, fitas, confetes, brinquedos numa banquinha. De repente ouvi o pessoal gritando 'olha o rapa! Olha o rapa!'. Todo mundo corria. Eu juntei tudo e comecei a correr também. Os guardas vieram pra cima com cacetes. Tinha até cavalos. Eu tinha barriga e tudo, tava grávida e eles me bateram nas costas e pernas! Fiquei toda roxa. Ainda bem que não aconteceu nada com a criança.

A segunda agressão que Maria do Camelô sofreu foi logo após o nascimento do terceiro filho. Ela não tinha como parar de trabalhar. Foi obrigada a suspender a amamentação natural em função do trabalho. Pagava uma pessoa para cuidar dos filhos. Saia bem cedo e retornava à noite. Morava no subúrbio e levava mais de duas horas para chegar ao centro da cidade. Os camelôs estavam de sobreaviso que haveria alguma intervenção da Guarda Municipal. Todos estavam com medo, mas continuavam trabalhando normalmente. Maria tinha boa relação com os líderes dos camelôs. Sugeriu que eles conversassem com a fiscalização e a GM para que não ocorresse nenhuma violência. Considerava mais prudente uma retirada dos ambulantes de maneira pacífica. A camelô comentou que:

\section{Maria de Lourdes}

Eles vieram empurrando a gente. Ficamos encurralados numa rua. Não adiantava gritar, pedir para parar e conversar, pedir calma. Eles não queriam negociar. Queriam bater!!!!. Eu fiquei preocupada que tinha muita gente idosa, deficientes físicos, crianças, filho... Corri para tentar defender uma velhinha que 
vendia café. Eles me pegaram pelo braço e me derrubaram no chão. No meio da pancadaria, eu apanhei muito. Fazia menos de um mês que meu filho tinha nascido. Ainda sentia dores no local dos pontos (da cirurgia). Depois disso, disse basta! Comecei ir até a CUT com alguns camelôs. Pedimos ajuda e apoio para os Sindicatos dos Bancários, outros sindicatos. Depois de um ano, fundamos o MUCA (Movimento dos Camelôs Unidos do Rio de Janeiro). Fizemos várias passeatas pedindo a regulamentação da profissão e o fim da violência. Hoje em dia o Movimento está fraco, cada um cuida da sua vida e não pensa em organizar. Eu continuo trabalhando e militando e nunca esqueço dos camelôs. Temos que mudar essa situação.

As mulheres camelô sofriam assédio moral ao fazer Boletim de Ocorrência devido às agressões físicas. Os delegados costumavam tratá-las com insultos e ironias, dizendo que "se fossem mulheres sérias, de respeito, não seriam camelôs", pois como estavam vendendo produtos na rua, "só poderiam ser ladras e bandidas". Recebiam agressões verbais de clientes quando esses não ficavam satisfeitos. Não se sentiam seguras para reclamar para alguma autoridade, pois sabiam que seriam desrespeitadas ou ignoradas no seu direito.

\subsubsection{Algumas considerações}

Em uma perspectiva mais ampla, os resultados dos estudos sobre gênero e trabalho sinalizam para a necessidade de políticas públicas de proteção ao trabalho da mulher que extrapolem a dimensão do mercado de trabalho, alcançando as atividades 
complementares que a população ativa realiza no interior das famílias. Nesse sentido, a reprodução econômica e social requer uma boa administração das atividades, tanto no espaço das empresas, quanto naquele das famílias.

As políticas são especialmente relevantes para as mulheres e, em especial, para aquelas com menor qualificação e renda, pois são elas que se encontram em maior desvantagem tanto no mercado de trabalho, como nas famílias. Ao contrário da perspectiva que defende uma menor regulação pública do mercado de trabalho, muitas vezes sob a justificativa da maior liberdade das partes no processo de contratação, verifica-se a necessidade de ampliação desta regulação, pois ela constitui um elemento relevante para o enfrentamento das desigualdades entre homens e mulheres no mercado de trabalho e no núcleo familiar.

As questões do acúmulo de funções e tarefas e da jornada de trabalho prolongada dentro e fora de casa foram os aspectos que mais chamaram a atenção ao longo da realização deste estudo. As condições de desigualdade das mulheres perante os homens se revelaram, entre outros aspectos, pela persistência da responsabilidade das mulheres e das mães pelos afazeres domésticos e pelos cuidados com as crianças e demais familiares, como se constatou através do elevado número semanal de horas de trabalho que elas dedicavam a essas atividades. Segundo Bruschini ${ }^{331} 332$, o número médio de horas semanais dedicadas ao trabalho doméstico da população total é de 21,9 horas, sendo que as mulheres dedicam cerca de 27 horas e os homens, pouco mais de 10 horas ao trabalho doméstico.

331 BRUSCHINI, C. (2006). “Trabalho doméstico: inatividade econômica ou trabalho não remunerado?” R. Bras. Est. Pop., São Paulo, v. 23, n. 2, jul./dez., pp. 339 .

332 Idem (2007). ."Trabalho e gênero no Brasil nos últimos dez anos”. Cadernos de Pesquisa, v. 37, $\mathrm{n}^{\circ} 132$, set./dez., pp. 544 
Dedecca $^{333}$ percebeu em seu estudo que as mulheres têm jornadas de trabalho totais mais longas. Na tentativa de conciliar a necessidade de desempenhar as tarefas domésticas com a inserção no mercado de trabalho, elas trabalham em média 18 horas semanais a mais que os homens. Segundo o autor, quanto mais desfavorável a inserção ocupacional da mulher e quanto mais baixa sua renda, maior é a distância entre a jornada de trabalho a que ela está submetida e aquela dos homens na mesma condição.

Os resultados gerais do estudo de Dedecca mostraram que, em 2006, homens e mulheres ocupadas tinham jornadas totais de trabalho de 49 horas e 56 horas, respectivamente. Contudo, a composição desta jornada era significativamente distinta entre os sexos. Os homens tinham uma jornada de trabalho média equivalente à jornada constitucional de 44 horas e destinavam cinco horas para a reprodução social. Já as mulheres tinham jornadas de 37 horas e 19 horas, respectivamente, o que resulta numa jornada de trabalho total em média $15 \%$ superior à dos homens.

Além disso, o autor comentou que quanto pior a qualidade da ocupação da mulher, maior sua jornada total de trabalho e maior a participação do trabalho em casa na apropriação do seu tempo; assim sendo, menor era o tempo que ela podia dedicar ao trabalho fora de casa - o que apontava na direção de uma inserção de pior qualidade no mercado. O nível mais baixo de escolaridade também estava associado a jornadas de trabalho total maiores e com maior participação das mulheres nas horas dedicadas à reprodução social, e essa situação se agravava para as mulheres chefes de família.

A análise da jornada dos ocupados por escolaridade e ocupação revelou, segundo Dedecca, que no caso das mulheres, a dimensão renda era tão relevante para compreender a dinâmica de formação e composição da jornada de trabalho quanto a escolaridade. As mais elevadas jornadas femininas destinadas à reprodução social 
estavam associadas a escolaridades mais baixas e ocupações menos qualificadas, como o trabalho agrícola, os serviços e o comércio.

Por outro lado, as mulheres mais escolarizadas e que exerciam ocupações com maior prestígio social (como as dirigentes e as profissionais das ciências e das artes) tendiam a buscar uma melhor inserção no mercado, o que fazia com que elas delegassem as atividades domésticas a trabalhadores - e especialmente trabalhadoras remunerados/as para exercê-las. Portanto, havia uma relação inversa entre nível de escolaridade e jornada de trabalho destinada à reprodução social: mulheres com baixa escolaridade tendiam a ter jornadas domésticas em média $75 \%$ superiores às das mulheres com nível superior completo.

Para Dedecca, a consideração conjunta de posição na família e classes de renda por salário mínimo permite observar que as mulheres chefes de família têm uma carga inversamente proporcional à renda de responsabilidades sobre a reprodução social. As mulheres de baixa renda e grandes responsabilidades sobre a reprodução social têm pouca possibilidade de realizar uma inserção de qualidade no mercado: estão muito comprometidas com as tarefas domésticas e conseguem dedicar uma fração pequena do seu tempo ao mercado de trabalho. Embora as mais elevadas jornadas totais estejam ligadas às mulheres ocupadas que auferem rendimentos ente dois e três salários mínimos, o tempo apropriado pelas tarefas domésticas é $100 \%$ maior para as mulheres com rendimento inferior a um salário mínimo, em relação às de renda mais alta.

Em meu estudo, as mulheres, muito mais que os homens, dedicam parte significativa de seu tempo ao trabalho para a reprodução social. As esposas e, principalmente, as mães de filhos pequenos são as que dedicam número mais elevado de horas semanais aos afazeres domésticos. Para Bruschini ${ }^{334}$, tal constatação se torna mais

334 BRUSCHINI, C. (2006), p. 351. 
relevante ao se considerar o fato de que são justamente essas mulheres que vêm adentrando e permanecendo com mais vigor no mercado de trabalho desde os anos 80 .

Ou seja, são as mulheres que mais trabalham atualmente na atividade produtiva as que mais consomem seu tempo, no domicílio, na atividade reprodutiva, enfrentando enorme sobrecarga de trabalho e dificuldade de conciliação entre as responsabilidades familiares e as profissionais. Nesse sentido, a autora defende a proposta de que o trabalho doméstico passe a ser considerado um trabalho não-remunerado ao invés de inatividade econômica.

Dedecca et alli $^{335}$ destaca a necessidade de políticas públicas de proteção ao trabalho que extrapolem a dimensão no mercado de trabalho, alcançando as atividades complementares que a população ativa realiza no interior das famílias. Estas políticas são particularmente relevantes para as mulheres e, em especial, para aquelas com menor qualificação e renda, pois são elas que se encontram em posição mais desvantajosa tanto no mercado de trabalho como nas famílias. A ampliação da regulação pública do mercado de trabalho constitui em elemento relevante para o enfrentamento da desigualdade entre homens e mulheres no mercado de trabalho e no núcleo familiar.

\subsection{Condição dos jovens}

Segundo dados da Organização Internacional do Trabalho (OIT), uma em cada cinco pessoas com idade entre 15 e 24 anos estava desempregada em $2004^{336}$. O número corresponde a 88 milhões de jovens, que representavam mais de $40 \%$ do total de

335 DEDECCA, C. S.; RIBEIRO, C. S. M. F.; ISHII, F. H. (2008). p. 18.

336 OIT (Organização Internacional do Trabalho)(2004). A OIT e o emprego de jovens. Boletim Informativo do Programa Especial - Emprego e formação de jovens, p.1, http://www.oit.org.br. Consulta realizada em 03/05/2009. 
desempregados ${ }^{337}$ no mundo. Nos países em desenvolvimento, encontravam-se $85 \%$ deles. A OIT estimava que 660 milhões de jovens ingressariam no mercado de trabalho nos dez anos seguintes. No Brasil, o desemprego de 3,5 milhões de jovens com idades entre 16 e 24 anos, ou seja, cerca de $45 \%$ da força de trabalho nacional, reforçava a preocupação dos órgãos competentes com o emprego de jovens.

A possível falta de oportunidades de emprego suficientes para acomodar essa força de trabalho e a qualidade dos empregos, que deveriam ser produtivos e decentes, eram preocupações constantes. Identificou-se que 93\% dos empregos disponíveis para os jovens brasileiros estavam na economia informal. Eram ocupações com baixa remuneração, pouca ou nenhuma segurança, praticamente sem benefícios ou perspectivas de crescimento. Essas atividades de trabalho não exigiam escolaridade ou qualificação.

É importante ressaltar o quanto é comum encontrar nos jovens hoje desempregados os trabalhadores infantis do passado. Dessa maneira, o aumento das oportunidades de trabalho decente para jovens não pode estar dissociado das iniciativas de erradicação do trabalho infantil e de melhorias no sistema educacional. Essas medidas possibilitarão melhores perspectivas de emprego para adultos.

Segundo Cacciamali ${ }^{338}$, os jovens das famílias mais pobres encontram grandes dificuldades para se manterem no sistema escolar, ou se inserirem em ocupações com perspectivas de mobilidade social, perpetuando assim a reprodução de um quadro de estratificação social com elevadas desigualdades. Nos anos 90, os jovens das famílias pobres foram os mais prejudicados no processo mais amplo da exclusão juvenil do mercado de trabalho nos anos 90 .

337 Dados estatísticos da Organização Internacional do Trabalho, 2004 338 CACCIAMALI, M. C. \& BRAGA, T. (2002). "Educação e Trabalho da População Jovem - Diagnóstico e Políticas". IN: Estudos e análises com vistas à definição de políticas, programas e projetos relativos ao mercado de trabalho brasileiro, tema 18. Ministério do Trabalho e Emprego e Fundação Instituto de Pesquisas Econômicas (FIPE), São Paulo, pp. 5-6. 
Durante minha pesquisa de campo, foram encontrados jovens (entre 15 e 24 anos) em todas as ocupações estudadas (camelô, pescador de lagosta, colhedor de laranja e catador de materiais recicláveis). Os trabalhadores jovens foram inseridos no mercado de trabalho ainda na infância, tanto no sistema de trabalho familiar, quanto no assalariamento. Apesar da pouca idade (pois começavam a partir dos 10 anos), era considerado normal trabalharem na lavoura, na roça, na criação de gado e outros animais, ou nos pequenos negócios e serviços, como a venda de doces, balas, frutas, salgados, canetas, lixa de unha; puxando carrinhos na feira; carregando sacolas; engraxando sapatos; como entregadores de compras; office-boys; "flanelinhas"; e no trabalho doméstico, para citar algumas ocupações comuns.

O horário de trabalho das crianças costuma ser menos rígido. A maioria desenvolvia atividades junto à família, fato que lhes possibilitava frequentar a escola. Já o trabalho dos adolescentes era bem mais formal, isto é, ocupava boa parte de seu tempo, tinha carga horária estabelecida, controle por parte de chefias e patrões, sendo que não eram permitidas as faltas sem justificativa, entre outras características. Percebeu-se que a falta de motivação pela escola e as responsabilidades com o trabalho não facilitavam a continuidade nos estudos.

A maioria tentou trabalhar e estudar até o ensino fundamental. Alguns conseguiram conciliar as atividades e se formaram. Outros desistiram de ir a escola já no $5^{\circ}$ ano, confirmando a ocorrência de evasão escolar precoce. Foram raros os casos de jovens que alcançaram o nível médio e ainda menos atingiam o universitário. A trajetória escolar da maioria era marcada por inúmeras repetências e desistências. Percebeu-se que os níveis de escolaridade dos trabalhadores que nasceram e cresceram na área rural eram menores que os da área urbana. 
De acordo com Rocha ${ }^{339}$, a combinação de trabalho e estudo cresce paulatinamente a partir dos 10 anos, com uma contribuição maior nas áreas rurais, e atinge o seu pico aos 17 anos. Dessa maneira, a mudança drástica em termos de entrada no mundo do trabalho ocorreria entre 17 e 19 anos, o que significa forte aumento da entrada no mercado, com abandono definitivo da escola nessa faixa etária. Sendo assim, a combinação trabalho/escola começa a declinar a partir dos 17 anos no campo, enquanto para os jovens residentes nas metrópoles a quantidade de trabalhadores que estudam continua a aumentar, tanto pelos incentivos do mercado de trabalho, como pela maior facilidade de acesso à escola.

Entre os fatores que interferiam no desempenho escolar, os entrevistados mencionaram a jornada prolongada; o ritmo de trabalho intenso; as dificuldades econômicas; a necessidade de ajudar a família; mudanças de cidade; e a ausência de escolas próximas ao local de moradia. Porém, todos foram unânimes ao afirmar que sentiam falta de motivação e interesse pelos estudos e na escola. A maioria estava atrasada nos estudos, sendo comum encontrar alunos que repetiam a mesma série várias vezes, o que os desmotivava a continuar estudando. Percebeu-se que o "fracasso escolar" tinha muito mais a ver com a qualidade do ensino e com o sistema educacional brasileiro, do que com o interesse do próprio aluno pelos estudos, o trabalho, a família, ou diferentes dimensões do sistema socioeconômico e político.

Os jovens disseram sentir dificuldade para entender e aprender o que era ensinado, o que fazia com que se sentissem culpados, incompetentes e inadequados. A convivência social na sala de aula era dificultada pelas diferenças de idade entre os alunos. $\mathrm{O}$ ensino fundamental incompleto prevaleceu entre os trabalhadores da amostra. Em todas as ocupações, foram encontrados analfabetos, ou jovens que frequentaram 
apenas as primeiras séries e sabiam somente assinar o próprio nome e fazer cálculos mais simples. O mais preocupante foi encontrar jovens que, pela desmotivação em relação aos estudos, a necessidade de lutar pela sobrevivência e a constituição da própria família abandonavam a escola e não conseguiam mais retornar.

Foi identificada a existência de um círculo vicioso, em que a baixa escolaridade, a falta de experiência e a pouca qualificação propiciavam apenas trabalhos informais e precários. A atividade informal ou "bico" era considerada provisória até o momento em que surgissem melhores oportunidades, ou seja, o "emprego estável”. No entanto, durante a pesquisa com entrevistados de diversas faixas etárias, foi possível perceber como a mesma situação do passado continua a se reproduzir em meio às novas gerações: aquilo que deveria ser provisório pode se tornar permanente ou, no mínimo, os trabalhadores com o perfil descrito, acabam intercalando atividades informais e formais ao longo de sua trajetória profissional. É importante destacar que o fenômeno das mudanças constantes de trabalho foi observado principalmente na juventude e na maturidade.

Para os jovens, as atividades informais podiam dificultar o retorno aos estudos, devido à instabilidade financeira e à intensificação do trabalho. Por outro lado, possibilitava uma flexibilidade de horários e autonomia. Os trabalhadores autônomos, como os vendedores ambulantes e catadores de materiais recicláveis, tinham mais facilidade de retornar aos estudos que os assalariados sem carteira. Entre os camelôs, foram encontrados jovens que retornaram à cidade de origem, no Nordeste, para estudar. Nesse caso, não eram chefes de família e puderam contar com outras pessoas para dividir os gastos com a sobrevivência. Um exemplo positivo foi o de um rapaz de 22 anos da Paraíba, que disse o seguinte: 
Luis

Eu trabalhava na roça em São Bento com minha família. Com 14 anos, comecei a viajar, vendendo mantas e colchas feitas na cidade. Passei quatro anos viajando pelo Brasil. Cansei e não aguentava mais. Ganhava bem... uns 2 salários. Fiquei quase doente e vi que não dava mais. Aquilo não era vida. Voltei para casa e fui trabalhar na roça de novo, junto de minha família. Ganhava quase nada, só um pouco. O dinheiro era da família. Voltei a estudar e terminei o ensino médio. Foi dureza mesmo! Trabalhava com enxada, na colheita, plantando num sol de rachar. Ia estudar à noite, cansado e com sono. Formei o segundo grau. Vim pra São Paulo e fui trabalhar no metrô, na limpeza, serviço geral. Um amigo indicou. Estou há um ano. Limpava a parte do laboratório e o chefe gostou de mim. Comecei a ajudar no laboratório. Depois passei prá auxiliar de laboratório. Ganho um pouco mais que na rua, mas tenho carteira registrada, plano de saúde, direitos que antes não tinha. Hoje tenho maior segurança. Não preciso mais ficar viajando de um lado pro outro. Correndo da fiscalização, da GM (Guarda Metropolitana) no "rapa". Agora tenho mais tranqüilidade. Mando dinheiro pra minha mãe e ainda dá pra viver aqui. Ajudo minha família na Paraíba. Quero estudar mais, fazer técnico de laboratório.

Como no caso de Luís, o retorno à escola era em geral feito com dificuldade. As famílias dos trabalhadores jovens viviam em situação de pobreza. Era comum que os pais e inúmeros irmãos tivessem pouca ou nenhuma escolaridade. Nessa medida, era impossível contar com apoio financeiro total e assistência nos estudos por parte de familiares, em caso de necessidade. Em alguns casos, os jovens, entrevistados em meu estudo, eram os únicos provedores ou responsáveis pela maior parcela das dívidas na 
casa. Em época de crise econômica, era comum encontramos várias pessoas desempregadas nas famílias.

Em outras situações, além das responsabilidades financeiras os trabalhadores tornavam-se precocemente chefes de família. Eram responsáveis pelo sustento e cuidado de irmãos, irmãs, pai, mãe e agregados. Os jovens deixavam de ser dependentes da família e, pelo contrário, o núcleo familiar passava depender do trabalhador jovem.

A questão de gênero estava presente na relação entre trabalho e educação, segundo Cacciamali e Braga. As mulheres tinham menores possibilidades de continuar os estudos. Além da inserção em trabalhos precários, eram responsáveis, por exemplo, pelos afazeres domésticos e cuidados com irmãos menores e doentes. $\mathrm{O}$ abandono da escola era freqüente, principalmente no caso de gravidez precoce e casamento ${ }^{340}$. Em meu estudo foi observado jovens que abandonaram os estudos por causa de filhos, do matrimônio e do trabalho dentro e fora de casa. Uma jovem de 24 anos que cursou até a $6^{\circ}$ série e trabalhava como camelô declarou:

\section{Maira}

Eu trabalho deste os 13 anos. Primeiro trabalhei como empregada doméstica. Fiquei dois anos. Parei de estudar porque não dava tempo. Engravidei com 16 anos. Fui morar com o pai da criança. Ele era camelô. Eu comecei a trabalhar com ele na barraca. Depois a gente se separou. Agora trabalho na barraca de um conhecido. Estou nessa vida há sete anos. Trabalho de segunda a segunda, doze horas por dia. Pego dois ônibus e trem para chegar aqui. Levo quase duas horas. Moro com minha irmã e mãe. Chego em casa e tenho que cuidar de meu filho, lavar roupa. Recebo R\$100,00 por semana, mais condução e refeição. Estou (trabalhando) na rua para ganhar mais. Queria um 
emprego com carteira, mas acho difícil conseguir. Se conseguir, vou ganhar menos por causa dos descontos. Quero outra vida para meu filho.

Durante a pesquisa, ficou claro que apesar das limitações e dificuldades, os jovens tinham expectativa de conseguir um emprego estável, ter profissão, ser "alguém na vida" e ter dinheiro para comprar carro, moto, roupas, jeans, tênis, som e outros produtos. Os objetos de consumo eram típicos do universo juvenil. Tinham consciência da importância dos estudos e de uma melhor qualificação para alcançar essas metas. Porém, lembravam-se das inúmeras tentativas sem sucesso de retornar à escola. A esperança de um dia poder "se formar" e "tirar o diploma" diminuía com o passar do tempo para maioria dos jovens. Para um número expressivo deles, a única alternativa era a inserção em trabalhos informais e precários.

Alguns jovens, após experiência de desemprego, preferiam fazer "bicos" para obter maiores rendimentos e viver a experiência da liberdade e autonomia que não encontravam no sistema de trabalho fabril. Foi entrevistado um jovem de 21 anos do interior da Paraíba. Com ensino fundamental completo, fazia "bico" vendendo mantas e cobertores nas ruas de São Paulo. Com isso, ganhava quase dois salários mínimos. Nas datas comemorativas como Natal e Dia das Mães o trabalhador recebia até três salários. O emprego anterior era de ajudante de operador de máquina em uma indústria têxtil, na cidade de São Bento, Paraíba, onde ganhava um salário com carteira assinada.

Ele dizia que após perder o emprego não sabia o que queria da vida. Só pensava em comprar uma moto, como fizeram os amigos, e passear pela cidade com a namorada. O jovem gastou o dinheiro da rescisão de contrato e contraiu dívidas para adquirir o veículo. Depois de algum tempo, sofreu um acidente de trânsito. Para pagar as parcelas do financiamento, tornou-se vendedor ambulante, viajando por vários estados e países 
na América Latina. Apesar de viajar em condições precárias, isto é, dentro de um caminhão baú com 30 pessoas em cima das mercadorias, pouca ventilação e correndo risco de morte por acidente de trânsito, o trabalhador comentou que:

\section{Clayton}

No início, a experiência era aventura de conhecer diferentes Estados, outros países como Buenos Aires, Montevidéu, Cidade Del Leste (no Paraguai) e interior do Chile. É bom ganhar mais dinheiro. Chego tirar até 3 salários mínimos por mês, quando a venda está boa. Depois sete anos viajando, dormindo sem conforto no caminhão ou em redes, nas paradas, nos postos de gasolina, comendo na rua, tomando banho nos postos, passando frio, trabalhando seis dias por semana durante 12 doze a quinze horas por dia, debaixo de sol, chuva, correndo dos guardas no "rapa", tirando quinze dias de descanso por ano, sofrendo acidente, eu estou cansado. Não tenho mais pique prá isso. Queria voltar prá ficar perto de minha família lá em São Bento. Sinto a maior saudade, chego a chorar. Já perdi várias namoradas que deixei lá. Não sei se acostumo a ganhar pouco de novo, ter chefe pegando no pé, em cima o tempo todo. Lá não tem opção. Aqui pelo menos ganho mais. Depois que você se acostuma fica difícil ganhar menos. Agora trouxe meu irmão comigo. Ele tem 16 anos (estudou até o $4^{\circ}$ ano, mas não sabia ler, nem escrever, estava aprendendo a somar e subtrair. Pede ajuda para Clayton quando precisa) e eu não posso deixar ele sozinho. Vou continuando até quando der.

O jovem não soube dizer o que esperava do futuro. Disse apenas que queria voltar a morar no Nordeste, em São Bento, na Paraíba, mas não tinha perspectiva quanto ao trabalho. Talvez abra um negócio próprio com o dinheiro que conseguiu economizar nesses sete anos como vendedor ambulante. Em relação aos estudos, fez os seguintes 
comentários: "não tenho cabeça boa para estudar"; "sinto dificuldade de aprender"; "não tenho paciência de ficar ouvindo os professores falando, falando, falando sem parar"; "vou estudar prá que? Prá ser servente de obra, trabalhar de ajudante? Isso eu já fiz"; "Fiz até a $8^{\circ}$ série (ensino fundamental) porque minha mãe mandava, me obrigava"; "não tem tanto emprego assim... lá na minha terra tem muitos colegas que terminaram o ensino médio e estão desempregados e fazendo 'bicos'”.

Percebeu-se que o rapaz apresentava um comportamento típico da juventude. Desejava ter dinheiro para consumo próprio, além de ajudar a família. Queria se livrar da disciplina existente no emprego regular. Tinha expectativa de liberdade, autonomia e aventura em um trabalho que possibilitava um bom rendimento, viajar e conhecer diferentes cidades. Ganhava relativamente bem em relação aos trabalhadores com sua escolaridade e qualificação. Após longos anos de atividade, estava cansado, sem perspectiva de crescimento profissional e planejava mudar de vida. A única saída para continuar sendo autônomo era abrir um pequeno negócio na cidade de origem.

O entrevistado sentia-se culpado pelas escolhas que fez na vida e tomava a responsabilidade para si pelo fato de não conseguir dar continuidade nos estudos. Tinha consciência do momento de crise econômica e falta de emprego, mas não relacionava a questão da escolaridade e qualificação com maior oportunidade de trabalho. Apesar de Luís (relato acima) ter retornado aos estudos e conseguido um trabalho com carteira assinada em São Paulo, Clayton acreditava não ser capaz e duvidava que tivesse a mesma "sorte" que o amigo.

Martins $^{341}$ e Guimarães ${ }^{342}$ assinalam que o trabalho é uma dimensão relevante para as pessoas nas sociedades modernas, pois consiste em elemento estruturador na

341 MARTINS, H. H. T. S. (1997). "O jovem no mercado de trabalho. Juventude e contemporaneidade”. Revista Brasileira de Educação, São Paulo, n $5 / 6$, p. 96109, maio-agosto/setembro-dezembro, Edição Especial.

342 GUIMARÃES, N. A (2005). "Trabalho: uma categoria-chave no imaginário juvenil?”. In: ABRAMO, H. W.; BRANCO, P. P. M. Retratos da Juventude Brasileira. São Paulo: Instituto Cidadania; Editora Fundação Perseu Abramo, pp. 149-174. GUIMARÃES, N. A.(2006). Trajetórias inseguras, autonomização 
composição psicológica das pessoas e no ciclo de suas atividades diárias. A importância do trabalho para os jovens está relacionada à independência financeira; autonomia; estruturação do tempo, tendo como referência uma rotina diária de trabalho; laços de sociabilidade; reconhecimento pelos familiares e amigos; possibilidade de convívio em outros espaços sociais; e um espaço de proteção da marginalidade e da violência em geral, entre outros significados.

Assim, a experiência ou inexperiência no trabalho constitui elemento importante na estruturação da identidade social. Como uma das dimensões que constituem as identidades juvenis, o trabalho assume diversos significados e desencadeia diferentes atitudes e trajetórias, dependendo do contexto e segundo os recortes de gênero, raça, classe e origem social, sejam a partir de suas experiências como trabalhadores ou desempregados.

Segundo essa perspectiva, o fato de não trabalhar ou de ser obrigado a se ajustar a qualquer emprego pode significar, para muitos jovens, principalmente aqueles com menos recursos econômicos e sociais, uma fonte de sofrimento e ausência de perspectivas quanto ao futuro. Dessa maneira, os jovens manifestavam uma atitude realista e desencantada em relação ao trabalho diante das dificuldades que encontravam para se inserir e manter no mercado de trabalho.

Guimarães $^{343}$ analisou as atitudes dos jovens diante do trabalho a partir dos dados de uma pesquisa nacional sobre o perfil da juventude brasileira. Como eixo condutor de sua análise estava a idéia de que, para além da tese do fim da centralidade do trabalho nas sociedades contemporâneas, os dados indicavam que o trabalho não apenas ainda estava na ordem do dia, como se destacava com relação a outros aspectos tidos como reveladores de interesses "tipicamente juvenis".

incerta: os jovens e o trabalho em mercados sob intensas transições ocupacionais. In: Transição para vida adulta ou vida adulta em transição? Rio de Janeiro: IPEA, pp. 182-183.

343 GUIMARÃES, N. A (2005), pp. 156-157 
A importância do trabalho na vida dos jovens se revelava a partir de diferentes sentidos atribuídos. Para uma parcela minoritária dos jovens ${ }^{344}$, a dedicação ao trabalho era um valor. Outro significado do trabalho para os jovens se colocava no plano da necessidade que advém da experiência do desemprego e da falta de rendimento. Este sentido se destacava especialmente para os jovens com menor escolaridade e rendimentos, como no caso dos entrevistados do estudo que conduzi. Um último significado atribuído ao trabalho refere-se à noção de direito, seja como detentores de um direito que exercem (jovens com experiência regular de trabalho), seja como sujeitos carentes de um direito (jovens desempregados).

Segundo Martins ${ }^{345}$, para alguns jovens que têm melhores recursos econômicos, culturais e sociais, o significado de desemprego e falta de trabalho relaciona-se como um tempo de investimento na sua formação geral ou profissional. Mas para muitos jovens que não trabalham, a situação de desemprego pode ser vivida de forma negativa, como uma incapacidade quanto a projetar o futuro. Sendo assim, o desemprego acarreta sentimento de desesperança, ansiedade, vergonha e culpa.

Para os jovens que já trabalham, a relação com o trabalho passa a ser mediada pela ameaça do desemprego. Esse passa a ser um elemento constitutivo dos horizontes possíveis para a experiência juvenil nas sociedades contemporâneas, como relata Martins $^{346}$ acerca de uma pesquisa sobre jovens metalúrgicos:

Fiquei impressionada com o número de jovens já com famílias constituídas, sem possibilidade nenhuma de desfrutar algum tipo de lazer, de participar de um grupo de jovens, de se associar a um movimento - mesmo os sindicalizados não participam do

344 Jovens com 18 a 20 anos, mais escolarizados e com experiências regulares no mercado de trabalho. 345 MARTINS, H. H. T. S. (2000). “A juventude no contexto da reestruturação produtiva”. In: ABRAMO, H. W.; FREITAS, M. V.; SPÓSITO, M. P.(Org.). Juventude em Debate, p. 22. São Paulo: Cortez. MARTINS, H. H. T. S. (2004). A DIFÍCIL TRANSIÇÃO. Análise das trajetórias ocupacionais de jovens operários metalúrgicos. In: Ladislau Dowbor et. al. (orgs). Desafios do trabalho. Petrópolis, Rio de Janeiro: Ed. Vozes, pp. 169-186. 346 Idem. 
sindicato, não gostam de política -; a única preocupação visível diz respeito à ameaça de perda do emprego. Que futuro é possível para esses jovens? Que alternativas eles podem ter?

Assim, se constituiu um campo de experiências da juventude entre educação, trabalho e sua ausência, onde os jovens constróem suas experiências atuais e projetam o futuro. Segundo Pochmann ${ }^{347}$, as expectativas quanto à escola, a busca por cursos de qualificação e a participação em projetos sociais de transferência de renda podem ser analisados a partir desse contexto de incertezas quanto ao futuro numa sociedade em que mudou o padrão de inserção no trabalho.

Nesse contexto, os processos de transição para vida adulta compreendidos como passagem linear da família à escola e desta ao trabalho e formação de um novo lar, já não correspondem à realidade. A passagem para vida adulta acontece em meio às várias mudanças sociais, principalmente as transformações na dinâmica do mercado de trabalho. As trajetórias dos jovens se tornam diversificadas, ou seja, seu percurso de vida acaba sendo marcado por projetos que se interrompem ou são retomados.

A expansão do sistema educacional foi capaz de abrir as portas para as crianças mais pobres. Por outro lado, não tem sido capaz de mantê-las abertas. Percebe-se que não houve, paralelamente, suficiente melhora nos níveis de eficiência do sistema escolar, capaz de responder às demandas pedagógicas dessas crianças. Madeira ${ }^{348}$ ressaltou a importância que tem a definição de políticas públicas específicas, orientadas para aumentar os níveis de retenção no sistema, mais do que a simples expansão quantitativa da oferta de vagas nas escolas.

O sistema educacional está longe de atender às necessidades de qualificação requeridas pelo mercado, seja devido à baixa qualidade de ensino, ou ao forte atraso

347 POCHMANN, M. (1998). A inserção ocupacional e os empregos dos jovens. São Paulo: Associação Brasileira de Estudos do Trabalho. 348 MADEIRA, F. R. (1993). Pobreza, Escola e Trabalho: convicções virtuosas, conexões viciosas. São Paulo em Perspectiva, 7(1): 70-83, janeiro/março. 
escolar médio, que faz com que elevada proporção de jovens deixem a escola sem completar o ensino fundamental. É importante aplicar mecanismos de apoio e incentivos à permanência e/ou volta à escola de adolescentes e jovens com baixa escolaridade. Também se identifica a necessidade de implementar iniciativas voltadas para a educação básica, de forma a solucionar o problema das repetências, atraso e abandono escolar. Por fim, é fundamental que se implante um sistema público de educação de jovens que permita a articulação com o mercado de trabalho.

Para tanto, torna-se necessário articular as políticas do sistema público de emprego e de assistência social com o sistema escolar. Sugere-se apoiar as famílias mais pobres, de forma coordenada, por meio dos vários programas de governo voltados para a juventude, conjugando-os com as ações do sistema Público de Emprego e Renda - os programas de Formação Profissional e Intermediação de Mão-de-Obra. A escola deve ser destacada como espaço privilegiado de diagnóstico das carências da população mais pobre, transformando-se num investimento de formação e informação para as famílias.

O modelo de políticas de juventude no Brasil tende a padronizar as transições dos jovens para a vida adulta - definindo escolaridades mínimas, formação profissional, políticas de emprego, na medida em que os jovens parecem se enquadrar cada vez menos nessas iniciativas. As políticas pressupõem uma transição linear para a vida a adulta, que se iniciaria com a conclusão da escolaridade e a inserção em uma atividade profissional duradoura. $\mathrm{Na}$ verdade, as trajetórias dos jovens entrevistados mostraram-se incertas frente a um mercado de trabalho sob intensas transformações.

Com a mudança na estrutura do mercado de trabalho passou-se a ter menos emprego tradicional, isto é, emprego formal a tempo completo, único por toda vida. Existem ocupações temporárias, intercaladas por períodos de inatividade e desemprego; mudanças contínuas dos requerimentos de qualificação e obsolescência rápida de 
competências, o que exige formação continuada e resulta em trajetórias profissionais não-lineares. Essas mudanças demandam níveis crescentes de escolaridade e flexibilidade, através de mecanismos de formação continuada.

Os programas supõem também uma visão homogênea sobre os jovens pobres, como se suas expectativas e modos de viver a juventude estivessem a princípio determinadas pela sua situação socioeconômica. No entanto, é possível perceber diferentes perspectivas de vivência quanto à juventude, que conformam também vários sentidos da idéia de inserção.

\subsection{Condição dos idosos}

O presente subitem procura abordar a condição dos trabalhadores informais na velhice. A questão da experiência no trabalho informal durante a velhice chamou a atenção ao longo da pesquisa. Foram encontrados trabalhadores com idade avançada, acima de $60 \operatorname{anos}^{349}$, em todas as ocupações. Alguns indivíduos com mais de 70 anos continuavam ativos, apesar da exigência de esforço físico intenso, jornadas prolongadas de trabalho ${ }^{350}$, riscos de acidentes e violência enfrentados no trabalho.

Surgiram muitos questionamentos sobre a sua permanência dessas pessoas no mercado. Fez-se necessário voltar a atenção ao processo de envelhecimento, na medida em que foi constatado o aumento na taxa de idosos e a redução do número de

\footnotetext{
349 A Organização Mundial da Saúde (OMS) define os 60 anos de idade como marco da entrada na velhice. Esse limite é valido para os países em desenvolvimento, subindo para 65 anos de idade nos países desenvolvidos. IBGE (2002). Perfil dos Idosos Responsáveis pelos Domicílios no Brasil, 2000. Estudos \& Pesquisas, $n^{\circ}$ 9, Rio de Janeiro.

350 Homens e mulheres idosos têm jornadas de trabalho mais longas no meio urbano do que no rural: $72 \%$ dos homens idosos no meio urbano têm jornada acima de 40 horas semanais, ao passo que no meio rural são 67\%; das mulheres, $40 \%$ têm jornadas acima de 40 horas semanais nas cidades, contra $26 \%$ no campo. Citado por: WAJNMAN, Simone et alli. (2004). Os idosos no mercado de trabalho de trabalho: tendências e consequeências. In: CAMARANO, Ana Amélia (org.) Os novos idosos brasileiros: muito além dos 60 ? Rio de Janeiro: IPEA.
} 
nascimentos na população mundial a partir da década de 60. Esse fenômeno foi observado de maneira acentuada nos países em desenvolvimento, embora o contingente fosse proporcionalmente inferior ao encontrado nos países desenvolvidos.

As estimativas ${ }^{351}$ para os próximos 20 anos indicam que a população idosa pode exceder 30 milhões de pessoas até o final de 2020, chegando a representar quase $13 \%$ da população do Brasil. Segundo o Censo 2000, o peso relativo da população idosa em 1991 representava 7,3\% do total, enquanto em 2000 compreendia 8,6\%. Nesse período, o número de idosos aumentou em quase 4 milhões de pessoas, fruto do crescimento vegetativo e do aumento da esperança de vida.

O processo de urbanização, o desenvolvimento tecnológico e científico nas áreas da biologia e medicina, a assistência a saúde da população idosa e melhorias nas condições de vida contribuem para o aumento da expectativa de vida para $71 \operatorname{anos}^{352}$ no Brasil em 2003. As mudanças nas condições de saneamento básico dos domicílios foram importantes e contribuíram para o bem-estar e saúde dos moradores. Segundo o Censo Demográfico $2000^{353}, 56,8 \%$ dos domicílios cujos responsáveis eram idosos apresentavam saneamento adequado, com escoadouros ligados à rede geral ou fossa séptica. Esses lares eram servidos de água proveniente da rede geral de abastecimento e tinham o lixo coletado direta ou indiretamente pelos serviços de limpeza.

Apesar das melhorias nas condições de moradia, devem-se considerar as disparidades regionais encontradas: enquanto na Região Sudeste cerca de $80 \%$ dos domicílios com responsável idoso possuíam saneamento adequado, esta proporção

351 IBGE (2002).

$352 \mathrm{Em}$ 2003, a esperança de vida estimada ao nascer no Brasil, para ambos os sexos, subiu para 71,3 anos. Foi um aumento de 0,8 anos em relação à de 2000 (70,5 anos). Mas o patamar desse indicador poderia ser superior em 2 ou 3 anos, não fosse o efeito das mortes prematuras de jovens por violência. O Brasil, por algum tempo experimentou declínios nas taxas de mortalidade em todas as idades. Mas, a partir de meados dos anos 1980, as mortes associadas às causas externas (violência) passaram ter um papel de destaque, desfavorável, sobre a estrutura por idade das taxas de mortalidade, particularmente dos adultos jovens do sexo masculino.Ao considerar que no Japão a vida média já é superior a 81 anos, a esperança de vida no Brasil de pouco mais que 71 anos ainda é relativamente baixa. E, de acordo com a projeção mais recente da mortalidade, somente por volta de 2040 o Brasil estaria alcançando o patamar de 80 anos de esperança de vida ao nascer. (Ver www.ibge.gov.br em População / Tábuas Completas de Mortalidade). A esperança de vida ao nascer de 71,3 anos coloca o Brasil na $86^{\mathrm{a}}$ posição no ranking da ONU, considerando as estimativas para 192 países ou áreas no período 2000-2005 (World Population Prospects: The 2002 Revision; 2003). 353 IBGE (2002). 
atingia apenas $24 \%$ dos domicílios da Região Norte. Permanecia, portanto, um número considerável de idosos vivendo em domicílios com saneamento parcialmente adequado ou inadequado, fato que interferia na sua qualidade de vida e saúde.

A permanência de pessoas com mais de 60 anos no mercado de trabalho foi percebida como um prolongamento da vida produtiva que, na maioria das vezes, não ocorre por opção. Segundo Camarano et alli $^{354}$, alguns idosos aposentados ou sem aposentadoria, com menor nível de escolaridade e baixa qualificação encontram no trabalho informal, principalmente nos Serviços, Comércio e na Agricultura, um meio de obter renda para complementar o valor insuficiente da aposentadoria ${ }^{355}$ ou benefício $^{356}$, ou de conseguir um mínimo de rendimento para o próprio sustento ou da família. A maioria dos idosos está nas posições de conta-própria e sem-remuneração, principalmente as mulheres do meio rural. Em meu estudo a maioria dos idosos $\operatorname{aposentados}^{357}$ recebe o valor de um salário mínimo. Para outros, que não recebem qualquer benefício, a inserção ou reinserção na informalidade é a única maneira de

\footnotetext{
354 Camarano et al.(1999). Como vai o idoso brasileiro?. Texto Para Discussão, n 681, Rio de Janeiro: Instituto de Pesquisa Econômica Aplicada(IPEA), pp.3137. http://www.ipea.gov.br . Consulta realizada no dia 09/05/2009.

355 Aposentadoria por Idade - A aposentadoria por idade é concedida a homens com mais de 65 anos e mulheres com mais de 60 anos de idade desde que tenham cumprido o período de carência, isto é, o período mínimo de contribuições mensais. No caso de trabalhadores rurais (segurados especiais) a idade para requerer a aposentadoria é de 60 anos para o homem e 55 para a mulher e é preciso comprovar o trabalho no campo pelo mesmo período da carência. Para aqueles que se inscreveram na Previdência Social a partir de 25/07/1991, o período de carência é de 180 meses, já aqueles que se inscreveram antes devem respeitar a Tabela Progressiva de Carência. A aposentadoria por idade é irreversível e irrenunciável, isto é, depois que receber o primeiro pagamento, o segurado não poderá desistir do benefício. http://previdenciasocial.gov.br Consulta realizada em 26/05/2009 356 Benefício de Prestação Continuada da Assistência Social - BPC-LOAS ao idoso e à pessoa com deficiência. O Benefício de Prestação Continuada da Assistência Social - BPC-LOAS, é um benefício da assistência social, integrante do Sistema Único da Assistência Social - SUAS, pago pelo Governo Federal, cuja a operacionaliização do reconhecimento do direito é do Instituto Nacional do Seguro Social - INSS e assegurado por lei, que permite o acesso de idosos e pessoas com deficiência às condições mínimas de uma vida digna. QUEM TEM DIREITO AO BPC-LOAS: Pessoa Idosa - IDOSO: deverá comprovar que possui 65 anos de idade ou mais, que não recebe nenhum benefício previdenciário, ou de outro regime de previdência e que a renda mensal familiar per capita seja inferior a $1 \frac{1}{4}$ do salário mínimo vigente. Pessoa com Deficiência - PcD: deverá comprovar que a renda mensal do grupo familiar per capita seja inferior a $1 / 4$ do salário mínimo, deverá também ser avaliado se a sua deficiência o incapacita para a vida independente e para o trabalho, e esta avaliação é realizada pelo serviço de pericia médica do INSS.

357 Em termos de tendências recentes, deve ser ressaltado o expressivo crescimento da proporção de aposentados entre os idosos economicamente ativos, como decorrência da ampliação da cobertura previdenciária pós-Constituição de 1988. Entre 1981 e 2001 a proporção de aposentados acima de 60 anos de idade cresceu de $49 \%$ para $68 \%$ no meio urbano e de $50 \%$ para $92 \%$ no rural. O crescimento da cobertura previdenciária, principalmente rural, não teve impacto sobre a atividade econômica, ou seja, o benefício da aposentadoria, enquanto se reverteu em um importante instrumento de geração de renda familiar e combate À pobreza, aparentemente não gerou nenhum incentivo ao afastamento do trabalho. Wajnman, S.; Oliveira, A. M. H. C. de; Oliveira, E. L. de (2004). Os idosos no mercado de trabalho: tendências e consequencias. In: Ana Amélia Camarano (orgs). Os novos ídolos brasileiros muito além dos 60? Rio de Janeiro: Instituto de Pesquisa Econômica Aplicada (IPEA), pp.454-479. . http://www.ipea.gov.br. Consulta realizada em 10/05/2009.
} 
continuar na luta pela sobrevivência - sendo este o motivo mais comum ouvido dos trabalhadores desta pesquisa para justificar o trabalho em idade avançada.

A reinserção em atividades informais se deve principalmente à falta de oportunidades de emprego, ou ainda à falta de empregos para pessoas de idade. Assim, a permanência dos mais velhos no mercado de trabalho indica que se recorre cada vez mais à alternativa do trabalho irregular ou precário e ao prolongamento das jornadas de trabalho. Tal situação se intensifica com a crescente desregulamentação do mercado.

Os motivos que levam ao prolongamento da vida produtiva e à permanência dos mais velhos no trabalho incluem a responsabilidade pela família ou domicílio; ter que contribuir com a renda familiar ${ }^{358}$; e uma opção individual por manter uma atividade produtiva, como forma de ocupar o tempo livre. As oportunidades de trabalho encontradas pelos idosos têm características específicas em relação aos mais jovens. As atividades informais de baixa renda correspondem a uma situação de classe social, isto é, a classe trabalhadora pobre no mercado de trabalho.

A possibilidade de desfrutar o relativo tempo livre na velhice depende principalmente das condições econômicas. Grande parte dos aposentados entrevistados afirmou a necessidade de continuar trabalhando devido ao valor reduzido dos benefícios previdenciários. Camarano ${ }^{359}$ apontou que "parte expressiva da população idosa parecia pouco sensível à aposentadoria ao contrário do que ocorre em quase todo o mundo" e que "o fato de o aposentado voltar ao mercado de trabalho era bem característico da sociedade brasileira". A autora ressaltou que essa situação era incomum em relação aos países desenvolvidos e destacou que em várias línguas, aposentadoria quer dizer "retiro", e é muitas vezes, utilizada como instrumento de regulação do mercado de

358 Entre os idosos que coabitam com outros familiares, tanto o valor proveniente da aposentadoria quanto a do trabalho, chega a representar quase $60 \%$ do total da renda das famílias urbanas e quase $70 \%$ das rurais. Idem, p. 478. 359 Op. cit. (2004). Vide também CAMARANO, A. A. (2001). O Idoso Brasileiro no Mercado de Trabalho. Texto para Discussão, n 830 , Rio de Janeiro: IPEA, p. 3 . 
trabalho. A volta do aposentado ao mercado de trabalho é uma característica muito particular da sociedade brasileira.

A economista e demógrafa ${ }^{360}$ também destacou um aumento na participação da PEA idosa no total da PEA brasileira: em 1977, 4,5\% da PEA brasileira eram compostos por idosos. A proporção dobrou, tendo atingido 9\% em 1998. Considerandose apenas o efeito das tendências demográficas, ou seja, do envelhecimento populacional, é possível esperar um crescimento intenso desse contingente, que tem chances de compor 13\% da PEA brasileira no não de 2020. Estamos nos referindo, portanto a um contingente relativamente expressivo.

A expectativa de vida da população, o crescente empobrecimento, o baixo valor da aposentadoria e a perda de direitos da classe trabalhadora aparecem como as principais causas do fenômeno do idoso no mercado de trabalho. Dessa maneira, a condição de precariedade social e os maiores gastos com saúde - por exemplo, com planos privados e aquisição de medicamentos para o próprio aposentado e/ou para o seu cônjuge - têm obrigado muitos aposentados a voltarem ao mercado de trabalho.

Segundo os dados do IBGE (Censo 2000), mais de um terço da população da população com mais de 60 anos no Brasil ainda trabalhava em 1999. Os indicadores sociais de 1999, também do IBGE, mostram que 47,1\% das pessoas com idade entre 60 e 64 anos ainda desenvolviam atividade remunerada, sendo $25,5 \%$ a taxa dos maiores de 65 anos na mesma situação. Isso significa que, no Brasil, grande parte da população idosa em idade de aposentadoria ainda precisa trabalhar.

Os trabalhadores aposentados continuarão disputando vagas com os mais jovens no mercado de trabalho, contribuindo para aumentar as taxas de desemprego. Partindo desta perspectiva, poderíamos supor que a condição de miserabilidade e pobreza vivida 
por grande parte da população brasileira é a principal causa do fenômeno do trabalho na velhice, seja entre os aposentados ou aqueles que não tiveram chance de obter esse direito. A miséria vivida pelos aposentados ou idosos sem aposentadoria que ainda precisam trabalhar é, na verdade, reprodução da situação de precariedade vivida por eles ao longo da vida, com a diferença de que ela se exacerba ainda mais na velhice ${ }^{361}$.

A aposentadoria é vista como uma renda garantida por direito e destinada à sobrevivência dos idosos e de suas famílias, que muitas vezes necessita ser complementada por outras fontes. Sabemos que, na realidade, a preservação do valor real dos salários não ocorre na aposentadoria. Receber o benefício não significa ficar livre do trabalho, receber um "prêmio" ou até mesmo um "castigo", na medida em que pode significar o fim da vida produtiva e a exclusão social. Faz-se necessário destacar que o benefício não significa um favor concedido pelo Estado, mas sim um direito conquistado pela classe trabalhadora explorada pelo capital.

O Censo $2000^{362}$ verificou que $62,4 \%$ dos idosos eram responsáveis pelos domicílios brasileiros. Observou-se um aumento em relação a 1991, quando os idosos responsáveis representavam 60,4\%. É importante destacar que em 2000, no conjunto dos domicílios brasileiros, 8.964.850 tinham idosos como responsáveis, representando $20 \%$ do contingente total. Em 1991, a proporção ficava em torno de 18,4\%. A maioria dos idosos era do sexo masculino, com idade média em torno de 69,4 anos, em 2000.

O fenômeno da velhice, em meu estudo, foi percebido com maior frequência entre os trabalhadores por conta-própria: catadores de materiais recicláveis e vendedores ambulantes. Nas ocupações de colhedores de laranja e pescadores de lagosta foram encontrados menos idosos. Talvez esse fato tenha a ver com a relação de assalariamento. Nestas atividades, os trabalhadores dependiam da "boa vontade" dos

361 PEIXOTO, Clarice (2004). Aposentadoria: retorno ao trabalho e solidariedade familiar. In: PEIXOTO, Clarice (org.). Família e Envelhecimento. Rio de Janeiro: FGV, 2004, pp. 57-84., p. 60. 362 IBGE (2002). 
"turmeiros", "gatos" ou mestres para serem selecionados. Apesar da experiência e do "saber fazer" adquirido durante longos anos de prática serem importantes nas ocupações tradicionais, a força física e a agilidade, características atribuídas aos jovens, eram os principais critérios para escolha.

As transformações decorrentes da modernização, a automação e a reestruturação dos processos produtivos geradores de riqueza contribuíram para que os trabalhadores idosos, considerados lentos, tivessem cada vez menos espaço no mercado. Essas mudanças no processo de trabalho contribuíram para a formação de culturas organizacionais e profissionais desfavoráveis aos idosos. Para tanto, prevaleciam os valores relacionados à juventude, como precisão, atualização, agilidade e dinamismo, entre outros ${ }^{363}$.

Os poucos idosos escolhidos eram alocados na função de mestres, para ensinar a tarefa aos mais jovens - caso da pesca -, ou por amizade pessoal - o que observamos na colheita da laranja. Assim, a maioria dos trabalhadores com idade mais avançada era excluída das ocupações com melhores rendimentos e garantias. Sendo assim, restavam apenas as atividades por conta-própria ou autônomas. Na maioria dos casos, os mais velhos conseguiam ser assalariados sem carteira de trabalho devido à consideração e ajuda de pessoas conhecidas.

Percebeu-se que a rede de sociabilidade formada por familiares, amigos e vizinhos era fundamental para a inserção e permanência na atividade informal. Ao serem indagados, os idosos disseram ter começado um negócio próprio, ou a trabalhar como assalariados sem carteira por orientação e indicação de pessoas conhecidas. Era comum receberem auxílio de familiares ou colegas para o desenvolvimento do trabalho, seja para carregar peso, para se protegerem em caso de intervenção da Guarda

363 PERES, Marcos (2002). Trabalho, idade e exclusão: a cultura organizacional e as imagens sobre o envelhecimento. Dissertação (Mestrado em Sociologia). Instituto de Filosofia e Ciências Humanas, Universidade de Campinas. 
Municipal e apreensão de mercadorias ilegais no momento do "rapa", ou para conseguirem pontos privilegiados de venda nas ruas, entre outras situações.

Notou-se durante minha pesquisa que, na pesca da lagosta, o desgaste físico e psíquico fazia com que muitos trabalhadores não conseguissem mais desenvolver a atividade após os 50 anos de idade. A aparência física de um pescador após 30 anos no mar é a de alguém bem envelhecido. Na fala de um dos entrevistados, ficou claro o desalento e a preocupação com o futuro. Percebeu-se inclusive que a qualificação, o "saber fazer" e o conhecimento prático da tarefa aprendida em muitos anos de atividade e o aprendizado adquirido de maneira tradicional, isto é, na relação de pai para filho, eram considerados importantes por poucos mestres (chefes da equipe da operação), em especial pelos mais experientes e com mais tempo na profissão. Um pescador de 55 anos disse o seguinte:

José

Olha, aqui a gente só serve quando dá prá trabalhar... Tem que ter força, saúde, senão os mestres não escolhem mais a gente. Eles pegam os mais fortes, que não têm problema de saúde e que não cria encrenca. $O$ trabalho é tão puxado que a gente não aguenta por muitos anos. Dá pra trabalhar bem até uns 50 anos. Alguns passam dos 50. Depois a gente não aguenta, está cansado, com problemas na coluna. Agora tem dono de barco que gosta de levar pescador com experiência (eram os pescadores com mais de 50 anos, sendo que alguns possuíam de 58 a 60 anos) que conhece o mar, o trabalho... Pelo menos um deles vai no barco. 
Enquanto os pescadores de lagosta aguardavam a aposentadoria especial ${ }^{364}$, outros trabalhadores, como os catadores de materiais recicláveis, vendedores ambulantes e colhedores de laranja tiveram carteira de trabalho assinada por pouco tempo e não continuaram contribuindo para a Previdência Social. Depois de sofrerem os desgastes físicos e mentais intensos em várias atividades na informalidade, se encontravam em idade avançada, sem qualquer benefício e com doenças adquiridas ou agravadas pela atividade de trabalho. Eram obrigados a trabalhar mesmo nessas condições para ajudar no sustento das famílias, em geral composta por várias pessoas desempregadas. Uma colhedora de laranja de 60 anos indicada pelo Programa de Saúde da Família da Unidade Básica de Saúde da Vila dos Remédios em Limeira (São Paulo), comentou o seguinte:

Ana

Eu sempre trabalhei na lavoura, desde criança. Comecei pequena, com 7 anos. Trabalhava com meus pais na plantação de café. Depois fui trabalhar prá outros. Trabalhei na lavoura de café, na plantação de mandioca, milho e na colheita da laranja e fazendo enxerto de mudas. Casei e continuei trabalhando quando dava. Tive nove filhos, um depois do outro. Sempre trabalhei na lavoura. Há muitos anos tive carteira de trabalho assinada durante cinco anos. Foi quando trabalhei no barracão, separando as laranjas. Foi só aí. Fiquei doente com o tempo. Hoje tenho pressão alta, artrite, reumatismo, dores na coluna, pernas e braços, dores pelo corpo todo. Tem dia que não fico de pé de tanta dor. Faço tratamento no Posto de Saúde aqui perto de casa. Eles vem aqui em casa, trazem remédio, me ajudam muito. Queria me aposentar por idade. Mas ainda não consegui. Estão

364 A aposentadoria especial é um benefício concedido aos trabalhadores assegurados pela Previdência, que tenham trabalhado em condições prejudiciais à saúde. Nessas condições, o tempo de trabalho necessário para se aposentar diminuiu, variando de acordo com o agente ao qual o trabalhador foi exposto. A comprovação dessas condições especiais deve ser feita em um formulário preenchido pela empresa empregadora, com base em Laudo Técnico de Condições Ambientais de Trabalho (LCTA) expedido por médico do trabalho ou engenheiro de segurança do trabalho. Fonte: www.previdenciasocial.gov.br (consulta dia 26 de maio de 2009). 
vendo a papelada. Tenho que trabalhar. Tem muita gente em casa (ao todo 12 pessoas)... Filhos, noras, genros e netos. Só tem três trabalhando, comigo quatro. Agora estou na roça, fazendo bico, rastelando laranja, colhendo as laranjas caídas. Consegui porque sou muito conhecida no Bairro dos Remédios. Os "turmeiros" arranjam trabalho pra mim. Não consigo mais carregar sacolas (com laranjas) pesadas. Só posso carregar pouca coisa. Os colegas ajudam quando preciso. Se eles acabam a parte deles e eu estou rastelando as laranjas, eles ajudam a colher e encher as sacolas. Consigo ganhar uns R\$300,00 a 350,00. Ajudo meu filho que tem carroça. Quando dá, saio com a carroça catando material de reciclagem nas horas vagas. Carrego pouca coisa. Não aguento peso. Consigo ganhar R\$ 150,00 por mês...

$\mathrm{Na}$ lavoura foram encontrados alguns trabalhadores idosos assalariados. As mulheres costumavam "rastelar", varrer as laranjas e outras frutas que estavam no chão e preparar os enxertos de mudas nos barracões. Os homens executavam tarefas que exigiam força física apesar da idade, por exemplo, no plantio e colheita. O trabalho de rastelar laranja e fazer enxertos possibilitava um rendimento menor às mulheres. Segundo o Censo 2000 (IBGE), as mulheres idosas costumavam ter nível de escolaridade e rendimento menores que os homens. Foram encontrados vários idosos sem aposentadoria ou qualquer benefício. Um aspecto que chamou atenção foi a falta de informação sobre os direitos trabalhistas e previdenciários. A colhedora citada acima comentou o seguinte:

Ana

Eu não sei como conseguir aposentadoria por idade. Estou pedindo ajuda para a moça do UBS (Unidade Básica de Saúde) que vem em casa me ver. Ela é do Programa de Saúde da 
Família. Eu nem tenho documento direito. Perdi tudo numa enchente, a casa ficou cheia d'água. Eu tive carteira há muitos anos e por pouco tempo. Agora estou com reumatismo e não posso mais trabalhar. Preciso do dinheiro... Então continuo rastelando laranja ou catando lixo na rua. Não sei até quando eu aguento.

Esses trabalhadores tiveram pouco ou nenhum contato com entidades de representação de classe em suas trajetórias profissionais. Não possuíam o hábito da leitura de jornais e revistas. Tiveram contato com os meios de comunicação de massa, como a televisão, há pouco tempo. A memória costumava falhar quando descreviam sua trajetória profissional. Não conseguiam se lembrar de datas e tempo trabalhado nas diversas ocupações no decorrer da vida produtiva. Sempre relacionavam o trabalho desenvolvido com algum acontecimento, como o nascimento dos filhos, a morte de pessoa na família, a mudança de cidade, a crise econômica, o desemprego, entre outros.

Outra questão importante é a quantidade expressiva de trabalhadores que não sabiam escrever, apenas assinar o próprio nome. O analfabetismo funcional ${ }^{365}$ era comum na população idosa. O Censo de 2000 (IBGE) mostrou que 34,6\% dos que têm mais de 60 anos eram analfabetos. Sendo assim, o contingente de idosos analfabetos era expressivo, representando cerca de 5,1 milhões de pessoas ${ }^{366}$. A precariedade do sistema educacional público, que era maior na época em que esses idosos estavam em "idade escolar”, sem dúvida dificultou seu acesso à educação.

A precariedade do sistema educacional público, supostamente maior na época em que esses idosos estavam em "idade escolar", sem dúvida dificultou seu acesso à educação. O analfabetismo é um problema social grave que impede qualquer acesso à

365 Segundo a UNESCO, o analfabetismo funcional se observa em indivíduos com menos de quatro anos de estudo ao longo da vida. 366 IBGE (2002). 
vida cultural e a um conjunto de informações necessárias ao exercício da cidadania ${ }^{367}$. O Estatuto do Idoso, de maneira surpreendente, não trata do problema do analfabetismo em nenhum dos itens referentes à educação. Ao contrário, ignora-o totalmente.

Podemos citar, por exemplo, o Art $^{\circ}$ 20, Capítulo 20 do Estatuto do Idoso (2003): “O idosos tem direito à educação, cultura, esporte, lazer, diversões, espetáculos, produtos e serviços que respeitem sua peculiar condição de idade". A questão da educação fica diluída entre outros direitos. Deveria haver maior destaque à educação na medida em que esta é o veículo para a cidadania. Sem acesso a programas de alfabetização ou educação fundamental, pouco se poderá usufruir a cultura, o lazer e o esporte. A educação nos níveis iniciais e básicos é indispensável para a compreensão mínima do universo cultural que nos cerca ${ }^{368}$.

Os idosos entrevistados lamentavam a falta de oportunidades e condições para estudar quando ainda eram jovens. A maioria não demonstrou interesse em participar dos programas de educação de adultos. Alegava falta de tempo por conta da jornada prolongada de trabalho; pouca disposição física; memória "fraca"; e dificuldade de acesso à escola, entre outros motivos. Os idosos diziam que mesmo com pouco estudo, sabiam calcular o valor que deveriam receber no final do mês, o valor das mercadorias e o lucro obtido através das vendas sobre a quantidade produzida. Percebeu-se assim a importância do conhecimento prático e do "saber-fazer" adquiridos no cotidiano para permanecer no mercado de trabalho.

A maioria dos trabalhadores de idade avançada, como foi possível identificar em meu estudo, tentou após longo período sair da agricultura, que não pagava bem e quase não oferecia trabalho. Quando crianças e jovens, essas pessoas tinham participado de sistemas de trabalho familiar ou assalariado. Após a experiência de trabalho rural,

367 PERES, Marcos Augusto de Castro. (2007). Velhice, Trabalho e Cidadania: as políticas da terceira idade e a resistência dos trabalhadores idosos à exclusão social. Tese de Doutorado em Educação. Faculdade de Educação da Universidade de São Paulo, São Paulo, 2007, 361p. (p. 345). 368 Ibidem, p. 346 
alguns conseguiram inserção nos setores de indústria, serviços e comércio sob exigência de um mínimo de escolaridade.

A maior parte dos entrevistados conseguiu registro em carteira de trabalho por certo tempo. Na década de 90, eles encontraram emprego nas funções de motorista de trator; vigia de obra; ajudante de pedreiro na construção civil; operador de ponte rolante na indústria de transformação; diversas funções na indústria têxtil; porteiro; e vigia na indústria de açúcar e álcool, para citar algumas. Após a crise econômica e com a desaceleração da economia, a flexibilização das relações de trabalho e a terceirização, esses trabalhadores foram demitidos. Após várias tentativas frustradas de reinserção no mercado formal, foram obrigados a recorrer aos trabalhos informais e "bicos".

As estratégias de sobrevivência encontradas, entre poucas opções, foram voltar para a lavoura; abrir um pequeno negócio por conta-própria; trabalhar como ajudante, principalmente nos setores de serviço, comércio e construção civil. Sendo assim, demitidos após 20 anos como assalariados com carteira de trabalho, alguns trabalhadores deixavam de contribuir para a Previdência Social, com o argumento de que não "sobrava dinheiro" para manter a contribuição. O pouco que conseguiam ganhar em subempregos era gasto com itens básicos de sobrevivência, como alimentação, aluguel, conta de luz, água e remédios. Cláudio retornou à agricultura, como colhedor de laranja aos 60 e Mário, aos 58 anos. Os colhedores declararam:

\section{Cláudio}

Fiquei na lavoura até 24 anos. Ganhava pouco, quase nada... Primeiro trabalhei com meu pai, na família. Depois fui trabalhar pra outra pessoa... Foram várias, tudo no campo. Queria melhorar de vida, ganhar mais, pensar no futuro. Consegui um trabalho de motorista de trator numa empresa de construção civil. Fiquei 16 anos. Aí fui mandado embora. Depois trabalhei 
sem carteira, como servente de pedreiro, por uns seis anos. A obra acabou. Eu tinha 48 anos e fui colher laranja. Fiquei uns quatro anos. Aí um amigo me chamou para trabalhar numa obra. Fui vigia e servente. Fiquei oito anos, quatro registrado. A obra acabou. Com 60 anos, voltei a colher laranja. É trabalho pesado, mas fazer o quê? É o que tem prá fazer. Estou nessa há quatro anos. Só agora eles me registraram. Faz um ano que registraram. Não mudou nada. Abaixaram o preço do peso da laranja. Antes ganhava mais.

\section{Mário}

Comecei com onze anos na roça com minha família. Plantei milho, café e soja. Depois meu pai vendeu o sítio porque estava dando prejuízo. Fiquei 20 anos na lavoura. Depois (31 anos) trabalhei como operador de ponte rolante. A empresa passou por processo de terceirização e fui contratado por empreiteiros. Antes ganhava $\mathrm{R} \$ 800,00$ e passei a ganhar a metade, $\mathrm{R} \$ 400,00$ pelo mesmo serviço. Pedi para sair e fui (34 anos) ser porteiro, guarda e vigia de uma indústria de álcool e açúcar, na Refinaria União. Fiquei quinze anos. A empresa também terceirizou vários setores. Preferi ser demitido. Aí trabalhei como ajudante de pedreiro e vigia de obra. Fiquei uns três anos registrado. A obra acabou e eu voltei para a (colheita da) laranja. Tinha 54 anos na época. Depois disso, fiz vários "bicos", plantava árvores em um sítio (um ano), plantei grama (um ano), trabalhei na feira durante 4 meses carregando caminhão e como vendedor na banca. Ia pulando de um trabalho prá outro. Acabava um e eu pegava outro, o que aparecia, pegava. Aos 58 voltei a colher laranja. Estou nessa uns sete anos, quando precisa eu dirijo a Kombi que transporta o pessoal que vai prá roça colher.

Questionados, todos os entrevistados desta pesquisa responderam que gostariam de receber aposentadoria. Os pescadores de lagosta eram segurados especiais com 
direitos de se aposentar com menos tempo de trabalho. Entre os entrevistados (80), apenas três catadores de materiais recicláveis, um colhedor de laranja e cinco camelôs continuaram contribuindo para a Previdência Social. Sendo assim, apenas 11\% dos entrevistados continuavam contribuindo regularmente para a Previdência. Sabiam da importância, dos direitos de auxílio doença e acidentário e da aposentadoria que receberiam na velhice. Comentaram que queriam a aposentadoria para poder "descansar", "viajar" e ocupar o tempo com lazer, mas devido ao valor baixo sabiam, desde já, que teriam que continuar trabalhando para poder sobreviver.

Os argumentos que justificavam a não-contribuição para a Previdência eram: "não sobrava dinheiro"; que o entrevistado "não queria perder o dinheiro para o governo"; e no caso dos idosos camelôs, que "já tinham muitos gastos com propina para fiscais e seguranças na região”. Existia uma desconfiança em relação ao uso do dinheiro do contribuinte pelo Estado. Desconfiava-se que fosse empregado tanto para proteger seus beneficiários, como nas ações de repressão contra os camelôs e, quanto a isso, os trabalhadores eram irônicos ao dizer que pagavam os impostos e tributos "para apanhar da Guarda Municipal" e lamentar que, ao invés de proteção, eram tratados feitos bandidos e ladrões.

Alguns trabalhadores que haviam tido condições de contribuir reconheciam não ter dado a devida importância ao futuro quando eram jovens e demonstravam arrependimento porque agora estavam envelhecendo sem direito à aposentadoria. Indicavam como motivos a vida atribulada pelo trabalho; as trajetórias incertas; as várias mudanças de atividades formais para informais e vice-versa; e as preocupações com questões práticas do dia-a-dia, que não haviam permitido pensar sobre as condições de vida na velhice. 
Existia entre os mais velhos uma desesperança quanto à perspectiva de receber o benefício. Alguns revelavam não conhecer os procedimentos para receber os direitos, por exemplo, à aposentadoria por idade; havia aqueles cujos documentos pessoais estavam incompletos, como citado acima. O mais preocupante era que os trabalhadores entrevistados nunca ou pouco tinham contribuído para a Previdência. Para ter direito à aposentadoria por idade ${ }^{369}$, era necessário ter cumprido o período de carência, isto é, o período mínimo de contribuições mensais. Por exemplo, para o sujeito solicitar a aposentadoria por idade em 2009, ele teria que ter contribuído 168 meses.

Para alguns idosos, continuar trabalhando depois da aposentadoria significava "ter algo para se ocupar e distrair", ou um meio de manter a sociabilidade, ao invés do "não ter o que fazer" e vivenciar a experiência do vazio e do isolamento, comuns ao fim da vida produtiva. O mais preocupante eram os casos dos idosos arrimos de família, obrigados a se submeter ao trabalho pesado durante jornadas de 12 a 15 horas por dia, em condições precárias.

Alguns eram únicos provedores na casa e outros dividiam as despesas com outros familiares. Eram responsáveis pela alimentação, pagamento de aluguel, luz, água e demais gastos da família, inclusive dos filhos e netos. Ficavam preocupados com o futuro e a falta de perspectiva. Na família de todos entrevistados, uma ou mais pessoas estavam desempregadas. Um colhedor de laranja de 72 anos, aposentado por idade, disse o seguinte:

\section{Geraldo}

$\mathrm{Eu}$ comecei trabalhando aos sete anos na lavoura junto com minha família. Ficava na roça, na plantação de café. Fiquei mais de 30 anos no café sem carteira assinada. Depois fui cortar

\footnotetext{
369 A aposentadoria por idade é concedida a homens com mais de 65 anos e mulheres com mais de 60 anos de idade, desde que tenham cumprido o período de carência. No caso de trabalhadores rurais (segurados especiais), a idade para requerer a aposentadoria é de 60 anos para os homens e 55 para a mulher e é preciso comprovar o trabalho no campo pelo mesmo período de carência. Fonte: www.previdenciasocial.gov.br. Consulta realizada no dia 26 de maio de 2009.
} 
cana. $\mathrm{O}$ trabalho era puxado, pesado mesmo. $\mathrm{O}$ calor e a fumaça (por causa da queimada) incomodavam muito. Fiquei uns 20 anos cortando cana-de-açúcar. Era registrado na carteira mas fui mandado embora, demitido por causa da idade. Não era mais jovem e não conseguia produzir muito. Os mais novos ficavam e os mais velhos eram demitidos. Tentei ir pra construção civil trabalhar como ajudante de pedreiro, mas disseram que prá minha idade não ia dar. O trabalho é pesado, puxado. Estou colhendo laranja há cinco anos. Foi a única coisa que sobrou pra fazer. Preciso trabalhar, o dinheiro da aposentadoria é pouco. Minha esposa está doente e preciso comprar remédios que não tem no posto. Meus filhos já saíram de casa e tem a família deles pra cuidar. Eu preciso me virar. Estou na (colheita da) laranja há sete anos. O 'turmeiro' é muito bom comigo. Os colegas também. Não tenho mais a mesma agilidade e força, meu corpo tá cansado, mas fazer o quê? A gente precisa trabalhar, né! A experiência de vida traz mais calma, cabeça. Hoje trabalho no meu ritmo, paro descanso, faço mais devagar... Mas dá um salário mínimo.

Nos últimos anos, foi constatado aumento no número de domicílios sob responsabilidade dos idosos. Os indicadores revelam certa melhora nos rendimentos médios percebidos pelos responsáveis idosos entre 1991 e $2000^{370}$, principalmente nas zonas rurais do país. Por outro lado, a distribuição dos responsáveis idosos por classes de rendimento ainda se encontra extremamente concentrada nos estratos de renda média, com menos anos de estudo. Houve pequena melhora no aspecto educacional, aumentando a proporção de idosos alfabetizados, embora a média de anos de estudo deste segmento ainda seja baixa, com cerca de $60 \%$ dos responsáveis idosos sendo considerados analfabetos funcionais. 
Entre os vendedores ambulantes, foi encontrado o maior número de aposentados ou trabalhadores idosos que continuavam na ativa. A maioria trabalhava por necessidade e poucos para preencher o tempo e sair de casa. Acostumados com o ritmo de trabalho intenso, não sabiam ficar "parados" ou "sem fazer nada". Não aceitavam a imagem do idoso usando pijama e assistindo televisão, ou dormindo durante o dia. Comentavam que quando ficavam em casa, brigavam com a mulher e os filhos e se estressavam.

$\mathrm{O}$ trabalho era o momento de liberdade e entretenimento. A convivência com colegas e clientes era prazerosa e contribuía para saúde física e mental dos indivíduos. Esses trabalhadores tinham situação econômica estável, com casa própria, filhos independentes e alguma poupança para casos de emergência. Um vendedor ambulante de 78 anos disse o seguinte:

\section{João}

$\mathrm{Eu}$ trabalhei na roça capinando quando criança com minha família. Depois fui trabalhar pra outros na colheita e plantação de frutas. Com 30 anos, fui trabalhar numa padaria e depois em outra. Fui registrado nas duas. Fiquei mais de dez anos fazendo pão, salgados, doces e bolos. Depois, com 40 anos, um pouco mais, eu fui trabalhar como motorista, também registrado. Fiquei nisso por 18 anos. A empresa fechou (falência), mas eu continuei pagando o carnê (da Previdência) para aposentar. Fiz alguns bicos trabalhando prá outros (motorista de perua, transporte escolar etc.). Depois de aposentar, sabia que não queria ficar parado. Gosto de agitação, sempre gostei de trabalhar. Já vinha pensando há tempo em fazer alguma coisa, ter um negócio meu. Não queria trabalhar como motorista por causa do trânsito na cidade. Tinha um dinheiro guardado. Um conhecido falou que vender alimento dava dinheiro. Eu tenho 
parentes em Minas e resolvi montar uma banquinha pra vender queijos, doce de leite, biscoito caseiro, doces em conserva, mel. Hoje recebo o dinheiro da aposentadoria e da venda dos produtos na banca. Não dá tanto dinheiro assim, tem muita gente vendendo também, mas o dinheiro que entra ajuda muito. Dá pra arrumar a casa (reforma), viajar pra Minas para passar 15 dias no final do ano ou alugar uma casa na praia. O próximo passo é trocar o carro por um mais novo.

As atuais políticas públicas voltadas para idosos procuraram contribuir para a redução das desigualdades que marcaram suas trajetórias de vida. O aumento de cobertura dos benefícios assistenciais e previdenciários, tanto rurais quanto urbanos; a equiparação do valor do benefício mínimo ao salário mínimo vigente; e a mudança das condições para elegibilidade aos benefícios rurais eram alguns dos exemplos positivos de diminuição das desigualdades ${ }^{371}$.

Por outro lado, o crescimento da taxa de participação dos idosos levanta importantes discussões sobre a capacidade da sociedade de se adaptar a essa realidade. Percebeu-se que, por um lado, a universalização dos benefícios da seguridade social foi importante na melhoria dos rendimentos dos idosos. Por outro, o aumento no número de idosos provoca fortes pressões no sistema previdenciário e de assistência social. Além disso, o aumento da proporção de idosos vivendo sozinhos levanta questões sobre as condições que devem ser oferecidas a esses idosos, com tendência de vida cada vez mais autônoma ${ }^{372}$.

O sistema previdenciário apresentou várias distorções, além de estar operando no déficit desde 1994. Entre as distorções, cita-se a existência da aposentadoria por tempo de contribuição, que possibilita o acesso ao benefício em idades bastante

371 CAMARANO, Ana Amélia (2006). Mecanismos de proteção social para a população idosa brasileira. Rio de Janeiro: IPEA, Texto para Discussão, $\mathrm{n}^{\circ}$ 1179. $\mathrm{p}$. 17. 
precoces. Levando em consideração a questão do tempo de contribuição e a idade, foram realizadas outras reformas que tiveram por objetivo o adiamento da idade para o requerimento dos benefícios, a redução do valor a receber e o aumento do vínculo entre contribuições e benefícios ${ }^{373}$.

O primeiro objetivo era bastante coerente com o aumento da esperança de vida. Por outro lado, reforçar o vínculo entre contribuições e benefícios significava não levar em consideração as importantes transformações pelas quais o mercado de trabalho tem passado. Parte das gerações mais novas já está experimentando os efeitos da flexibilização desse mercado, bem como a rigidez da nova política de Previdência Social. Ambos afetarão o acesso aos benefícios previdenciários em um futuro próximo e não irão resolver os problemas de financiamento do sistema previdenciário ${ }^{374}$.

Um dos grandes desafios do sistema de seguridade social no tocante à qualidade dos idosos brasileiros do futuro é aumentar a cobertura da atual força de trabalho e manter e ampliar a cobertura dos benefícios não-contributivos. O aumento no número de idosos requer do Estado a criação de mecanismos de apoio para que a família possa manter o seu tradicional papel de protetora.

O mais preocupante são os casos de idosos excluídos do convívio familiar, que vivem em situação de risco. Faz-se necessária a implementação de uma política de assistência social e saúde física e mental a essa população vulnerável, que costuma viver abandonada nas ruas da cidade. Além disso, as redes comunitárias deveriam ser apoiadas para que as pessoas idosas pudessem desenvolver suas vidas num ambiente propício e favorável.

Nessa perspectiva, cada vez mais se tornou importante o tema do envelhecimento e dos incentivos a serem dados sob forma de ações governamentais,

373 Idem, p. 17. 
econômicas, políticas e culturais, que poderiam garantir ao idoso melhor qualidade de vida. $\mathrm{O}$ interesse das pessoas idosas pela continuidade no mercado de trabalho deveria ser realmente uma opção para ocupar o tempo livre, não uma necessidade de luta pela sobrevivência. Após anos de dedicação ao trabalho, sendo contribuintes ou não, os idosos deveriam ter direito às condições de vida decente. 


\subsection{Condições de vida e renda}

\subsubsection{Vendedores ambulantes}

Os vendedores ambulantes entrevistados tinham rendimentos de em média dois a três salários mínimos por mês durante o ano. No período de alta temporada ${ }^{375}$, alguns vendedores ambulantes conseguiam receber mais de quatro salários mínimos. No entanto, é importante ressaltar o número significativo de camelôs que lucravam até dois salários mínimos com as vendas. Durante as entrevistas, os camelôs mais antigos disseram que no passado ganhavam melhor. Hoje, devido ao desemprego, a concorrência aumentou, as mercadorias estão caras, a fiscalização da prefeitura é ostensiva e as lojas e departamentos facilitam a forma de pagamento, vendendo produtos com preços menores. Esses aspectos prejudicam o movimento de compra e venda no comércio informal.

A renda obtida pelos vendedores ambulantes de minha pesquisa está de acordo com as informações do relatório ECINF $2003^{376}$. Segundo o estudo, o rendimento médio mensal de todos os trabalhadores por conta própria é de $\mathrm{R} \$ 623,00$ (2,6 salários mínimos). O rendimento dos homens é superior ao das mulheres. O rendimento médio dos homens assalariados no setor informal, em outubro de 2003 , foi de R\$ 378 (1,6 salários mínimos) ao mês e o das mulheres, $\mathrm{R} \$ 338$ (1,4 salários mínimos). A diferença entre os rendimentos dos homens e das mulheres pode ser explicada pelo menor tempo

375 Datas comemorativas, como o Dia das Mães; Dia dos Pais; Natal; Dia das Crianças; ou períodos de festas, como o Carnaval, por exemplo. 376 Pesquisa sobre economia informal urbana desenvolvida pelo Instituto Brasileiro de Geografia Estatística - IBGE com a colaboração do SEBRAE (Serviço Brasileiro de Apoio às Micro e Pequenas Empresas), 2003. 
de permanência nas atividades por conta-própria das mulheres. As mulheres costumam ser responsáveis também pelos trabalhos domésticos e cuidados com os filhos.

Entre os vendedores ambulantes, vários tinham outros "bicos" para complementar a renda. Costumavam fazer trufas, balas de coco, bolos, doces e salgados em geral por encomenda; costurar vestidos de noiva; fabricar artesanatos para algumas lojas; costurar ou colar peças de roupas para fábricas ou lojas de departamentos; fazer serviços de eletricista, pintor e pedreiro. Essas atividades eram desenvolvidas principalmente nos momentos em que as vendas no comércio popular estavam fracas, isto é, na baixa temporada. Os entrevistados reclamavam por receberem pouco, mas sabiam que o dinheiro ajudava saldar dívidas; comprar remédios para pessoas doentes na família; melhorar as condições de suas barracas, automóveis, carrinhos de cachorroquente ou sorvete; e resolver outros problemas.

O comércio informal nas metrópoles caracteriza-se pela venda de alimentos manuais e industriais ${ }^{377}$; frutas, legumes e verduras; roupas de cama, mesa e banho; roupas femininas e masculinas; calçados; bolsas, mochilas e acessórios; brinquedos; aparelhos eletrônicos; DVDs; perfumaria; relógios; e ferramentas, entre outros produtos. Alguns produtos são de fabricação nacional, outros estrangeiros - que costumam passar por vários intermediários até chegar ao consumidor final.

Nota-se que várias empresas monopolizam a distribuição de determinados produtos nas regiões no país. O preço da mercadoria é menor que no comércio regular devido à sonegação de impostos. Apesar da intervenção da Polícia Federal, o contrabando continua sob o comando de quadrilhas em nível internacional. A repressão sobre os camelôs costuma ser ostensiva e violenta. Esses sujeitos são a parte mais frágil e vulnerável do processo de distribuição das mercadorias. Não podemos esquecer a 
superexploração de trabalhadores no processo de produção, principalmente nos países asiáticos. Fica a questão da responsabilidade e punição dos grandes empresários na cadeia produtiva, dos proprietários das fábricas e até dos intermediários e distribuidores que detêm a maior parte dos valores financeiros.

Ressalto que um número significativo de camelôs entrevistados pagava aluguel ou parcelas de financiamento da casa própria. A maioria morava em bairros que, embora distantes da região central da cidade, possuem boas condições de infraestrutura $^{378}$, transporte e segurança. O tipo de habitação era familiar e acomodava de duas a quatro pessoas em média. Os trabalhadores tinham até dois filhos por casal. As moradias possuíam entre quatro e cinco $\operatorname{cômodos}^{379}$, ou mais. A maioria dos vendedores ambulantes utilizava hospitais públicos e Unidades Básicas de Saúde (UBS) quando necessário. Alguns pagavam convênio médico para ter direito a assistência médica privada. Esses não confiavam no serviço de saúde pública, pois já tinham passado por experiências negativas com esse tipo de atendimento.

Em relação à posição na família dos ocupados em comércio ambulante, percebese que o grupo dominante é o de chefes de família, com tendência crescente no período considerado: de 1985 a 1995, os chefes de família passaram de pouco mais de $40 \%$ para quase $50 \%$ dos ambulantes. Segundo MELO et alli ${ }^{380}$, esse dado indica que um grande número de famílias tem como principal fonte de renda a atividade no comércio ambulante, já que supostamente é o chefe quem as sustenta, enquanto os outros membros, que também trabalham, ficam responsáveis por contribuir com o orçamento doméstico. Dessa maneira, a atividade informal não é procurada meramente como complementação da renda familiar, mas como a principal fonte.

378 A infraestrutura inclui água encanada, iluminação, esgoto, energia elétrica, coleta de lixo e ruas asfaltadas, entre outros serviços e necessidades. 379 Cozinha, sala de estar, quartos e banheiro. 380 MELO, Hildete Pereira de; TELES, Jorge Luiz (2000). Serviços e Informalidade: o comércio ambulante no Rio de Janeiro. Texto para Discussão n 773 , Instituto de Pesquisa Aplicada (IPEA), Rio de Janeiro, dezembro. 
O segundo grupo de maior peso é o de cônjuges, representando cerca de $30 \%$ do total de ocupados no comércio ambulante ao longo do período considerado. Juntamente com os chefes, eles abrangem entre $70 \%$ e $80 \%$ do total de ocupados nessa atividade informal, ressaltando a importância da participação da renda oriunda de atividades ambulantes para o orçamento doméstico.

Percebem-se oscilações na participação do grupo de filhos, ou seja, ocorre um maior fluxo de entradas e saídas de filhos nas atividades de comércio ambulante. Isso confirma que essas atividades não são procuradas apenas para a complementar o orçamento doméstico e que podem ser uma opção de primeiro "emprego" para os filhos, com o objetivo de ganhar experiência e como fonte de renda até que consigam um emprego no mercado de trabalho formal. É importante destacar o fato do comércio ambulante ser cada vez mais o sustentáculo do orçamento doméstico, isto é, o principal meio de vida para muitas famílias inteiras.

Entre os vendedores ambulantes, foi encontrado o maior número de casais que trabalhavam fora de casa e o maior número de esposas que participavam do orçamento doméstico realizando trabalhos dentro e fora de casa - neste caso, as mulheres recebiam valores em torno de um a dois salários mínimos por mês por seu trabalho. Em outros casos, as esposas apenas "ajudavam" os maridos na venda dos produtos. Os homens permaneciam a maior parte do tempo nas barracas e as mulheres estavam presentes nos horários de maior movimento, no almoço e no jantar. Quando os maridos necessitavam se ausentar para pagar contas, fazer compras ou realizar trabalhos temporários em outra atividade, as esposas se tornavam responsáveis pelo comércio. Alguns filhos “ajudavam” o pai nas vendas nos horários em que não estavam estudando, ou no período de férias. Nessas situações, que revelam a existência do trabalho familiar nos pequenos negócios, nenhuma esposa, nem os filhos disseram receber salário por seu 
trabalho. Apesar de "ajudarem" os maridos, ou assumirem o trabalho integral no trabalho fora de casa, a maioria das esposas tinha o trabalho doméstico e cuidado com filhos como suas principais ocupações. Percebeu-se que as esposas dos camelôs tinham maior nível de escolaridade em relação às dos pescadores e colhedores de laranja.

Em alguns casos, o sucesso no empreendimento possibilitava a abertura de novos pontos de venda. Alguns camelôs tinham mais de uma barraca, ou mais de um carrinho de cachorro-quente, sorvete ou trufas, entre outros produtos, em diversos locais na cidade. Em geral, familiares, como pais; filhos; primos; e irmãos, entre outros, ficavam responsáveis pelos novos pontos de venda.

O padrão de consumo estava diretamente relacionado com a renda mensal da família. Entre os trabalhadores entrevistados na pesquisa, os vendedores ambulantes eram os que mais consumiam produtos eletrodomésticos e eletrônicos lançados recentemente, como máquina de lavar; televisão; aparelho de som; telefone celular; e jogos eletrônicos, entre outros. Foi possível encontrar camelôs que tinham automóveis e motos. A maioria realizava as compras através de crediário. Quando encontravam dificuldades para obter financiamento, devido à falta de comprovante de renda, procuravam recorrer à ajuda de amigos e familiares.

Segundo relatório do ECINF $2003^{381}$, nos negócios dos trabalhadores por contaprópria ocorreu aumento de 10,7\% na quantidade de pessoas ocupadas. Considerando a existência de duas pessoas dependentes de cada trabalhador nos negócios informais, chega-se a cerca de 42 milhões de pessoas vivendo das rendas do setor informal, número que ilustra a importância desse setor na geração de renda no Brasil.

381 Pesquisa sobre economia informal urbana desenvolvida pelo Instituto Brasileiro de Geografia Estatística - IBGE com a colaboração do SEBRAE (Serviço Brasileiro de Apoio às Micro e Pequenas Empresas), 2003. 


\subsubsection{Catadores de materiais recicláveis}

À época das entrevistas, a maioria dos catadores de materiais recicláveis abordados ganhava entre um e dois salários mínimos. Apesar disso, foi encontrado um número significativo com renda de até um salário mínimo. Poucos ganhavam de dois a três mínimos com a venda dos materiais recicláveis. O tipo de material coletado e o ponto de compra - se ferro-velho ou cooperativa - determinava o rendimento. As cooperativas costumavam pagar mais pelos produtos. Por outro lado, os pagamentos eram realizados quinzenalmente. Muitos preferiam negociar com ferros-velhos para receber imediatamente. Precisavam do dinheiro para comprar alimentos, cigarros, bebidas alcoólicas e drogas ${ }^{382}$ no mesmo dia.

Poucos conseguiam poupar algum dinheiro e quando isso acontecia, costumavam guardar as economias nas casas de familiares ou pessoas conhecidas. Pretendiam comprar uma carroça maior, perua Kombi ou caminhonete para transportar materiais recicláveis em maior quantidade e comprar um barraco ou alugar uma casa. Outros pagavam pensão para os filhos, ajudavam pessoas doentes na família e saldavam dívidas com agiotas, traficantes ou colegas. Para complementar a renda, realizavam "bicos" e outras atividades, por exemplo, como vigias de igreja e de escola; faxineiros; diaristas; separadores de lixo no ferro-velho; carregadores; e transportadores de mudanças, entre outras.

Os catadores fazem parte de uma das pontas da cadeia produtiva de matériasprimas como alumínio; plástico; papel; e cobre, entre outras. Essas matérias possuem 
valor significativo em relação ao que os trabalhadores recebem pela venda ${ }^{383}$ dos materiais recicláveis para ferros-velhos e cooperativas. Enquanto alguns recebem quantias irrisórias para a sobrevivência, outros lucram muito, como as indústrias de alumínio e a indústria de sucos, por exemplo. O produto final fabricado com materiais reciclados chega ao consumidor com valor muitas vezes maior, tanto no mercado nacional, quanto no internacional.

Por trás dos catadores de materiais recicláveis e vendedores ambulantes, existem várias fábricas de equipamentos de trabalho. As carroças; carrinhos para vender cachorro-quente; barracas; e tabuleiros, entre outros equipamentos, são produzidos por pequenas empresas. Alguns catadores alugam carroças usadas nos ferros-velhos. Após pouparem uma quantia em dinheiro, decidem comprar uma nova. A carroça custa de R\$ 300,00 a 700,00, dependendo da qualidade do material utilizado, e é comprada em parcelas. $\mathrm{O}$ aumento no número de catadores e camelôs alimenta cada vez mais as indústrias de equipamentos.

Entre os catadores de materiais de reciclagem entrevistados, a maioria era moradora de rua e vivia sozinha. Alguns intercalavam um período na rua e outro em albergues, principalmente nos dias frios e quando se encontravam debilitados. Eram raros os casos de catadores com endereço fixo, em casa própria ou alugada. Os moradores de rua viviam em situação precária, sem quaisquer condições de higiene, segurança e conforto. Todos tinham sofrido algum tipo de violência (roubo e agressão física) durante a noite na rua. Alguns sofreram agressão mais de uma vez. Os catadores de materiais recicláveis utilizavam hospitais públicos, Unidades Básicas de Saúde (UBS) e a Santa Casa Misericórdia de São Paulo em situações de emergência e quando necessitavam de acompanhamento médico.

383 Valores por quilo dos principais materiais recicláveis em agosto de 2008: cobre = de $\mathrm{R} \$ 11,00$ a $\mathrm{R} \$ 14,00 ;$ metal $=\mathrm{R} \$ 6,00 ;$ alumínio $=\mathrm{R} \$ 2,80 ;$ acrílico $=\mathrm{R} \$$ 0,70 ; plástico mole $=\mathrm{R} \$ 0,40 ; \mathrm{PET}=\mathrm{R} \$ 0,30 ;$ Ferro $=\mathrm{R} \$$ entre $\mathrm{R} \$ 0,23$ a 0,$25 ; \mathrm{PVC}=\mathrm{R} \$ 0,23$; papel higiênico $=\mathrm{R} \$ 0,18 ;$ papelão $=\mathrm{R} \$ 0,15$ e vidro $=\mathrm{R} \$ 0,10$. Esses valores sofrem variação dependendo da situação financeira e econômica mundial. 
Nos albergues, os catadores encontravam melhores condições de moradia. Os sujeitos se referiam principalmente ao conforto e à higiene desses locais. Alguns relutavam em frequentar os abrigos por causa da disciplina imposta, como horários de entrada e saída; proibição da entrada de catadores alcoolizados ou drogados; cuidados com a higiene pessoal (banho, cortar cabelo, fazer barba, usar roupa limpa); e por não poderem permanecer com animais de estimação e carroças dentro das instituições, entre outras normas. Temiam que a carroça e os animais fossem roubados, mesmo estando em local apropriado.

Alguns participavam de cooperativas de catadores de materiais recicláveis, onde tinham mais informações e recebiam orientação. Haviam retornado aos estudos, conheciam seus direitos e inclusive pagavam a mensalidade da Previdência Social como autônomos. Trabalhavam na rua e dentro das cooperativas. Nestes locais, aprendiam a separar e prensar materiais, fazer o carregamento dos caminhões e preencher planilhas, entre outras atividades. Eram oferecidos cursos de artesanato com materiais recicláveis; empreendedorismo; e alfabetização de adultos. Era possível perceber uma maior solidariedade e trabalho de equipe entre esses trabalhadores. Todos tinham como meta sair da condição de morador de rua. Pretendiam alugar um barraco ou casa e arrumar outra profissão, por exemplo de jardineiro; mecânico; e dono de negócio próprio.

Os catadores que se recusavam a participar das cooperativas diziam o seguinte: "prefiro trabalhar sozinho. Tudo o que eu consigo é só meu”; e "não gosto dessa coisa de reunião e assembléia, é muita falação". A maioria dos trabalhadores era pragmática, imediatista e avessa a qualquer autoridade e trabalho coletivo. Disseram não possuir lembranças positivas de relações com chefias. Realizaram críticas, dizendo por exemplo que: “cooperativa e empresa são iguais: existe diretoria, presidente. É igual a chefe, manda na gente e dá ordens. A gente tem que contribuir todo mês. Sei lá o que fazem 
com meu dinheiro, prá onde vai”. Nunca tinham ouvido falar e não demonstravam interesse em participar dos movimentos nacionais de catadores de materiais recicláveis, ou moradores de rua. Preferiam estar sozinhos no trabalho, na vida e distantes da família. Estavam na condição de isolados, excluídos e desprotegidos na sociedade.

\subsubsection{Pescadores de lagosta}

Os pescadores de lagosta costumavam trabalhar durante sete meses por ano. Recebiam dois salários mínimos, em média ${ }^{384}$. Conseguiam receber valor maior em dinheiro no início da temporada de pesca, quando era encontrada grande quantidade de lagostas. Durante cinco meses, recebiam o seguro defeso ${ }^{385}$, referente ao período em que a pesca é proibida por causa da reprodução da espécie, no valor de um salário mínimo. Apesar de ser proibido por lei trabalhar enquanto se recebe o seguro, alguns eram obrigados a fazer "bicos" para completar a renda do benefício. Trabalhavam principalmente na construção civil, agricultura e pecuária. Alguns pescavam e plantavam para o próprio consumo.

Quando os pescadores de lagosta permaneciam em terra, era comum ocuparem o tempo bebendo, jogando, fazendo compras e consumindo o dinheiro do seguro, a ponto de ficarem endividados nos comércios e instituições de crédito locais. Acredita-se que muitos desses locais de consumo, como mercado, farmácia e lojas em geral pertencem

\footnotetext{
384 Recebiam um salário mínimo, mais a divisão dos lucros da produção. 385 Seguro defeso: Lei $\mathrm{n}^{\circ}$ 10.779, de 25 de novembro de 2003. Dispõe sobre a concessão do benefício de seguro-desemprego durante o período de defeso ao pescador profissional que exerce a atividade pesqueira de forma artesanal, individualmente ou em regime de economia familiar. Ainda que com o auxílio eventual de parceiros, fará jus ao benefício de seguro-desemprego no valor de um salário mínimo mensal, durante o período de defeso (período de interrupção legal) de atividade pesqueira para a preservação da espécie. Para o recebimento dos benefícios é necessário cumprir as seguintes exigências: comprovação da prática da pesca artesanal com inscrição no Instituto Nacional do Seguro Social (INSS) e de pagamento previdenciário por no mínimo um ano; ter registro de pescador profissional devidamente atualizado, emitido pela Secretaria Especial da Aqüicultura e Pesca da presidência da República, com antecedência mínima de um ano da data do início do defeso; ter atestado da Colônia de Pescadores a que esteja filiado, com jurisdição sobre a área onde atue o pescador artesanal.
} 
aos próprios donos de barcos, chamados de armadores. Nessa perspectiva, só restava aos pescadores aguardar o fim do período de defeso para voltarem ao mar com a esperança de uma boa pescaria e um bom dinheiro para o pagamento das dívidas. Essa dinâmica funcionava como um círculo vicioso.

Os pescadores trabalhavam em sistema de parceria com os donos dos barcos e dividiam a produção. Nesse contexto, os pescadores artesanais não possuíam um contrato de trabalho ou registro em carteira de trabalho. Os trabalhadores ofereciam a força de trabalho e os armadores, a infraestrutura (barco, equipamentos, ferramentas, alimentação entre outros itens) para a realização da pesca. Os barcos eram registrados como de pesca artesanal ${ }^{386}$ no Instituto Brasileiro do Meio Ambiente (IBAMA). Segundo o Ministério do Trabalho e Emprego, os pescadores cadastrados tinham direito de receber o seguro defeso pago pelo Estado durante os cinco meses em que vigorava a proibição da pesca.

$\mathrm{Na}$ realidade, não se tratava de pesca artesanal, e sim de pesca comercial, funcionando ilegalmente. O sistema de trabalho existente era de assalariamento sem carteira de trabalho e não de parceria. Os donos de barco ficavam com a maior parte dos lucros da pesca e os pescadores recebiam o mínimo ${ }^{387}$. A pesca não se caracterizava pela mão-de-obra familiar e nem sempre as embarcações era de pequeno porte (até doze metros). Além disso, a atividade não se destinava principalmente à subsistência de pequenas colônias de pescadores. A constatação mais grave era que cada armador costumava ter várias embarcações, registradas em nome de pessoas diferentes - na

\footnotetext{
386 A pesca artesanal é um tipo de pesca caracterizada principalmente pela mão-de-obra familiar, com embarcações de porte pequeno, como canoas ou jangadas. Sua área de atuação está nas próximidades da costa e nos rios e lagos. Os equipamentos variam de acordo com a espécie a se capturar (rede de cerco, emalhe, arrasto simples, arrasto duplo, tarrafa, linha e anzol, armadilhas e outras). Fonte: Wikipédia, consulta dia 29 de junho de 2009. 387 A proporção adotada geralmente é de $80 \%$ para o dono do barco e $20 \%$ repartido entre os pesacdores em cotas. O comandante ou mestre da embarcação pode ficar com $10 \%$ e o restante (outros 10\%) é dividido entre os demais de acordo com a função desempenhada a bordo. Segundo Ministério do Trabalho e Emprego o sistema de parceria pode ser utilizada apenas como forma de repartição do produto da pesca quando há relação de emprego regular, isto é, desde que o trabalhador tenha todos os direitos garantidos pela legislação. Neste caso os donos de barco utilizam a parceria como forma de burlar a legislação. Diversos donos de barco e armadores de pesca recebem subvenção econômica do óleo diesel. O benefício reduz em $30 \%$ o valor total do combustível, considerando o principal custo nas embarcações. As administrações estaduais e federais abrem mão de alguns impostos, barateando preço do combustível. A subvenção econômica não está condicionada ao cumprimento das normas do trabalho. (Repóter Brasil, 14/09/09 - Trabalhador da pesca lida com precariedade e má remuneração).
} 
maioria das vezes, da mesma família. E contratavam de maneira informal sete trabalhadores por barco (cinco pescadores, sendo um deles mestre de barco; um cozinheiro e um piloto).

A partilha da produção era desigual entre os pescadores, mestres e armadores. Os pescadores eram os pobres, destituídos de direitos e sujeitos "invisíveis" na cadeia produtiva da lagosta. O ganho por quilo era de $\mathrm{R} \$ 2,00$ para o pescador ${ }^{388}$ e $\mathrm{R} \$ 7,00$ para o mestre do barco. A exploração da mão-de-obra ficou evidente quando se descobriu que o armador ou dono do barco vendia o quilo da lagosta por até $\mathrm{R} \$ 90,00$ para os intermediários. Pode-se imaginar o valor deste alimento 389 "precioso" quando chega até os consumidores nacionais e internacionais. Poucos apreciadores desta iguaria podem imaginar as condições de trabalho e de vida a que os pescadores de lagosta estão submetidos.

A maioria possuía casa própria na vila de pescadores. As moradias eram modestas e tinham sido construídas com a ajuda dos próprios trabalhadores ou herdadas por familiares. As condições de infraestrutura eram precárias, sem água encanada, esgoto, asfalto e coleta de lixo regular em toda região. O tipo de habitação era familiar e numa casa, costumavam morar mais de cinco pessoas, divididas em três ou quatro cômodos. A assistência a saúde era limitada e restrita aos casos de emergência. Existia uma Unidade Básica de Saúde em funcionamento parcial, por falta de profissionais adequados. Em caso de cirurgia e acompanhamento médico, era necessário ir até a cidade mais próxima, que ficava a uma hora de carro.

388 O pescador informal recebia R\$2,00 o quilo de lagosta. Já o pescador com carteira de trabalho recebia R\$ 0,30 o quilo de lagosta. 389 Em pesquisa sobre o valor dos pratos com lagosta nos melhores restaurantes na cidade de São Paulo, descobriu-se que 350 a 400 gramas do pescado valem entre R\$ 180 e R \$ 200,00 ao consumidor. O custo elevado da lagosta está relacionado com a existência de intermediários. Além disso, segundo a informação obtida junto a gerentes de alguns estabelecimentos, as lagostas são transportadas vivas em containeres, diretamente do Ceará, por avião. Nos restaurantes, são mantidas em viveiros e recebem cuidado especial. Os clientes têm o privilégio de comer lagostas frescas, sempre acompanhadas por bebidas importadas mais caras. 
Eram poucas as esposas de pescadores que trabalhavam fora de casa. Estas costumavam fazer "bicos" como lavadeira; faxineira; empregada doméstica; bordadeira, ou mesmo confeccionando e consertando redes e armadilhas. Recebiam menos de um salário mínimo e o dinheiro era para complementar a renda obtida na pesca. A maioria das esposas realizava o trabalho doméstico e cuidava dos inúmeros filhos. Ficavam sozinhas com as crianças a maior parte do tempo durante o período da pesca, que durava sete meses. Nesse momento, tornavam-se chefes de família e tinham a responsabilidade de administrar a casa. Os maridos retornavam da pesca após um período de 30 a 40 dias. Permaneciam cinco dias em terra e depois retornavam para o mar.

\subsubsection{Colhedores de laranja}

Os colhedores de laranja recebiam, em média, pouco mais de dois salários mínimos quando não eram registrados em carteira de trabalho. Após a formalização, o rendimento era entre um salário e meio e salários mínimos. O valor em dinheiro aumentava quando além da colheita das frutas, faziam o carregamento de caminhões com laranjas. Poucos trabalhadores aceitavam, pois a atividade, pesada, era realizada logo após a jornada de colheita. Os entrevistados reclamavam que o pagamento pelo carregamento era de apenas de RS 12,00 por dia, duas horas. Alguns aceitavam a tarefa pela necessidade de aumentar a renda.

Algumas esposas de colhedores trabalhavam como empregadas domésticas; faxineiras; lavadeiras; montadoras de bijuterias; camelôs; e no enxerto de mudas. 
Recebiam menos de um salário mínimo fazendo "bicos". O dinheiro complementava a renda recebida pelos maridos na colheita.

Notou-se a presença de parentes e pessoas conhecidas residindo na casas dos trabalhadores. A maioria eram migrantes, provenientes de várias regiões no país, que trabalhavam nas colheitas de mandioca, milho, laranja e, principalmente, no corte da cana-de-açúcar. Não foi possível saber se essas pessoas contribuíam com alguma quantia em dinheiro para o pagamento das despesas da casa.

Quase não se encontravam pequenos produtores agrícolas na região estudada, a 200 quilômetros de São Paulo. As chácaras estavam deixando de lado a plantação de laranja devido ao prejuízo causado por pragas e ao alto custo do cultivo. Além disso, os produtores disseram que não compensava vender a fruta para as indústrias de suco, pois o valor recebido em troca era baixo. Assim, a maioria das terras estava arrendada para o cultivo da cana-de-açúcar - plantio extensivo bastante questionável pelos efeitos negativos que tem sobre o meio ambiente. Além disso, a introdução de tecnologias isto é, a mecanização do plantio e da colheita - acarreta o desemprego em massa de trabalhadores rurais.

As indústrias de suco tinham fazendas próprias que faziam parte da empresa, e compravam laranjas dos pequenos agricultores para aumentar a produção e atender a demanda nacional e internacional. O Brasil é um dos principais exportadores de suco de laranja no mercado mundial. O valor de mercadoria do suco de laranja cobrado do consumidor final, é muitas vezes maior que o rendimento do colhedor ${ }^{390}$. É importante ressaltar os lucros obtidos pelos fabricantes, intermediários, distribuidores e comerciantes, que encarecem o produto.

390 O colhedor com carteira de trabalho assinada recebia de R $\$ 0,35$ a R $\$ 0,45$ por 40 quilos de laranja. O colhedor sem carteira assinada recebia entre R $\$ 0,70$ e R 0,80 por 40 quilos de laranja. Já o empreiteiro ou "gato" recebia ao menos $\mathrm{R} \$ 8,00$ por 40 quilos de laranja. 
Hoje em dia, os colhedores são bóias-frias que moram nas cidades e trabalham no campo. Têm hábitos e costumes adquiridos tanto no campo, quanto no meio urbano. O mesmo fenômeno foi observado entre os pescadores de lagosta. Os colhedores costumavam consumir produtos novos, como televisão; aparelho de som; bicicleta; moto; e carro, entre outros. Alguns estavam endividados junto a instituições de crédito e financeiras e faziam "bicos" com suas esposas, trabalhando como vendedores ambulantes; montadores de bijuterias em casa para fábricas na região; vendedores de lingerie; e catadores de materiais recicláveis.

A maioria dos colhedores tinha casa própria em um bairro da periferia de Limeira, conhecido por abrigar esse tipo de trabalhador. terreno e construíram sua casa durante anos, conforme a disponibilidade financeira. Alguns trabalhadores pagavam aluguel pela moradia e reclamavam que esse gasto aumentava a cada dia, ao contrário dos salários. O maior sonho destes inquilinos era ter casa própria.

Em geral, as condições de moradia, como a infraestrutura, eram boas nas casas dos colhedores. O tipo de habitação era familiar, onde viviam mais de cinco pessoas, distribuídas entre quatro ou cinco cômodos, ou mais. Existia uma Unidade Básica de Saúde no bairro, que procurava atender os moradores através dos vários programas existentes, por exemplo o Programa de Saúde da Família, citado por vários entrevistados da pesquisa.

Quando os colhedores de laranja reclamavam do salário, do custo da alimentação, das condições de moradia e das condições de trabalho, consideravam o governo, ou os políticos culpados. Em nenhum momento, imaginavam que a sua iniciativa, participação, ou organização política enquanto trabalhadores pudesse transformar a realidade social. Já tinham ouvido falar da atuação das organizações sindicais rurais e não demonstraram interesse em conhecê-las melhor. 
$\mathrm{Na}$ época da pesquisa, estava em curso a campanha eleitoral para vereadores e prefeito. Ao comentar o fato, alguns colhedores diziam que "político é tudo igual, nenhum presta"; e que "fazem promessas e depois não cumprem". Outros acreditavam na política e faziam campanha para candidatos, principalmente os que se preocupavam em atender as necessidades dos moradores do bairro em que a maioria morava.

Apesar de demonstrarem desconfiança em relação aos políticos em geral, os entrevistados elogiavam o Programa Bolsa Família e as ações do presidente da República. Havia identificação com Lula, porque foi "trabalhador" e "peão", mas conseguiu vencer na vida. Os colhedores diziam que as condições econômicas tinham melhorado no governo Lula, apesar de ainda não estar em nível satisfatório.

Conforme os entrevistados ressaltaram, as melhoras da situação financeira nos últimos anos estão refletidas no aumento no valor do salário mínimo e num desenvolvimento econômico em expansão. Seu poder de compra havia aumentado, permitindo a aquisição de diversos produtos e a construção de suas casas. Porém, os colhedores também criticaram as políticas públicas de assistência à saúde, devido à falta de hospitais e prontos-atendimentos na região de moradia; à falta de profissionais, especialistas, medicamentos e ambulâncias; e à demora para agendar consultas médicas. Outro fator de descontentamento era a infraestrutura do bairro, com rede de esgoto, água encanada e iluminação deficitárias, péssimas condições das vias públicas e, principalmente, falta de segurança, com o aumento da violência.

A maioria dos entrevistados destacou a dificuldade de acesso dos filhos às escolas, apesar de muitas regiões já disporem de transporte público para levar os alunos. A qualidade do ensino, a dificuldade de aprendizagem e as repetências também estavam entre as preocupações dos trabalhadores. Um dado importante de meu estudo é que 
todos os filhos em idade escolar de colhedores estavam frequentando escolas, sendo que muitos tinham um nível de escolaridade maior que o de seus pais.

Nesse caso, podemos associar a ida à escola pelas crianças às vantagens de receber os benefícios concedidos pelo governo. Outra razão para o comparecimento das crianças à escola seria o desejo dos trabalhadores de que os seus filhos tivessem um futuro melhor. Todos os pais foram unânimes ao considerar os estudos como um meio de conseguir uma profissão com melhor status e salário. A mudança social deveria ocorrer através dos estudos e trabalho. A ascensão social dos descendentes era uma forma de melhorar as condições de vida de toda família. 


\section{CAPÍTULO 5: AS CONDIÇÕES DE SAÚdE E SEGURANÇA NO TRABALHO INFORMAL}

Há uma parte significativa da população trabalhadora brasileira sobre a qual é difícil dizer se a saúde, a esperança de vida e a expectativa no trabalho estão melhorando ou não. $\mathrm{O}$ pouco que se sabe sobre essa população vem de estudos epidemiológicos e de $\operatorname{casos}^{391}$. Esses estudos mostram que existem focos localizados de altíssimas taxas de mortalidade devido a acidentes relacionados ao trabalho e doenças profissionais. Apesar da existência de alguns de estudos de casos, não temos conhecimento de nenhum estudo geral sobre essa população. Este fato pode ser uma demonstração da exclusão social, da injustiça e da falta de equidade existentes no país.

No Brasil, como nos países em desenvolvimento de maneira geral, uma boa parte da população ocupada está inserida no trabalho do tipo tradicional e no trabalho informal e não-regulamentado. Nesta situação, encontramos relações de trabalho autoritárias, prevalecendo a precarização no trabalho, a falta de segurança, a assistência médica de péssima qualidade, a pobreza, a fome e a exploração. Tanto o trabalho do tipo tradicional, quanto os trabalhos informais e não-regulamentados podem ser considerados parte de uma zona de exclusão em relação à área de saúde e segurança no trabalho. Se isto forma um quadro perturbador para alguns, é considerado por outros como algo natural, que faz parte da realidade brasileira - contexto de difícil resolução e, sendo assim, de pouca importância política e de pouca relevância para a ciência.

\footnotetext{
391 JOSÉ-SILVA, M. de F. (2006). Para onde vamos? A saúde física e mental de ex-empregados do mercado de trabalho formal, do ramo de metalurgia, que se encontram empregados/ocupados na informalidade. Um estudo comparativo entre Brasil e Argentina. Tese de Doutorado, Programa de Pós-Graduação em Integração da América Latina - PROLAM, Universidade de São Paulo; DALL'OCA; A . W. (2003). Diagnose da Entidades Envolvidas com a Pesca Profissional no Estado do Mato Grosso do Sul. Revista Brasileira de Saúde Ocupacional, São Paulo, 27(103/104), 103-116; REIS JUNIOR, F. A. (2005). Pesca da lagosta com o uso de compressor: os riscos do trabalho em condições hiperbáricas. Paper apresentado no 27th International Congress on Occupational Health (ICOH) - Foz de Iguaçu, Brasil, 2003; IBANHES, L. C. (1999). O Setor Informal Urbano: a Organização e as Condições de Saúde de um Grupo de Vendedores Ambulantes. Tese de Doutorado, Programa de Pós-Graduação em Saúde Pública, Departamento de Prática de Saúde Pública, Faculdade de Saúde Pública da Universidade de São Paulo.
} 
É importante perceber que muitas das variáveis que estão sendo usadas para explicar as quedas das taxas de acidentes do setor formal no país, como a atuação do movimento sindical, a fiscalização do Ministério do Trabalho e Emprego, a ação dos técnicos, entre outras, não exercem nenhum efeito sobre os trabalhadores do setor informal. Sendo assim, sabemos pouco sobre o que acontece com os trabalhadores na informalidade. Apesar disso, vale lembrar que o próprio Ministério do Trabalho e Emprego tem tomado iniciativas de combate ao trabalho precário e não-regulamentado há alguns anos. Através de ações de fiscalização e orientação, procura-se diminuir as taxas de trabalho escravo, infantil, degradante e precário, entre outros, tanto nas área rural, quanto na urbana.

No Brasil, o Departamento de Segurança e Saúde no Trabalho (DSST) da Secretaria de Inspeção do Trabalho do Ministério do Trabalho e Emprego; o Ministério da Saúde; e o Ministério da Previdência e Assistência Social reconhecem a precariedade dos dados referentes ao setor informal e a necessidade de se investigar a situação real do país - o que se tem traduzido num esforço conjunto de algumas universidades, instituições de pesquisa e órgãos de informação na busca de dados sobre acidentes e doenças profissionais com trabalhadores que atuam no setor informal.

As principais fontes de informação encontradas nos estudos dos acidentes e das doenças do trabalho, que procuram abranger o setor informal são: o Sistema de Informação de Mortalidade do Ministério da Saúde (SIM/MS) - Declaração de Óbito (DO); e o Sistema de Informação Hospitalar do SUS (SIH/SUS). Além dos sistemas de informação citados acima, as pesquisas domiciliares, seguindo o rigor metodológico, contribuem para ampliar a cobertura e a produção de conhecimento sobre as condições de saúde e segurança no setor informal do mercado de trabalho ${ }^{392}$.

392 MATSUO, M. Death from external causes - Recent evolution and the need for change of focus. OSH \& Development, $\mathrm{n}^{\circ}$ 8, Swedish Association for Occupational and Environmental health \& Development (UFA) December, 2006. 
Foi constatado que características peculiares do "setor" informal da economia dificultam o estudo sistemático das condições de trabalho e da saúde e segurança do trabalhador. Parte das atividades do "setor" informal ocorre em ambientes caracterizados por ausência de limites físicos ou territoriais; e grande amplitude, desorganização ou mobilidade dos espaços de trabalho, como por exemplo, no caso das pessoas que trabalham nas ruas ${ }^{393}$.

Além do trabalho nas ruas, há atividades que ocorrem em ambientes bem delimitados, muitas vezes no ambiente domiciliar, frequentemente com instalações improvisadas e sem utilização de dispositivos de proteção ambiental coletiva e/ou proteção individual do trabalhador. Apesar de delimitado, o ambiente de trabalho, na maioria das vezes, não recebe vistoria dos órgãos de fiscalização do trabalho, à medida que os empreendimentos domésticos não podem ser identificados como empresas regulares, com cadastro jurídico ${ }^{394}$.

De forma geral, as condições de trabalho no setor informal, nas pequenas e microempresas, nos domicílios e nas ruas são perigosas e insalubres, observando-se nesses contextos a presença de múltiplos fatores de risco para a saúde e a ausência de dispositivos e mecanismos básicos de proteção. Somam-se a esses fatores de risco presentes ou decorrentes do trabalho a ausência de proteção legal assegurada pela informalização do contrato de trabalho; o descumprimento de normas básicas de segurança; a ausência de fiscalização; além da falta de cobertura do seguro social e por acidentes do trabalho ${ }^{395}$.

Nas atividades realizadas em ambientes domiciliares e pequenas e microempresas, a falta de manutenção preventiva dos equipamentos e maquinários; a

393 MENDES, R. \& CAMPOS, A. C. C. (2004). Saúde e Segurança no Trabalho Informal: Desafios e Oportunidades para a Indústria Brasileira. Rev. Bras. Med. Trab.; Belo Horizonte, vol.2, nº 3, jul - set. p. 209-223, p. 215. 394 MENDES, R. e CAMPOS, A. C. C. (2004). p. 215.

395 DIAS, E. C. (2002). Setor informal de trabalho: um novo-velho desafio para a saúde do trabalhador. In: SALIM C. A.; CARVALHO, L. F. (organizadores). Saúde e segurança no ambiente de trabalho: contextos e vertentes. Belo Horizonte: FUNDACENTRO, Universidade Federal de São João Del Rei, p. 151-68. 
ausência de equipamentos de proteção, tanto ambientais quantos individuais; e a insuficiência de treinamento dos trabalhadores se somam aos fatores de risco à saúde específicos das atividades desenvolvidas nesses locais. No trabalho informal realizado em ambientes domiciliares, há o agravamento da situação devido ao fenômeno denominado "domiciliação do risco", onde não somente os trabalhadores, mas também suas famílias estão expostas aos mesmos riscos ocupacionais da atividade desenvolvida ${ }^{396}$.

Apesar de não estarem disponíveis informações confiáveis, é possível inferir a ocorrência de altos índices de acidentes do trabalho e doenças profissionais e relacionadas ao trabalho que se superpõem às causas de adoecimento próprias das más condições gerais de vida e da precariedade dos serviços sociais prestados a essa população - entre eles, o de saúde.

A questão do trabalho precário tem chamado atenção nos países desenvolvidos nas últimas décadas. A reestruturação produtiva e a crise financeira mundial têm provocado o aumento de desemprego e, consequentemente, a flexibilização das relações de trabalho. A bibliografia internacional sobre saúde e segurança no trabalho mostra que os trabalhadores terceirizados ou temporários ocupam atividades mais perigosas do que os demais - como as operações de manutenção de processos industriais -, e as realizam sem as medidas de proteção requeridas para os demais trabalhadores (efetivos) ${ }^{397}$. Essa mesma bibliografia mostra que no setor informal, pequenas empresas de atividade irregular costumam envolver processos operacionais rudimentares, nos quais os

396 NAVARRO, V. L. (1998). A produção de calçados de couro em Franca (SP): a reestruturação produtiva e seus impactos sobre o trabalho. Tese de Doutorado. Araraquara: Faculdade de Ciências e Letras da UNESP; Idem (2003). O trabalho e a saúde do trabalhador na indústria de calçados. São Paulo em Perspectiva, 17 (2): $32-41$.

397 QUINLAN, M.; MAYHEW, C.; e BOHLE P. (2001). The global expansion of precarious employment, work disorganization, and consequences for occupational health: a review of recent research. International Journal of Health Services, 31:335-413. 
procedimentos de segurança são precários ou inexistentes - o que pode explicar a alta taxa de acidentes do trabalho verificada entre esses trabalhadores ${ }^{398}$.

Este capítulo divide-se nos seguintes itens: no item 6.1., são analisadas as condições e organização de trabalho dos pescadores de lagosta, catadores de materiais recicláveis, vendedores ambulantes e colhedores de laranja; no item 6.2., discutem-se os acidentes de trabalho típicos e as ocorrências de violência contra os trabalhadores, que se manifestam nas formas de agressões físicas e verbais, tentativas de homicídio e roubo, entre outras; no tópico 6.3., são apresentadas as doenças profissionais referidas pelos sujeitos, passando pela saúde física e mental - esta avaliada a partir do discurso sobre sofrimento psíquico no desempenho da atividade e do prazer como mecanismo de defesa; e no item 6.4. são relatadas as expectativas dos indivíduos em relação ao futuro.

\subsection{Condições de trabalho}

A precariedade se constata principalmente em relação às condições físicas e ergonômicas; à intensificação do trabalho; às jornadas prolongadas; ao ritmo intenso; e às poucas pausas para repouso, entre outros aspectos. A ausência de condições de higiene e conforto é percebida em todas as ocupações. A exigência de força física se faz notar, independentemente da idade e do sexo. A relação de trabalho costuma ser tensa e conflituosa. Entre os pescadores de lagosta e colhedores de laranja, destaca-se a presença dos armadores (donos de barcos), mestres de barco, "gatos" e empreiteiros,

398 LOWENSON, R. Health Impact of Occupational Risks in the Informal Sector in Zimbabwe (1998). International Journal Environment and Occupational Health, 4 (4): $264-274$. 
que cumprem o papel de chefes e patrões. Os trabalhadores informais que atuam em ambiente aberto são afetados principalmente pelo sol forte, altas temperaturas e chuvas.

Riscos - os pescadores de lagosta e colhedores de laranja precisam cobrir o corpo todo para se proteger do sol. Usam chapéu; boné; protetor de pescoço e orelhas (chamado de "mangote"); camisa de manga longa; calça comprida; tênis ou bota; e outros acessórios. Os colhedores de laranja usam luvas por causa dos espinhos e perneiras de couro para não machucar a perna nas escadas. Não usam óculos devido ao incômodo causado pelo suor no rosto e pelo vapor, que embaça as lentes. Já os catadores de materiais recicláveis não utilizam luvas, pois estas incomodavam no manuseio dos objetos coletados.

Dentre os trabalhadores pesquisados, os catadores são os que tomam menos precauções em relação à segurança no trabalho. A maioria usa boné, camiseta de manga curta, calça comprida ou bermuda e poucos possuem calçados adequados. Percebe-se que os catadores de cooperativas têm mais conhecimentos sobre segurança no trabalho. Costumam trabalhar com equipamentos de proteção, inclusive protetor solar.

O sol forte é prejudicial para a conservação dos alimentos manuais e industriais vendidos pelos vendedores ambulantes. Esses trabalhadores têm a possibilidade de usar guarda-sol, ficar debaixo das marquises ou não trabalhar nos dias mais chuvosos.

A chuva dificulta a atividade de todos os trabalhadores. As carroças dos catadores ficam mais pesadas com os materiais molhados nos dias de chuva. Os colhedores de laranja não podem trabalhar devido ao risco de caírem das escadas e recebem apenas $\mathrm{R} \$ 13,00$ por dia parado. Os camelôs reclamam porque os fregueses desaparecem e a venda diminui. Os pescadores de lagosta trabalham sob chuva, mas 
temem as tempestades, ventos fortes e ondas gigantes que podem virar o barco ou quebrar a proa.

Ruído, poluição, vento, excesso de veículos, pouco espaço nas ruas e calçadas, trânsito e congestionamento intenso são queixas comuns dos catadores de materiais recicláveis e vendedores ambulantes. $\mathrm{O}$ trabalho ao ar livre e próximo à natureza, o ar puro, o silêncio e o fato de não ficarem em meio a concentrações de pessoas são as características que mais satisfazem os pescadores de lagosta e colhedores de laranja em seu trabalho. A única reclamação dos colhedores foi quanto ao cheiro dos agrotóxicos, utilizados eventualmente. Alguns pescadores e colhedores declararam que não há dinheiro no mundo que valha a "liberdade" que sentem no trabalho. Gostam do mar e terra e dificilmente se imaginam trabalhando em ambiente fechado por muito tempo. A identificação com a vida próxima à natureza apareceu durante a pesquisa quando os pescadores disseram ser "bicho do mato" e "peixe fora d'água", referindo-se aos períodos fora do mar.

Condições de higiene - A falta de equipamentos de higiene, como banheiro e chuveiro, foi uma reclamação da maioria dos trabalhadores. Os colhedores de laranja têm o banheiro químico, apelidado de "tenda" ou "cabana", para satisfazer as necessidades fisiológicas. Esse equipamento foi instalado há pouco tempo por imposição da fiscalização do trabalho rural. Os entrevistados disseram sentir constrangimento em ir ao banheiro, pois viravam motivo de chacota e gozação de colegas. A maioria preferia manter o costume e hábito adquirido na infância: usar o mato durante as pausas no trabalho. Alguns não aceitavam ir à "tenda", nem usar o mato; satisfaziam suas necessidades apenas quando voltavam para casa. Diziam estar acostumados e que não sentiam qualquer problema, apesar de beberem muita água devido ao calor. 
Os pescadores de lagosta viviam em situação precária. Percebe-se a falta de equipamento de higiene como banheiro (os pescadores faziam suas necessidades fisiológicas acocorados na borda do barco, sem qualquer privacidade) e chuveiro (tomavam banho de mangueira ou na bacia com água do mar e tinham direito a uma ou duas latas de óleo com água doce por dia para enxaguar e tirar o sal do corpo). As roupas eram lavadas com água do mar ou da chuva. Havia preocupação em manter o racionamento da água doce para beber e para o banho.

Os catadores de materiais recicláveis procuravam realizar sua higiene pessoal como o banho, por exemplo - em média de duas a três vezes por semana. Nas igrejas, conseguiam fazê-lo de modo gratuito; e nos postos de gasolina, pagando uma taxa mínima de $\mathrm{R} \$ 5,00$. Lavavam suas roupas uma vez por semana, quando possível. Os moradores de albergue tinham condição de se lavar e usar a lavanderia todos os dias. Em geral, os catadores possuíam poucas peças de roupas, pois costumavam ser roubados enquanto dormiam na rua.

Durante a atividade de trabalho, encontravam dificuldade para satisfazer suas necessidades fisiológicas. Alguns disseram usar banheiros de restaurantes populares (como os da rede Bom Prato, por exemplo) e bares. Dependendo da situação, eram obrigados a utilizar as ruas, escondidos em locais com menos transeuntes, e até mesmo em cima dos materiais recicláveis empilhados sobre a carroça.

No caso da higiene pessoal, as mulheres carroceiras foram as que mais reclamaram da dificuldade para fazer suas necessidades fisiológicas e, principalmente, trocar absorventes íntimos. Os trabalhadores se sentiam humilhados e discriminados com a situação, pois em muitos bares, padarias e restaurantes eram impedidos de entrar para consumir e usar os banheiros, pois estavam mal vestidos e com péssimo odor. 
Os vendedores ambulantes foram os que menos reclamaram da falta de banheiros. Quando sentiam a necessidade, recorriam aos bares e comércios próximos a seus pontos de venda. Para não ficarem constrangidos, procuravam consumir algum produto de vez em quando. Disseram que a relação com os lojistas era tranquila e amigável. Procuravam deixar a calçada limpa, ocupar pouco espaço com as mercadorias e não atrapalhar a entrada e saída de clientes dos comércios. Alguns trabalhadores estavam acostumados a satisfazer as necessidades fisiológicas apenas em suas casas. Reclamaram dos banheiros sujos e da falta de papel higiênico.

Espaço de trabalho - $\mathrm{O}$ problema do espaço de trabalho restrito foi referido por pescadores de lagosta e camelôs. Os pescadores precisavam permanecer confinados durante longo período no barco. As embarcações possuíam chão irregular e cheio de obstáculos, com vários objetos espalhados, como caixas de redes e poita, entre outros. Era preocupante o fato da maioria das embarcações não ter equipamentos básicos de segurança e salvatagem. A cozinha ficava no espaço da cabine, que tinha dois beliches de três andares. Os trabalhadores dormiam sobre espumas sujas e envelhecidas. Tinham que levar poucos pertences, apenas as roupas do corpo, de cama e produtos de higiene pessoal.

Com o número crescente de camelôs, diminuiu o espaço para equipamentos como tabuleiros; bancas fixas e desmontáveis; plásticos no chão; e carrinho manual, entre outros. Para evitar brigas e discussões sobre o local do ponto de venda, era feito um acordo verbal entre os vendedores regulares (com Termo de Permissão de Uso), irregulares e lojistas. Alguns vendedores ambulantes reclamaram que não havia lugar para colocar uma cadeira ou banco. Permaneciam em pé quase o dia todo e descansavam na hora do almoço nos bares e restaurantes. 
Em relação ao espaço físico restrito, o caso mais preocupante é o dos vendedores ambulantes de colchas e redes da Paraíba, que viajam dentro de um caminhão-baú com péssima ventilação pelo Brasil e outros países da América Latina. O grupo entrevistado tinha de 30 a 40 trabalhadores, que permaneciam o tempo todo sentados ou deitados sobre as mercadorias. Quando paravam nos postos de gasolina das estradas, aproveitavam para tirar um cochilo em redes; tomar banho; e lavar roupa. Ficavam em algumas cidades por alguns dias ou semanas, montavam seus pontos de venda e faziam as refeições e usavam os banheiros de bares e restaurantes próximos. Seu maior medo era o de serem pegos pela Polícia Rodoviária. Se isso acontecesse, os trabalhadores estavam orientados a dizer que não tinham nada a ver com a distribuidora. Estavam pegando carona para ir à cidade mais próxima, à procura de trabalho.

Esforço físico - Os pescadores foram unânimes em relação ao uso intenso de força física. As tarefas de transportar carga, tirar "manzuás" ou "covos" "399 do mar, pegar a caixa do gelo do chão, carregar o pescado, pegar o tambor de água e carregar o galão de óleo nem sempre eram executadas de maneira adequada. Atualmente existem as estruturas conhecidas como "pau de carga", guinchos manuais ou roldanas ${ }^{400}$, criadas e adaptadas pelos próprios pescadores com a finalidade de auxiliar no transporte de pesos. Tais equipamentos aumentam a segurança do trabalho e aliviam a necessidade de uso da força pelo pescador. Apesar disso, a pesquisa observou que a maior parte dos equipamentos continuam sendo transportados para os barcos de maneira tradicional, isto é, utilizando apenas a força física dos trabalhadores.

Durante a preparação do barco para o início da pesca, foi possível observar vários pescadores carregando blocos enormes e pesados de gelo apoiados nas costas.

399 Armadilhas para pescar lagostas.

400 Secretaria Especial de Aquicultura e Pesca - SEAP (2007). Saúde e Segurança do Pescador. Série Formação e Valorização do Pescador. 
Estes blocos eram retirados de um caminhão das indústrias de gelo que fícavam à margem do rio - muitas pertencentes aos próprios armadores - e carregados até o barco, em muitos casos distante. Percebeu-se que nem sempre era possível que os caminhões parassem perto das embarcações e que o caminho de deslocamento era irregular, com a existência de escadas, um barranco e outros obstáculos, como os vários barcos atracados um ao lado do outro. A operação era feita em conjunto, por vários trabalhadores que carregavam o bloco de gelo, passado de mão em mão até o local de armazenagem no porão de uma das embarcações.

Os catadores precisavam pegar os materiais, muitas vezes pesados, levantá-los e colocá-los sobre a carroça. Costumavam caminhar até 40 quilômetros por dia, puxando um peso de no mínimo 300 quilos, até 800 quilos, sendo que alguns puxavam carroças pesando uma tonelada. Já os colhedores de laranja ficavam agachados, em pé e em cima de escadas carregando uma sacola cheia de laranjas. Além disso, tinham que andar de 30 a 50 metros até a bancada onde as sacolas eram depositadas para ser recolhidas no final do dia. Colhiam de 20 a 25 quilos na parte superior da árvore e depois completavam a sacola até os 37 ou 40 quilos na parte inferior. Alguns colhedores faziam o carregamento dos caminhões, levantando ou puxando as sacolas de laranja ininterruptamente durante quase duas horas.

No dia-a-dia, os camelôs precisam carregar mantimentos, mercadorias, pegar várias conduções e dirigir pelas ruas congestionadas da cidade. Todos os entrevistados reclamaram do esforço físico necessário, sendo que alguns preferiam deixar os equipamentos e mercadorias em estabelecimentos ou domicílios próximos aos pontos de venda. Para isso, recebiam ajuda de pessoas conhecidas ou pagavam uma quantia em dinheiro por mês. Em certos casos, os vendedores tinham que buscar suas barracas 
fixas, que ficavam guardadas em local determinado pela prefeitura. Ao final da jornada de trabalho, levavam as barracas de volta, mas reclamavam do peso e da distância.

Outros montavam e desmontavam a barraca ou tabuleiro no dia. A maioria realizava a tarefa sozinha. Eram raros os que contavam com ajuda de colegas ou de algum familiar nesse momento. Dependendo do caso, era necessário limpar os equipamentos, as caixas de alumínio, o freezer e a geladeira, entre outros, ao chegar em casa, o que exigia muito esforço físico. Além disso, os vendedores de alimentos manuais ou frutas precisavam comprar a mercadoria no dia ou, no máximo, na véspera. As maiorias das vezes precisavam carregar as compras e andar de ônibus.

Alimentação - A comida foi considerada razoável pelos pescadores. Disseram que a qualidade da alimentação dependia do cozinheiro da embarcação e da conservação dos alimentos. Havia o perigo dos trabalhadores passarem mal, dependendo da comida estar ou não estragada. Costumavam se alimentar, no almoço e jantar, principalmente de arroz, feijão, farinha, carne, frango e peixe. O café da manhã consistia em café e pão com margarina. Como acordavam muito cedo, tomavam um mingau no meio da manhã. Em relação à alimentação, os pescadores reclamaram que a água acondicionada por muito tempo dentro dos tonéis de plástico (PVC) ficava salobra. Desse modo, alguns trabalhadores preferiam levar sua própria água. No passado, a situação fora pior, contaram, pois os tonéis eram de metal e a ferrugem se misturava à água - o que causava problemas de saúde aos pescadores.

Entre os catadores de materiais recicláveis, alguns se alimentavam nas igrejas, restaurantes populares, albergues e bares. Quando gastavam com o café da manhã, esse valor era em média $\mathrm{R} \$ 2,50$. O almoço ficava entre $\mathrm{R} \$ 1,00$ e $\mathrm{R} \$ 5,00$ (o primeiro no restaurante popular e o segundo em bares, o conhecido "prato feito"). A maioria dizia 
não jantar. Os catadores entrevistados contaram que ganhavam muitos alimentos na rua durante o dia. Procuravam guardar a comida, para requentar no fogareiro a álcool e comer antes de dormir. Um catador chegou a comentar com a pesquisadora, em tom de brincadeira, que:

As pessoas não podem ver um carroceiro que logo querem dar comida. Dão prato de comida inteiro, lanche, frutas... A gente não recusa. Isso é falta de educação. Eu pego tudo, agradeço e guardo pra comer depois à noite. Aproveito e divido com os amigos da rua. No calor, a comida chega a estragar de tanto que é. Parece que catador tem cara de 'morto de fome', pois as pessoas logo querem dar alguma coisa para comer.

Os camelôs tomavam o café da manhã em casa e costumavam almoçar em bares ou restaurantes por quilo. Os vendedores de cachorro-quente, minipizza e salgados preferiam se alimentar de seus produtos. Alguns trabalhadores traziam lanche ou marmita de casa. Essa iniciativa ajudava a economizar dinheiro. Reclamavam que a comida era fria e que costumava estragar no calor. Os casos em que alimentos frescos e quentes eram levados por pessoas da família eram raros.

Esses trabalhadores não possuíam qualquer conforto ou privacidade. Eram chamados várias vezes pelos clientes durante as refeições. Os camelôs que faziam as refeições em bares, lanchonetes ou restaurantes por quilo demoravam pouco tempo para comer. Entrevistados disseram que gostariam de comer no restaurante popular Bom Prato, pagando R\$ 1,00, mas não o faziam para evitar as longas filas. Precisavam retornar rapidamente às barracas que tinham deixado sob os cuidados de algum colega. Alguns vendedores passavam o dia sem comer e bebiam pouco líquido. Preferiam se 
alimentar em sua própria casa depois da jornada de trabalho. Disseram que estavam acostumados e não sentiam fome.

Os colhedores de laranja faziam uma pausa de dez minutos após uma ou duas horas de trabalho. Bebiam água e fumavam cigarro. Os mais jovens não paravam, para não atrapalhar a produção. Os trabalhadores descansavam principalmente quando havia sol forte e temperatura alta. Tomavam café da manhã às $5 \mathrm{~h}$ e preferiam almoçar entre as 8 e as 9 horas. Disseram que sentiam fome nesse horário e que a comida ainda estava quente na marmita térmica - equipamento que começou a ser fornecido de maneira obrigatória pelos "gatos" ou "turmeiros" após intervenção da fiscalização do trabalho na área rural do Estado de São Paulo. Antes, os trabalhadores usavam recipientes de plástico ou marmita de alumínio e o alimento estragava com o calor, pois não havia refrigerador no local de trabalho. Os entrevistados disseram que a situação melhorou, mas que o problema não estava totalmente solucionado. Comiam muito arroz e um pequeno pedaço de linguiça, frango, carne e ovo mexido ou cozido. Alguns não levavam feijão, pois costumava estragar no dias quentes. Os trabalhadores relataram que às vezes não almoçavam, pois não tinham apetite. Alguns comentaram que se alimentavam pouco no jantar.

Os "gatos" ou "turmeiros", entre $13 \mathrm{~h}$ e $14 \mathrm{~h}$, forneciam lanche: um copo de café com leite e pão francês com manteiga ou margarina. Cada trabalhador controlava o tempo de refeição, para voltar o quanto antes ao trabalho e produzir o máximo possível. O local para pausa era inadequado e sem conforto. Alguns almoçavam rapidamente e depois cochilavam 20 minutos. Almoço, lanche e descanso eram feitos debaixo dos pés de laranja, próximo ao agrotóxico e aos insetos. 
Jornada de trabalho - a jornada de trabalho do vendedor ambulante dependia da quantidade de clientes. Em períodos próximos às datas comemorativas, o movimento costumava ser intenso. A maioria trabalhava por mais de dez horas por dia, nos sete dias da semana. Essa jornada durava de um a dois meses, principalmente na época do Natal e do Dia das Mães. Em outros momentos, de baixa temporada, os camelôs trabalhavam até nove horas por dia, em cinco ou seis dias da semana. Percebeu-se um número expressivo de camelôs que trabalhavam nos sete dias da semana durante todos os períodos no ano. A maioria dos vendedores não tinha condução própria. Precisavam tomar várias conduções para chegar até o local de venda. O tempo de deslocamento era de 2 a 3 horas por dia, em média.

Os vendedores disseram que a jornada de trabalho diminuiu consideravelmente nos últimos anos devido ao aumento da concorrência. Vale destacar que as mulheres costumavam trabalhar mais tempo devido à dupla jornada, conforme discutimos no subitem sobre a condição das mulheres. Alguns aproveitavam o tempo livre fazendo "bicos" para complementar a renda mensal. Outros faziam cursos de curta duração, como computação; artesanato; culinária; e língua estrangeira, entre outros, ou retornavam ao ensino regular a fim de concluir os estudos. Prevalecia o tipo de trabalho familiar em que esposa, marido, filhos e demais parentes ajudavam nos horários de maior movimento. Os casos em que camelôs contratavam outros assalariados sem carteira de trabalho foram raros.

Os catadores eram verdadeiros andarilhos. Caminhavam até 40 quilômetros por dia, procurando materiais recicláveis nas ruas ou buscando diretamente nas lojas e empresas. A jornada de trabalho era de 14 a 16 horas por dia. Faziam pequenas pausas para descanso e refeições durante a jornada. A maioria trabalhava a semana inteira. Poucos descansavam aos sábados ou domingos. Preferiam andar sozinhos. Existia 
competição acirrada pelo lixo. Os entrevistados comentaram que o aumento do número de catadores e a coleta feita pelos caminhões da prefeitura e as cooperativas faziam diminuir os materiais recicláveis nas ruas. Eram obrigados a trabalhar cada vez mais para encontrar algo.

O ritmo de trabalho era intenso e os catadores focavam atenção nas lixeiras, sacos de lixo, entulhos e caçambas enquanto caminhavam pelas ruas. Tinham tempo determinado para realizar a coleta; buscar materiais recicláveis reservados nos condomínios, comércios e escritórios; e vender nos ferros-velhos ou cooperativas. Costumavam consumir drogas, como maconha e "crack", para obter força física e estímulo, a fim de produzir o máximo possível durante a jornada. Além disso, ingeriam bebidas alcoólicas para suportar o cheiro do lixo em decomposição.

Alguns disseram que à noite costumavam beber pinga ou cachaça para enfrentar o frio, o medo da violência e conseguir dormir de 5 a 6 horas. Nos albergues, havia horário de entrada e saída, para acordar e dormir. As regras tinham que ser seguidas rigorosamente, sob pena de expulsão. Em algumas instituições, era oferecida uma refeição à noite e café da manhã. A maioria dos carroceiros reclamava que o horário de entrada era limitado. Precisavam coletar os materiais recicláveis até tarde da noite. Outros preferiam dormir sozinhos, ou junto a outros moradores de rua, pois prezavam a liberdade para beber e consumir drogas. A carroça era o instrumento de trabalho que poderia ser roubada se eles não permanecessem próximos. Os animais de estimação, principalmente cachorros, eram muitas vezes o único vínculo afetivo dos catadores.

Os pescadores de lagosta tinham jornada de trabalho de no mínimo 17 horas (das $1 \mathrm{~h}$ às $18 \mathrm{~h}$ ) por dia se a pesca da lagosta era realizada com rede. Com os "manzuás" ou “covos", esse tempo diminuía para 12 horas (das 4 h às 16 horas). No início da temporada de pesca, quando há maior número de lagostas, a jornada aumentava 
significativamente. Os pescadores trabalhavam 17 horas ou mais e dormiam em média quatro horas por noite.

A rotina de trabalho consistia na atividade da pesca e arrumação dos apetrechos e equipamentos no convés do barco; conserto dos "manzuás"; limpeza da roupa e outras atividades. As pausas eram quase inexistentes, pois ao mesmo tempo em que os trabalhadores pescavam, realizavam as refeições, por exemplo. Permaneciam na região costeira de 30 a 40 dias. Depois disso, retornavam e descansavam cinco dias em terra, para partir novamente ao mar. Além da jornada diária prolongada, os pescadores trabalhavam durante os sete dias da semana.

As longas horas de trabalho sob sol forte, vento e chuva ou tempestade, o esforço físico e o sofrimento psíquico faziam com que após a jornada, os pescadores procurassem repousar, dormindo o máximo possível. Algumas vezes, jogavam cartas com os colegas. Não existiam pausas durante a execução das tarefas, pois sempre estavam fazendo alguma coisa, como por exemplo arrumar os apetrechos e equipamentos de pesca no barco.

Os colhedores de laranja tinham jornada de trabalho de mais de doze horas, isto é, produziam enquanto houvesse luz do dia. Após obter o registro em carteira de trabalho, a maioria tinha passado a trabalhar nove horas por dia. Alguns estendiam a jornada para dez a onze horas quando aceitavam fazer o carregamento do caminhão com laranjas. Levavam cerca de duas horas para realizar a tarefa ${ }^{401}$. No início da colheita, chegavam a trabalhar até sete dias por semana. Com a fiscalização e registro em carteira de trabalho, passaram a trabalhar de segunda a sábado, até as 12 horas. Além disso, gastavam em média uma hora de ônibus para ir até a plantação de laranja e uma hora para voltar até o bairro em que moravam.

401 Um colhedor levantava a sacola de laranja, pesando 40 quilos, acima de sua cabeça, para que outro, em cima da carroceria, a puxasse para dentro. Essa tarefa era realizada por colhedores e colhedoras. 
Após a jornada de trabalho prolongada, com uso de esforço físico e condições de trabalho precárias, a maioria dos trabalhadores aproveitava o pouco tempo de lazer dormindo, repousando, assistindo à TV ou DVD, ouvindo rádio e música e permanecendo em casa na companhia de pessoas da família. Os vendedores ambulantes jovens passavam boa parte das horas livres navegando na internet, participando das salas de bate-papo e conversando com pessoas conhecidas. Alguns organizavam churrascos e chamavam amigos e familiares para beber em casa.

Percebeu-se que buscavam atividades que não exigiam atenção, esforço físico e muito movimento. Era comum dormirem enquanto assistiam à TV ou ouviam rádio. Poucos sentiam disposição para fazer alguma leitura. Disseram que o desgaste físico e mental no trabalho era tanto que "não sentiam vontade de fazer nada", só desejavam descansar para repor energias e poder reiniciar o trabalho na próxima semana.

Além do cansaço físico, a falta de dinheiro era outro motivo que limitava as opções de lazer. Quando saíam de casa, era para frequentar bares, principalmente os homens. Consumiam várias garrafas de cerveja, jogavam bilhar, dominó e cartas com os colegas. Era comum alguém da família ir buscá-los, pois estavam muito bêbados para voltar sozinhos. No bairro, havia inúmeros bares que ficavam lotados nos finais de semana. O excesso de bebida alcoólica era preocupante, pois aumentava o número de acidentes de carro, atropelamentos, brigas e violência.

Alguns trabalhadores jogavam futebol, participavam de forrós e festas regionais e passeavam no centro da cidade. Visitavam pessoas da família e amigos eventualmente. As mulheres usavam o tempo de lazer ou de não-trabalho para realizar os afazeres domésticos, como limpar a casa; lavar; passar roupa; cozinhar; costurar; e cuidar dos filhos, entre outros, e fazer "bicos" para complementar o orçamento, vendendo lingerie; montando bijuterias para as fábricas; e fazendo doces e salgados por encomenda. 
Alguns homens ocupavam o tempo livre trabalhando como ajudantes de pedreiro; pintores; e eletricistas, entre outras atividades.

\subsection{Acidentes e violência no trabalho}

Este item pretende discutir as seguintes questões: 1) os acidentes de trabalho típicos; assistência médica; reabilitação física; e retorno ao trabalho; e 2) a violência no trabalho, por exemplo, acidentes de trânsito; atropelamentos; agressões; e tentativas de homicídio, entre outros problemas sofridos pelos pescadores de lagosta, catadores de materiais recicláveis, vendedores ambulantes e colhedores de laranja.

\subsubsection{Acidentes de trabalho}

As condições precárias no trabalho ocasionavam acidentes, como no caso do pescador de lagosta que prendeu uma perna na corrente do motor do barco e a fraturou. Depois desse acidente, com a necessidade de despender mais força nas atividades de pesca, ele prejudicou sua coluna, formando inúmeras hérnias de disco. Ainda jovem e desempregado, acabou aceitando trabalhar como vigia e na manutenção dos barcos, recebendo menos de um salário mínimo por mês.

Outro pescador encontrado sofreu acidente de trabalho, mas continuava desempenhando a atividade. O sujeito teve parte do dedo indicador da mão esquerda 
praticamente decepada quando puxava "manzuás" (armadilhas). O dedo enroscou num ferro e foi cortado ao meio. Os companheiros do barco salvaram o trabalhador, costurando com linha de pesca e agulha comum uma parte do dedo e usaram um pedaço de pano para cobrir o ferimento. Até o fim da temporada de pesca, o pescador bebia "pinga" para suportar a dor, sem parar de trabalhar. Não tinha como retornar à terra para receber a assistência médica necessária.

Quando retornou, foi imediatamente ao pronto-socorro da cidade, pois sentia dores terríveis. Devido à infecção e à gravidade do machucado, teve que amputar o dedo. Os medicamentos foram custeados pelo próprio pescador acidentado e sua família. O trabalhador não teve um dia sequer de descanso e logo retornou para o mar para mais uma pescaria. Comentou que a falta do dedo não prejudicava o desempenho da atividade. Na pesca, o profissional estava sujeito a cortes e perfurações devido à utilização de facas, rede, anzol e outros materiais pontiagudos ou perfurocortantes.

Questionados, os pescadores disseram que alguns barcos possuíam equipamentos de primeiros-socorros, mas que nem sempre havia todos os itens necessários. Também duvidavam da validade dos remédios. Muitos pescadores preferiam levar seus próprios medicamentos (devia ser uma prática a automedicação), pelo menos os mais usados no dia-a-dia, como comprimidos contra a dor, febre, enjôo, disenteria e inflamação, entre outros. Os produtos de higiene, como sabonete, escova e pasta de dente e papel higiênico também ficavam por conta dos trabalhadores.

Por causa dos ventos fortes e ondas gigantes, o barco podia virar, ou a proa quebrar. Existia o risco dos pescadores caírem no mar. É sabido que não adianta saber nadar no mar revolto e que o barco permanece longe da costa. Além disso, há o perigo de acidente de trânsito, isto é, do barco ser atingido por embarcações maiores durante a noite, o que pode causar naufrágios, afogamentos e até mesmo mortes. A maioria das 
embarcações utilizadas na pesca artesanal realizava pesca costeira e muitas não tinham equipamentos básicos de segurança e salvatagem, como rádio comunicador VHF; coletes salva-vidas; bóias; e sinalizador ${ }^{402}$. Um dos pescadores relatou a seguinte experiência:

A gente estava dormindo e de repente fez um barulho grande. A gente acordou e o barco estava afundando, tinha sido atropelado por um navio que não viu a gente. É tudo escuro. Ficamos em cima de um pedaço de madeira durante três dias até um outro barco salvar a gente. Quase morremos... Sem água, comida, debaixo da chuva, do frio, sol. Depois disso, eu nunca mais consegui voltar para o mar. Sinto pavor só de pensar nisto.

Esse acidente de trabalho afastou definitivamente o trabalhador da pesca. Ele nunca mais conseguiu desenvolver a atividade por medo e confessou que ficou traumatizado e até hoje sonha com a tragédia. Hoje em dia, esse pescador trabalha como vigia e ajuda na manutenção dos barcos, em troca de um salário mínimo por mês.

Os catadores de materiais recicláveis ficavam com lesões nos braços, ombros, tórax ou coluna devido ao esforço físico intenso. Em alguns casos, as próprias carroças, ao perder o freio numa descida ou cair em buraco na rua, acabavam ferindo os catadores. Foram encontradas situações em que as rodas passaram por cima dos pés, causando luxação, ou a carroça carregada de materiais atingiu as costas do trabalhador, machucando a coluna vertebral e, para não deixar a carroça virar, o catador teve os olhos atingidos pelo puxador.

Os trabalhadores costumavam sofrer cortes nas mãos devido a vidros e garrafas quebradas, tampas de latas e demais objetos perfurocortantes. Percebe-se que não existe 
um costume em nossa cultura de embalar estes materiais perigosos em papéis de jornais antes de colocá-los na lixeira. Em outro caso, o catador manuseou produtos químicos que estavam na lixeira comum e sofreu queimaduras nas mãos. Um catador conta sua experiência:

Tive um corte profundo no braço por causa de um vidro quebrado. Perdi bastante sangue. Amarrei um pano e mesmo com muita dor puxei a carroça até o albergue. Lá eles me levaram para a Santa Casa (hospital). Levei vários pontos. Tomei os remédios que me deram e continuei trabalhando no dia seguinte com o braço enfaixado. Não dava pra ficar parado. Tinha que trabalhar.

Todos os colhedores de laranja comentaram que sofreram acidentes de trabalho, independentemente do tempo de prática na atividade. Quedas de escada que resultaram em torções, fraturas e lesões nos braços, mãos e pernas, ferimentos nos olhos por causa dos galhos das árvores e picadas de insetos (abelhas, aranhas, escorpiões) foram os acidentes mais referidos pelos trabalhadores. $\mathrm{O}$ ataque de cobras foi lembrado por um dos colhedores da seguinte maneira:

Eu estava trabalhando na roça lá no Paraná. Estava pegando laranja. De repente, vi meu colega caído, segurando a perna onde a cobra tinha mordido. Quando olhei para o lado, vi que tinha outra pronta para dar o bote em mim. Dei um pulo. Foi por pouco. Demoraram para socorrer o rapaz. A cobra era venenosa e ele acabou morrendo no hospital. 
Um ferimento nas mãos por causa dos espinhos é tratado de maneira simples: para o colhedor, é só lavar passar álcool e continuar trabalhando. É comum pisar num buraco e torcer o calcanhar e o joelho. Depois, o trabalhador tem que trabalhar mancando. Um dos entrevistados, que passou por essa situação, estava sem registro e não teve qualquer garantia e direitos.

Mesmo com registro em carteira de trabalho, não poderia ficar afastado, pois havia o medo de ser mandado embora depois, ou de não ser escolhido para as próximas colheitas. Os colhedores de laranja também sofrem acidentes durante as atividades nos barracões. Um dos trabalhadores relatou que:

Quando estava separando as laranjas (que seriam comercializadas), na esteira, a máquina que despeja as laranjas nas caixas puxou minha mão. Saiu a pele, ficou tudo para fora. Voltei aquele dia para casa e, no dia seguinte, estava trabalhando com a mão enfaixada. Não podia parar, senão era mandado embora. Tem que produzir de qualquer jeito.

Ele não faltou um dia sequer no trabalho. Procurou realizar a atividade utilizando-se apenas de uma mão.

Percebeu-se que os colhedores evitavam buscar ajuda médica especializada. Cuidavam dos ferimentos em casa. Realizavam automedicação com antiinflamatórios, analgésicos, colírios para os olhos, compressas com água quente ou gelo. A maior preocupação não estava na reabilitação adequada da saúde, mas no retorno ao trabalho o mais rápido possível. Desse modo, existia o medo da punição no caso das faltas, ou afastamento do trabalho, mesmo para os que tinham direitos trabalhistas. 


\subsubsection{Violência no trabalho}

A pesca de lagosta através do mergulho com compressor de ar é proibida, devido aos riscos da descompressão: pode levar o trabalhador à morte ou causar a doença descompressiva, um mal que acarreta danos físicos graves e irreversíveis ${ }^{403}$. Apesar disso, os pescadores entrevistados comentaram que era comum encontrar mergulhadores do Rio Grande do Norte realizando esse tipo de pesca no litoral do Ceará. Muitas vezes, não respeitavam o período de defeso em que as lagostas estavam em reprodução. A rivalidade e competição entre os pescadores e os mergulhadores eram declaradas. Os segundos tinham facilidade de pescar em maior quantidade. As agressões e ameaças aconteciam durante a atividade de trabalho. Um dos pescadores relatou o seguinte:

Os tempos mudaram. Hoje tem muito barco. Tem também os mergulhadores que vão direto onde as lagostas estão enfileiradas e pegam todas. $\mathrm{O}$ que eles tiram em três dias a gente leva mais de um mês usando os "manzuás" "404. Ainda por cima, dão risadas da nossa cara e apontam arma. Eles ameaçam de morte se a gente abrir a boca, se a gente denunciar. Imagina a nossa humilhação...

Foi possível perceber o temor dos pescadores quando a fiscalização procurou saber onde moravam os mergulhadores da cidade. Nenhum trabalhador teve coragem de contar, por medo de morrer. Disseram que os mergulhadores eram violentos. Apesar da intervenção de órgãos responsáveis pelo meio ambiente, era possível encontrar alguns

403 REIS JUNIOR, Francisco Alves dos. Pesca da Lagosta com o uso de compressor: os riscos do trabalho em condições hiperbáricas. Paper apresentado no ICOH, 2003; FERREIRA, Leda Leal; DONATELLI, Sandra \& REIS JUNIOR, Francisco Alves dos (2003). Análise Coletiva do Trabalho de PescadoresMergulhadores de Lagosta Brasileiros. São Paulo: FUNDACENTRO - Ministério do Trabalho e Emprego. 404 Armadilhas para pescar lagostas. 
barcos com mergulhadores e outros com rede de caçoeira - a chamada pesca de arrastão, também proibida por interferir no ecossistema, por exemplo, causando a destruição da fauna do fundo do mar.

Entre os catadores de materiais recicláveis, os atropelamentos por carros, motos e ônibus foram os principais tipos de acidente de trabalho relatados. Por mais que se colocassem sinalizações, como bandeira ou faixas de cor fluorescentes, os acidentes aconteciam principalmente à noite, enquanto os catadores estavam trabalhando. Nesse horário, apesar do congestionamento diminuir, os carros são dirigidos com maior velocidade. O socorro ao trabalhador nem sempre ocorria. Os entrevistados disseram que era comum ouvir insultos e xingamentos por parte dos motoristas. A maioria das vezes, recebiam ajuda de pedestres e de pessoas de outros veículos. Em relação aos atropelamentos, o Sr. João relatou o seguinte:

Fui atropelado duas vezes na rua. A primeira, na Avenida Brás Leme à noite. Estava andando bem próximo ao acostamento. Um carro passou raspando e só atingiu a carroça. Tive que gastar R\$ 335,00 pelo conserto da carroça. Não aconteceu nada comigo. Na segunda vez, o carro pegou a carroça por trás, pois estava escuro e não dava pra ver nada. Eu levei pancadas nas costas e caí no chão. O motorista prestou socorro, mas o ferimento não foi grave. Mesmo com dor, continuei trabalhando normalmente. Já fui roubado, levaram tudo: roupas, documento e dinheiro. Já roubaram cachorros e carroças, sendo que uma não era minha e eu tive que pagar R\$ 180,00 ao ferro velho.

O problema de ser roubado foi citado pela maioria dos trabalhadores. Agora eles costumam andar com poucos pertences, pois disseram que dinheiro, calçados, roupas, cobertores, panelas, fogareiros e até mesmo animais de estimação eram furtados. O mais preocupante era ficar sem o principal instrumento de trabalho, a carroça. Todos os 
entrevistados passaram por essa experiência pelo menos uma vez e tiveram que alugar outra no ferro velho, pegar emprestada de um colega e comprar outra, pagando em várias prestações.

A violência estava presente também na forma de agressões físicas e morais. Todos os catadores foram unânimes em dizer que haviam sido humilhados e recebidos xingamentos enquanto trabalhavam. Um deles contou que tomou garrafadas e latinhas de cerveja nas costas, atiradas por passageiros de um carro. Outro teve seu cobertor molhado com pinga e incendiado enquanto dormia. Havia brigas entre os próprios catadores por motivo de ponto de coleta, que resultavam em atitudes extremas, como por exemplo facadas e espancamento.

As catadores de materiais recicláveis estavam expostas a todos os tipos de violência. Entre as mulheres entrevistadas, a maioria havia sido estuprada várias vezes. O assunto era delicado e difícil de ser revelado durante a entrevista. Existia um misto de vergonha, revolta e tristeza. Ao procurarem ajuda policial, passavam por uma situação constrangedora, pois acabavam sendo consideradas culpadas pelo ocorrido. Era comum ouvir que "lugar de mulher é em casa e não na rua", que "mulher que vive na rua é vagabunda", ou frases como "arruma um macho para te proteger", entre outras agressões verbais e morais.

As mulheres que sofreram abuso sexual disseram que este fato era comum entre as catadoras. Em primeiro lugar, a atividade do catador é solitária, pesada e executada na rua, onde os trabalhadores ficam expostos à situação de miséria, pobreza e violência, como atropelamentos, tentativas de homicídio, agressões físicas e morais. No caso das mulheres, há também os estupros. Durante o trabalho, as catadoras passavam por humilhações, xingamentos que feriam sua identidade feminina, sendo chamadas de 
"burra de carga"; "puta"; "vagabunda"; e "gostosa", entre outras denominações discriminatórias pelos passantes.

No período da noite aumentava o perigo e o medo da violência. Algumas se arriscavam a dormir isoladas na rua, contando apenas com a sorte. Tinham que mudar de lugar constantemente para não ficarem marcadas pelos agressores. Quando procuravam se aproximar de um catador ou grupo deles, na maioria dos casos, praticavam sexo com um dos homens em troca de proteção. Era comum terem vários parceiros sexuais, correndo risco de serem vítimas de doenças infectocontagiosas e de engravidar. Entre as poucas mulheres entrevistadas, uma era portadora de HIV e outra, sífilis. Citaremos abaixo o relato de duas catadoras:

\section{Eneralda}

Na rua só têm 'nóia'. Eu mesma já fui drogada. Vivia louca para esquecer dos problemas da vida. Olha passei muito sufoco e sofrimento. Só de lembrar minha pressão sobe... Vou te contar uma coisinha só: por causa de um ponto de coleta de lixo, comprei uma briga feia na rua. Foi "bate-boca", baixaria mesmo. Uma noite, estava dormindo quando fui atacada por um homem. Levei duas facadas na barriga (a entrevistada mostra as cicatrizes para a pesquisadora). $\mathrm{O}$ macho da outra, da mulher que eu briguei por causa do lixo, foi se vingar. Fui socorrida pelo carro da polícia e levada ao hospital rápido. Perdi sangue. Pensei que fosse morrer. Fiquei internada um bom tempo, pois tive outras complicações. Nunca mais dormi sossegada. Mudava de lugar, ficava acordada, dormia pouco. Sentia medo de tudo. Aí tomava mais droga ainda (fumava crack, cocaína, maconha) e bebia para espantar o medo. O problema era ter que trabalhar cedo no dia seguinte. Eu não via a hora de amanhecer, porque durante o dia é menos perigoso. Tomo vários remédios que o psiquiatra receitou até hoje. Nunca mais fiquei boa da cabeça. 
Outra coisa que peguei foi sífilis e faço tratamento direto. $\mathrm{Na}$ rua, a gente dorme com um, com outro (silêncio). Sabe tem outra coisa que dói o peito só de pensar. Eu já fui atacada várias vezes (sofreu abuso sexual). Uma vez foi durante o dia... imagina! Estava descansando debaixo da carroça depois do almoço... tirando cochilo e um cara me dominou com uma faca no meu pescoço. Não podia fazer nada. Já me machucaram feio e parei no hospital... Sinto vergonha. Parece que a gente é nada! É esse pessoal "nóia" que mora rua que faz maldades. Sei de muitas histórias por aí com outras mulheres. Hoje estou bem, apesar de ficar triste, pois tenho dois filhos perdidos no mundo (depois a trabalhadora contou que estão presos por roubo e homicídio). Saí da rua, estou na cooperativa, tenho meu cantinho (alugou um apartamento que divide com colegas carroceiros) e luto pra virar a página. Esquecer tudo que passei... Adoro forró, samba nos finais de semana... Estar viva é mais importante.

\section{Dina}

Eu tive quatro filhos e estou esperando o quinto. Estou no oitavo mês de gravidez. Ainda puxo carroça pesando 300 a 400 quilos. Estou bem e o bebê também. Os dois mais velhos, tiraram de mim. O juizado levou. Eles foram para adoção. Os outros dois estão com uma irmã minha. Eu gosto da rua, de trabalhar sozinha, por conta. Só vim para o albergue por causa da gravidez. Eles estão me ajudando. Estou indo ao médico, faço acompanhamento. Estou fazendo o enxoval do bebê com o que ganho do pessoal da igreja e dos outros moradores do albergue. Quero ver se consigo ficar com este filho. Vou cuidar bem...

Entre os vendedores ambulantes, as agressões físicas ocorriam no momento do "rapa" e da fiscalização da prefeitura. Os camelôs corriam para não terem as mercadorias apreendidas e derrubavam quem estivesse pela frente. Os deficientes 
físicos, idosos e mulheres grávidas eram os mais atingidos. Alberto, que era cego, teve a bengala quebrada várias vezes e já fraturou o joelho ao ser empurrado. Um vendedor de doces de 70 anos foi pisoteado após cair no chão, no momento da correria. Ficou com hematomas e dores no corpo por um longo período. Uma vendedora, grávida de sete meses, caiu ao tentar fugir e ainda foi atingida por cassetetes dos guardas municipais. Quase perdeu a criança.

No confronto com a Guarda Municipal, os trabalhadores eram feridos de diversas maneiras: com estilhaços de bombas de gás lacrimogêneo; balas de borracha; sofriam agressões com cassetetes, bolinhas de gude, jatos d'água, pisadas e coices de cavalo, entre outras. As brigas acabavam em prisão para alguns camelôs. Eles recorriam ao Movimento Unido dos Camelôs (MUCA), a advogados públicos ou pessoas conhecidas para serem libertados. Ressaltavam que a prisão não era justa, pois os guardas haviam começado a agressão. Faziam questão repetir que "não eram ladrões, mas sim trabalhadores". Em relação à agressão física, um jovem de 20 anos comentou:

Eu estava fugindo. Eles (Guarda Municipal) fecharam a rua. Ficamos encurralados no meio do quarteirão e não tinha como fugir e onde se esconder. As lojas, o comércio e os edifícios fecharam as portas. Eles vieram em nossa direção e jogaram os cavalos em cima da gente... Foi uma gritaria, pedindo socorro. Ficavam rindo da nossa cara. Muita gente se machucou feio. Depois bateram na gente com cassetetes e correntes. Fomos levados para a delegacia feridos. Só depois a gente passou pelo pronto-socorro. Eu mesmo fiquei cego desse olho (lado esquerdo) por causa de uma bolinha de gude atirada por um guarda numa briga.

Outro jovem de 23 anos relatou o seguinte: 
O carrinho de carregar mantas e colchas cortou o meu pé quando eu fugia do "rapa". Levei pontos no pronto-socorro de Santana e continuei trabalhando. Já levaram minha mercadoria duas vezes. Eu deixei lá, pois não tinha mais de R\$ 300,00 para pagar a multa de apreensão de mercadoria na prefeitura. Eu preferi pagar aos poucos para o dono do caminhão. Peguei outro carrinho, mantas e colchas. Já apanhei feio na 25 de março. Levei muita "porrada" de cassetetes e fiquei com o braço inchado e roxo... Nunca mais quis ir vender lá (a repressão é maior e mais ostensiva).

Um vendedor de milho, que também feriu a perna na fuga contra a agressão dos Guardas Municipais, contou:

$\mathrm{Eu}$ tentei fugir correndo do "rapa". Estava empurrando o carrinho de milho. A roda do carrinho bateu na minha própria perna e quebrou o tornozelo. Tive que engessar a perna e continuar trabalhando com a perna machucada. Os colegas, também camelôs, ajudavam a empurrar o carrinho. Usei muletas. Agora estou bem, mas sinto dor quando esfria. Não fiz fisioterapia... Não tinha tempo para isso. Hah, já perdi o número de vezes em que apanhei de cassetetes... Já fiquei machucado, claro!

Os camelôs sofrem atropelamentos, pois circulam nas ruas, muitas vezes carregando mercadorias e barraca. Outros possuem bancas de venda ou tabuleiros na esquina. Ficam posicionados em pé ou sentados próximos à rua. São atingidos quando ônibus ou carros fazem a curva. Alguns dos entrevistados foram atropelados no trajeto de casa até o local de trabalho. Não se pode esquecer dos acidentes de trânsito sofridos pelos vendedores que, para vender mercadorias, circulam de carro pelos bairros da cidade. A maioria desses trabalhadores já teve a experiência de ser roubado ou 
assaltado. Os ladrões costumam levar dinheiro ou mercadorias e as vítimas não efetivam queixa, nem fazem Boletim de Ocorrência, pois vendem produtos "pirata" ou ilegais (sem pagar impostos).

\subsection{Doenças profissionais e saúde mental dos trabalhadores}

A maioria dos trabalhadores entrevistados relacionou as doenças físicas e o sofrimento psíquico com as condições e organização precária do trabalho. A atividade profissional foi considerada tanto um meio de subsistência e realização pessoal, meio de adoecimento e sofrimento físico e mental. Os entrevistados tinham consciência dos riscos no trabalho, mas disseram ser "obrigados" a aceitar, caso contrário perderiam a oportunidade. Permanecer "sem trabalho" seria deixar a família e a si próprios "morrerem de fome" e perder a dignidade.

\subsubsection{Doenças profissionais}

\subsubsection{Esforço físico e dores, lombalgias}

As atividades dos pescadores, catadores de materiais recicláveis, vendedores ambulantes e colhedores de laranja exigiam força física ou a permanência em posturas 
inadequadas. Devido ao esforço físico excessivo e aos movimentos repetitivos, a maioria dos trabalhadores reclamou de lombalgia, hérnia de disco e dores generalizadas no corpo principalmente nas regiões cervical, ombro, pernas, joelho, braços, punho, tendinite, artrite, reumatismo e varizes.

O mais preocupante era que os sintomas da dor surgiam logo após os primeiros meses de trabalho. Um dos catadores materiais recicláveis comentou o seguinte:

Estou catando lixo há apenas oito meses. Já estou sentindo dores na coluna (região lombar) e nas "batatas das pernas" (panturrilhas). Enquanto estou andando e o corpo está quente, tudo bem, não sinto muito. $\mathrm{O}$ difícil é quando paro. A perna fica ardendo, queimando por dentro. Fazer o quê? Faz parte do trabalho.

O trabalho dos pescadores de lagosta exigia muita força física, pois o trabalhador precisava transportar peso excessivo. As tarefas de transportar carga, tirar "manzuás"405 (armadilhas de lagostas) do mar, pegar a caixa do gelo do chão, carregar o bloco de gelo, carregar o pescado, pegar o tambor de água e carregar o galão de óleo, nem sempre eram executadas de maneira adequada. Os trabalhadores sofriam torções, lesões musculares e danos à coluna devido ao esforço, chegando até mesmo a acidentes com fraturas em várias partes do corpo como: pulso, braço, perna e pé.

Alguns pescadores reclamaram de dores nas mãos, no pulso e nas costas - o que pode estar relacionado à Lesão por Esforços Repetitivos (LER). Os trabalhadores faziam o mesmo tipo de esforço durante um longo período de tempo e permaneciam muitas horas, por vários dias seguidos, desempenhando a mesma atividade, geralmente sem pausas para descanso, sem mudança de posição ou de movimento, causando assim 
lesões ${ }^{406}$. O preconceito cultural estava presente quando associavam as dores com a idade, isto é, com a velhice, e não com a atividade de trabalho. Esse entendimento dificultava a tarefa de convencê-los de que na verdade estavam doentes e necessitavam de cuidados, precisavam fazer alongamento e pausas no trabalho.

\subsubsection{Cegueira}

A exposição excessiva ao sol prejudicava a visão dos pescadores, que comentaram ter medo de ficarem cegos. Durante a entrevista, apontaram para um pescador e comentaram que ele já não enxergava quase nada e não conseguia mais trabalhar. O reflexo dos raios do sol no espelho d'água, com o passar dos anos, pode ocasionar ceratites, catarata, pterígio e até mesmo cegueira ${ }^{407}$.

\subsubsection{Alergias, feridas na pele}

Os colhedores de laranja protegiam o corpo do sol para evitar alergias e lesões na pele. Estavam acostumados com as vestimentas e não sentiam calor. Alguns relataram que tiveram coceiras na pele por causa do agrotóxico quando começaram a trabalhar na colheita. Os vendedores ambulantes buscavam proteção permanecendo

406 Quando as roldanas não funcionavam, os pescadores tinham que retirar os "covos" ou "manzuás" do mar de maneira manual. Eram usados "ganchos" como ferramentas para puxar a armadilha. Cada "covo", junto com as lagostas molhadas, pesava em média 40 quilos. A tarefa costumava ser realizada por dois pescadores ao mesmo tempo. O movimento contínuo de flexões e o esforço físico despendido para a retirada dos "covos" prejudicavam as articulações, principalmente na região lombar e nos membros superiores (ombros, cotovelos e mãos). 
debaixo das marquises ou de guarda-sóis. Os catadores de materiais recicláveis usavam apenas boné e não tomavam demais cuidados, apesar de ficarem longos períodos expostos ao sol. Os catadores comentaram ter micoses, feridas, sarnas, piolhos e outras doenças de pele por falta de higiene pessoal, pois não tomavam banho e trocavam de roupa regularmente.

Os pescadores disseram cobrir o corpo todo para se protegerem do sol, mas que devido ao calor e à umidade, acabavam trabalhando com pouca roupa. A intensidade da luz solar sobre a pele com resquícios de sal e a brisa marítima causavam feridas, escaras, rachaduras e dermatites. A permanência constante dos pés no chão molhado do barco e o fato de não usarem calçados adequados provocava micoses.

\subsubsection{Dor-de-cabeça, sinusite e bronquite}

Os camelôs, catadores de materiais recicláveis, colhedores de laranja e pescadores reclamaram de problemas nas vias aéreas superiores. A maioria se referiu à rinite, sinusite, bronquite e dor-de-cabeça como males comuns. A mudança brusca de temperatura (calor e frio num mesmo dia) provocava dores de cabeça e crises de bronquite nos entrevistados. Os vendedores ambulantes e catadores relacionavam as alergias à poluição provocada pelo excesso de carros nas ruas.

Os colhedores disseram ficar doentes por causa da poeira e dos agrotóxicos usados para evitar pragas nos pés de laranja. O produto químico causava coceiras no corpo, ardência nos olhos e falta de ar. Os bóias-frias apresentavam rachaduras nos lábios e secura na boca constantemente. Bebiam água para diminuir o incômodo. A situação piorava quando chovia ou ventava logo após a pulverização com o veneno. Um 
trabalhador de mais de 70 anos, que estava há cinco anos na colheita da laranja, havia trabalhado a "vida inteira" no corte de cana-de-açúcar, tendo sido "expulso" por não conseguir atingir as metas de produtividade por causa da idade e do desgaste físico. Ele disse o seguinte:

Eu tenho bronquite crônica. Já fui parar no hospital várias vezes. No corte da cana era pior por causa da queimada. Era só fumaça e fuligem. A minha alergia começou daquela época. Depois, na (colheita da) laranja, tem o veneno e a poeira. Ficam cheios de pó os galhos e as frutas. Tomo remédio apenas quando tenho crise mais forte. Sinto falta de ar sempre.

\subsubsection{Saúde mental no trabalho}

\subsubsection{Sofrimento no trabalho}

A maioria dos pescadores, catadores de materiais recicláveis, vendedores ambulantes e colhedores de laranja disse ter insônia, sono irregular, cansaço físico e mental crônico, hipertensão, ansiedade, nervosismo, gastrite, úlcera e falta de apetite. Os trabalhadores comentaram que os sintomas físicos e o sofrimento psíquico estavam relacionados com a atividade de trabalho. Desse modo, é possível confirmar que os trabalhos desenvolvidos não se tratam simplesmente de atividades braçais, que qualquer sujeito com disposição física poderia executar. São necessárias atenção e qualidades de inteligência prática para executar as tarefas e resolver problemas. Além disso, é 
importante considerar os aspectos subjetivos, isto é, o sentido do trabalho para os sujeitos.

A jornada de trabalho prolongada, durante praticamente todos os dias da semana; o ritmo de trabalho intenso; as poucas pausas; a pressão dos donos de barcos e dos "gatos" e empreiteiros para aumentar a produção; os ganhos incertos; o pouco tempo para o sono e descansos; e a falta de férias levava os trabalhadores a um estado de atenção, alerta constante e estresse. Essa situação perdurava mesmo depois do trabalho. Sentiam dificuldade em relaxar, estavam sempre tensos, preocupados. Os sujeitos comentaram que não conseguiam relaxar, abstrair, "desligar" e pensar em outra coisa a não ser no trabalho do dia seguinte; nas metas a cumprir; na produção; nos relacionamentos sociais conflituosos; na falta de dinheiro; no pagamento de dívidas; nos riscos de acidentes e doenças a que estavam sujeitos; no medo do futuro; na falta de trabalho; no envelhecimento; em ficar incapacitado; no desemprego; e na violência, entre outros problemas.

Os pescadores sentiam medo de não ter lagostas para pescar; de produzir pouco e ser excluído da equipe; de tempestades, vento forte, ondas gigantes; do barco virar; de caírem no mar; de serem atropelados por embarcações maiores, entre outros. Ficavam atentos a qualquer barulho que pudesse identificar a aproximação de navios, principalmente à noite, o que prejudicava a qualidade do sono e o repouso. Na pesca com os "manzuás" ou "covos", era exigida alta carga cognitiva, devido à atenção para os locais onde as "gaiolas" eram depositadas e para seu manuseio no momento de utilização - os pescadores tinham que calcular, por exemplo, a maneira de colocar o "covo" para que as lagostas adultas entrassem e ficassem presas na armadilha e pensar em como consertar os "manzuás" em caso de danos. Como os barcos costumavam 
mudar de local em busca de mais lagostas, eles tinham que ter noção dos locais exatos para a colocação dos "manzuás" e sinalizadores (bóias de isopor).

O sono irregular; as poucas horas de repouso; o medo da violência e de roubos; o risco de atropelamentos; as humilhações; agressões verbais e físicas; o medo de não encontrar materiais recicláveis para coleta; de não vender as mercadorias; da fiscalização; o congestionamento; e o trânsito intenso na rua afetavam a saúde física e mental dos catadores e camelôs. Além dos problemas de saúde referidos acima, foram encontrados casos de soropositivos ao HIV e de pessoas com distúrbios psiquiátricos graves entre os entrevistados. Havia preocupação, pois os sujeitos não faziam acompanhamento médico. Os catadores Luzia, portadora de esquizofrenia, e Luís, portador de HIV, ambos moradores de rua, disseram que:

\section{Luzia}

Eu não sei o que tenho direito. Só sei que fui internada no Hospital Psiquiátrico do Mandaqui duas vezes e uma vez no Hospital Vera Cruz. Falam que tenho psicose. É assim que se fala? (a catadora pergunta para a pesquisadora). Sei lá... Às vezes fico fora de mim, quebro tudo que vejo pela frente. Acho que tem gente querendo me matar (delírios). Viro um bicho. Depois passa. Minha família não me quer por perto. Eles têm raiva por causa de meu passado. Já bebi, já tomei droga demais. Tive vários homens, casamentos... Sempre gostei da rua, de ficar na rua... Minha irmã criou minhas três filhas. Elas são moças. Tem até casada e eu sou avó. É difícil eu encontrar com eles. Moram muito longe. Hoje não bebo mais e não tomo droga. Não tomo os medicamentos da médica e parei de ir às consultas... Não adianta. Estou na pior. Não consigo andar. Um carro atropelou minha carroça e eu machuquei o pé. A roda da carroça com peso e tudo passou em cima do meu pé (o pé estava enfaixado com uma gaze suja). Estou sem carroça. Pego os lixos 
em saquinhos pequenos e levo até o ferro velho pra vender. Não consigo andar direto, vou mancando. Tem um colega carroceiro que às vezes ajuda e leva o lixo pra mim. Tenho uma prima que gosta de mim e me ajuda quando preciso com dinheiro ou quando tenho crise. Quando estava boa e conseguia andar, ia aos domingos na casa dela.

\section{Luis}

Eu tive paralisia infantil e fiquei com a perna torta. Mesmo assim, puxava carroça. $\mathrm{O}$ peso da carroça forçou meu joelho e acabou quebrando. Hoje em dia não puxo mais carroça tenho que pagar um ajudante, $\mathrm{R} \$ 60,00$ por mês. $\mathrm{Eu}$ vou junto, segurando numa muleta. Peguei AIDS na rua não sei como. Se foi por droga (dividindo seringa) ou com mulheres. Fui até a Santa Casa (hospital) mas não consegui continuar o tratamento. Como vou até lá desse jeito? Não consigo andar direito. Os remédios estragam o estômago, fazem mal e eu esquecia de tomar. Dava muito trabalho. Tenho que trabalhar. Morrer vou morrer mesmo. Decidi deixar como está. Vou levando a vida. Quero receber meus direitos (LOAS), pois sou deficiente físico. Estou pedindo cadeira de rodas na igreja de Santana. Você acredita que roubaram a minha outra cadeira de rodas? Estou sem documentos. Preciso regularizar para poder pedir o $\operatorname{LOAS}^{408}$.

A minoria buscava tratamento nas Unidades Básicas de Saúde ou em hospitais públicos $^{409}$, apenas aqueles com os casos mais graves. Consideravam perda de tempo, pois sabiam que não seria possível dar continuidade ao tratamento devido ao trabalho.

\footnotetext{
408 LOAS é um benefício de um salário mínimo mensal pago às pessoas idosas com 65 anos ou mais, conforme o estabelecido no Art ${ }^{\circ} .34$ da Lei $n^{\circ} 10.741$, de $1^{\circ}$ de outubro de 2003 - o Estatuto do Idoso, e às pessoas com deficiência, incapacitadas para a vida independente e para o trabalho. Está previsto no artigo $2^{\circ}$, inciso IV, da Lei Orgânica da Assistência Social - LOAS (Lei no 8.742 de 7 de dezembro de 1993) e regulamentado pelo Decreto $n^{\circ} 1.744$, de 8 de dezembro de 1995 e pela Lei $\mathrm{n}^{\circ}$ 9.720, de 20 de novembro de 1998, em vigor desde $1^{\circ}$ de janeiro de 1996. Ministério do Desenvolvimento Social e Combate à Fome (MDS) e Instituto Nacional do Seguro Social (INSS).

409 A maioria dos catadores de materiais recicláveis entrevistados nessa pesquisa recorriam ao Centro de Saúde Escola Barra Funda e ao Hospital da Santa Casa de Misericórdia de São Paulo em caso de necessidade.
} 
Nas instituições de saúde, recebiam, quando disponíveis, os medicamentos necessários, como remédio para pressão alta; analgésico; antiinflamatório; e calmantes, entre outros.

Comentaram que o jeito era "deixar a dor pra lá" "esquecer que ela (dor) existe", descansar um pouco, consumir bebida alcoólica e drogas em geral e continuar trabalhando. Percebeu-se que tanto na atividade de trabalho, como nos momentos de descanso, o consumo de drogas e bebidas possibilitava esquecer os sofrimentos no corpo e na vida. $\mathrm{Na}$ verdade, os trabalhadores eram destituídos do direito de adoecimento. Não podiam parar de trabalhar, não tinham tempo para buscar assistência médica, caso contrário, não tinham como ganhar o "pão de cada dia". Neste caso, os princípios de "quem não trabalha, não come" e "riqueza de pobre é saúde" eram muito fortes na vida desses homens e mulheres que lutavam o tempo todo para se afirmarem como trabalhadores honestos e dignos.

O modo de vida era considerado "normal" e "comum" pelos trabalhadores. Disseram que "sempre viveram assim" e que estavam acostumados com os problemas no trabalho, família, saúde e falta de dinheiro, entre outros. A saída era ignorar essas denominações, fazendo uso de drogas, bebidas ou, em alguns casos, enlouquecendo e fugindo da realidade. Ficou claro o mecanismo de negação do sofrimento, pois entre palavras faziam questão de ressaltar que "estava tudo bem"; que "a situação que viviam era boa, pois apesar de tudo tinham o que comer, um canto para dormir e trabalho. Não precisavam roubar". Outros diziam que era "a vontade de Deus" e alguns nem se permitiam pensar no que mais os incomodava no trabalho e na vida. Preferiam ficar calados, pois não encontravam resposta. Ela estava contida, para que não sentissem a dor da situação vivida.

Os pescadores e os catadores de materiais recicláveis foram unânimes ao relatar o sofrimento mental decorrente do distanciamento da família e dos amigos. O 
isolamento social; a impossibilidade de conviver com entes queridos, de acompanhar o nascimento e crescimento dos filhos; a saudade da companhia da esposa ou namorada; a falta de relacionamento sexual; e o medo da traição os deixavam tristes e deprimidos. Como estratégias defensivas ${ }^{410}$, estabeleciam um pacto de silêncio, que significava ser proibido comentar estas questões no grupo. Toda atenção era voltada para a rotina de trabalho e para solucionar questões práticas do dia-a-dia. Aguardavam com ansiedade o reencontro com a família.

A situação dos catadores era mais grave, pois a maioria tinha perdido vínculos com pessoas da família há muito tempo. Sentiam-se culpados e envergonhados pelo fracasso na vida. Não queriam que entes queridos soubessem que eram "catadores de lixo". Pareciam guardar segredos e evitavam falar do passado. Esse momento costumava ser tenso e causar incômodo. Os motivos eram os mais variados, como abandono por causa de drogas, alcoolismo e doença mental; roubo; homicídio; prisão; fracassos; falência nos negócios; e traição, entre outros. A solidão era constante, pois trabalhavam e viviam sozinhos. A integração social era circunstancial ou temporária, enquanto ficavam em albergue, ou quando permaneciam em grupo à noite, como forma de defesa contra a violência. $\mathrm{O}$ apego afetivo aos cachorros era uma forma de minimizar o sofrimento pela falta de relações sociais.

Em termos de estratégia defensiva ${ }^{411}$, percebeu-se que a atividade de pescador de lagosta é uma profissão predominantemente masculina em que é exigida uma prova de força física, coragem, iniciativa, disposição para o trabalho e bravura para aguentar as vertigens, tonturas, enjôos e o sentimento de medo e insegurança. Ao ouvirem a pergunta sobre o medo, todos riram, dizendo que a pessoa não podia demonstrar qualquer fraqueza, pois seria colocada para fora do grupo nas próximas viagens.

410 DEJOURS,C. (1987). A loucura do trabalho: estudo de psicopatologia do trabalho. São Paulo: OBORÉ Editorial. 411 C. DEJOURS (1987). 
Aqueles que admitiam sentir medo eram considerados homens "fracos", que não serviam para enfrentar as agruras no mar. Assim mesmo, a maioria confessou que sentiu vertigens e enjôos, principalmente nas primeiras viagens e nos momentos de tempestade e ventania em que o barco balançava.

A defesa psíquica também se manifestou quando a pesquisadora questionou o uso de hidratante e protetor solar e óculos de proteção contra o sol, devido a riscos para a saúde. Os trabalhadores alegaram que não estavam acostumados a ter estes cuidados e que a própria atividade de trabalho dificultava adotar estas medidas de prevenção. Nesse caso, era importante pensar em formas mais efetivas de conscientização sobre os riscos de exposição ao sol, talvez com palestras proferidas por especialistas na área de dermatoses ocupacionais periodicamente. Um dos pescadores disse em tom de gozação:

Ah, ou a gente fica passando hidratante, protetor solar toda hora, ou a gente trabalha. Não dá tempo, é muita correria. Esse trabalho não dá para ter pele sensível não (risadas dos integrantes do grupo) e usar óculos não dá. A lente fica embaçada, os óculos caem no chão e quebram [os argumentos pareciam dizer que estas medidas de prevenção não combinavam com a atitude de "macho" e de bravura].

O desgaste físico e psíquico fazia com que muitos não conseguissem mais desenvolver sua atividade após os 50 anos de idade. A aparência física de um pescador após 30 anos no mar é de alguém bem envelhecido. Esse fato foi observado entre os catadores, colhedores de laranja e camelôs. O trabalho pesado, os efeitos do sol na pele e o estresse físico e emocional contribuem para o envelhecimento precoce do trabalhador. Na fala de um dos pescadores, ficou claro o desalento e a preocupação com o futuro: 
Olha aqui a gente só serve quando dá prá trabalhar. Tem que ter força, saúde, senão os mestres não escolhem mais a gente. Eles pegam os mais fortes, que não têm problema de saúde e que não criam encrenca. $O$ trabalho é tão puxado que a gente não aguenta por muitos anos. Dá pra trabalhar até uns 50 anos, depois gente não agüenta, está cansado, com problemas na coluna, nos braço e ombros. Agora tem dono de barco que gosta de levar pescador com experiência (eram os pescadores com mais de 50 anos sendo que alguns possuíam entre 58 a 60 anos), que conhece o mar. Pelo menos um deles vai no barco.

A questão da perda da força física em função do desgaste no trabalho e do envelhecimento era importante para inserção dos trabalhadores em determinadas ocupações na trajetória profissional. Quando jovens, conseguiam trabalhar em várias funções, como metalúrgicos; pedreiros; carpinteiros; pescadores; cortadores de cana-deaçúcar; colhedores de laranja; empregadas domésticas; e lavadeiras, entre outras. Percebeu-se que a maioria deixou de ser assalariada na maturidade e na velhice. Faziam "bicos" e trabalhos temporários, como camelôs; catadores de materiais recicláveis; vigias; montadores de bijuterias; entregadores de jornal e anúncios; e carregadores de placas, entre outros.

\subsubsection{Prazer no trabalho}

Todos comentaram que apesar do trabalho precário, árduo e pouco valorizado, existiam aspectos que proporcionavam satisfação. O prazer no trabalho estava relacionado à preservação da natureza; a sentirem-se úteis para a sociedade; a cuidar do 
meio ambiente; a ganhar dinheiro com "seu próprio suor"; a ocupar a cabeça de maneira proveitosa; a não ficar parado; e a exercitar o corpo, entre outros motivos. Os trabalhadores por conta-própria, vendedores ambulantes e catadores comentaram que gostavam da "liberdade" de não ter chefia, patrão e não ficar sob vigilância constante. Ter horário flexível, apesar das jornadas prolongadas, ganhar tudo o que produziam e ter rendimentos maiores eram motivos de grande satisfação.

Gostavam de trabalhar ao ar livre, em "lugar aberto", ao contrário do ambiente fechado de fábrica. Os colhedores e pescadores comentavam de maneira saudosa a época da infância ou o início da adolescência, em que "mexiam" na terra. O trabalho na lavoura consistia em tradição familiar, isto é, o "saber fazer" era transmitido de geração em geração. Os pescadores de lagosta e colhedores de laranja eram os que tinham maior identificação com a profissão. Alguns disseram que não trocariam o seu trabalho por outra atividade, mesmo ganhando mais.

Vários entrevistados valorizavam os relacionamentos sociais e a convivência social. Para alguns, essas amizades construídas no ambiente de trabalho tinham sentido de solidariedade e de pertencer a um grupo. O respeito obtido pelo público e os clientes era importante. Gostar de fazer negócios, vender, conhecer pessoas novas e agradar os fregueses eram as características mais destacadas pelos trabalhadores. Os comentários de um camelô e de um catador de material reciclável foram os seguintes:

Gosto da amizade que faço aqui. Sou camelô há muitos anos e conheci muita gente. Tenho alguns amigos que encontro até hoje. Deixaram de ser vendedores e foram embora, mas sempre voltam para fazer visita, para ver a gente. Gosto de falar com os fregueses. Tenho fregueses há anos. Só compram aqui. Eu ligo para casa dela (uma cliente) para avisar que chegou o que ela gosta. Depois passa aqui. Gosto de agradar os clientes. Ver os 
clientes satisfeitos. Tem gente que vem para dar um 'oi' e bater papo. Não compram nada, mas se preocupam com a gente. Uma pessoa já trouxe remédio para mim porque disse que eu estava doente. Outro dia ganhei presente... Isso é muito bom.

Tem gente ruim, mas tem gente muito legal. Eu conheço muitas pessoas que gostam de ajudar. Elas guardam papel e papelão para mim. Passo nos escritórios, lojas e prédios e está tudo guardado. Ganho roupas, sapatos e comida. Sou conhecido pelo pessoal desse bairro. Estou aqui há muito tempo. Gosto de dividir comida e tudo que tenho com os meus colegas de rua. As pessoas passam, vão embora, mas é legal dar as coisas, dividir, fazer o bem. Também já fiz amizade com o pessoal nos albergues. Nunca mais encontrei, mas foi muito bom na época...

Os pescadores de lagosta e colhedores de laranja trabalhavam com pessoas conhecidas e vizinhas. As famílias conviviam há longa data. A proximidade fazia com que os laços sociais fossem fortes. A amizade permanecia fora do trabalho. Os trabalhadores recebiam apelidos construídos pelo grupo. Os colhedores brincavam jogando pedaços de laranja um no outro, por exemplo. Já os pescadores disseram que o humor, as gozações e a solidariedade ajudam nos momentos difíceis, contribuem para a integração do grupo.

Por outro lado, alguns trabalhadores, principalmente catadores e camelôs, disseram gostar apenas do dinheiro que recebiam para sobreviver e que não se identificavam com a ocupação. Aquela atividade era como outra qualquer e apenas um meio de sobrevivência. Não havia qualquer sentido no trabalho, além do dinheiro. Parecia que eram a única atividade que restava para pessoas como eles, isto é, sem estudo e "velhos". A melhor atitude era não pensar muito, "não encher a cabeça", "não 
esquentar a cabeça”, pois nada iria mudar. O destino estava selado na pobreza e miséria. Tais trabalhadores demonstravam sentimento de desesperança mais que conformismo.

\subsection{Expectativas para o futuro}

Adquirir ou reformar casa própria e ter um lugar fixo de moradia eram expectativas da maioria dos trabalhadores. Comprar ou trocar de carro, eletrodomésticos, televisão e aparelho de som, entre outros objetos, estavam entre os desejos dos entrevistados, assim como adquirir meios de transporte - como a "perua Kombi" ou a caminhonete - para utilizar no trabalho. Ter um pedaço de terra para plantar e criar gado no local de origem, principalmente no Nordeste, era a meta de alguns sujeitos. Estavam saudosos dos familiares e dos modos de vida que tiveram na infância.

Alguns nutriam a esperança de receber aposentadoria ou algum benefício na velhice para sobreviver, pois não haviam tido condições de poupar qualquer dinheiro. Dessa forma, planejavam retornar aos estudos e buscar qualificação, principalmente os mais jovens. O objetivo era conseguir uma melhor recolocação no mercado de trabalho, tanto na iniciativa privada, como em órgãos públicos. Preferiam o emprego público, ou com carteira de trabalho assinada, que possibilitava ter acesso aos direitos. Outros não acreditavam que fosse possível melhorar os rendimentos.

Os trabalhadores com poucas chances de inclusão no mercado formal pensavam em abrir pequenos negócios ou fazer "bicos" em atividades que não exigissem tanto esforço físico. Ficavam extremamente preocupados com o dia em que não conseguiriam 
mais trabalhar devido à velhice, doenças e outros problemas. A maioria dos sujeitos queria ter "saúde, força, disposição, cabeça boa para continuar trabalhando", para comer, ter um teto para viver, comprar aquilo de que gostava e ter tempo para diversão. Todos disseram ter o desejo de construir uma família e reencontrar parentes distantes. Queriam ver os filhos e netos estudando para ter uma profissão e futuro melhor. Não desejavam aos descendentes a mesma trajetória profissional e de vida que tiveram. 


\section{CONSIDERAÇÕES FINAIS}

Um dos impactos das políticas neoliberais de ajustamento econômico no mundo do trabalho é a destruição cada vez maior do emprego formal, causando o aumento do desemprego e, em consequência, de um segmento da informalidade no mercado de trabalho. O trabalho informal, que nas décadas de 60 e 70 era considerado como uma situação transitória, fadada a desaparecer com o avanço e desenvolvimento do capitalismo no Brasil, torna-se - pelo contrário - condição permanente no nosso moderno e flexível mercado de trabalho.

O trabalho informal configura-se como uma regra normativa do mercado e se constitui nas tradicionais estratégias de sobrevivência de trabalhadores desempregados devido à reestruturação produtiva e às transformações econômicas, principalmente nas décadas de 80 e 90 . A crise financeira provoca a "corrosão do trabalho contratado" e a “erosão do emprego regulamentado" que foram dominantes até então no século 20 e que vêm sendo suplantados por diversas formas alternativas de trabalho e subtrabalho que frequentemente "substituem" o trabalho formal, gerando novos e velhos mecanismos de intensificação e mesmo de autoexploração da atividade produtiva. Os modos de precarização do trabalho, o avanço tendencial da informalidade e o desemprego acentuam a tragédia social em que estamos envolvidos ${ }^{412}$.

As estatísticas oficiais apresentam um quadro preocupante. A Organização Internacional do Trabalho (OIT) antecipou que, dada a ampliação da crise, "até 2,4 milhões de pessoas poderão entrar nas filas do desemprego regional em 2009"413, somando-se aos quase 16 milhões hoje desempregados, sem falar no desemprego oculto

412 ANTUNES, Ricardo (2009). Os dilemas do trabalho no limiar do século 21. CULT, nº 139, Ano 12. www.revistacult.com.br. Consulta realizada em $06 / 10 / 2009$. 
e em outros mecanismos que mascaram as taxas reais de desemprego nas regiões da América Latina e do Caribe.

Minha pesquisa destaca os trabalhadores por conta-própria, trabalhadores autônomos, trabalhadores temporários e os assalariados sem carteira nos espaços da cidade, do campo e do mar. As formas de trabalho informal que configuram este segmento não são novas e fazem parte da "velha informalidade". A questão é como essa "velha informalidade", representada pelas ocupações tradicionais, faz parte da "nova informalidade", decorrente do desemprego nas décadas de 80 e 90, e como ela está sendo adequada ao atual padrão de acumulação capitalista.

As atividades informais dos vendedores ambulantes e dos catadores de materiais recicláveis estudados, apesar de possuírem características de atividade "autônoma" e “independente", na verdade, explicitam a relação de subordinação à produção capitalista. Os camelôs vendem produtos sem impostos, adquiridos nas distribuidoras que representam grandes empresas nacionais e internacionais, principalmente as de origem chinesa. Raras vezes, podem ser observadas mercadorias de produção genuinamente artesanal.

Os catadores de materiais de reciclagem contribuem diretamente para 0 desenvolvimento das indústrias de reciclagem, como a indústria de alumínio; papel; e plásticos, entre outras - empreendimentos de grande porte que contam com a produção do trabalho "autônomo" de milhares de catadores de materiais de reciclagem, pertencentes ou não a cooperativas. No momento de minha pesquisa, várias cooperativas deixaram de funcionar devido à crise mundial e à desvalorização do valor dos produtos. Muitos catadores procuraram trabalhar em outras ocupações e alguns continuam nessa atividade, vendendo os materiais para ferros-velhos ou cooperativas maiores e mais estruturadas. 
Os trabalhadores autônomos e as indústrias estão situados em pontas distintas da cadeia produtiva. As empresas se eximem de qualquer responsabilidade pela mão-deobra daquele que fornece a matéria-prima para sua produção. A mesma constatação é observada entre os pescadores e os trabalhadores agrícolas, que são considerados “trabalhadores temporários". A produção da pesca e da colheita atende à demanda das indústrias de pescados, de suco de laranja e das empresas de exportação. Os pescadores e colhedores de laranja não possuem qualquer vínculo de trabalho direto com as indústrias. São mão-de-obra barata e explorada, que se submete a condições de trabalho precárias para poder sobreviver.

Neste estudo, os trabalhadores rurais estão ocupados na colheita da laranja, da cana-de-açúcar, da mandioca e do milho, entre outras culturas, durante o ano. Já os pescadores trabalham na pesca da lagosta durante o período permitido por lei. $\mathrm{O}$ importante é perceber, tanto entre os colhedores, como entre os pescadores, a existência de vínculos de trabalho permanentes com empreiteiros, "gatos" e os donos de barcos (conhecidos como "armadores"). Isto significa que os trabalhadores são mão-de-obra terceirizada e subcontratada pelas grandes indústrias. A atividade informal, nesses casos, possui características de trabalho assalariado, constatando-se uma relação de assalariamento. O fator mais agravante dessa situação é a ausência do vínculo empregatício formal com as empresas e, consequentemente, o não-reconhecimento dos direitos dos trabalhadores.

Por esse ângulo, percebe-se a crescente participação do trabalho informal nas esferas produtivas e improdutivas do capital. A imbricação de atividades "autônomas"; "independentes"; "assalariadas" é a regra no mercado. A visão de um mercado segmentado em setor formal, setor informal e setor marginal não corresponde aos resultados de minha pesquisa. 
A utilização das trajetórias ocupacionais como instrumental analítico contribui para a compreensão e a discussão crítica dos conceitos teóricos sobre trabalho informal, empreendida em meu estudo. É possível observar que tanto "ao longo do tempo e em vários espaços", quanto em "um mesmo ponto do tempo e do espaço", o desenvolvimento de múltiplas atividades, de maneira concomitante ou sequencial, não permite uma análise a partir de categorias tradicionais e de sistema classificatório limitado.

A análise das trajetórias ocupacionais possibilita recuperar não só a sucessão de atividades desenvolvidas ao longo da vida, como também sua repercussão sobre a subjetividade do trabalhador. Sendo assim, as trajetórias deixam transparecer as preferências, os desejos, o prazer, o sofrimento, as expectativas e as ações pessoais, políticas e profissionais que se desenvolvem ao longo de uma vida de trabalho. A utilização mais ampla das trajetórias ocupacionais mostrou a constante mutação no trabalho por que passa o trabalhador. Seguindo a mesma linha de raciocínio, podemos estabelecer que "a consciência de classe e as ações econômicas e políticas por ela determinadas são o resultado da acumulação de experiências ao longo de uma vida enriquecida por múltiplas e diferenciadas atividades" ${ }^{414}$.

O "estar trabalhador informal", "estar trabalhador autônomo" ou, "estar trabalhador assalariado com carteira" revela a passagem por inúmeras ocupações formais e informais e a mudança constante a que os trabalhadores estão submetidos durante sua trajetória. A passagem por ocupações transitórias, que muitas vezes se tornam permanentes, interfere na experiência subjetiva dos trabalhadores e na construção da identidade social desses sujeitos.

414 MALAGUTI, Manoel Luiz (2000). Crítica à razão informal: a imaterialidade do salariado. São Paulo: Boitempo; Vitória: EDUFES, 173p. 
Parece inusitado pensar em organização dos trabalhadores "autônomos" e “independentes". É algo raro, mas que existe na forma de movimentos sociais, sindicatos e associações. Tais instâncias representativas lutam pela regulamentação da profissão, pelo respeito ao trabalhador e contra a violência. Os movimentos sociais costumam unificar suas bandeiras de luta, como é o caso do Movimento Unidos dos Camelôs (MUCA) e do Movimento dos Trabalhadores Sem Teto do Rio de Janeiro. Devemos ressaltar a ação do Sindicato dos Trabalhadores Informais da Central Única dos Trabalhadores, que visa organizar as categorias informais na cidade de São Paulo. As manifestações são circunstanciais e o número de participantes efetivos é variável.

Apesar da experiência de organização, a maioria dos entrevistados em meu estudo prefere estar empregado, ser assalariado com carteira e usufruir dos direitos trabalhistas e previdenciários e dos benefícios que as empresas oferecem. A condição salarial é um sonho a ser conquistado, mesmo que as condições para atingir essa meta sejam precárias. Os trabalhadores informais não possuem um projeto coletivo, de longo prazo, de transformação da sociedade. Eles são imediatistas e querem um emprego para poder consumir e satisfazer suas necessidades de sobrevivência.

É possível constatar que a inserção e permanência nessas ocupações informais e precárias ocorre por falta de opção. Um dos aspectos mais ressaltados pelos entrevistados é a falta de proteção e de direitos sociais e trabalhistas na ocupação informal. O ganho por produção e um bom rendimento, muitas vezes maior do que os dos trabalhadores contratados, parece ser um atrativo para os jovens, mas na maturidade e na velhice, o "bico", o subemprego, o trabalho temporário e a atividade informal deixam de ser vantajosos. A falta de uma aposentadoria e a necessidade de continuar na ativa, seja para complementar o valor do benefício, para o autossustento ou para manter os filhos e netos, entre outros familiares, impossibilita aos idosos parar de trabalhar. 
Tais situações são parte da vida desses cidadãos de "segunda categoria". Os trabalhadores com baixa escolaridade e qualificação e idade avançada possuem poucas perspectivas de conseguir uma melhor inserção no mercado de trabalho.

A rotatividade de trabalho ocorre entre ocupações informais e precárias. $\mathrm{O}$ subemprego provisório-permanente, a instabilidade no trabalho, a insegurança financeira, a pobreza e a ausência de direitos acabam sendo a dura realidade de milhões de brasileiros, tanto homens, quanto mulheres, idosos e jovens. $\mathrm{O}$ trabalho informal e suas consequências sobre a saúde dos trabalhadores, os acidentes de trabalho e as doenças profissionais são motivos de preocupação de organizações nacionais e internacionais.

As políticas, nacionais e internacionais, de saúde e segurança na economia informal não conseguem mapear exatamente como vivem e trabalham esses sujeitos, que se encontram à margem dos direitos de cidadania. Meu estudo propôs compreender as trajetórias dos trabalhadores informais e suas condições de vida, trabalho e saúde, com o propósito de contribuir para a elaboração de políticas públicas voltadas a essa população. Um aspecto importante é pensar o tipo de inclusão que deve ser implementado em relação a essa população vulnerável. A proposta é que ocorra um processo de inclusão social em que a opinião e a ação dos sujeitos sejam levadas em consideração.

A inclusão social dos trabalhadores informais deve ser no trabalho decente - o que implica ter proteção legal, direitos trabalhistas e previdenciários, remuneração adequada, garantias de condições de saúde e de segurança no trabalho e respeito nas relações de trabalho. A dignidade do trabalhador deve ser respeitada, muito além das metas de produção e dos lucros das empresas e negócios em geral. 
A eficácia das políticas públicas ${ }^{415}$ voltadas a esse segmento da população é alvo de críticas e controvérsias. Sem tirar o mérito das inúmeras iniciativas de inclusão para a formalidade, de combate à desigualdade social, precisamos questionar o modelo de desenvolvimento econômico e social e o papel do Estado. Vivemos numa "sociedade salarial incompleta", desde sempre, e possuímos uma "cidadania regulada" pelo trabalho formal. Nesse contexto, encontramos uma grande porcentagem de brasileiros que vivem em condições precárias, sem qualquer proteção, na pobreza e na miséria.

Um dos grandes dilemas do século XXI é a questão do emprego, do trabalho e do meio ambiente. Vivemos uma contradição social cada vez mais vital. Os empregos se reduzem, aumentando os índices de desemprego, de empobrecimento e de miserabilidades social ${ }^{416}$. Mais de 1,2 bilhão de trabalhadores no mundo estão vivendo, com suas famílias, na pobreza. Além disso, 620 milhões vivem na extrema pobreza, isto é, com menos que US\$ 1,25 por dia ${ }^{417}$. Em resposta a essa situação, o capitalismo global e suas transnacionais recuperam os níveis de crescimento econômico, utilizandose de inúmeras formas de trabalho precário, da informalidade, da intensificação do trabalho e da superexploração da mão-de-obra.

É importante mantermos os ideais de um "Estado de Bem Estar completo" e de uma sociedade civil mais participativa e solidária nas questões públicas. Nesse sentido, pensamos em um modelo de desenvolvimento em que sejam considerados os interesses sociais e a defesa do meio ambiente. A prioridade devem ser os investimentos na educação, em primeiro lugar. Com uma educação básica, fundamental e média de qualidade, podemos vislumbrar um desenvolvimento com inclusão social. Os direitos

415 Organização Internacional do Trabalho (OIT) (2009). A agenda do Trabalho Decente e a economia informal. Políticas para facilitar a transição para a formalidade. Seminário Tripartite "A economia informal no Brasil: políticas para facilitar a transição para a formalidade”. Brasília, 12 e 13 de maio de 2009. www.oitbrasil.org.br. Consulta realizada em: 17/09/2009.

416 ANTUNES, Ricardo (2009).

417 International Labour Office (ILO) (2009). Global Employment Trends - Update. Geneve, may, p. 5. 
de cidadania se traduzem em ter acesso à educação, aos serviços de saúde, ao trabalho decente e à segurança, entre outras necessidades.

Sem igualdade social, o crescimento econômico não pode ser sustentável. Se não se ampliarem a todos os cidadãos as oportunidades reais disponíveis, os mercados trabalharão unicamente para as elites. A desigualdade social deve ser combatida através do compromisso do Estado com as camadas menos privilegiadas da sociedade e com o desenvolvimento sustentável. Apesar das dificuldades em identificar estratégias para alcançar tanto o desenvolvimento, como a liberdade para os indivíduos, num contexto de tamanha desigualdade e pobreza existentes entre o povo brasileiro, é fundamental continuarmos buscando meios de tornar um mundo melhor para todos. 


\section{REFERÊNCIAS BIBLIOGRÁFICAS}

ABRAMO, Laís. Desafios atuais da Sociologia do trabalho na América Latina: algumas hipóteses para a discussão. Buenos Aires, CLACSO (http://bibliotecavirtual.clacso.org.ar/ar/libros/cyg/ytabajo/abramo.rtf).

ALVES, Maria Aparecida \& TAVARES, Maria Augusta (2006). A DUPLA FACE DA INFORMALIDADE DO TRABALHO: "autonomia" ou "precarização". IN: ANTUNES, Ricardo (organizador). Riqueza e Miséria do Trabalho no Brasil. São Paulo: Boitempo.

ANTUNES, Ricardo (2009). Os dilemas do trabalho no limiar do século 21. CULT, $\mathrm{n}^{\mathrm{o}} 139$, Ano 12.

ANTUNES, Ricardo (2003). A nova morfologia do trabalho e o desenho multifacetado das ações coletivas. In, Marco Aurélio Santana e José Ricardo Ramalho (organizadores). Além da Fábrica - trabalhadores, sindicatos e a nova questão social. São Paulo: Boitempo, pp. 213 -224.

ANTUNES, Ricardo (organizador) (2006). Riqueza e miséria do trabalho no Brasil. São Paulo: Boitempo, 528 p.

ANTUNES, Ricardo (1999). Os Sentidos do Trabalho. Ensaio sobre afirmação e a negação do trabalho. Boitempo Editorial, São Paulo.

ARBACHE, Jorge Saba (2003). Pobreza e Mercados no Brasil. IN: CEPAL. Pobreza e Mercados no Brasil: uma análise de iniciativas de políticas públicas. Brasília, CEPAL, Brasil pp.9-62.

BOURDIEU, Pierre (2003). Compreender. In: BOURDIEU, P; com contribuições de A. Accardo et. al. A Miséria do mundo. Petrópolis, Rio de Janeiro: Vozes, p. 693. 
BOURDIEU, Pierre (2000). Las estructuras sociales de la economía. Barcelona, Ed. Anagrama, 2003.

BOURDIEU, Pierre (1983). Esboço de uma teoria prática. In: ORTIZ, Renato (org.). Pierre Bourdieu: Sociologia. São Paulo: Ática, Grandes cientistas sociais; 39.

BRANDÃO, Iracema (2002). Família, Mercado de Trabalho e Estratégias no Meio Urbano. Caderno CRH, Salvador, no 37, pp. 235-252, julho/dezembro.

BRUSCHINI, Cristina (2007). Trabalho e Gênero no Brasil nos últimos dez anos. Caderno de Pesquisa, v. 37, n. 132, p.537-572, set./dez.

BRUSCHINI, Cristina (2006). "Trabalho doméstico: inatividade econômica ou trabalho não remunerado?” R. Bras. Est. Pop., São Paulo, v. 23, n. 2, jul./dez.

BRUSCHINI, Cristina (2000). "Gênero e trabalho no Brasil: novas conquistas ou persistência da dominação?” (Brasil, 1985/95). In: ROCHA, M. I. B. (org.). Trabalho e gênero: mudanças, permanências e desafios. São Paulo: Abep, Nepo/Unicamp, Cedeplar/UFMG, Editora 34, pp. 13-58.

BRUSCHINI, Cristina (1998). "Fazendo as perguntas certas: como tornar visível a contribuição econômica das mulheres para a sociedade?" IN: ABRAMO, L.; ABREU, A. R. P. (Orgs.). Gênero e trabalho na Sociologia latino-americana. São Paulo, Rio de Janeiro: Alast, p. 277-294 (Série II Congresso Latino-Americano de Sociologia do Trabalho).

BRUSCHINI, Cristina (1994). "Trabalho feminino: trajetória de um tema, perspectiva para o futuro". Revista Estudos Feministas, v.2, n.3, p.17-32.

CACCIAMALI, Maria Cristina (2002). Princípio e Direitos Fundamentais no Trabalho na América Latina. São Paulo em Perspectiva, vol. 16, $\mathrm{n}^{\mathrm{o}}$ 2, São Paulo, Abril/Junho. 
CACCIAMALI, Maria Cristina C. \& BRAGA, T. (2002). "Educação e Trabalho da População Jovem - Diagnóstico e Políticas". IN: Estudos e análises com vistas à definição de políticas, programas e projetos relativos ao mercado de trabalho brasileiro, tema 18. Ministério do Trabalho e Emprego e Fundação Instituto de Pesquisas Econômicas (FIPE), São Paulo.

CACCIAMALI, Maria Cristina (2000). Globalização e Processo de Informalidade. Economia e Sociedade. Campinas: Unicamp. I.E., nº 14, pp. 152-174, junho.

CACCIAMALI, Maria Cristina (2000). As economias informal e submersa: conceitos e Distribuição de renda. IN: José Márcio Camargo, Fabio Giambiagi (orgs). Distribuição de renda no Brasil. Rio de Janeiro: Paz e Terra, IERJ, $2^{\circ}$ edição.

CAMARANO, Ana Amélia (2001). O Idoso Brasileiro no Mercado de Trabalho. Texto para Discussão, $\mathrm{n}^{\circ}$ 830, Rio de Janeiro: IPEA.

CAMARANO, Ana Amélia et al.(1999). Como vai o idoso brasileiro?. Texto Para Discussão, n 681, Rio de Janeiro: Instituto de Pesquisa Econômica Aplicada(IPEA).

CARDOSO, Adalberto Moreira.; COMIN, Álvaro Augusto e GUIMARÃES, Nadya Araújo (2006). Os deserdados da indústria: reestruturação produtiva e trajetórias intersetoriais de trabalhadores demitidos da indústria brasileira. In: GUIMARÃES, N; HIRATA, H. (orgs.). Desemprego: trajetórias, identidades, mobilizações. São Paulo, Editora SENAC, Série Trabalho e Sociedade.

CARDOSO, Eduardo Schiavone (2001). Pescadores Artesanais: natureza, território, movimento social. Tese apresentada junto ao Programa de Pós Graduação em Geografia Física da Faculdade de Filosofia, Letras e Ciências Humanas da Universidade de São Paulo.

CARNEIRO, Sergio. A. M. (2000). Trabalho e Violência: Relação de Proximidade Violência a trabalhadores durante jornada de trabalho, na zona norte de São Paulo, em 1998. Dissertação de Mestrado apresentada ao Departamento de Saúde Ambiental da Faculdade de Saúde Pública da Universidade de São Paulo. 
CASTEL, Robert (2004). As transformações da questão social. In: CASTEL, Robert et alli (orgs). Desigualdade e a questão social. São Paulo: EDUC, $2^{\circ}$ edição, versão ampliada.

CASTEL, Robert (2004). As armadilhas da exclusão. In: CASTEL, Robert et alli (orgs). Desigualdade e a questão social. São Paulo: EDUC, $2^{\circ}$ edição, versão ampliada.

CASTEL, Robert (1998). As metamorfoses da questão social: uma crônica do salário. Petrópolis, Editora Vozes.

CASTRO, Nadya e DEDECCA, Cláudio ( 1998). Flexibilidade e Precarização: Tempos mais Duros. In: CASTRO, Nadya e DEDECCA, Cláudio (orgs). A Ocupação na América Latina: Tempos mais duros. São Paulo, ALAST.

CECEÑA MARTORELLA, Ana Ester (1996). "Los Miserables em la Teoria Social Latinoamericana".IN: MARINI, Ruy Mauro e Millán, MÀRGARA (org.) La Teoria Social Latinoamericana. México, UMA, Tomo II, pp. 237-262.

CERQUEIRA, Monique Borba ( 2000). Os Guardiões do Tempo Sobrevivem à Cidade Veloz. Trabalho Informal e Saúde. Dimensões da Exclusão Social. Dissertação de Mestrado. Departamento de Sociologia do Instituto de Filosofia e Ciências Humanas da Universidade Estadual de Campinas, Campinas/SP.

CHESNAIS, François (1996). A mundialização do capital. São Paulo: Xamã Editora.

COHN, Amélia.; HIRANO, Sedi.; SATO, Ademir K. \& KARSCH, Ursula S. (1985). Acidentes do trabalho: uma forma de violência. São Paulo: CEDEC/Brasiliense, 160p.

COMIN, Álvaro A. (2003). Migrações entre formal e informal: um survey com trabalhadores. Série Estudos e Pesquisas.Salvador - Bahia, volume 66, p. 63-78.

COMIN, Álvaro A. (2003). Mudança na estrutura ocupacional do mercado e trabalho em São Paulo. Tese apresentada ao Programa de Pós-Graduação em 
Sociologia da Faculdade de Filosofia, Letras e Ciências Humanas da Universidade de São Paulo.

CORAGGIO, José Luis. Del Sector Informal e La Economia Popular. Nueva Sociedad, pp. $118-131$

COSTA, Márcia Regina da (1981). As vítimas do capital: os acidentados do trabalho. Rio de Janeiro: Achiamé.

CUT (2000). Mapa do Trabalho Informal do Município de São Paulo. São Paulo.

DALL'OCA; Aidar Wagner. (2003). Diagnose da Entidades Envolvidas com a Pesca Profissional no Estado do Mato Grosso do Sul. Revista Brasileira de Saúde Ocupacional, São Paulo, 27(103/104), 103-116;

DEDECCA, Cláudio. Salvadori.; RIBEIRO, Camila Santos Matos de Freitas; ISHII, Fernando Hajime (2008). Ocupação e Tempo de trabalho. IN: XVI Encontro Nacional de Estudos Populacionais, Caxambu, São Paulo.

DEDECCA, Cláudio. Salvadori. (2008), "Regimes de trabalho, Uso do tempo e Desigualdade entre Homens e Mulheres”. In: COSTA, A. O.; SORJ, B.; BRUSCHINI, C.; Hirata, H. (org.). Mercado de Trabalho e Gênero: Comparações Internacionais. Rio de Janeiro: FGV, v. 1, p. 279-298.

DEJOURS, Christophe (1999). A banalização da injustiça social. Rio de Janeiro: Editora Fundação Getulio Vargas, 160 p..

DEJOURS, Christophe (1987). A loucura do trabalho: estudo de psicopatologia do trabalho. São Paulo: OBORÉ Editorial.

DEMAZIÈRE, Didier; DUBAR, Claude. (2006) . Trajetórias profissionais e formas identitárias: uma teorização. In: GUIMARÃES, Nadya Araújo; HIRATA, Helena. (orgs.). Desemprego: trajetórias, identidades, mobilizações. São Paulo: Editora SENAC, Série Trabalho e Sociedade. 
DIAS, Elizabeth Costa (2002). Setor informal de trabalho: um novo-velho desafio para a saúde do trabalhador. In: SALIM Celso Amorin; CARVALHO, Luiz Fernando de (organizadores). Saúde e segurança no ambiente de trabalho: contextos e vertentes. Belo Horizonte: FUNDACENTRO, Universidade Federal de São João Del Rei, p. 15168.

DUBAR, Claude (1998). Trajetórias sociais e formas identitárias: alguns esclarecimentos conceituais e metodológicos. Educação e Sociedade, vol. 19, nº 62, Campinas; Apr..

DURKHEIM, Émile. (1995). Da divisão do trabalho social. São Paulo: Editora Martins Fontes.

ESTEnSSORO, Luís (2003). Capitalismo, Desigualdade e Pobreza na América Latina. Tese de Doutorado pelo Programa de Pós-Graduação do Departamento de Sociologia da Faculdade de Filosofia, Letras e Ciências Humanas (FFLCH) da Universidade de São Paulo (USP).

FASSIN, Didier (1996). Exclusion, underclass, marginalidad”. Revie Française de Sociologie, XXXVII,pp. $37-75$.

GOFFMAN, Erving. 1988. Estigma: nota sobre a manipulação da identidade deteriorada. Rio de Janeiro: Guanabara Koogan.

GUIMARÃES, Nadya Araújo e HIRATA, Helena (org.) (2006). Desemprego. Trajetórias, identidades, mobilizações. São Paulo: Editora SENAC, São Paulo

GUIMARÃES, Nadya Araújo (2005). “Trabalho: uma categoria-chave no imaginário juvenil?”. In: ABRAMO, Helena Wendel; BRANCO, P. P. M. Retratos da Juventude Brasileira. São Paulo: Instituto Cidadania; Editora Fundação Perseu Abramo,PP. 149174. 
GUIMARÃES, Nadya Araújo (2006). Trajetórias inseguras, autonomização incerta: os jovens e o trabalho em mercados sob intensas transições ocupacionais. In: Transição para vida adulta ou vida adulta em transição?. Rio de Janeiro: IPEA,.

GUIMARÃES, Nadya Araújo (2004). CAMINHOS CRUZADOS. Estratégias de empresas e trajetórias de trabalhadores. São Paulo: USP, Curso de Pós-Graduação em Sociologia: Ed. 34.

GUIMARÃES, Nadya Araújo (2003). Por uma sociologia do desemprego; contextos societais, construções normativas e experiências subjetivas. In: Marco Aurélio Santana e José Ricardo Ramalho (organizadores). Além da Fábrica - trabalhadores, sindicatos e a nova questão social. São Paulo: Boitempo, pp. 213 -224.

GUIMARÃES, Nadya Araújo (2002). Por uma Sociologia do Desemprego. Revista Brasileira Ciências Sociais, n. 17, nº 50, São Paulo, outubro.

GUIMARÃES, Nadya Araújo (2001). "Laboriosas mas redundantes: gênero e mobilidade no trabalho no Brasil dos 90”. Estudos Feministas, $2^{\circ}$ semestre, ano 9.

HIRANO, Sedi (2004). Capitalismos Mundiais, Desigualdade Social e a América Latina. China em Estudo, nº 6, (Publicação do Departamento de Letras Orientais da Faculdade de Filosofia, Letras e Ciências Humanas da Universidade de São Paulo).

HIRANO, Sedi. \& ESTENSSORO, Luís. (2006). Padrões de Desenvolvimento e de Oportunidade Social na América Latina e no Leste Asiático. Cadernos PROLAM/USP, Ano 5, vol. 2.

HIRANO, Sedi et alli (1990). A cidadania do trabalhador acidentado: (re)conhecimento do direito aos direitos sociais. Tempo Social; Revista Sociol. USP, São Paulo 2(1): $127-150,1^{\circ}$ semestre.

HIRATA, Helena\& KERGOAT, Danièle (2007). "Novas Configurações da Divisão Sexual do Trabalho". Cadernos de Pesquisa, v. 37, n. 132, p. 595-609, set./dez.. 
HIRATA, Helena (2002). Nova divisão sexual do trabalho? Um olhar voltado para a empresa e a sociedade. São Paulo: Boitempo, Coleção Mundo do Trabalho.

HIRATA, Helena (2001/02). "Globalização e divisão sexual do trabalho”. Cadernos Pagu, n. 17/18, pp. 139-156.

HIRATA, Helena; HUMPHREY, John (1989). Trabalhadores Desempregados: trajetórias de operárias e operários industriais no Brasil. RBCS, ${ }^{\circ}$ 11, vol. 4, outubro.

IANNI, Octavio.(2001). A Era do Globalismo. Rio de Janeiro, Civilização Brasileira, pp. $215-235$.

IANNI, Octavio.(1988). O Imperialismo na América Latina. Rio de Janeiro, Civilização Brasileira.

IBANHES, Lauro César (1999). O Setor Informal Urbano : a Organização e as Condições de Saúde de um Grupo de Vendedores Ambulantes. Tese de Doutorado. Programa de Pós-Graduação em Saúde Pública, Departamento de Prática de Saúde Pública, Faculdade de Saúde Pública da Universidade de São Paulo.

INTERNATIONAL LABOUR OFFICE (ILO) (2009). Global Employment Trends Update. Geneve, may

INSTITUTO BRASILEIRO DE GEOGRAFIA E ESTATÍSTICA (IBGE) (2008). Algumas características da inserção das mulheres no mercado de trabalho -Recife, Salvador, Belo Horizonte, Rio de Janeiro, São Paulo e Porto Alegre- 2003 - 2008. Pesquisa Mensal de Emprego, Rio de Janeiro.

INSTITUTO BRASILEIRO DE GEOGRAFIA E ESTATÍSTICA (IBGE) (2002). Perfil dos Idosos Responsáveis pelos Domicílios no Brasil, 2000. Estudos \& Pesquisas, $\mathrm{n}^{\circ}$ 9, Rio de Janeiro.

INSTITUTO DE PESQUISA ECONÔMICA APLICADA (IPEA) (2006). Brasil: o estado de uma nação - mercado de trabalho, emprego e informalidade. Rio de Janeiro. 
JOSÉ-SILVA, Maria de Fátima (2006). Para onde vamos? A saúde física e mental de ex-empregados do mercado de trabalho formal, do ramo de metalurgia, que se encontram empregados/ocupados na informalidade. Um estudo comparativo entre Brasil e Argentina. Tese de Doutorado, Programa de Pós-Graduação em Integração da América Latina - PROLAM, Universidade de São Paulo;

KOWARICK, Lúcio (1975). Capitalismo e Marginalidade na América Latina. Rio de Janeiro, Ed. Paz e Terra.

LIMA, Jacob Carlos \& CONSERVA, Marinalva de Sousa (2006). Redes Sociais e Mercado de Trabalho: entre o Formal e o Informal. POLÌTICA e TRABALHO. Revista de Ciências Sociais, nº 24 Abril, pp. 73-98.

LIMA, Jacob C. e Soares, Maria José Bezerra Soares. Trabalho flexível e o novo informal. Caderno CRH, 37, jul-dez 2002.

LOWENSON, R. Health Impact of Occupational Risks in the Informal Sector in Zimbabwe (1998). International Journal Environment and Occupational Health, 4 (4): 264-274.

MACHADO, Jorge Mesquita Huet e GOMEZ, Carlos Minayo (1994). Acidente de trabalho: uma expressão da violência social. Cadernos de Saúde Pública; 10 (supl.1): 74-87.

MADEIRA, F. R. (1993). Pobreza, Escola e Trabalho: convicções virtuosas, conexões viciosas. São Paulo em Perspectiva, 7(1): 70-83, janeiro/março.

MALAGUTI, Manoel Luiz ( 2000). Crítica à razão informal: a imaterialidade do salariado. São Paulo: Boitempo; Vitória: EDUFES, 173p.

MARINI, Ruy Mauro (2000). Dialética da Dependência. Petrópolis: Editora Vozes. 
MARSHALL, Thomas Humphrey (1967). Cidadania, Classe Social e Status. Rio de Janeiro: Zahar Editores, p.76.

MARTINS, Heloisa Helena Teixeira de Souza (2004). A DIFÍCIL TRANSIÇÃO. Análise das trajetórias ocupacionais de jovens operários metalúrgicos. In: Ladislau Dowbor et alli. (orgs). Desafios do trabalho. Petrópolis, Rio de Janeiro: Ed. Vozes, pp. 169-186.

MARTINS, Heloisa Helena Teixeira de Souza (2000). “A juventude no contexto da reestruturação produtiva". In: ABRAMO, H. W.; FREITAS, M. V.; SPÓSITO, M. P. (org.). Juventude em Debate, São Paulo: Cortez.

MARTINS, Heloisa Helena Teixeira de Souza (1997). "O jovem no mercado de trabalho. Juventude e contemporaneidade". Revista Brasileira de Educação, São Paulo, n 5/6, p. 96-109, maio-agosto/setembro-dezembro, Edição Especial.

MARTINS, José de Souza (1997). Exclusão social e a nova desigualdade. São Paulo: Paulus.

MARX, Karl (1988). O Capital. São Paulo, Nova Cultural, Livro Primeiro, Seção VII, Caps. XXI a XXV.

MARX, Karl. (1978). O 18 do Brumário e Cartas a kugelmann. Rio de Janeiro, Ed. Paz e Terra.

MATSUO, Myrian (2006). Death from external causes - Recent evolution and the need for change of focus. OSH \& Development, $\mathrm{n}^{\circ}$ 8, Swedish Association for Occupational and Environmental health \& Development (UFA) December.

MATSUO, Myrian (1997). Acidentado do Trabalho: Reabilitação ou Exclusão? Dissertação (Mestrado), Universidade de S. Paulo (USP). Faculdade de Filosofia, Letras e Ciências Humanas. Pós-Graduação em Sociologia. Orientador: Prof. Dr. Sedi Hirano. 
MATSUO, Myrian (1998). Acidentado do Trabalho: Reabilitação e Exclusão? Fundacentro/Ministério do Trabalho e Emprego.

MELO, Hildete Pereira de \& TELES, JORGE, Luiz Teles (2000). Serviços e Informalidade: o comércio ambulante no Rio de Janeiro. Texto para Discussão $\mathrm{n}^{\circ}$ 773, IPEA (Instituto de Pesquisa Econômica Aplicada), Rio de Janeiro, dezembro.

MENDES, René \& CAMPOS, Ana Cristina Castro (2004). Saúde e Segurança no Trabalho Informal: Desafios e Oportunidades para a Indústria Brasileira. Rev. Bras. Med. Trab.; Belo Horizonte, vol.2, nº 3, jul - set. p. 209-223.

MENEZES FILHO, Naércio; MENDES, Marcos; ALMEIDA, Eduardo (2004). O Diferencial de salários formal-informal no Brasil: segmentação ou viés de seleção? RBE, Rio de Janeiro, 58(2), abril-junho, pp. 235-248.

MINISTÉRIO DO TRABALHO E EMPREGO (MTE)(2006). ATLAS DA ECONOMIA SOLIDÁRIA NO BRASIL. Secretaria Nacional de Economia Solidária. Brasília.

NAVARRO, Vera Lúcia (2003). O trabalho e a saúde do trabalhador na indústria de calçados. São Paulo em Perspectiva, 17 (2): 32-41.

NAVARRO, Vera Lúcia (1998). A produção de calçados de couro em Franca (SP): a reestruturação produtiva e seus impactos sobre o trabalho. Tese de Doutorado. Araraquara: Faculdade de Ciências e Letras da UNESP;

NERI, Marcelo (2006). Informalidade. Ensaios Econômicos, nº 635, Escola de Pós Graduação em Economia da Fundação Getúlio Vargas, Dezembro.

NERI, Marcelo (2005). Análise dos Negócios Nanicos a partir de Pesquisa. Economia Informal Urbana - ECINF. Texto para Discussão, nº 01, agosto, 2005, SEBRAE (Serviço Brasileiro de apoio às Micro e Pequenas Empresas) 
NEVES, Magda; JAYME, Juliana; ZAMBELLI, Paulina (2006). Trabalho e cidade: os camelôs e a construção dos shoppings populares em Belo Horizonte. Paper apresentado no $30^{\circ}$ Encontro Anual da ANPOCS; Caxambu/Minas Gerais; 24 a 28 de outubro.

NORONHA, Eduardo G. (2003).“Informal”, ilegal, injusto: percepções do mercado de trabalho no Brasil. Revista Brasileira de Ciências Sociais, v. 18, n. 53, São Paulo, outubro.

NUN, José (1999). El Futuro del Empleo y la Tesis de la Masa Marginal. Desarrollo Econômico, vol. 38, $\mathrm{n}^{\mathrm{o}}$ 152, jan-mar.

NUNES, Christiane Girard Ferreira \& Mário Theodoro (2006). Work and Health in the informal sector: Domestic work and street commerce. OSH \& Development, Swedish, No 8, December.

ORGANIZAÇÃO INTERNACIONAL DO TRABALHO (OIT) (2009). A agenda do Trabalho Decente e a economia informal. Políticas para facilitar a transição para a formalidade. Seminário Tripartite "A economia informal no Brasil: políticas para facilitar a transição para a formalidade”. Brasília, 12 e 13 de maio de 2009.

ORGANIZAÇÃO INTERNACIONAL DO TRABALHO (OIT) (2009). Panorama laboral para América Latina e Caribe. Janeiro de 2009

ORGANIZAÇÃO INTERNACIONAL DO TRABALHO (OIT) (1972). Employment, Income and Equality: A Strategy for Increasing Productive Employment in Kenya. Genebra.

OLIVEIRA, Francisco de (2003). Crítica da razão dualista. O ornitorrinco. São Paulo: Boitempo Editorial.

OLIVEIRA, Luiz Paulo Jesus de (2005). A condição "provisória-permanente" dos trabalhadores informais: 0 caso dos trabalhadores de rua na cidade de Salvador. Dissertação de Mestrado apresentada ao Programa de Pos-Graduação em 
Ciências Sociais na Faculdade de Filosofia e Ciências Humanas, Universidade Federal da Bahia.

ORTIZ, Renato (org.). Pierre Bourdieu: sociologia. São Paulo: Ática, Grandes cientistas sociais.

PAOLI, Maria Célia (1989). Trabalho e Cidadania. Experiência do Mundo Público da História do Brasil Moderno. Revista de Estudos Avançados, vol. 3, nº 7, pp. 40-66.

PEIXOTO, Clarice (2004). Aposentadoria: retorno ao trabalho e solidariedade familiar. In: PEIXOTO, Clarice (org.). Família e Envelhecimento. Rio de Janeiro: FGV, 2004, pp. 57-84., p. 60.

PERES, Marcos Augusto de Castro. (2007). Velhice, Trabalho e Cidadania: as políticas da terceira idade e a resistência dos trabalhadores idosos à exclusão social. Tese de Doutorado em Educação. Faculdade de Educação da Universidade de São Paulo, São Paulo, 2007, 361p.

PERES, Marcos Augusto de Castro (2002). Trabalho, idade e exclusão: a cultura organizacional e as imagens sobre o envelhecimento. Dissertação (Mestrado em Sociologia). Instituto de Filosofia e Ciências Humanas, Universidade de Campinas.

PINTO, Aníbal (2000). Natureza e Implicações da Heterogeneidade Estrutural na América Latina. IN: BIELSCHOWSKY, Ricardo (org). Cinquenta anos de pensamento na CEPAL. Rio de Janeiro, Record, pp. 569 -588.

POCHMANN, Márcio (2005). Economia do Microempreendimento Informal no Brasil. Texto para Discussão $n^{0}$ 02. SEBRAE (Serviço Brasileiro de Apoio às Micro e Pequenas Empresas). Brasília/DF.

POCHMANN, Márcio (2001). O Emprego na Globalização. São Paulo: Boitempo Ed. 
POCHMANN, Márcio( 2000). “O Excedente de mão-de-obra no Município de São Paulo". In: CUT, Mapa do Trabalho Informal do Município de São Paulo. São Paulo, CUT, pp. 11-18.

POCHMANN, Márcio. (1998). A inserção ocupacional e os empregos dos jovens. São Paulo: Associação Brasileira de Estudos do Trabalho.

PRANDI, José Reginaldo (1978). O Trabalhador por conta própria sob o Capital. São Paulo: Edições Símbolo.

QUiJano, Aníbal (1998). La Economia Popular y sus Caminos em América Latina. Lima Mosca Azul.

QUINLAN, M; MAYHEW, C. \& BOHLE, P. (2001). The global expansion of precarious employment, work disorganization, and consequences for occupational health: a review of recent research. International Journal of Health Services, 31:335413.

RAMALHO, José Ricardo ( 2000). Trabalho e Sindicato: Posições em Debate na Sociologia Hoje. Dados, vol. 43. nº 4.

REIS JUNIOR, F. A. (2003). Pesca da lagosta com o uso de compressor: os riscos do trabalho em condições hiperbáricas. Paper apresentado no 27th International Congress on Occupational Health (ICOH) - Foz de Iguaçu, Brasil,

RIBEIRO, Herval Pina (1994). O número de acidentes de trabalho no Brasil continua caindo: sonegação ou realidade? SOS - Revista da Associação Brasileira para Prevenção de Acidentes, Ano XIX, março/abril de 1994.

ROCHA, Sonia (2008). “A inserção dos jovens no mercado de trabalho". Caderno CRH, Salvador, v. 21, n. 54, set./dez. 
RODRIGUES, Leôncio Martins (1986). A Cidadania do Trabalhador Urbano. In: TEIXEIRA, João Gabriel Lima Cruz. A construção da cidadania. Brasília: Editora Universidade de Brasília.

ROSANVALLON, Pierre (1998). A nova questão social: repensando o EstadoProvidência. Brasília: Instituto Teotônio Vilela.

ROSANVALLON, Pierre (1997). A crise do Estado-Providência. Goiânia: UFG.

ROSENBLUTH, Guillermo (1994). Informalidad y Pobreza em América Latina. Revista de la CEPAL, no ${ }^{\circ}$ 2, abril.

SADER, Eder (1988). Quando novos personagens entraram em cena. São Paulo: Ed. Paz e Terra, 329p.

SANTOS, Wanderley Guilherme dos (1979). Cidadania e Justiça: a política social na ordem brasileira. Rio de Janeiro: Ed. Campus.

SECRETARIA ESPECIAL DE AQUICULTURA E PESCA - SEAP (2007). Saúde e Segurança do Pescador. Série Formação e Valorização do Pescador.

SEN, Amartya (2000). Desenvolvimento como liberdade. São Paulo: Companhia das Letras.

SENA, Ana Laura. 2002. O trabalho informal nas ruas e praças de Belém: estudo sobre o comércio ambulante de produtos alimentícios. Belém: NAEA (Núcleo de Altos Estudos Amazônicos)/ UFPA.

SILVA, Josué Pereira da (2008). Trabalho, cidadania e reconhecimento. São Paulo: Annablume.

SINGER, Paul (1997). Social Exclusion in Brasil. OIT, Labour Institutions and Development Programme, DP/94/1997. 
SINGER, Paul (1996). Desemprego e Exclusão Social. São Paulo em Perspectiva, vol. $10, \mathrm{n}^{\mathrm{o}} 1$, jan-mar, pp. 3-13.

SINGER, Paul (1973). "Urbanização, Dependência e Marginalidade na América Latina". IN: SINGER, Paul. Economia Política da Urbanização. São Paulo, Brasiliense, pp. 63-90.

SORJ, Bila (2004). "Trabalho remunerado e trabalho não-remunerado". IN: OLIVEIRA, S. de; RECAMÁN, M. VENTURI, G. A Mulher brasileira nos espaço público e privado. São Paulo: Editora Fundação Perseu Abramo, p.107-119.

SOTO de, Hernando (1987). El outro Sendero: la revolucion informal. Buenos Aires: Editorial Sudamericana, $3^{\circ}$ edição.

TAVARES, Maria Augusta (2004). Os fios (in)visíveis da produção capitalista: informalidade e precarização do trabalho. São Paulo: Cortez.

TELLES, Vera da Silva (1996). Questão Social: afinal do que se trata?. São Paulo em Perspectiva, 10(4).

TELLES, Vera da Silva (1992). Cidadania inexistente: incivilidade e pobreza; um estudo sobre trabalho e família na grande São Paulo. Tese de Doutorado. Faculdade de Filosofia, Letras e Ciências Humanas da Universidade de São Paulo, 335 pp.

THEODORO, Mario (2002). O Estado e os Diferentes Enfoques sobre o Informal. Brasília, IPEA, novembro de 2002, Texto para Discussão nº 919.

TOKMAN, Victor E (2001). De la informalidad a la modernidad. Santiago, Oficina Internacional Del Trabajo, Organización Internacional Del Trabajo.

WAJNMAN, Simone et alli. (2004). Os idosos no mercado de trabalho de trabalho: tendências e conseqüências. In: CAMARANO, Ana Amélia (org.). Os novos idosos brasileiros: muito além dos 60? Rio de Janeiro: Instituto de Pesquisa Econômica Aplicada (IPEA). 
WÜNSCH FILHO, Victor (1999). Reestruturação produtiva e acidentes de trabalho no Brasil: estrutura e tendências. Caderno Saúde Pública, v. 15, $\mathrm{n}^{\mathrm{o}}$ 1, Rio de Janeiro, janeiro/março.

\section{SITES CONSULTADOS}

$\underline{\text { www.capes.br }}$

$\underline{\text { www.cati.sp.gov.br }}$

$\underline{\text { www.dieese.org.br }}$

www.ensp.fiocruz.br

$\underline{\text { www.fundacentro.gov.br }}$

www.ibge.gov.br

www.ilo.org

$\underline{\text { www.ipea.gov.br }}$

www.mte.gov.br

www.mncr.org.br.

www.previdenciasocial.gov.br

www.oit.org.br

$\underline{\text { www.seade.gov.br }}$

$\underline{\text { www.sebrae.com.br }}$

www.unicamp.br

www.usp.br 